AL.2. $2005-45$

C. 2

Plant community types of sand dunes and sand plains in selected areas of the Boreal Natural Region

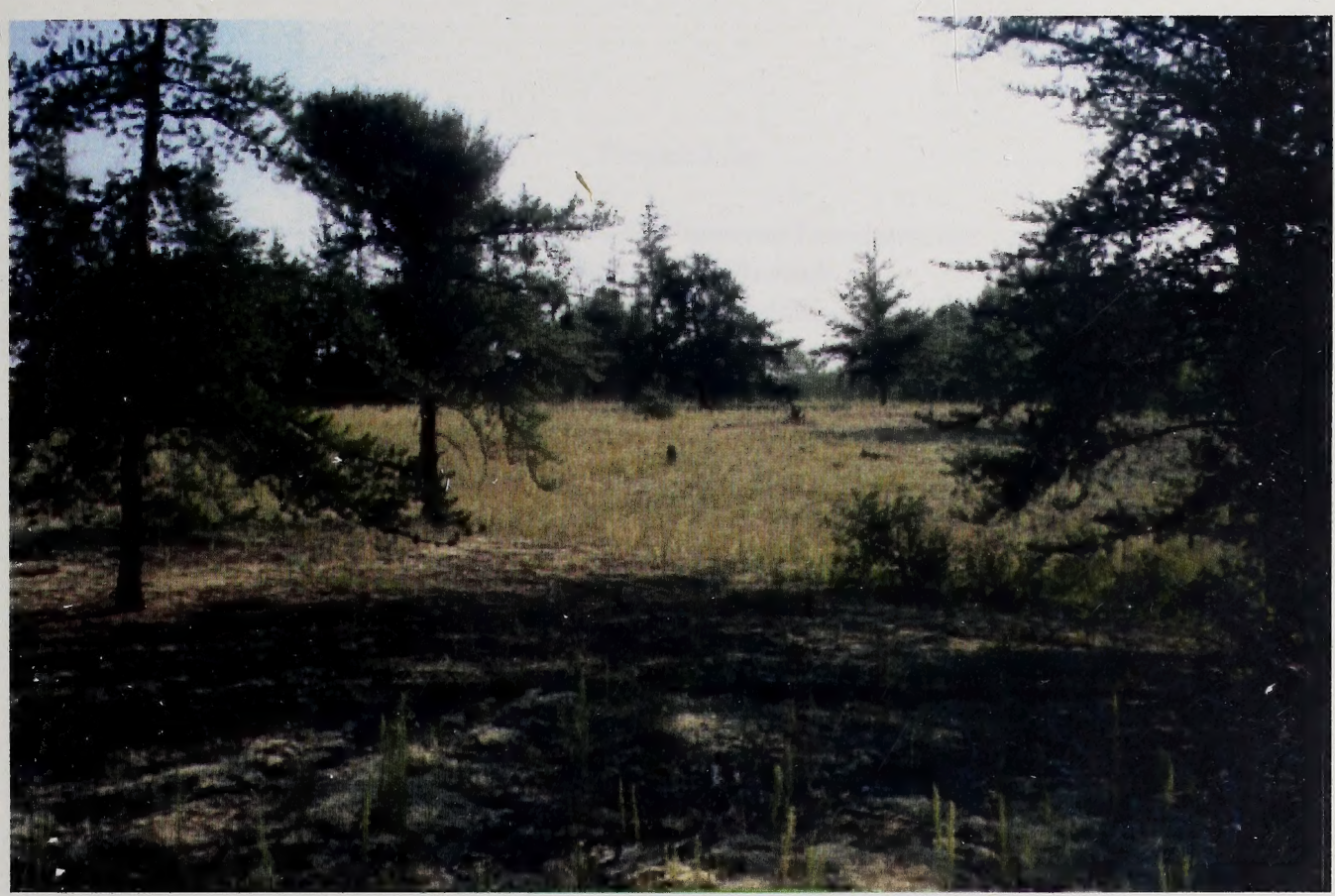


I

i

I

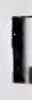

I

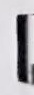

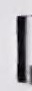

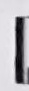

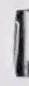

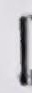

$\mid$ 


\title{
Plant community types of sand dunes and sand plains in selected areas of the Boreal Natural Region
}

Prepared for

\author{
Alberta Sustainable Resource Development \\ Resource Data Branch \\ Edmonton, Alberta
}

\author{
Prepared by \\ Wildlands Ecological Consulting Ltd. \\ \#60 Neal Close, Red Deer, Alberta T4P 1N4 \\ Office: (403) 346-1057 \\ Fax: (403) 346-3257
}

Cite publication as:

Riddell, R.N. 2005. Plant community types of sand dunes and sand plains in selected areas of the Boreal Natural Region. Prepared for Alberta Sustainable Resource Development, Resource Data Branch. Prepared by Wildlands Ecological Consulting Ltd., Red Deer Alberta. 
Digitized by the Internet Archive in 2016 


\section{Executive Summary}

The Alberta Natural Heritage Information Centre (ANHIC) inventories, monitors and disseminates information on biological diversity in Alberta. Detailed data regarding provincial flora, fauna and native plant communities are collected and tracking lists have been developed to monitor elements of biodiversity that are considered rare or have other special significance. Plant communities occurring in areas of unique landforms often support small patch communities that are not well documented in the province. Consequently, information gaps were identified concerning plant communities that inhabit eolian landforms in the boreal forests. Resource Data Branch of Alberta Sustainable Resource Development contracted Wildlands Ecological Consulting Ltd. to identify and inventory plant communities of the boreal sand dunes and sand plains in Holmes Crossing Sandhills Ecological Reserve and a proposed provincial park and natural area near North Buck Lake, Alberta. These sites were chosen as representative eolian landforms of the Boreal Central Mixedwood and Dry Boreal Mixedwood Natural Subregions, respectively.

Eolian landforms in the Holmes Crossing Sandhills Ecological Reserve are predominately a series of well preserved transverse sand dunes with associated parabolic sand dunes and a small section of sand plains. Upland vegetation here is mainly jack pine forest, scattered stands of aspen, black spruce, mixedwood, and small stands of paperbirch and white spruce. Lowland areas support stands of black spruce and tamarack sphagnum bogs. Interdune wetlands were dominated by sedge fens, dwarf birch and willow communities. In the Holmes Crossing Sandhills Ecological Reserve there were very few areas of open sand and no active sand dunes or blowouts were observed. The North Buck Lake study area is drier and is dominated by parabolic sand dunes with larger surface areas of exposed sand. Sand dunes in this study area were stabilised by a similar pattern of vegetation although soils were more xeric influencing plant communities. There is considerable ground disturbance in the North Buck Lake study area as a result of recreational off-road vehicle use. This has affected the vegetation especially in dry open habitats and has led to an increased area of exposed sand. In contrast, the Holmes Crossing Sandhills Ecological Reserve is well signed and most trailheads were blocked to vehicular access. However, there was some ground disturbance at trailheads and All Terrain Vehicle tracks were observed on several backcountry trails and seismic lines.

This study focused on the inventory of natural and semi-natural plant communities. Unique or recurring plant communities were identified in the field and inventoried using standard provincial ecological site and vegetation forms. The concepts for potential plant communities were first developed in the field by tabulating the percent ground cover of dominant species within each stratum for each stand sampled. This preliminary grouping of stands with similar characteristics helped to identify potential communities and to direct sampling efforts. A range of site positions and ecological conditions were investigated in search of unique or recurring plant communities. Field data was then analysed using PC-ORD (Version 4.25) to statistically determine grouping of plant communities using Detrended Correspondence Analysis and agglomerative cluster analysis. The results were critically reviewed and final plant communities were then classified according to The International Classification of Ecological Communities. Descriptive statistics were produced for each community and these were used to compare the community type to other documented types. Based on a literature review, ratings were assigned to reflect the degree of similarity between each type and the current classification.

A total of 64 detailed plots were completed including 32 in each study area. Data analysis resulted in the identification of 31 potential plant community types. These included 17 forest, 7 shrubland and 7 herbaceous vegetation types. There were 5 jack pine types, 1 white spruce, 4 black spruce, 1 tamarack, 4 aspen, and 2 white birch types identified. Shrubland types included 1 bog birch, 2 willow wetlands, 1 green alder, 2 bearberry, and 1 dwarf black spruce - tamarack type. Herbaceous vegetation types included 2 wet sedge fens, 1 bluejoint wet meadow, 1 fowl grass shoreline, 1 Rocky Mountain fescue - plains wormwood xeric opening, 1 hay sedge-poverty oat grass, and 1 slender wheat grass community. There was considerable diversity of plant communities observed during the study and it is recommended that additional sampling be conducted to search for additional plant communities. 



\section{Acknowledgements}

Wildlands Ecological Consulting Ltd. would like to thank Mr. Keith Ainsley of Resource Data Branch, Alberta Sustainable Resource Development (ASRD) for support and guidance. Ms. Lorna Allen of Community Development Department, Parks \& Protected Areas, ASRD, reviewed the final report. Mr. Ian Macdonald assisted with the collection of data at all plots, identification of the all vascular plants and plot summaries. Ms. Janet Marsh identified lichens and ephiphytes, and Ms. Jennifer Doubt identified unknown mosses. Ms. Lynne Wassick assisted with data entry and production of the final report. Mr. Rick Riddell of Wildlands Ecological was responsible for project management, field surveys and analysis, and the final report. Mr. Garry E. Hornbeck, M.Sc., P.Biol., of Wildlife \& Company Ltd., Calgary, Alberta, also reviewed the final report. 

Executive Summary

Acknowledgements

Table of Contents

List of Tables

List of Figures..

List of Plates .

List of Appendices

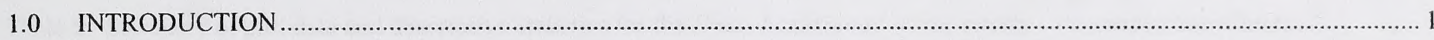

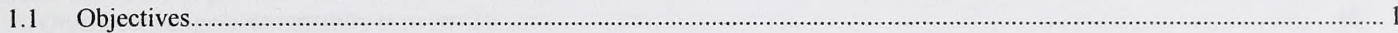

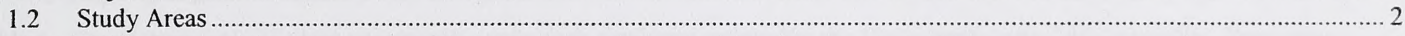

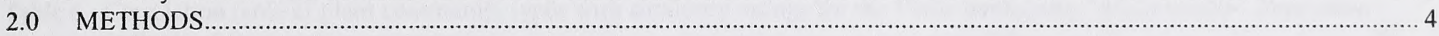

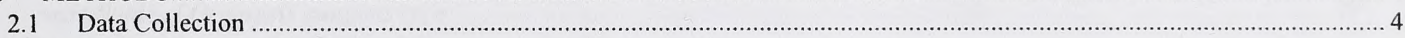

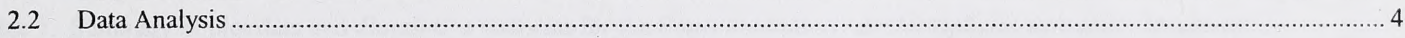

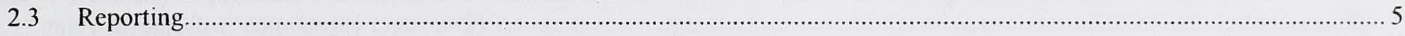

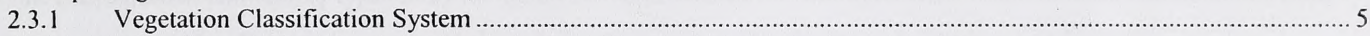

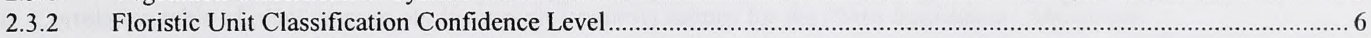

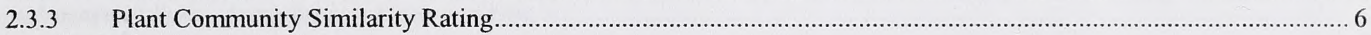

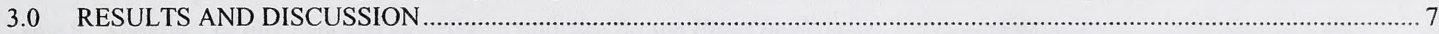

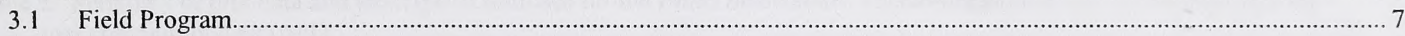

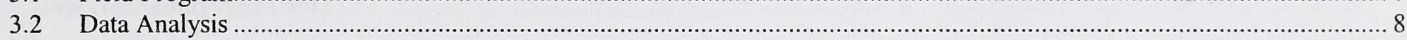

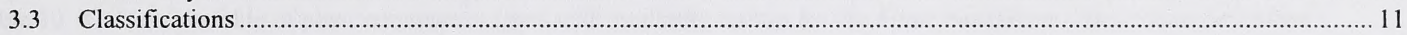

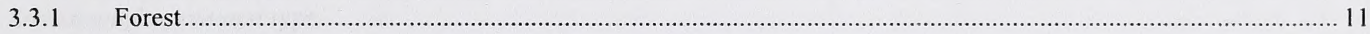

3.3.1.1 Pinus banksiana / Vaccinium spp. / Pleurozium schreberi Forest ........................................................... 11

3.3.1.2 Pinus banksiana / Alnus viridis - Vaccinium myrtilloides / Oryzopsis pungens Forest..................................... 15

3.3.1.3 Pinus banksiana / Arctostaphylos uva-ursi / Apocynum androsaemifolium Forest ........................................ 19

3.3.1.4 Pinus banksiana / Vaccinium vitis-idaea - Arctostaphylos uva-ursi Forest ................................................. 21

3.3.1.5 Pinus banksiana / Cladina mitis Forest....................................................................................................... 25

3.3.1.6 Picea glauca - Picea mariana / Rosa acicularis / Cornus canadensis Forest................................................... 28

3.3.1.7 Picea glauca - Picea mariana / Ledum groenlandicum /Equisetum arvense Forest ........................................ 32

3.3.1.8 Picea mariana - Larix laricina / Ledum groenlandicum / Tomentypnum nitens Forest................................... 34

3.3.1.9 Picea mariana - Larix laricina / Pleurozium schreberi Forest..................................................................... 38

3.3.1.10 Picea mariana - Larix laricina Wet Forest ........................................................................................... 41

3.3.1.11 Larix laricina / Betula pumila / Equisetum fluviatile Forest .............................................................................. 43

3.3.1.12 Populus tremuloides / Corylus cornuta / Aralia nudicaulis Forest ................................................................ 44

3.3.1.13 Populus tremuloides / Vaccinium myrtilloides / Arctostaphylos $u v a-u r s i$ Forest ........................................... 47

3.3.1.14 Populus tremuloides / Rosa acicularis / Aralia nudicaulis Forest ................................................................ 52

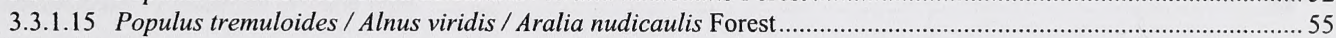

3.3.1.16 Betula papyrifera / Ledum groenlandicum / Equisetum sylvaticum Forest .................................................. 61

3.3.1.17 Betula papyrifera - Pinus banksiana / Alnus incana spp. tenuifolia / Aralia nudicaulis Forest ......................... 63

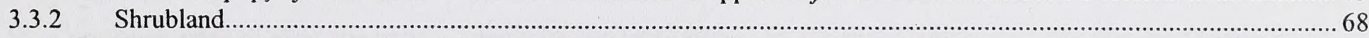

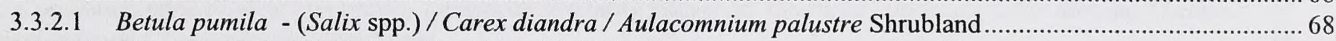

3.3.2.2 Salix planifolia / Calamagrostis canadensis Shrubland ….......................................................................... 71

3.3.2.3 Salix petiolaris / Carex diandra - Calamagrostis stricta Shrubland ................................................................ 75

3.3.2.4 Alnus viridis spp. crispa - Prunus pensylvanica / Aralia nudicaulis Shrubland .................................................. 77

3.3.2.5 Amelanchier alnifolia / Arctostaphylos uva-ursi / Oryzopsis pungens Dwarf-shrubland................................... 80

3.3.2.6 Arctostaphylos uva-ursi / Calamovilfa longifolia Dwarf-shrubland ................................................................... 83

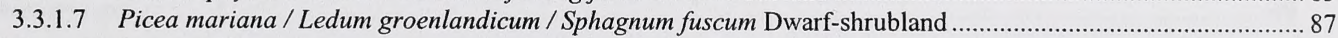

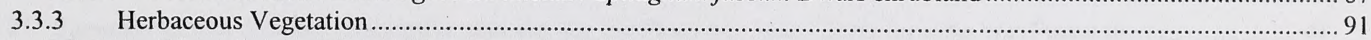

3.3.3.1 Carex diandra Wet Meadow Herbaceous Vegetation ................................................................................ 91

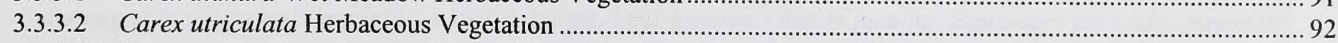

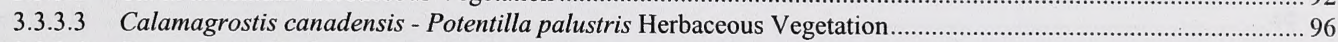

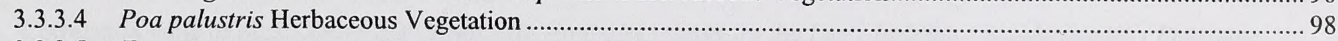

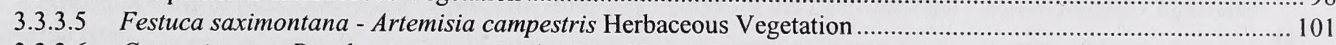

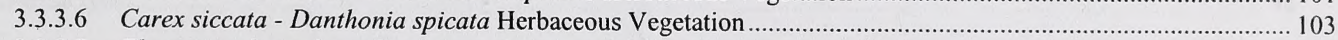

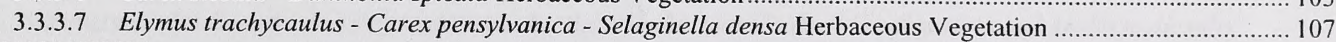

4.0 CONCLUSION 



\section{List of Tables}

Table 1. Precipitation and temperature data for the Holmes Crossing and North Buck Lake study areas (Source: Strong and Leggat 1992).

Table 2. Descriptions and codes used for the various vegetation strata.

Table 3. Summary of plot data and descriptive statistics for the Pinus banksiana / Vaccinium spp. / Pleurozium schreberi community type $(n=3)$.

Table 4. Correlation table of plant community types with similarity ratings for the Pinus banksiana / Vaccinium spp. / Pleurozium schreberi type.

Table 5. Summary of plot data and descriptive statistics for the Pinus banksiana / Alnus viridis - Vaccinium myrtilloides / Oryzopsis pungens community type $(\mathrm{n}=2)$.

Table 6. Correlation table of plant community types with similarity ratings for the Pinus banksiana / Alnus viridis - Vaccinium myrtilloides / Oryzopsis pungens type.

Table 7. Summary of plot data and descriptive statistics for the Pinus banksiana / Arctostaphylos uva-ursi / Apocynum androsaemifolium community type $(\mathrm{n}=2)$.

Table 8. Correlation table of plant community types with similarity ratings for the Pinus banksiana / Apocynum androsaemifolium - Arctostaphylos uva-ursi type

Table 9. Summary of plot data and descriptive statistics for the Pinus banksiana / Vaccinium vitis-idaea-Arctostaphylos uvaursi community type $(\mathrm{n}=1)$.

Table 10. Correlation table of plant community types with similarity ratings for the Pinus banksiana / Vaccinium vitis-idaea Arctostaphylos uva-ursi type.

Table 11. Summary of plot data and descriptive statistics for the Pinus banksiana / Cladina mitis community type ( $\mathrm{n}=3$ )..........26

Table 12. Correlation table of plant community types with similarity ratings for the Pinus banksiana / Cladina mitis community type.

Table 13. Summary of plot data and descriptive statistics for the Picea glauca - Picea mariana / Rosa acicularis / Cornus canadensis community type $(\mathrm{n}=1)$

Table 14. Correlation table of plant community types with similarity ratings for Picea glauca - Picea mariana / Rosa acicularis / Cornus canadensis type.

Table 15. Summary of plot data and descriptive statistics for the Picea glauca - Picea mariana / Ledum groenlandicum / Equisetum arvense community type $(\mathrm{n}=1)$

Table 16. Correlation table of plant community types with similarity ratings for the Picea mariana - Picea glauca / Ledum groenlandicum / Equisetum arvense type.

Table 17. Summary of plot data and descriptive statistics for the Picea mariana - Larix laricina / Ledum groenlandicum / Tomentypnum nitens community type $(\mathrm{n}=1)$.

Table 18. Correlation table of plant community types with similarity ratings for the Picea mariana - Larix laricina / Ledum groenlandicum / Tomentypnum nitens type.

Table 19. Summary of plot data and descriptive statistics for the Picea mariana - Larix laricina / Pleurozium schreberi community type $(n=2)$.

Table 20. Correlation table of plant community types with similarity ratings for the Picea mariana-Larix laricina / Pleurozium schreberi type.

Table 21. Summary of plot data and descriptive statistics for the Picea mariana - Larix laricina Wet Forest $(\mathrm{n}=1)$.

Table 22. Summary of plot data and descriptive statistics for the Larix laricina / Betula pumila / Equisetum fluviatile community type $(n=1)$.

Table 23. Correlation table of plant community types with similarity ratings for the Larix laricina / Betula pumila / Equisetum fluviatile type.

Table 24. Summary of plot data and descriptive statistics for the Populus tremuloides / Corylus cornuta / Aralia nudicaulis community type $(n=1)$.

Table 25. Correlation table of plant community types with similarity ratings for the Populus tremuloides / Corylus cornuta / Aralia nudicaulis type. 

Table 26. Summary of plot data and descriptive statistics for the Populus tremuloides / Vaccinium myrtilloides / Arctostaphylos uva-ursi community type $(\mathrm{n}=3)$.

Table 27. Correlation table of plant community types with similarity ratings for the Populus tremuloides / Vaccinium myrtilloides / Arctostaphylos uva-ursi type.

Table 28. Summary of plot data and descriptive statistics for the Populus tremuloides / Rosa acicularis / Aralia nudicaulis community type $(n=3)$.

Table 29. Correlation table of plant community types with similarity ratings for the Populus tremuloides / Rosa acicularis / Aralia nudicaulis type......

Table 30. Summary of plot data and descriptive statistics for the Populus tremuloides / Alnus viridis / Aralia nudicaulis community type $(n=5)$.

Table 31. Correlation table of plant community types with similarity ratings for the Populus tremuloides / Alnus viridis / Aralia nudicaulis type.

Table 32. Summary of plot data and descriptive statistics for the Betula papyrifera / Ledum groenlandicum / Equisetum sylvaticum community type $(\mathrm{n}=2)$..

Table 33. Correlation table of plant community types with similarity ratings for the Betula papyrifera / Ledum groenlandicum / Equisetum sylvaticum type.

Table 34. Summary of plot data and descriptive statistics for the Betula papyrifera-Pinus banksiana / Alnus incana spp tenuifolia / Aralia nudicaulis community type $(\mathrm{n}=1)$...

Table 35. Correlation table of plant community types with similarity ratings for the Betula papyrifera - Pinus banksiana / Alnus incana spp tenuifolia / Aralia nudicaulis type.

Table 36. Summary of plot data and descriptive statistics for the Betula pumila - (Salix spp.)/Carex diandra / Aulacomnium palustre Shrubland community type $(\mathrm{n}=1)$.

Table 37. Correlation table of plant community types with similarity ratings for the Betula pumila - (Salix spp.)/Carex diandra I Aulacomnium palustre Shrubland type.

Table 38. Summary of plot data and descriptive statistics for the Salix planifolia / Calamagrostis canadensis community type $(n=1)$.

Table 39. Correlation table of plant community types with similarity ratings for the Salix planifolia / Calamagrostis canadensis type.

Table 40. Summary of plot data and descriptive statistics for the Salix petiolaris / Carex diandra - Calamagrostis stricta community type $(n=3)$.

Table 41. Correlation table of plant community types with similarity ratings for the Salix petiolaris / Carex diandra Calamagrostis stricta type.

Table 42. Summary of plot data and descriptive statistics for the Alnus viridis spp. crispa - Prunus pensylvanica / Aralia nudicaulis community type $(\mathrm{n}=1)$.

Table 43. Correlation table of plant community types with similarity ratings for the Alnus viridis spp. crispa - Prunus pensylvanica / Aralia nudicaulis type.

Table 44. Summary of plot data and descriptive statistics for the Amelanchier alnifolia / Arctostaphylos uva-ursi / Oryzopsis pungens community type $(n=6)$.

Table 45. Correlation table of plant community types with similarity ratings for the Amelanchier alnifolia / Arctostaphylos uvaursi / Oryzopsis pungens type.

Table 46. Summary of plot data and descriptive statistics for the Arctostaphylos uva-ursi / Calamovilfa longifolia Dwarfshrubland $(\mathrm{n}=1)$.

Table 47. Correlation table of plant community types with similarity ratings for the Arctostaphylos uva-ursi / Calamovilfa longifolia type.

Table 48. Summary of plot data and descriptive statistics for the Picea mariana / Ledum groenlandicum / Sphagnum fuscum Dwarf-shrubland community type $(n=1)$.

Table 49. Correlation table of plant community types with similarity ratings for the Picea mariana / Ledum groenlandicum / Sphagnum fuscum type.

Table 50. Summary of plot data and descriptive statistics for the Carex diandra community type $(\mathrm{n}=1)$. 

Table 51. Correlation table of plant community types with similarity ratings for Carex diandra type......

Table 52. Summary of plot data and descriptive statistics for the Carex utriculata community type $(\mathrm{n}=1)$.

Table 53. Correlation table of plant community types with similarity ratings for the Carex utriculata type.

Table 54. Summary of plot data and descriptive statistics for the Calamagrostis canadensis - Potentilla palustris community type $(n=3)$.

Table 55. Correlation table of plant community types with similarity ratings for the Calamagrostis canadensis - Potentilla palustris type.

Table 56. Summary of plot data and descriptive statistics for the Poa palustris Semi-natural Seasonally Flooded Herbaceous Alliance type $(n=1)$.

Table 57. Correlation table of plant community types with similarity ratings for the Poa palustris Semi-natural Seasonally Flooded Herbaceous Alliance type.

Table 58. Summary of plot data and descriptive statistics for the Festuca saximontana-Artemisia campestris community type $(n=6)$.

Table 59. Correlation table of plant community types with similarity ratings for the Festuca saximontana-Artemisia campestris type.

Table 60. Summary of plot data and descriptive statistics for the Carex siccata-Danthonia spicata community type (n=4)..... 104

Table 61. Correlation table of plant community types with similarity ratings for the Carex siccata-Danthonia spicata type..... 105

Table 62. Summary of plot data and descriptive statistics for the Elymus trachycaulus - Carex pensylvanica - Selaginella densa Herbaceous Vegetation community type $(n=1)$.

Table 63. Correlation table of plant community types with similarity ratings for the Elymus trachycaulus - Carex pensylvanica Selaginella densa type.

Table 64. Summary of plant communities identified in the Holmes Crossing Ecological Reserve and North Buck Lake study area.

\section{List of Figures}

Figure 1. Dendogram displaying the plot groupings produced through agglomerative cluster analysis.

Figure 2. Diagram of plot ordination, with plant community groupings, based on Detrended Correspondence Analysis (DCA) of plot data. 


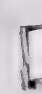

1

1

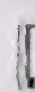

1

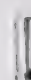




\section{List of Plates}

Plate 1. Ground disturbance caused by off-road vehicle use in the North Buck Lake study area. .......................................... 7

Plate 2. Pinus banksiana / Vaccinium spp. / Pleurozium schreberi Forest (P43)....................................................... 18

Plate 3. Pinus banksiana / Alnus viridis / Oryzopsis pungens Forest (P21) ................................................................ 18

Plate 4. Pinus banksiana / Arctostaphylos uva-ursi / Apocynum androsaemifolium Forest (P26). .......................................24

Plate 5. Pinus banksiana / Vaccinium vitis-idaea - Arctostaphylos uva-ursi Forest (P41) ...................................................24

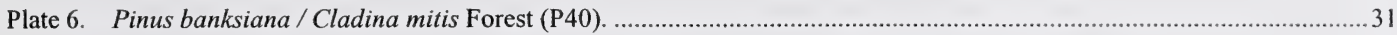

Plate 7. Picea glauca - Picea mariana / Rosa acicularis / Cornus canadensis Forest (P19).............................................31

Plate 8. Picea glauca - Picea mariana / Ledum groenlandicum / Equisetum arvense Forest (P37) .......................................37

Plate 9. Picea mariana - Larix laricina / Ledum groenlandicum / Tomentypnum nitens Forest (P30)....................................37

Plate 10. Picea mariana - Larix laricina / Pleurozium schreberi Forest (P7) ...................................................................42

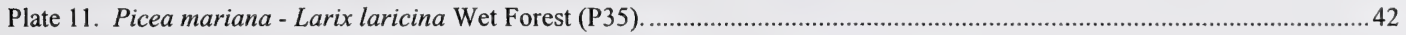

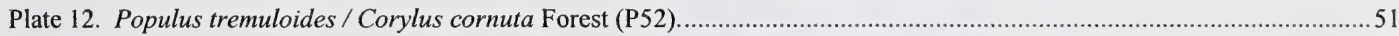

Plate 13. Populus tremuloides / Vaccinium myrtilloides / Arctostaphylos uva-ursi Forest (P64)..........................................51

Plate 14. Populus tremuloides / Rosa acicularis / Aralia nudicaulis Forest (P34) ............................................................60

Plate 15. Populus tremuloides / Alnus viridis / Aralia nudicaulis Forest (P50) ..............................................................60

Plate 16. Betula papyrifera / Ledum groenlandicum / Equisetum sylvaticum Forest (P46) ............................................67

Plate 17. Betula papyrifera-Pinus banksiana /Alnus incana spp tenuifolia /Aralia nudicaulis Forest (P5) ..............................67

Plate 18. Betula pumila - (Salix spp.) / Carex diandra / Aulacomnium palustre Shrubland (P32) ..........................................74

Plate 19. Salix planifolia - Calamagrostis canadensis Shrubland (P59) ......................................................................74

Plate 20. Salix petiolaris / Carex diandra - Calamagrostis stricta Shrubland (P31) .........................................................79

Plate 21. Alnus viridis spp. crispa - Prunus pensylvanica / Aralia nudicaulis Shrubland (P22) .............................................79

Plate 22. Arctostaphylos uva-ursi / Oryzopsis pungens Dwarf Shrubland (P2) ................................................................86

Plate 23. Arctostaphylos uva-ursi / Calamovilfa longifolia Dwarf Shrubland (P27).............................................................86

Plate 24. Picea mariana / Ledum groenlandicum / Sphagnum fuscum Dwarf-shrubland (P58)...........................................90

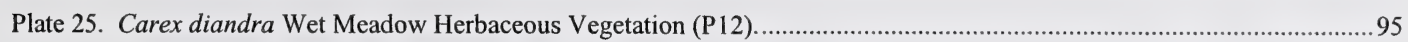

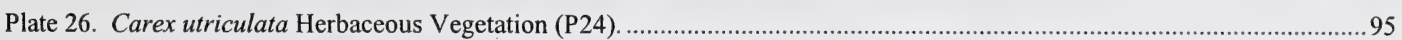

Plate 27. Calamagrostis canadensis - Potentilla palustris Herbaceous Vegetation (P48). .................................................. 100

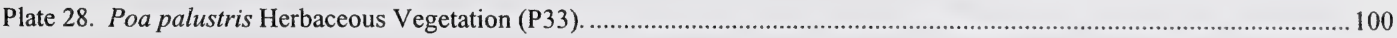

Plate 29. Festuca saximontana - Artemisia campestris Herbaceous Vegetation (P45)....................................................... 106

Plate 30. Carex siccata - Danthonia spicata Herbaceous Vegetation (P49) ....................................................................... 106

Plate 31. Elymus trachycaulus - Carex pensylvanica - Selaginella densa Herbaceous Vegetation (P11) ................................ 109

\section{List of Appendices}

Appendix I. Plant species list for the Boreal Sand Dunes study.

Appendix II. Results of Detrended Correspondence Analysis of plot data using PC-ORD (Version 4.25). 


\subsection{INTRODUCTION}

Alberta Natural Heritage Information Centre (ANHIC) is responsible for the inventory, assessment, and dissemination of information about elements of provincial biodiversity. Elements that are rare or have special conservation concern are included on tracking lists for monitoring and conservation purposes. Allen (2004) provides a preliminary list of Alberta plant community types that are considered "rare or special in some way". ANHIC requires that identification and assessment of plant communities in Alberta follow the standardised classification system developed by the International Classification of Ecological Communities (ICEC). Classification of Alberta plant communities will assist in the development of a Canadian National Vegetation Classification (CNVC). In the United States the ICEC has been adopted to develop a national classification system in that country (Grossman et al. 1998, NatureServe 2004, Jennings et al. 2003).

In Alberta, ANHIC has identified gaps in the knowledge base of provincial plant community types. Many rare or ecologically sensitive community types occur as small recurring patches associated with unique landforms and specific ecological site conditions. This has resulted in data gaps in plant communities associated with boreal sand dunes and sand plains. The Resource Data Branch of Alberta Sustainable Resource Development (ASRD) contracted Wildlands Ecological to complete an inventory of natural/semi-natural plant communities in the Holmes Crossing and North Buck Lake study areas. These study areas were selected for their representative sand dune and sand plain formations within the Boreal Dry Mixedwood and Boreal Central Mixedwood Natural Subregions.

\section{$1.1 \quad$ Objectives}

The following key project objectives were identified:

1) To develop a sampling protocol to collect floristics data on plant communities of the sand dunes and sand plains landscapes of Holmes Crossing Sandhills Ecological Reserve and North Buck Lake study areas;

2) To correlate plant community types identified for the study area with those described for similar areas in Alberta and adjacent jurisdictions, and to apply a similarity rating based on ratings developed by Corns (1983);

3) To develop a plant community classification for sand dune and sand plain natural/near-natural plant communities of the Boreal Dry Mixedwood and Central Mixedwood Natural Subregions;

4) To provide information regarding the spatial extent of proposed plant community types for further evaluation and assignment of a preliminary provincial rank; and

5) To produce a report summarising methodology, results, and identified plant community types. 
The Holmes Crossing Sandhills Ecological Reserve is located south of the Athabasca River approximately $4 \mathrm{~km}$ southwest of Fort Assiniboine. It was established as an ecological reserve in 1997 and it occupies about 1980 ha of Crown land. This Ecological Reserve covers all or portions of sections 7, 8, 916,17 , 18, 19, 20, 21, 28 and 29 of Twp. 61 Rge. 6 W4; and sections 12, 13 and 24 of Twp. 61 Rge. 7 W4. Sand dune features include a series of well preserved transverse dunes oriented in a northeast-southwest direction and composites of parabolic sand dunes (David 1977). This study area is located in the Mid Boreal Mixedwood Ecoregion (Strong and Leggat 1992) and the Central Mixedwood Natural Subregion (Alberta Environmental Protection 1994). Appendix I provide a list of common and scientific names of vascular and non-vascular plant species referred to in this report.

The Holmes Crossing transverse dune field is considered to be nationally significant (David 1977; Nelson et al. 1989). It occurred within the Lesser Slave Plain District characterised by undulating to rolling fluvial and eolian deposits that form part of the Eastern Alberta Plains physiographic region. This rolling eolian landscape has slope gradients of 0 to $15 \%$ while sand dunes have slopes of up to $45 \%$. The Holmes Crossing area is underlain by bentonitic sandstones and shales of the Upper Cretaceous Wapiti Formation Bedrock (Nelson et al. 1989). Surficial materials result from glacial deposits acted upon by water and wind erosion. These sand dunes were deposited by wind action as an ancient glacial lake receded. The sand was then quickly colonised by vegetation thus preserving their characteristic profiles. David (1977) suggested that the dunes were likely colonised soon after they were formed as a result of a rapid rise in water tables that provided favourable moisture conditions for plant growth. In a review by Nelson et al. (1989), soils in the Holmes Crossing study area consist of unconsolidated mineral matter with limited soil development. They indicated that Brunisols were common under forests stands and Regosols soils occurred on rapidly to poorly drained sites with recent erosion or flooding. Organic soils typically occur under very poorly drained sites, generally in interdune wetlands. Other depressions may have 40 to $60 \mathrm{~cm}$ of peat accumulation. Luvisol soils occur less frequently and were found on moderately to strongly rolling, moist eolian and alluvial sands and loamy sands.

The North Buck Lake study area is located approximately $15 \mathrm{~km}$ northeast of Boyle, Alberta. It consists of approximately 3600 ha of Crown Land that is very gently to gently rolling and hummocky. It includes all or portions of sections 19, 20, 29, 30,31, and 32 Twp. 65 Rge. 17 W4; sections 5 and 6 Twp. 66 Rge. 17 W4; 23, 24, 25, 26, 27, 35 and 36 Twp. 65 Rge. 18 W4; and sections 1, 2, 10, 11 and 12 Twp. 66 Rge. 18 W4. The study area includes a proposed provincial park and natural area located along the west and south sides of North Buck Lake. Eolian landforms in this study area were mainly non-linear and parabolic dunes with sections of sand plains. The proposed provincial park located north and east of Big Johnson (Chump Lake) is an area of remnant terraces with coarse textured glaciofluvial deposits (Hay and O'Leary 1988). The North Buck Lake study area occurs in the Low Boreal Mixedwood Ecoregion (Strong and Leggat 1992) and the Dry Mixedwood Natural Subregion (Alberta Environmental Protection 1994).

Surficial deposits in the Dry Mixedwood and Central Mixedwood Subregions are mainly ground and hummocky moraines or lacustrine materials (Alberta Environmental Protection 1994). The sand dunes and sand outwash plains found in the North Buck Lake study area are not common in the Dry Mixedwood Subregion. Throughout both Subregions soils in the sandy upland areas are typically Brunisols, while Organics and Gleysolic soils are dominant in lowland areas (Alberta Environmental Protection 1994). In sandy areas, jack pine is the dominant tree species while stands of aspen and balsam poplar occur on moister sites. Frequent fires maintain forests in jack pine and aspen with less frequently burned stands succeding to white spruce and balsam fir. Aspen forests have a high diversity of understorey species while sand dunes and plains mainly support jack pine stands, often with high percent cover of ground lichens. Black spruce and tamarack stands occur in lowland areas, and willow-sedge fens are common on wetter sites. Some peatlands occur in lowland areas. 
The climate of the Boreal Forest Natural Region is continental; characterised by short cool summers and long cold winters (Table 1) (Alberta Environmental Protection 1994). Contrasting micro-climatic differences between the south and north facing dune slopes in combination with ecological site conditions has a profound influence on plant community composition and structure (Nelson et al. 1989). This results in rapid changes in plant community types in accordance with the pronounced differences in site conditions between upland versus lowland sites, and north versus south facing slopes. The majority of precipitation falls between May and August, peaking in July. The Central Mixedwood Subregion climate is slightly wetter and cooler than the Dry Mixedwood Subregion (Alberta Environmental Protection 1994).

Table 1. Precipitation and temperature data for the Holmes Crossing and North Buck Lake study areas (Source: Strong and Leggat 1992).

\begin{tabular}{|l|l|c|c|c|c|c|c|c|}
\hline \multirow{2}{*}{$\begin{array}{l}\text { Study } \\
\text { Area }\end{array}$} & \multirow{2}{*}{ Ecoregion } & \multicolumn{3}{|c|}{ Summer Temperature $\left(\mathbf{C}^{\circ}\right)$} & \multicolumn{3}{c|}{ Winter Temperature $\left(\mathbf{C}^{\circ}\right)$} & Annual \\
\cline { 3 - 9 } & Mean & $\begin{array}{c}\text { Mean } \\
\text { Minimum }\end{array}$ & $\begin{array}{c}\text { Mean } \\
\text { Maximum }\end{array}$ & $\begin{array}{c}\text { Mean } \\
\text { Mean }\end{array}$ & $\begin{array}{c}\text { Mean } \\
\text { Maximimum } \\
\text { Maximum }\end{array}$ \\
\hline $\begin{array}{l}\text { North } \\
\text { Buck Lake }\end{array}$ & $\begin{array}{l}\text { Low Boreal } \\
\text { Mixedwood }\end{array}$ & 13.8 & 7.0 & 20.4 & -10.5 & -15.8 & -5.3 & 380 \\
\hline $\begin{array}{l}\text { Holmes } \\
\text { Crossing }\end{array}$ & $\begin{array}{l}\text { Mid Boreal } \\
\text { Mixedwood }\end{array}$ & 13.5 & 7.3 & 19.6 & -13.2 & -18.6 & -7.7 & 397 \\
\hline
\end{tabular}

Vegetation overviews of both study areas are provided by Alberta Environmental Protection (1994), Nelson et al. (1989), Strong and Leggat (1992), and Larsen (1990). Aspen and jack pine were the dominant tree species in the study area with aspen forests occurring on well-drained sandy veneers or blankets and jack pine stands on dry rapidly drained transverse or parabolic sand dunes. The understorey in aspen forests were species rich and typically include red-osier dogwood, green alder, prickly rose, willow, saskatoon, bluejoint, hairy wild rye, pea vine, and American vetch. Pine stands were commonly associated with alder, saskatoon, common blueberry, bog cranberry, bearberry, rice grass, lichens and feather mosses. White spruce stands commonly occur along the north facing slopes of drainage channels. White spruce also forms the understorey of aspen stands and in the absence of fire these stands may succeed to white spruce dominated communities. The lower understorey in white spruce stands consists of willow, prickly rose, red-osier dogwood, horsetails, and mosses. Black spruce is common in the area and forms pure stands in imperfectly to poorly drained wetland areas. It also forms mixed stands with white spruce on imperfectly to moderately well drained sites, with tamarack on poorly drained sites, and with aspen on more mesic sites. Black spruce is typically associated with tamarack, willow, dwarf birch, mosses, and sedges. Sedge fens occur on very poorly drained sites and these were eventually invaded by willow and dwarf birch.

Disturbance levels in the two study areas vary. In the Holmes Crossing Sandhills Ecological Reserve, there were few ground disturbances other than existing trails, seismic lines, and roads that were closed to motorised vehicles. By contrast, in the North Buck Lake study area, there has been significant past and present ground disturbance caused primarily by off-road recreational vehicles. In the latter study area there were many trails, roads, and seismic lines. 


\subsection{Data Collection}

Field sampling focused on natural/semi-natural plant associations. Five (5) plots were completed in major plant association types that were poorly correlated to those identified on previous studies. Three (3) plots were placed in poorly correlated minor plant associations that occurred infrequently over the landscape. A potential plant community list was developed by reviewing types previously identified by Nelson et al. (1989), Coenen (2003), Meijer (2002a, 200b, 2002c), Allen (2004) and others. While taking into consideration differences in scale, this list was used as a tentative guide for directing field investigations.

Standard Site Description Forms (RDB 2002-1), Vegetation Description Forms (RDB 2002-3) and Vegetation Inventory Forms (MF5 Rev. 5/99) were used to record detailed plot data, site location, and GPS co-ordinates. Percent cover of vascular and non-vascular plants was estimated occularily within plots. All dominant and co-dominant differential species and other diagnostic species were recorded for each stratum. Photographs of all representative plant associations were taken.

Sampling protocols adhered to the Ecological Land Survey Site (Alberta Sustainable Resource Development 2003). Plot sizes for sites with tree strata were $11.3 \mathrm{~m}$ radius $\left(400 \mathrm{~m}^{2}\right)$, and for shrub and herbaceous strata a $5.6 \mathrm{~m}$ radius plot $\left(100 \mathrm{~m}^{2}\right)$ was used. The percent ground cover of all plant species was recorded. Plot dimensions were adjusted to stay within the plant community type where patch sizes were small. Daubenmire transects were used to sample plant communities dominated by graminoids and/or herbaceous cover. In these types a Daubenmire sampling frame $(0.20 \mathrm{~m} \mathrm{x} 0.50 \mathrm{~m})$ was placed at $1 \mathrm{~m}$ intervals along a $10 \mathrm{~m}$ transect (i.e. 10 sub-plots totalling $1.0 \mathrm{~m}^{2}$ ). Transects were centred within the 100 $\mathrm{m}^{2}$ plots depending on the size and distribution of the plant community being sampled. Plant communities occurring in small patches were sampled by reducing the length of the Daubenmire transect to stay within the boundaries of the type. The smallest community to be sampled was $1 \mathrm{~m}^{2}$ and in this case subplots would be adjacent to each other and covered the entire patch.

\subsection{Data Analysis}

Three different analyses were used to determine plant community types and species groupings. The first was a subjective grouping based on the initial literature review, field observations and a preliminary review of the data sheets. Field data was then entered into a spreadsheet and imported into PC-ORD Version 4.25 (McCune and Mefferd 1999) for analysis. The second analysis then involved an agglomerative cluster analysis using Ward's linkage method and relative Euclidean distance to measure dissimilarity between plots. The results of this analysis were then graphed as a dendrogram. The third method involved Detrended Correspondence Analysis (DECORANA ) which compares similarity and dissimilarity between plot data. The results of the last analysis were plotted graphically on two sets of axis to indicate potential plant communities based on species distribution and groupings. Once community types had been determined summary statistics were calculated for each including mean percent cover, Standard Error of the mean (SE), constancy (\% of plots with species), and prominence (

\footnotetext{
$\sqrt{\text { mean cover } x \text { constancy }}$ ).
} 


\subsection{Reporting}

The framework for plant community descriptions is adapted from protocols established by the International Classification of Ecological Communities (Grossman et al. 1998, Jennings et al. 2003). Stratum definitions (Table 2) are based on Alberta Sustainable Resource Development (2003). Plant community or plant association classifications refer to existing vegetation including all stages of succession (BraunBlanquet 1965). Nomenclature for vascular plants follows Moss (1983) with updates according to Flora of North America (1993 - 2004) and ANHIC (2002). Non-vascular plant nomenclature follows Anderson et al. (1990) for brown mosses, Anderson (1990) for Sphagnum spp., Stotler and Crandall-Stotler (1977) for liverworts, and Esslinger and Egan (1995) for lichens. Common names generally follow Alberta Environmental Protection (1993).

Table 2. Descriptions and codes used for the various vegetation strata.

\begin{tabular}{|c|c|}
\hline Code & Strata \\
\hline T1 & Tree (Main Canopy) \\
\hline T2 & Tree (Understorey) \\
\hline S1 & Tall Shrub $(2-5 \mathrm{~m})$ \\
\hline S2 & Medium Shrub $(0.5-2 \mathrm{~m})$ \\
\hline S3 & Low Shrub $(<0.5 \mathrm{~m})$ \\
\hline
\end{tabular}

\begin{tabular}{|c|c|}
\hline Code & Strata \\
\hline H & Herbs (Forbs) \\
\hline G & Graminoids \\
\hline M & Moss \\
\hline L & Lichen \\
\hline E & Epiphytes \\
\hline
\end{tabular}

\subsubsection{Vegetation Classification System}

Classification of terrestrial vegetated communities adhered to the standards presented by Grossman et al. (1998) and Jennings et al. (2003). This hierarchical system lists terrestrial ecological communities first by physiognomic characteristics, and then by floristics. The physiognomic groupings include Class (1), Subclass (2), Group (3), Subgroup (4), and Formation (5).

1) Class Level: At this level the vegetation structure of the dominant uppermost strata determines the Class as one of the following:

1. Forest/Woodland - Trees with crowns overlapping (25-100\% cover)

2. Shrubland - Shrubs generally $>0.5 \mathrm{~m}$ tall forming $>25 \%$ cover

3. Dwarf-shrubland - Shrubs $<0.5 \mathrm{~m}$ tall forming $>25 \%$ cover

4. Herbaceous - Graminoids, ferns and forbs dominate

5. Nonvascular - bryophytes, lichens and algae dominate

6. Sparse - Abiotic substrate dominates

2) Subclass Level: This level is based on the growth-form characteristics of the dominant life form. Generally, this is determined by leaf structure and phenology (e.g. evergreen, deciduous, mixed evergreen/deciduous), persistence (i.e. perennial, annual), and substrate characteristics (e.g. rocks, sand, exposed lakeshore).

3) Group Level: At this classification level community types were determined by leaf characteristics (broad leaf, needle, scale, etc.). Herbaceous and nonvascular classes were separated based on the presence of woody plant strata. Sparse vegetation communities were separated on the basis of topographic position (e.g. shorelines, cliffs). 
4) Subgroup Level: At this level a further division of each group is based on their Natural/Seminatural or Cultural origins.

5) Formation Level: The Formation Level is determined by evaluating vegetation physiognomy or structure based on broad environmental factors such as: landscape position and hydrological regime (e.g. Temperate or Subpolar Temperate or Subpolar Deciduous shrubland). An adaptation of the Cowardin System (Grossman et. al 1998) was used to describe hydrological regimes of wetland plant communities.

Floristic Level: There were two final levels in the classification hierarchy both based on floristics. These include the Alliance and the Association both defined by dominant species in the plant community. Jennings et al. (2003) document detailed guidelines for describing these levels providing a further refinement of the guidelines initially established by Grossman et al. (1998).

1) Alliance Level: The alliance is a physiognomically uniform group of plant associations characteristically with one or more diagnostic plant species, generally, occurring in the uppermost stratum

2) Association Level: This is the lowest level of the hierarchy and is defined as a plant community type with definite floristic composition, uniform habitat conditions, and uniform physiognomy. Diagnostic species with generally a minimum of $60 \%$ constancy were used to describe the type. Species occurring in the uppermost strata were listed first (separated by a hyphen (-) if in the same strata, and a slash (/) if in separate strata) and then diagnostic species in each successive lower level of strata. Species names were listed in decreasing order of dominance or constancy for each stratum.

\subsubsection{Floristic Unit Classification Confidence Level}

Plant associations described in this report were rated according to our confidence level in the field data and description as per Grossman et al. (1998) and Jennings et al. (2003). For previously described types the rating indicates how well stands match the existing published description for the type. For new types it is based on how common the community type appeared to be in the study area and Alberta, how consistent the floristic composition was between stands, and/or how the stand relates to descriptions of similar types. Based on Jennings et al. (2003), Confidence Level 1 (Strong) indicates a high degree of quantitative analysis from detailed plots and that the type is within the known range of distribution for the published type. Level 2 (Moderate) includes types that were poorly correlated to published types, lack quantitative data, and/or distribution of the type is uncertain. Level 3 (Weak) types were based on limited, unpublished, or weak plot data, or qualitative descriptions only. This type may have potential to be listed as distinct plant association type based on observations by qualified researchers. Such types may be recurring over the landscape, have very distinct vegetative physiognomy, and/or dominance and constancy of plant species.

\subsubsection{Plant Community Similarity Rating}

A literature review was completed to identify similar types within Alberta and North America. This included a thorough search of plant associations and alliances listed by NatureServe (2004) and Allen (2004). The classification scheme and unique identifier code reported for previously identified plant community types was included in each community summary. Brief overviews for each plant community included how common the type was in the study area, typical ecological site conditions, and plant species composition. A literature review was completed for each type and a correlation table compared the similarity of the reviewed type with the current classification. Each plant association was also assigned a 
similarity rating according to Corns (1983) and Strong (2002). The similarity ratings were based on the following criteria:

Rating
1
2
3

\section{Description}

Identical to very similar ecological niche and plant species composition.

Similar but occupies a slightly different ecological niche or has as slightly different plant species composition.

Several similarities but there were important differences in the ecological niche or in the plant species composition.

\subsection{RESULTS AND DISCUSSION}

\subsection{Field Program}

A total of 32 plots were completed in each study area between the $12^{\text {th }}$ and $23^{\text {rd }}$ of July 2004 . These 64 plots were distributed spatially throughout each study area capturing a wide range of plant community types. Plots P1 to P32 were completed in the Holmes Crossing Sandhills Ecological Reserve and Plots P33 to P64 were completed in the North Buck Lake study area. A variety of site positions and ecological niches were sampled including dry sand dunes, sand plains, riparian areas, sedge fens, peatland bogs, mesic forests, lake shore margins, and other sites. The vegetation in the Holmes Crossing Sandhills Ecological Reserve was found to be largely undisturbed and in a mostly natural state. However, in the North Buck Lake study area there were substantial areas of disturbance caused by recreational off-road vehicle use (Plate 1). Ground disturbances were mainly observed in grasslands, herb fields, forest openings, open forests, shoreline margins, and other open areas permitting easy access. Plant communities in both study areas were mainly composed of indigenous species with generally only minor occurrence of introduced or invasive species.

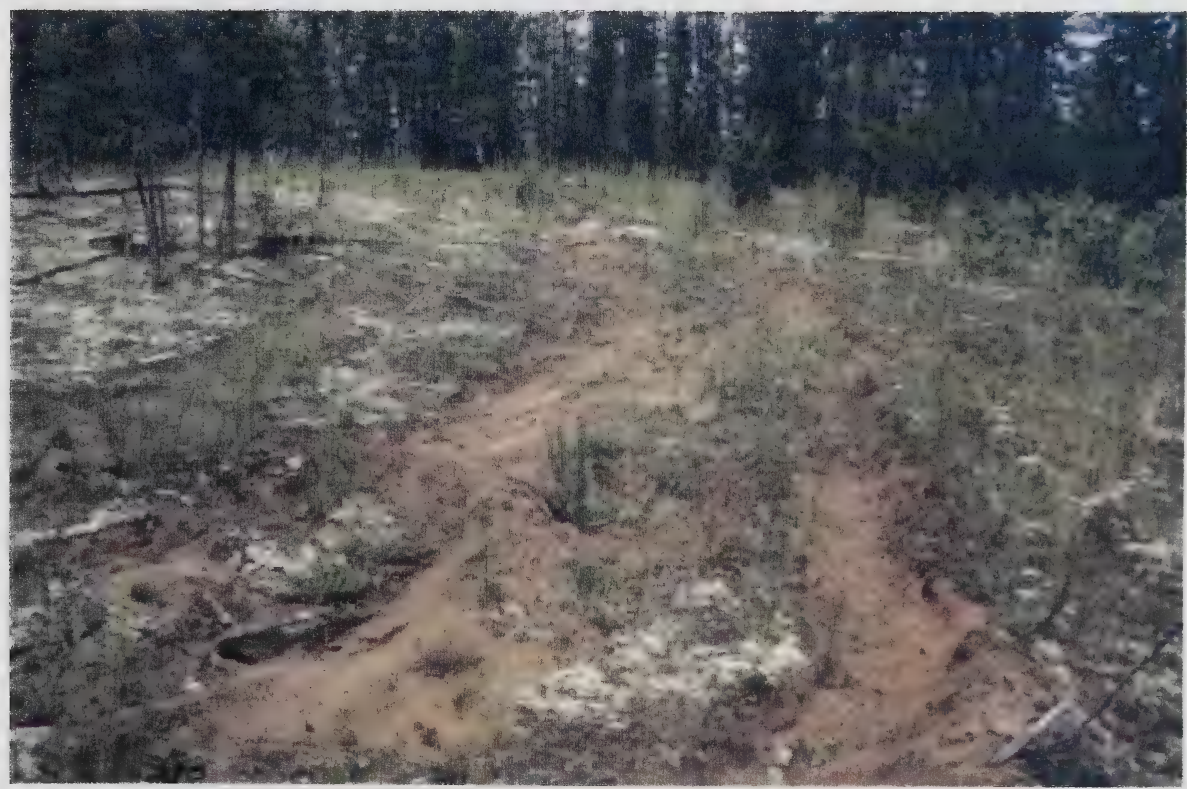

Plate 1. Ground disturbance caused by off-road vehicle use in the North Buck Lake study area. 
Soil textures throughout the majority of both study areas consisted of fine sands under jack pine forests, dry shrublands, herbaceous openings and other submesic to xeric communities. Commonly the duff and organic layer in these stands was less than 1 to $2 \mathrm{~cm}$ thick. In more mesic closed canopy jack pine stands the organic component was usually 3 to $5 \mathrm{~cm}$ thick over fine sands. Aspen stands typically had a 3 to $5 \mathrm{~cm}$ duff layers with a 3 to $7 \mathrm{~cm}$ depth of loamy fine sand layer over fine sand. Lowland black spruce stands often had a 5 to $12 \mathrm{~cm}$ duff layer over fine sand. In wetland areas the organic layer was usually greater than $25 \mathrm{~cm}$.

Sand dunes and sand plains in both study areas were generally well stabilised by established graminoid, herbaceous, or forest cover vegetation. Likely due to the slightly higher moisture levels, uplands in the Holmes Crossing Sandhills Ecological Reserve supported mainly closed canopy forests and lowlands were densely vegetated with either black spruce bogs or sedge-shrub fens. In the Holmes Crossing area there were only a few small areas with significant patches of exposed soil that were mostly associated with disturbances along trails. No significant blowouts or other active sand areas were observed. The North Buck Lake study area also supported a range of mature well-established vegetation communities. However, in contrast to the Holmes Crossing Sandhills Ecological Reserve there were more small patches of open sand and exposed soil associated with sparse grassland cover, dry-land herbaceous vegetation, or with dry forest openings. As noted above many of these areas also had some level of ground disturbance caused by off-road vehicle use. In the absence of these disturbances it is expected that herbaceous and graminoid cover levels would be higher and exposed soil values would be lower. Plots completed on the current study avoided areas with obvious disturbance.

\subsection{Data Analysis}

Analysis of plot data resulted in the identification of 31 potential plant associations including 17 forest, 7 shrubland and 7 herbaceous vegetation plant communities. There were 5 jack pine types, 1 white spruce, 4 black spruce, 1 tamarack, 4 aspen and 2 white birch types identified. Shrubland types included 1 bog birch, 2 willow wetlands, 1 green alder, and 2 bearberry types. Herbaceous Vegetation types included 2 wet sedge fens, 1 bluejoint wet meadow, 1 fowl grass shoreline, 1 Rocky Mountain fescue - plains wormwood xeric opening, 1 hay sedge-poverty oat grass, and 1 slender wheat grass community.

The final plant community types were determined by comparing the list of types generated by the fieldwork against an evaluation of the cluster analysis groupings that is displayed in the dendogram presented in Figure 1. Output results of the DCA analysis (PC-ORD Version 4.25) are presented in Appendix II and plotted in Figure 2. All data analysis was completed using plant species cover separated out by strata and the final analysis of community types took this factor into account. For example in Figure 2, Plot 18 appeared to be a unique type but upon closer examination there was substantial cover of mature aspen in the T2 stratum and therefore it was grouped with Plots 3, 17, 23, and 50. Assessment of these combined plots resulted in the concept for the Populus tremuloides / Alnus viridis / Aralia nudicaulis Forest community type. 
Figure 1. Dendogram displaying the plot groupings produced through agglomerative cluster analysis.

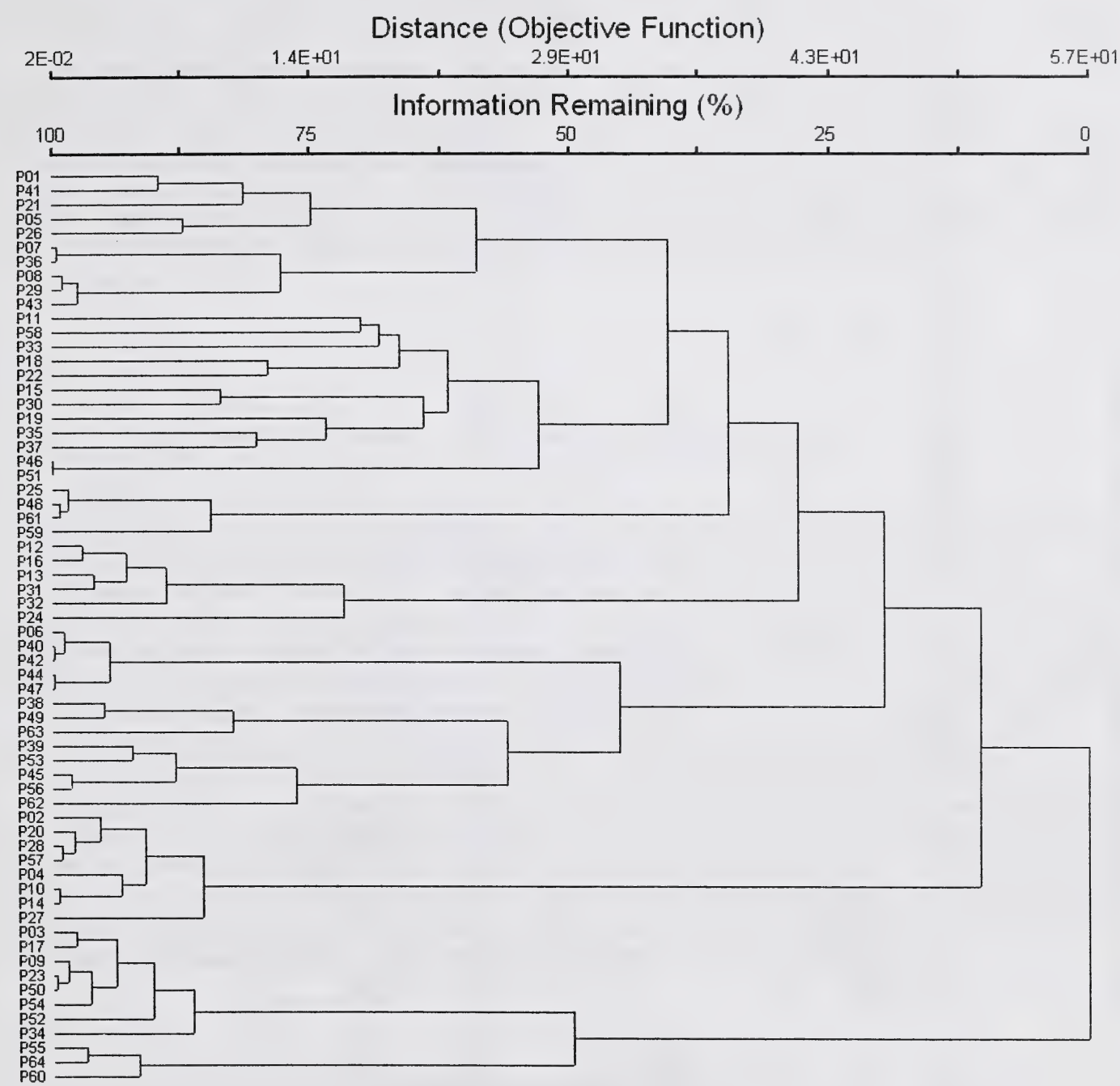




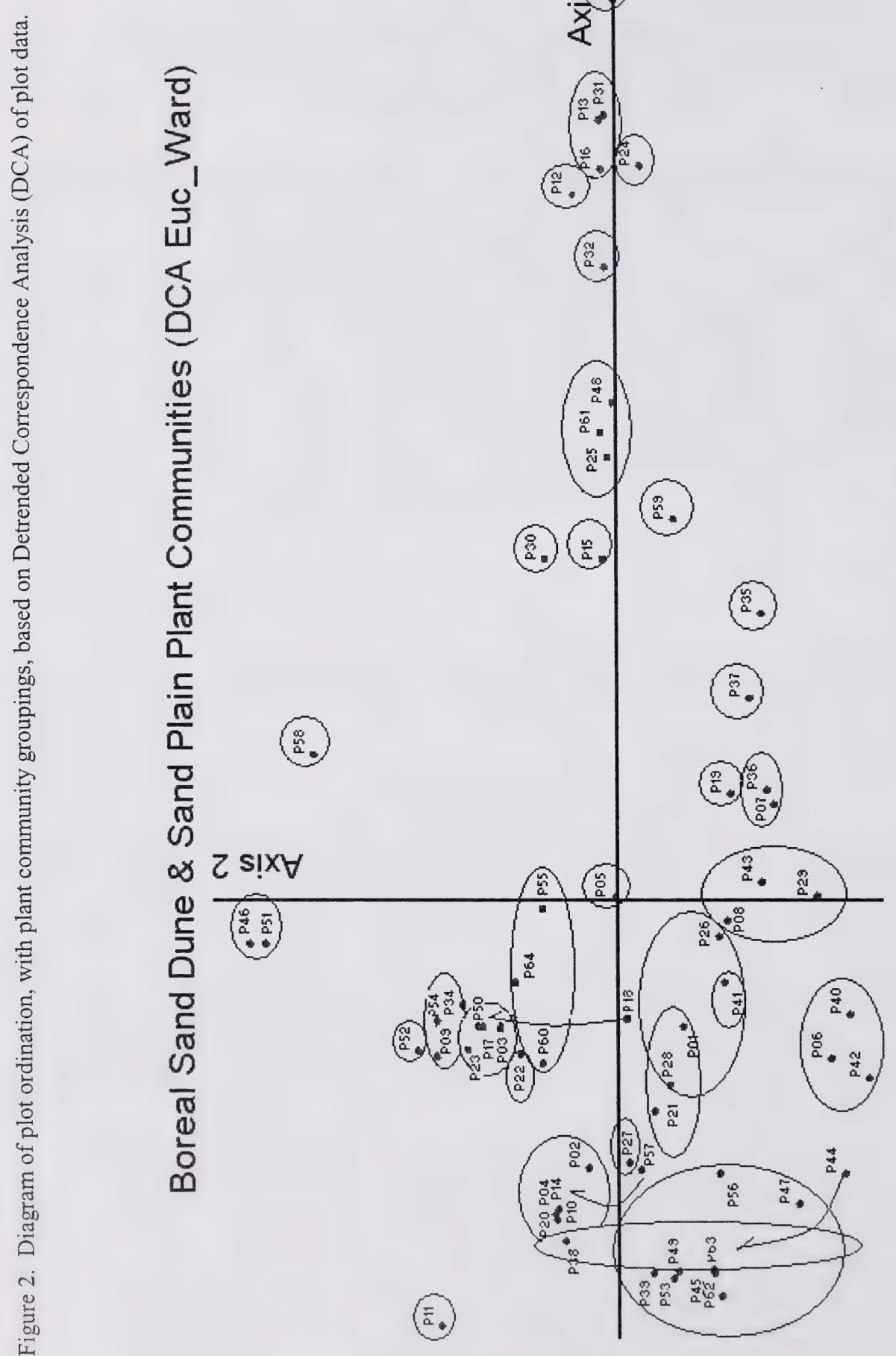




\subsection{Classifications}

In this section each plant community type (CT) is named and characterised in terms of typical site conditions and plant species composition. The proposed or existing ICEC classification scheme with unique identifier code and a classification confidence level are also presented. Following this is a list of dominant, co-dominant and diagnostic ( $>60 \%$ constancy) species for each type. Generally, plants species were recorded in diminishing order of dominance or importance starting with the upper stratum and moving progressively towards lower strata (i.e. T1 layer to $\mathrm{M}$ layer). For each type a plot summary table with descriptive statistics is provided. Literature reviews describe similar community types found in Alberta and other jurisdictions in North America. Finally a correlation table is included with similarity ratings for each reviewed type compared to the classification being discussed. Colour plates showing representative plant communities for the each type are included immediately after their summaries. Plot numbers for each photo are indicated at the end of the plate captions.

\subsubsection{Forest}

\subsubsection{Pinus banksiana /Vaccinium spp. / Pleurozium schreberi Forest}

Jack Pine / Blueberry species / Schreber's moss Forest

This community was common in both the Holmes Crossing Sandhills Ecological Reserve and the North Buck Lake study area where it occurred on cool north to northeast aspects. Slope gradients were normally gentle ranging between $5 \%$ and $22 \%$. Site positions were commonly toe and lower slopes, however this community type may extend to upper slopes. Soils were typically well-drained with mesic to sub-mesic moisture levels and a mesotrophic nutrient regime. These stands had closed canopies of Pinus banksiana that may include a minor amount of Populus tremuloides as scattered trees. The shrub layer consisted of Ledum groenlandicum, Vaccinium myrtilloides, and Alnus viridis. Other common plants included Vaccinium vitis-idaea, Cornus canadensis, Aralia nudicaulis, Maianthemum canadense, and Linnaea borealis. Pleurozium schreberi formed a dense carpet of moss with lesser amounts of Hylocomium splendens. Usnea spp. was a common epiphyte in these stands and it may have significant percent cover. A summary of the vascular and non-vascular plant species occurring in this type is provided in Table 3. There was considerable variation in the dominance of plant species (e.g. Vaccinium spp.) within the plots completed and additional sampling may result in splitting these into two or more community types. For example, Plot \# 8 fit well in terms of floristics but in contrast it also had significant cover of Populus iremuloides (10\%) and Aralia nudicaulis (15\%).

Class: Forest

Subclass: Evergreen forest

Group: Temperate or subpolar needle-leaved evergreen forest

Subgroup: Natural/Semi-natural

Formation: Rounded-crowned temperate or subpolar needle-leaved evergreen forest

Alliance: Pinus banksiana Forest

Association: Pinus banksiana / Vaccinium spp. / Pleurozium schreberi Forest

Unique Identifier: $\mathrm{n} / \mathrm{a}$

Classification Confidence Level: 2 (Moderate) Only three (3) plots were completed for this type and there was considerable variation in floristics among plots and in the literature describing similar types. This type is widespread throughout the boreal region.

Dominant Species: Pinus banksiana, Pleurozium schreberi, Hylocomium splendens, Usnea spp. Co-Dominant Species: Populus tremuloides, Pinus banksiana, Alnus viridis, Vaccinium myrtilloides, Vaccinium vitis-idaea, Ledum groenlandicum, Cornus canadensis, Aralia nudicaulis, Maianthemum canadense 
Table 3. Summary of plot data and descriptive statistics for the Pinus banksiana / Vaccinium spp. / Pleurozium schreberi community type $(\mathrm{n}=3)$.

\begin{tabular}{|c|c|c|c|c|c|c|c|c|c|}
\hline \multirow[b]{2}{*}{ Strata } & \multirow[b]{2}{*}{ Code } & \multirow[b]{2}{*}{ Species } & \multicolumn{3}{|c|}{ Plots } & \multirow[b]{2}{*}{ Mean } & \multirow[b]{2}{*}{$\mathrm{SE}$} & \multirow[b]{2}{*}{ Constancy } & \multirow[b]{2}{*}{ Prominence } \\
\hline & & & P08 & P29 & $\mathbf{P 4 3}$ & & & & \\
\hline M & PLEUSCH & Pleurozium schreberi & 60.0 & 90.0 & 86.0 & 78.7 & 9.4 & 100.0 & 88.7 \\
\hline $\mathrm{T} 1$ & PINUBAN & Pinus banksiana & 30.0 & 50.0 & 10.0 & 30.0 & 11.5 & 100.0 & 54.8 \\
\hline $\mathrm{E}$ & USNEA\$\$\$ $\$$ & Usnea spp. & 25.0 & 5.0 & 5.0 & 11.7 & 6.7 & 100.0 & 34.2 \\
\hline M & HYLOSPL & Hylocomium splendens & 6.0 & 5.0 & 0.1 & 3.7 & 1.8 & 100.0 & 19.2 \\
\hline S3 & LEDUGRO & Ledum groenlandicum & 0.1 & 1.0 & 9.0 & 3.4 & 2.8 & 100.0 & 18.3 \\
\hline S3 & VACCMYR & Vaccinium myrtilloides & 1.0 & 0.1 & 8.0 & 3.0 & 2.5 & 100.0 & 17.4 \\
\hline S3 & VACCVIT & Vaccinium vitis-idaea & 0.1 & 0.0 & 10.0 & 3.4 & 3.3 & 66.7 & 15.0 \\
\hline $\mathrm{T} 2$ & PINUBAN & Pinus banksiana & 0.0 & 0.0 & 20.0 & 6.7 & 6.7 & 33.3 & 14.9 \\
\hline S1 & ALNUVIR & Alnus viridis & 6.0 & 3.0 & 0.0 & 3.0 & 1.7 & 66.7 & 14.1 \\
\hline $\mathrm{H}$ & ARALNUD & Aralia nudicaulis & 15.0 & 0.0 & 0.0 & 5.0 & 5.0 & 33.3 & 12.9 \\
\hline $\mathrm{T} 1$ & POPUTRE & Populus tremuloides & 10.0 & 0.0 & 0.0 & 3.3 & 3.3 & 33.3 & 10.5 \\
\hline $\mathrm{H}$ & MAIACAN & Maianthemum canadense & 1.0 & 0.1 & 2.0 & 1.0 & 0.5 & 100.0 & 10.2 \\
\hline S3 & CORNCAN & Cornus canadensis & 4.0 & 0.1 & 0.0 & 1.4 & 1.3 & 66.7 & 9.5 \\
\hline T2 & BETUPAP & Betula papyrifera & 0.0 & 2.0 & 2.0 & 1.3 & 0.7 & 66.7 & 9.4 \\
\hline S3 & LINNBOR & Linnaea borealis & 1.0 & 0.1 & 1.0 & 0.7 & 0.3 & 100.0 & 8.4 \\
\hline M & DICRPOL & Dicranum polysetum & 0.0 & 3.0 & 0.1 & 1.0 & 1.0 & 66.7 & 8.3 \\
\hline M & PTILCRI & Ptilium crista-castrensis & 3.0 & 0.0 & 0.1 & 1.0 & 1.0 & 66.7 & 8.3 \\
\hline S1 & PINUBAN & Pinus banksiana & 0.0 & 0.0 & 5.0 & 1.7 & 1.7 & 33.3 & 7.5 \\
\hline $\mathrm{E}$ & EPIPHYT & Epiphyte spp. & 0.0 & 5.0 & 0.0 & 1.7 & 1.7 & 33.3 & 7.5 \\
\hline S2 & PICEGLA & Picea glauca & 1.0 & 0.0 & 1.0 & 0.7 & 0.3 & 66.7 & 6.7 \\
\hline S3 & PRUNVIR & Prunus virginiana & 3.0 & 0.0 & 0.0 & 1.0 & 1.0 & 33.3 & 5.8 \\
\hline S3 & ROSAACI & Rosa acicularis & 3.0 & 0.0 & 0.0 & 1.0 & 1.0 & 33.3 & 5.8 \\
\hline S3 & PINUBAN & Pinus banksiana & 0.0 & 0.0 & 1.0 & 0.3 & 0.3 & 33.3 & 3.3 \\
\hline $\mathrm{T} 2$ & PICEMAR & Picea mariana & 0.0 & 1.0 & 0.0 & 0.3 & 0.3 & 33.3 & 3.3 \\
\hline S3 & ARCTUVA & Arctostaphylos uva-ursi & 0.0 & 0.0 & 1.0 & 0.3 & 0.3 & 33.3 & 3.3 \\
\hline $\mathrm{L}$ & CLADMIT & Cladina mitis & 0.0 & 0.0 & 1.0 & 0.3 & 0.3 & 33.3 & 3.3 \\
\hline S1 & BETUPAP & Betula papyrifera & 1.0 & 0.0 & 0.0 & 0.3 & 0.3 & 33.3 & 3.3 \\
\hline S1 & PICEMAR & Picea mariana & 0.0 & 1.0 & 0.0 & 0.3 & 0.3 & 33.3 & 3.3 \\
\hline $\mathrm{H}$ & CAMPROT & Campanula rotundifolia & 0.1 & 0.1 & 0.1 & 0.1 & 0.0 & 100.0 & 3.2 \\
\hline G & ORYZPUN & Oryzopsis pungens & 0.1 & 0.0 & 0.1 & 0.1 & 0.0 & 66.7 & 2.1 \\
\hline H & EPILANG & Epilobium angustifolium & 0.1 & 0.1 & 0.0 & 0.1 & 0.0 & 66.7 & 2.1 \\
\hline $\mathrm{L}$ & CLADONI & Cladonia spp. & 0.1 & 0.1 & 0.0 & 0.1 & 0.0 & 66.7 & 2.1 \\
\hline G & ELYMINN & Leymus innovatus & 0.1 & 0.1 & 0.0 & 0.1 & 0.0 & 66.7 & 2.1 \\
\hline S3 & RUBUIDA & Rubus idaeus & 0.1 & 0.1 & 0.0 & 0.1 & 0.0 & 66.7 & 2.1 \\
\hline S3 & PICEGLA & Picea glauca & 0.0 & 0.0 & 0.1 & 0.0 & 0.0 & 33.3 & 1.1 \\
\hline S3 & BETUPAP & Betula papyrifera & 0.1 & 0.0 & 0.0 & 0.0 & 0.0 & 33.3 & 1.1 \\
\hline S3 & PRUNPEN & Prunus pensylvanica & 0.0 & 0.0 & 0.1 & 0.0 & 0.0 & 33.3 & 1.1 \\
\hline $\mathrm{T} 2$ & POPUTRE & Populus tremuloides & 0.1 & 0.0 & 0.0 & 0.0 & 0.0 & 33.3 & 1.1 \\
\hline S2 & SALIBEB & Salix bebbiana & 0.0 & 0.1 & 0.0 & 0.0 & 0.0 & 33.3 & 1.1 \\
\hline $\mathrm{H}$ & GALIBOR & Galium boreale & 0.1 & 0.0 & 0.0 & 0.0 & 0.0 & 33.3 & 1.1 \\
\hline S2 & PRUNPEN & Prunus pensylvanica & 0.1 & 0.0 & 0.0 & 0.0 & 0.0 & 33.3 & 1.1 \\
\hline $\mathrm{H}$ & MELALIN & Medicago lupulina & 0.0 & 0.0 & 0.1 & 0.0 & 0.0 & 33.3 & 1.1 \\
\hline $\mathrm{H}$ & DRYOCAR & Dryopteris carthusiana & 0.1 & 0.0 & 0.0 & 0.0 & 0.0 & 33.3 & 1.1 \\
\hline M & POLYPIL & Polytrichum piliferum & 0.1 & 0.0 & 0.0 & 0.0 & 0.0 & 33.3 & 1.1 \\
\hline S2 & POPUTRE & Populus tremuloides & 0.1 & 0.0 & 0.0 & 0.0 & 0.0 & 33.3 & 1.1 \\
\hline $\mathrm{H}$ & VIOLREN & Viola renifolia & 0.1 & 0.0 & 0.0 & 0.0 & 0.0 & 33.3 & 1.1 \\
\hline
\end{tabular}


Diagnostic Species: Pinus banksiana, Vaccinium myrtilloides, Vaccinium vitis-idaea, Ledum groenlandicum, Linnaea borealis, Maianthemum canadense, Pleurozium schreberi, Hylocomium splendens, Usnea spp.

\section{Literature Review:}

Nelson et al. (1989) identified a Pinus banksiana / Alnus crispa / Linnaea borealis - Vaccinium vitis-idaea community that occurred in the Holmes Crossing Sandhills Ecological Reserve. This type also occupied similar sites and was composed of largely the same plant species. The main differences were its higher cover of Alnus viridis ( $>20 \%$ mean cover), Linnaea borealis (27\%), Prunus pensylvanicus ( $7 \%$ ), Vaccinium vitis-idaea (18\%), Hylocomium splendens (10\%), lack of Ledum groenlandicum, and substantially less cover of Pleurozium schreberi.

Meijer (2002c) identified a Pinus banksiana / Vaccinium myrtilloides / Pleurozium schreberi type from the Marguerite Crag and Tail Wildland Provincial Park in northeastern Alberta. This type had $60 \%$ cover of Vaccinium myrtilloides, 3\% cover of $V$. vitis-idaea, and Pleurozium schreberi cover was lower at $40 \%$. Another similar type that was recorded from this Park was the Pinus banksiana / Pleurozium schreberi community type (Meijer 2002c). This community was also quite similar in species composition but only had trace amounts of Vaccinium myrtilloides and $V$. vitis-idaea. Raup and Argus (1982) provide a general description of a Pinus banksiana (Picea mariana) / Ledum groenlandicum type that occupied lowland pine stands in the Lake Athabasca area. Associated plant species included Kalmia polifolia, Andromeda polifolia, Chamaedaphne calyculata, and Vaccinium uliginosum. Herbs included Calamagrostis canadensis, Spiranthes romanzoffiana and Lycopus uniflorus. Raup and Argus (1982) described a second type that was an interdune lowland forest consisted of Picea mariana, Pinus banksiana, Betula papyrifera, Alnus crispa, Ledum groenlandicum, Goodyera repens, Geocaulon lividum, Empetrum nigrum, Arctostaphylos uva-ursi, and Vaccinium vitis-idaea. Mackenzie River Basin Committee (1981) identified a Pinus banksiana - Ledum groenlandicum community at Lake Athabasca. Important shrubs included Ledum groenlandicum, Vaccinium myrtilloides, and Chamaedaphne calyculata. Mosses included Pleurozium schreberi, Polytrichum juniperinum, and Sphagnum fuscum.

NatureServe (2004) lists a Pinus banksiana / Vaccinium spp. / Pleurozium schreberi Forest (CEGL002441). It occurred on flat to rolling topography and ranges from Maine to Minnesota in the United States and from New Brunswick to Manitoba (Greenall 1996, Zoladeski, et al. 1995). Soils were typically sandy loams, fine sands, and loamy sands. Stands were dominated by Pinus banksiana but may include small amounts of Betula papyrifera, Picea mariana, Pinus resinosa, and Populus tremuloides. Common shrubs included Alnus viridis and Amelanchier alnifolia, and in the midwest Quercus spp. Low shrub cover was significant and consisted of Arctostaphylos uva-ursi, Diervilla lonicera, Juniperus communis, Linnaea borealis, Rosa acicularis, and Vaccinium spp. Common herbs include Aralia nudicaulis, Anemone quinquefolia, Cornus canadensis, Fragaria virginiana, Maianthemum canadense, and Trientalis borealis. Moss cover was dense and consisted mainly of Pleurozium schreberi.

A second similar type listed by NatureServe (2004) is the Pinus banksiana - (Picea mariana, Pinus strobus) / Vaccinium spp. Rocky Woodland (CEGL002483). This type was recorded for Minnesota, Ontario and possibly Quebec. Sites were variable but it usually occurred on shallow, sandy or rocky sites or on talus slopes and bare bedrock to deep mineral soils of coarse to fine sand. Stands had an open canopy consisting of Pinus banksiana and Picea mariana. The shrub layer was open and may have included Picea mariana, Vaccinium angustifolium and Vaccinium myrtilloides. The sparse herb/graminoid consisted of Cornus canadensis, Maianthemum canadense, and Melampyrum lineare. Dicranum polysetum and Pleurozium schreberi formed the moss layer and lichen cover included Cladina rangiferina, Cladina mitis, and Cladina stellaris. 
A third type described by NatureServe (2004) is the Pinus banksiana - Picea mariana / Vaccinium spp. / Pleurozium schreberi Forest (CEGL002448). This latter type occurred across the boreal regions of Canada including Manitoba (Greenall 1996), Ontario, possibly Quebec, and northern portions of the United States. Sites were level to gentle upper and lower slopes. Soils were sands, coarse loams, or silts often with boulders at the surface. The overstorey consisted mainly of Pinus banksiana and Picea mariana was often co-dominant. Some cover of Abies balsamea, Acer rubrum, Picea glauca, and Populus tremuloides may also be common. The shrub layer typically included Alnus viridis, Amelanchier spp., Corylus cornuta, Diervilla lonicera, Gaultheria procumbens, Vaccinium angustifolium, and Vaccinium myrtilloides. The herb layer was sparse consisting of Eurybia macrophylla (= Aster macrophyllus), Clintonia borealis, Cornus canadensis, and Maianthemum canadense. The dense moss layer was dominated by Pleurozium schreberi.

Another related community listed by NatureServe (2004) was the Pinus contorta - (Picea mariana) / Vaccinium vitis-idaea / Hylocomium splendens - Pleurozium schreberi Forest (CEGL002731). This community was widespread in northeastern British Columbia, Alberta, and southwestern Yukon (Allen et al. 2004). Dominants in the overstorey include Pinus contorta var. contorta with Picea mariana. Shrub cover consisted of Ledum groenlandicum with some Rosa acicularis and Vaccinium myrtilloides. Moss cover was dense consisting of Pleurozium schreberi, Hylocomium splendens, and Ptilium crista-castrensis. Similarity ratings for related plant community types are provided in Table 4.

Table 4. Correlation table of plant community types with similarity ratings for the Pinus banksiana / Vaccinium spp. / Pleurozium schreberi type.

\begin{tabular}{|c|c|c|}
\hline Similar Types & $\begin{array}{c}\text { Similarity } \\
\text { Rating } \\
\end{array}$ & Comments \\
\hline $\begin{array}{l}\text { Pinus banksiana / Alnus crispa / Linnaea } \\
\text { borealis - Vaccinium vitis-idaea CT } \\
\text { (Nelson et al. 1989) }\end{array}$ & 2 & $\begin{array}{l}\text { A very similar community type but with a different array } \\
\text { of dominant plant species and higher cover of Alnus } \\
\text { crispa and Vaccinium vitis-idaea. }\end{array}$ \\
\hline $\begin{array}{l}\text { Pinus banksiana / Vaccinium myrtilloides / } \\
\text { Pleurozium schreberi CT (Meijer 2002c) }\end{array}$ & $2(1)$ & $\begin{array}{l}\text { Relatively good fit with the current type in terms of plant } \\
\text { species composition and ground cover. }\end{array}$ \\
\hline $\begin{array}{l}\text { Pinus banksiana / Pleurozium schreberi } \\
\text { CT (Meijer 2002c) }\end{array}$ & $2(3)$ & $\begin{array}{l}\text { Similar species composition but much less cover of } \\
\text { Vaccinium myrtilloides and } V \text {. vitis-idaea. }\end{array}$ \\
\hline $\begin{array}{l}\text { Pinus banksiana (Picea mariana) / Ledum } \\
\text { groenlandicum CT (Raup and Argus 1982) }\end{array}$ & 3 & $\begin{array}{l}\text { A broad type found in ecotones between lowland black } \\
\text { spruce and upland pine stands. It appears to have more } \\
\text { wetland species typical of black spruce/tamarack types. }\end{array}$ \\
\hline $\begin{array}{l}\text { Picea mariana, Pinus banksiana, Betula } \\
\text { papyrifera, Alnus crispa, Ledum } \\
\text { groenlandicum, Vaccinium vitis-idaea } \\
\text { CT(Raup and Argus 1982) }\end{array}$ & 3 & $\begin{array}{l}\text { A lowland forest type that has some similarity to the } \\
\text { current type but no indication that Vaccinium myrtilloides } \\
\text { was an important species and no percent covers were } \\
\text { provided. }\end{array}$ \\
\hline $\begin{array}{l}\text { Pinus banksiana - Ledum groenlandicum } \\
\text { CT (Mackenzie River Basin Comm. 1981) }\end{array}$ & 3 & $\begin{array}{l}\text { Similar type but appears to have higher cover of Ledum } \\
\text { groenlandicum. }\end{array}$ \\
\hline $\begin{array}{l}\text { Pinus banksiana / Vaccinium spp. I } \\
\text { Pleurozium schreberi Forest CEGL002441 } \\
\text { (NatureServe 2004) }\end{array}$ & $3(2)$ & $\begin{array}{l}\text { Reported for northern parts of the midwestern United } \\
\text { States and in central Canada. The floristics was very } \\
\text { similar but included eastern species not found in Alberta. }\end{array}$ \\
\hline $\begin{array}{l}\text { Pinus banksiana - (Picea mariana, Pinus } \\
\text { strobus) /Vaccinium spp. Rocky Woodland } \\
\text { (CEGL002483) (NatureServe 2004) }\end{array}$ & $3(2)$ & $\begin{array}{l}\text { Site conditions may be quite different than those for the } \\
\text { present type. It does not include a deciduous component } \\
\text { and Picea mariana cover was significant. Included } \\
\text { eastern species not found in Alberta (c.g. Pinus strobus). }\end{array}$ \\
\hline $\begin{array}{l}\text { Pinus banksiana - Picea mariana / } \\
\text { Vaccinium } \text { spp. / Pleurozium schreberi } \\
\text { Forest (CEGL002448) (NatureServe 2004) }\end{array}$ & 2 & $\begin{array}{l}\text { A very similar type with many species in common with } \\
\text { the current type but included some eastern species not } \\
\text { indigenous to Alberta. }\end{array}$ \\
\hline $\begin{array}{l}\text { Pinus contorta - (Picea mariana) / } \\
\text { Vaccinium vitis-idaea / Hylocomium } \\
\text { splendens - Pleurozium schreberi Forest } \\
\text { (CEGL002731) (NatureServe 2004) } \\
\end{array}$ & 3 & $\begin{array}{l}\text { This type has a very similar species composition within } \\
\text { the shrub, herb, and moss layer but the dominant tree was } \\
\text { Pinus contorta. The shrub layer has more Ledum } \\
\text { groenlandicum and less Vaccinium spp. }\end{array}$ \\
\hline
\end{tabular}




\subsubsection{Pinus banksiana / Alnus viridis - Vaccinium myrtilloides / Oryzopsis pungens Forest}

Jack Pine / Green Alder - Common Blueberry / Northern Rice Grass Forest

This was a species rich stand type that appears to be common in the Holmes Crossing Sandhills Ecological Reserve (Table 5). No plots were completed in the North Buck Lake study area, however, similar stands may occur there as well. This community occurred on well-drained sites with minimal slope gradients (59\%), subxeric to submesic moisture levels, and a submesotrophic to mesotrophic nutrient regime. Surface substrate cover was mainly organic matter (94\% mean), exposed mineral soil (5\%), and a trace of decaying wood. Pinus banksiana formed a closed (40\%) to moderately open (20\%) overstorey canopy. Important species in the shrub layer were Alnus viridis, Vaccinium myrtilloides, and Arctostaphylos uva-ursi. Other shrubs with high constancy included Prunus virginiana, Amelanchier alnifolia, and Vaccinium vitis-idaea. Oryzopsis pungens and Maianthemum canadense dominated the herb/graminoid layer. Other constant species included Elymus trachycaulus, Erigeron glabellus, Galium boreale, Carex siccata, and Schizachne purpurascens. Moss cover consisted of Pleurozium schreberi at approximately $13 \%$ cover with trace amounts of Dicranum polysetum, and Polytrichum piliferum. Cladina mitis was a constant species but had less than $2 \%$ cover. Cladina rangiferina was often present as well. There was considerable variability in the plots and additional sampling of this type was required to more accurately determine typical percent covers, especially of Oryzopsis pungens.

Class: Forest

Subclass: Evergreen forest

Group: Temperate or subpolar needle-leaved evergreen forest

Subgroup: Natural/Semi-natural

Formation: Rounded-crowned temperate or subpolar needle-leaved evergreen forest

Alliance: Pinus banksiana Forest

Association: Pinus banksiana / Alnus viridis - Vaccinium myrtilloides / Oryzopsis pungens Forest

Unique Identifier: $n / a$

Classification Confidence Level: 1 (Weak) Only two (2) plots completed and there was limited reference to similar types in the literature. Geographical distribution was unknown.

Dominant Species: Pinus banksiana, Alnus viridis, Vaccinium myrtilloides, Maianthemum canadense, Oryzopsis pungens

Co-Dominant Species: Prunus virginiana, Amelanchier alnifolia, Arctostaphylos uva-ursi, Vaccinium vitis-idaea, Elymus trachycaulus, Pleurozium schreberi, Cladina mitis, Cladina rangiferina

Diagnostic Species: Pinus banksiana, Alnus viridis, Vaccinium myrtilloides, Arctostaphylos uva-ursi,, Maianthemum canadense, Erigeron glabellus, Galium boreale, Carex siccata, Schizachne purpurascens, Oryzopsis pungens, Cladina mitis

\section{Literature Review:}

Nelson et al. (1989) described a Pinus banksiana / Arctostaphylos uva-ursi / Cladina spp. community type that occurred in the Holmes Crossing Sandhills Ecological Reserve. The species composition of this type and the current type was virtually identical. However, the current classification had higher constancy and greater percent cover of Alnus viridis, Vaccinium myrtilloides, and Oryzopsis pungens. It also had considerably less cover of Arctostaphylos uva-ursi. A second type identified by Nelson et al. (1989) was a Pinus banksiana - Populus tremuloides / Linnaea borealis - Vaccinium vitis-idaea community. This type was a mixed stand that was more mesic. Mean percent cover values for Alnus viridis, Vaccinium myrtilloides, and Oryzopsis pungens were all substantially lower in this type. Timoney and Robinson (1998) noted a Pinus banksiana / Arctostaphylos uva-ursi / Oryzopsis pungens community type that occurred in Ft. Assiniboine Sandhills Wildland Park. This type was a parkland-like mosaic of dry savannah and jack pine forest. 
Table 5. Summary of plot data and descriptive statistics for the Pinus banksiana / Alnus viridis Vaccinium myrtilloides / Oryzopsis pungens community type $(\mathrm{n}=2)$.

\begin{tabular}{|c|c|c|c|c|c|c|c|c|}
\hline \multirow[b]{2}{*}{ Strata } & \multirow[b]{2}{*}{ Code } & \multirow[b]{2}{*}{ Species } & \multicolumn{2}{|c|}{ Plots } & \multirow[b]{2}{*}{ Mean } & \multirow[b]{2}{*}{ SE } & \multirow[b]{2}{*}{ Constancy } & \multirow[b]{2}{*}{ Prominence } \\
\hline & & & P01 & $\mathbf{P 2 1}$ & & & & \\
\hline $\mathrm{Tl}$ & PINUBAN & Pinus banksiana & 40.0 & 20.0 & 30.0 & 10.0 & 100.0 & 54.8 \\
\hline SI & ALNUVIR & Alnus viridis & 50.0 & 3.0 & 26.5 & 23.5 & 100.0 & 51.5 \\
\hline G & ORYZPUN & Oryzopsis pungens & 3.0 & 30.0 & 16.5 & 13.5 & 100.0 & 40.6 \\
\hline $\mathrm{H}$ & MAIACAN & Maianthemum canadense & 25.0 & 1.0 & 13.0 & 12.0 & 100.0 & 36.1 \\
\hline S3 & VACCMYR & Vaccinium myrtilloides & 9.0 & 9.0 & 9.0 & 0.0 & 100.0 & 30.0 \\
\hline $\mathrm{L}$ & CLADMIT & Cladina mitis & 9.0 & 6.0 & 7.5 & 1.5 & 100.0 & 27.4 \\
\hline S3 & ARCTUVA & Arctostaphylos uva-ursi & 10.0 & 3.0 & 6.5 & 3.5 & 100.0 & 25.5 \\
\hline M & PLEUSCH & Pleurozium schreberi & 25.0 & 0.0 & 12.5 & 12.5 & 50.0 & 25.0 \\
\hline S3 & VACCVIT & Vaccinium vitis-idaea & 15.0 & 0.0 & 7.5 & 7.5 & 50.0 & 19.4 \\
\hline S3 & AMELALN & Amelanchier alnifolia & 0.0 & 10.0 & 5.0 & 5.0 & 50.0 & 15.8 \\
\hline S1 & PRUNVIR & Prunus virginiana & 10.0 & 0.0 & 5.0 & 5.0 & 50.0 & 15.8 \\
\hline G & ELYMTRA & Elymus trachycaulus & 2.0 & 2.0 & 2.0 & 0.0 & 100.0 & 14.1 \\
\hline $\mathrm{L}$ & CLADRAN & Cladina rangiferina & 8.0 & 0.0 & 4.0 & 4.0 & 50.0 & 14.1 \\
\hline S2 & ROSAACI & Rosa acicularis & 6.0 & 0.0 & 3.0 & 3.0 & 50.0 & 12.2 \\
\hline SI & AMELALN & Amelanchier alnifolia & 6.0 & 0.0 & 3.0 & 3.0 & 50.0 & 12.2 \\
\hline $\mathrm{H}$ & ARALNUD & Aralia nudicaulis & 5.0 & 0.0 & 2.5 & 2.5 & 50.0 & 11.2 \\
\hline S3 & PRUNVIR & Prunus virginiana & 0.0 & 4.0 & 2.0 & 2.0 & 50.0 & 10.0 \\
\hline $\mathrm{H}$ & GALIBOR & Galium boreale & 1.0 & 0.1 & 0.6 & 0.5 & 100.0 & 7.4 \\
\hline G & CARESIC & Carex siccata & 0.1 & 1.0 & 0.6 & 0.5 & 100.0 & 7.4 \\
\hline S3 & POPUTRE & Populus tremuloides & 0.0 & 2.0 & 1.0 & 1.0 & 50.0 & 7.1 \\
\hline $\mathrm{E}$ & EPIPHYT & Epiphyte spp. & 0.0 & 2.0 & 1.0 & 1.0 & 50.0 & 7.1 \\
\hline S3 & ROSAACI & Rosa acicularis & 0.0 & 1.0 & 0.5 & 0.5 & 50.0 & 5.0 \\
\hline $\mathrm{H}$ & EPILANG & Epilobium angustifolium & 0.5 & 0.0 & 0.3 & 0.3 & 50.0 & 3.5 \\
\hline S2 & SHEPCAN & Shepherdia canadensis & 0.5 & 0.0 & 0.3 & 0.3 & 50.0 & 3.5 \\
\hline $\mathrm{T} 2$ & PICEGLA & Picea glauca & 0.5 & 0.0 & 0.3 & 0.3 & 50.0 & 3.5 \\
\hline S1 & POPUTRE & Populus tremuloides & 0.5 & 0.0 & 0.3 & 0.3 & 50.0 & 3.5 \\
\hline G & SCHIPUR & Schizachne purpurascens & 0.1 & 0.1 & 0.1 & 0.0 & 100.0 & 3.2 \\
\hline $\mathrm{H}$ & CAMPROT & Campanula rotundifolia & 0.1 & 0.1 & 0.1 & 0.0 & 100.0 & 3.2 \\
\hline $\mathrm{H}$ & ANEMMUL & Anemone multifida & 0.1 & 0.1 & 0.1 & 0.0 & 100.0 & 3.2 \\
\hline $\mathrm{H}$ & ERIGGLA & Erigeron glabellus & 0.1 & 0.1 & 0.1 & 0.0 & 100.0 & 3.2 \\
\hline $\mathrm{H}$ & VIOLADU & Viola adunca & 0.1 & 0.1 & 0.1 & 0.0 & 100.0 & 3.2 \\
\hline $\mathrm{H}$ & ASTELAE & Aster laevis & 0.1 & 0.1 & 0.1 & 0.0 & 100.0 & 3.2 \\
\hline G & FESTSAX & Festuca saximontana & 0.1 & 0.1 & 0.1 & 0.0 & 100.0 & 3.2 \\
\hline G & POAPRAT & Poa pratensis & 0.1 & 0.1 & 0.1 & 0.0 & 100.0 & 3.2 \\
\hline $\mathrm{H}$ & ASTRSTR & Astragalus striatus & 0.1 & 0.1 & 0.1 & 0.0 & 100.0 & 3.2 \\
\hline $\mathrm{H}$ & SOLISPA & Solidago spathulata & 0.1 & 0.1 & 0.1 & 0.0 & 100.0 & 3.2 \\
\hline $\mathrm{H}$ & ARTECAM & Artemisia campestris & 0.1 & 0.1 & 0.1 & 0.0 & 100.0 & 3.2 \\
\hline M & DICRPOL & Dicranum polysetum & 0.1 & 0.0 & 0.1 & 0.1 & 50.0 & 1.6 \\
\hline $\mathrm{H}$ & LILIPHI & Lilium philadelphicum & 0.1 & 0.0 & 0.1 & 0.1 & 50.0 & 1.6 \\
\hline S3 & PRUNPEN & Prunus pensylvanica & 0.0 & 0.1 & 0.1 & 0.1 & 50.0 & 1.6 \\
\hline $\mathrm{M}$ & POLYPIL & Polytrichum piliferum & 0.1 & 0.0 & 0.1 & 0.1 & 50.0 & 1.6 \\
\hline $\mathrm{L}$ & PELTMAL & Peltigera malacea & 0.1 & 0.0 & 0.1 & 0.1 & 50.0 & 1.6 \\
\hline $\mathrm{H}$ & EQUILAE & Equisetum laevigatum & 0.0 & 0.1 & 0.1 & 0.1 & 50.0 & 1.6 \\
\hline G & ELYMINN & Leymus innovatus & 0.0 & 0.1 & 0.1 & 0.1 & 50.0 & 1.6 \\
\hline S3 & RUBUIDA & Rubus idaeus & 0.0 & 0.1 & 0.1 & 0.1 & 50.0 & 1.6 \\
\hline $\mathrm{L}$ & CLADONI & Cladonia spp. & 0.1 & 0.0 & 0.1 & 0.1 & 50.0 & 1.6 \\
\hline S2 & POPUTRE & Populus tremuloides & 0.0 & 0.1 & 0.1 & 0.1 & 50.0 & 1.6 \\
\hline G & CAREUMB & Carex umbellata & 0.0 & 0.1 & 0.1 & 0.1 & 50.0 & 1.6 \\
\hline G & CAREDEW & Carex deweyana & 0.1 & 0.0 & 0.1 & 0.1 & 50.0 & 1.6 \\
\hline M & MOSS\$\$\$ & Unidentified Mosses & 0.0 & 0.1 & 0.1 & 0.1 & 50.0 & 1.6 \\
\hline $\mathrm{H}$ & ARABHOL & Arabis holboellii & 0.0 & 0.1 & 0.1 & 0.1 & 50.0 & 1.6 \\
\hline $\mathrm{H}$ & EQUIHYE & Equisetum hyemale & 0.1 & 0.0 & 0.1 & 0.1 & 50.0 & 1.6 \\
\hline $\mathrm{L}$ & PELTIGE & Peltigera sp. & 0.0 & 0.1 & 0.1 & 0.1 & 50.0 & 1.6 \\
\hline S2 & PRUNVIR & Prunus virginiana & 0.0 & 0.1 & 0.1 & 0.1 & 50.0 & 1.6 \\
\hline $\mathrm{H}$ & ARABDIV & Arabis divaricarpa & 0.1 & 0.0 & 0.1 & 0.1 & 50.0 & 1.6 \\
\hline $\mathrm{H}$ & GENTAMA & Gentianella amarella & 0.0 & 0.1 & 0.1 & 0.1 & 50.0 & 1.6 \\
\hline S2 & SALIBEB & Salix bebbiana & 0.0 & 0.1 & 0.1 & 0.1 & 50.0 & 1.6 \\
\hline $\mathrm{L}$ & PELTCAN & Peltigera canina & 0.1 & 0.0 & 0.1 & 0.1 & 50.0 & 1.6 \\
\hline $\mathrm{H}$ & FRAGVIR & Fragaria virginiana & 0.1 & 0.0 & 0.1 & 0.1 & 50.0 & 1.6 \\
\hline $\mathrm{H}$ & ACHIMIL & Achillea millefolium & 0.1 & 0.0 & 0.1 & 0.1 & 50.0 & 1.6 \\
\hline
\end{tabular}


Allen and Johnson (no date.) described a Pinus banksiana / Alnus crispa community from the Richardson River Dunes Wildland Park. Here it was found at the base of dune ridges.

NatureServe (2004) lists a Pinus banksiana - Populus tremuloides / Diervilla lonicera Forest (CEGL002518) that was found in Minnesota, Ontario, and possibly Quebec and Manitoba. This type occupies level sandy outwash plains or moderately sloping moraines. Stands were generally mixed and dominated by Pinus banksiana and Populus tremuloides with some Abies balsamea, Betula papyrifera, Picea glauca, and Picea mariana. Conifers tend to be more abundant in the northern parts of the range (Sims et al. 1989, Zoladeski et al. 1995). The shrub layer was well developed and included Corylus cornuta, Diervilla lonicera, Linnaea borealis, Rosa acicularis, Rubus pubescens, and Vaccinium spp. The herb layer was diverse and consisted of Aralia nudicaulis, Eurybia macrophylla (=Aster macrophyllus), Cornus canadensis, Clintonia borealis, Streptopus lanceolatus var. longipes (= Streptopus roseus), Trientalis borealis, Viola spp., and other species. Similarity ratings for related plant community types are provided in Table 6.

Table 6. Correlation table of plant community types with similarity ratings for the Pinus banksiana / Alnus viridis - Vaccinium myrtilloides / Oryzopsis pungens type.

\begin{tabular}{||l|c|l||}
\hline \multicolumn{1}{|c|}{ Similar Types } & $\begin{array}{c}\text { Similarity } \\
\text { Rating }\end{array}$ & \multicolumn{1}{|c||}{ Comments } \\
\hline $\begin{array}{l}\text { Pinus banksiana / Arctostaphylos } \\
\text { uva-ursi / Cladina spp. CT (Nelson } \text { et } \\
\text { al. } 1989 \text { ) }\end{array}$ & $2(3)$ & $\begin{array}{l}\text { A similar community type that occupies similar } \\
\text { ecological niche in the Holmes Crossing Sandhills } \\
\text { Ecological Reserve. }\end{array}$ \\
\hline $\begin{array}{l}\text { Pinus banksiana - Populus } \\
\text { tremuloides / Linnaea borealis - } \\
\text { Vaccinium vitis-idaea CT (Nelson } \text { et } \\
\text { al. 1989) }\end{array}$ & 3 & $\begin{array}{l}\text { Although Populus tremuloides was co-dominant in the } \\
\text { overstorey this type has similar species composition. } \\
\text { There are however, considerable differences in species } \\
\text { dominance between these two types. }\end{array}$ \\
\hline $\begin{array}{l}\text { Pinus banksiana / Arctostaphylos } \\
\text { uva-ursi / Oryzopsis pungens CT } \\
\text { (Timoney and Robinson 1998) }\end{array}$ & 2 & $\begin{array}{l}\text { The current classification was likely related to the forest } \\
\text { component of this type, however, no Alnus viridis was } \\
\text { mentioned for this type and additional details regarding } \\
\text { the floristics were required to make a direct comparison. }\end{array}$ \\
\hline $\begin{array}{l}\text { Pinus banksiana / Alnus crispa CT } \\
\text { (Allen and Johnson no date) }\end{array}$ & 3 & $\begin{array}{l}\text { Same dominant tree and shrub but no further details were } \\
\text { provided for this type to allow a better comparison. }\end{array}$ \\
\hline $\begin{array}{l}\text { Pinus banksiana } \text { - Populus } \\
\text { tremuloides / Diervilla lonicera } \\
\text { Forest (CEGL002518) (NatureServe } \\
\text { 2004) }\end{array}$ & 3 & $\begin{array}{l}\text { This type appears to occupy sites with similar ecological } \\
\text { conditions. However, stands were mixed and there were } \\
\text { considerable differences in floristics. This community } \\
\text { included many eastern species. }\end{array}$ \\
\hline
\end{tabular}




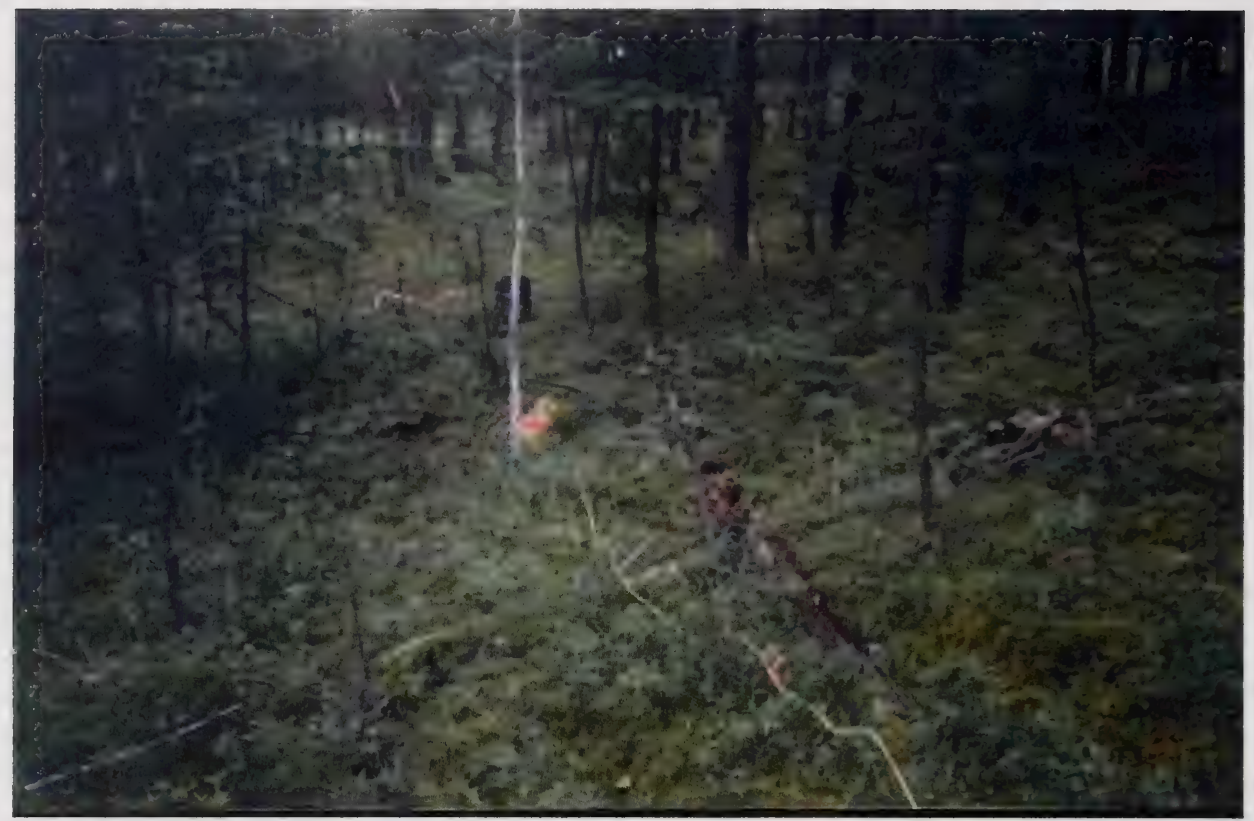

Plate 2. Pinus banksiana / Vaccinium spp. / Pleurozium schreberi Forest (P43).

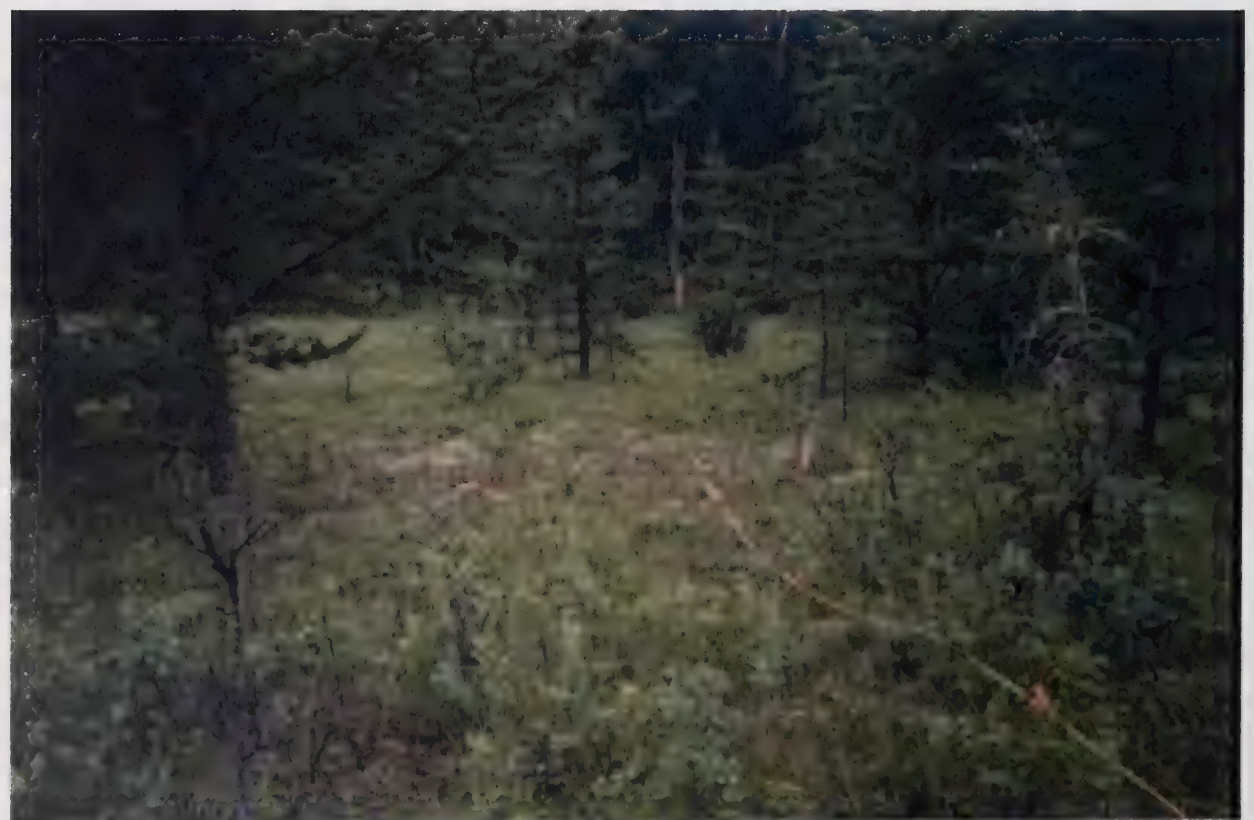

Plate 3. Pinus banksiana / Alnus viridis / Oryzopsis pungens Forest (P21). 


\subsubsection{Pinus banksiana / Arctostaphylos uva-ursi / Apocynum androsaemifolium Forest}

Jack Pine / Common Bearberry / Spreading Dogbane Forest

This plant community was not encountered in the North Buck Lake study area but two samples were completed in the Holmes Crossing Sandhills Ecological Reserve where it was relatively common. It typically occurred on south facing upper slopes and crests of dunes. Soils consist of fine sands that were well to rapidly drained and had subxeric to submesic moisture levels with a mesotrophic nutrient regime. Moderate levels of insolation affected sites. The surface substrate cover consisted of organic matter (94\%), mineral soil (3\%), and decaying wood (1\%). The overstorey canopy was quite open, averaging $23 \%$ closure consisting of Pinus banksiana and scattered Populus tremuloides trees (Table 7). The shrub layer consisted of scattered Alnus viridis with less than $11 \%$ cover. Constant species diagnostic of this community include Apocynum androsaemifolium and Arctostaphylos uva-ursi at $7 \%$ and $45 \%$ mean cover, respectively. Other shrubs associated with this type include Amelanchier alnifolia, Rosa acicularis and Prunus virginiana. Usnea spp. was present in both plots and averaged $33 \%$ cover. Common forbs included Lathyrus ochroleucus, Smilacina stellata, Lilium philadelphicum, Smilacina stellata, Maianthemum canadense, Solidago spathulata, Galium boreale, Anemone multifida Astragalus striatus, and Aster laevis. Graminoids associated with this type include Oryzopsis pungens Carex umbellata and Elymus trachycaulus.

Class: Forest

Subclass: Evergreen forest

Group: Temperate or subpolar needle-leaved evergreen forest

Subgroup: Natural/Semi-natural

Formation: Rounded-crowned temperate or subpolar needle-leaved evergreen forest

Alliance: Pinus banksiana Forest

Association: Pinus banksiana / Arctostaphylos uva-ursi / Apocynum androsaemifolium Forest

Unique Identifier: $n / a$

Classification Confidence Level: 3 (Weak) Although this community appeared to be relatively common in the Holmes Crossing area there were only two plots completed and no reference to this type was located literature. The geographic distribution of this community was unknown.

Dominant Species: Pinus banksiana, Alnus viridis, Arctostaphylos uva-ursi, Apocynum androsaemifolium, Usnea spp.

Co-Dominant Species: Populus tremuloides, Amelanchier alnifolia, Rosa acicularis, Lathyrus ochroleucus, Smilacina stellata, Oryzopsis pungens

Diagnostic Species: Pinus banksiana, Alnus viridis, Amelanchier alnifolia, Arctostaphylos uva-ursi, Apocynum androsaemifolium, Lilium philadelphicum, Carex umbellata

\section{Literature Review:}

Nelson et al. (1989) described a Pinus banksiana / Arctostaphylos uva-ursi / Cladina mitis community occurring in the Holmes Crossing area. It was similar to the current type but does not have any Apocynum androsaemifolium cover.

Raup and Argus (1982) provide a broad description of a Pinus banksiana forest in the Lake Athabasca area that often included Picea mariana and Betula papyrifera, as co-dominants. Common shrub species included Alnus crispa, Salix scouleriana, Viburnum edule, Ledum groenlandicum, Empetrum nigrum, Arctostaphylos uva-ursi, and Vaccinium vitis-idaea. Common herb layer species included Lycopodium annotinum, L. sitchense, Goodyera repens, Lathyrus ochroleucus, Vicia americana, Cornus canadensis, Apocynum androsaemifolium, and Melampyrum lineare. 
Table 7. Summary of plot data and descriptive statistics for the Pinus banksiana / Arctostaphylos uva-ursi / Apocynum androsaemifolium community type $(\mathrm{n}=2)$.

\begin{tabular}{|c|c|c|c|c|c|c|c|c|}
\hline \multirow[b]{2}{*}{ Strata } & \multirow[b]{2}{*}{ Code } & \multirow[b]{2}{*}{ Species } & \multicolumn{2}{|c|}{ Plots } & \multirow[b]{2}{*}{ Mean } & \multirow[b]{2}{*}{ SE } & \multirow[b]{2}{*}{ Constancy } & \multirow[b]{2}{*}{ Prominence } \\
\hline & & & P26 & P28 & & & & \\
\hline S3 & ARCTUVA & Arctostaphylos uva-ursi & 30.0 & 60.0 & 45.0 & 15.0 & 100.0 & 67.1 \\
\hline $\mathrm{E}$ & USNEA\$\$\$ & Usnea spp. & 60.0 & 5.0 & 32.5 & 27.5 & 100.0 & 57.0 \\
\hline $\mathrm{Tl}$ & PINUBAN & Pinus banksiana & 25.0 & 20.0 & 22.5 & 2.5 & 100.0 & 47.4 \\
\hline $\mathrm{E}$ & EPIPHYT & Epiphyte spp. & 10.0 & 5.0 & 7.5 & 2.5 & 100.0 & 27.4 \\
\hline SI & ALNUVIR & Alnus viridis & 3.0 & 10.0 & 6.5 & 3.5 & 100.0 & 25.5 \\
\hline $\mathrm{H}$ & APOCAND & Apocynum androsaemifolium & 8.0 & 5.0 & 6.5 & 1.5 & 100.0 & 25.5 \\
\hline S3 & AMELALN & Amelanchier alnifolia & 5.0 & 1.0 & 3.0 & 2.0 & 100.0 & 17.3 \\
\hline $\mathrm{T} 2$ & POPUTRE & Populus tremuloides & 0.1 & 2.0 & 1.1 & 1.0 & 100.0 & 10.2 \\
\hline S3 & ROSAACI & Rosa acicularis & 2.0 & 0.1 & 1.1 & 1.0 & 100.0 & 10.2 \\
\hline G & ORYZPUN & Oryzopsis pungens & 1.0 & 1.0 & 1.0 & 0.0 & 100.0 & 10.0 \\
\hline $\mathrm{H}$ & LATHOCH & Lathyrus ochroleucus & 1.0 & 1.0 & 1.0 & 0.0 & 100.0 & 10.0 \\
\hline $\mathrm{H}$ & SMILSTE & Smilacina stellata & 1.0 & 1.0 & 1.0 & 0.0 & 100.0 & 10.0 \\
\hline $\mathrm{H}$ & MAIACAN & Maianthemum canadense & 0.1 & 1.0 & 0.6 & 0.5 & 100.0 & 7.4 \\
\hline $\mathrm{H}$ & SOLISPA & Solidago spathulata & 1.0 & 0.1 & 0.6 & 0.5 & 100.0 & 7.4 \\
\hline $\mathrm{H}$ & GALIBOR & Galium boreale & 1.0 & 0.1 & 0.6 & 0.5 & 100.0 & 7.4 \\
\hline S3 & PRUNVIR & Prunus virginiana & 1.0 & 0.1 & 0.6 & 0.5 & 100.0 & 7.4 \\
\hline $\mathrm{T} 1$ & POPUTRE & Populus tremuloides & 2.0 & 0.0 & 1.0 & 1.0 & 50.0 & 7.1 \\
\hline $\mathrm{H}$ & LILIPHI & Lilium philadelphicum & 0.1 & 0.1 & 0.1 & 0.0 & 100.0 & 3.2 \\
\hline G & CAREUMB & Carex umbellata & 0.1 & 0.1 & 0.1 & 0.0 & 100.0 & 3.2 \\
\hline $\mathrm{H}$ & ANEMMUL & Anemone multifida & 0.1 & 0.1 & 0.1 & 0.0 & 100.0 & 3.2 \\
\hline $\mathrm{H}$ & ASTRSTR & Astragalus striatus & 0.1 & 0.1 & 0.1 & 0.0 & 100.0 & 3.2 \\
\hline $\mathrm{H}$ & ASTELAE & Aster laevis & 0.1 & 0.1 & 0.1 & 0.0 & 100.0 & 3.2 \\
\hline G & ELYMTRA & Elymus trachycaulus & 0.1 & 0.1 & 0.1 & 0.0 & 100.0 & 3.2 \\
\hline S1 & PINUBAN & Pinus banksiana & 0.1 & 0.0 & 0.1 & 0.1 & 50.0 & 1.6 \\
\hline M & MOSS\$\$ $\$$ & Moss spp. & 0.0 & 0.1 & 0.1 & 0.1 & 50.0 & 1.6 \\
\hline S3 & LINNBOR & Linnaea borealis & 0.0 & 0.1 & 0.1 & 0.1 & 50.0 & 1.6 \\
\hline S3 & VACCVIT & Vaccinium vitis-idaea & 0.0 & 0.1 & 0.1 & 0.1 & 50.0 & 1.6 \\
\hline S3 & RUBUIDA & Rubus idaeus & 0.1 & 0.0 & 0.1 & 0.1 & 50.0 & 1.6 \\
\hline G & ELYMINN & Leymus innovatus & 0.1 & 0.0 & 0.1 & 0.1 & 50.0 & 1.6 \\
\hline $\mathrm{L}$ & CLADMIT & Cladina mitis & 0.0 & 0.1 & 0.1 & 0.1 & 50.0 & 1.6 \\
\hline S3 & SYMPOCC & Symphoricarpos occidentalis & 0.0 & 0.1 & 0.1 & 0.1 & 50.0 & 1.6 \\
\hline $\mathrm{H}$ & HIERUMB & Hieracium umbellatum. & 0.0 & 0.1 & 0.1 & 0.1 & 50.0 & 1.6 \\
\hline $\mathrm{H}$ & ARTECAM & Artemisia campestris & 0.1 & 0.0 & 0.1 & 0.1 & 50.0 & 1.6 \\
\hline S3 & POPUTRE & Populus tremuloides & 0.0 & 0.1 & 0.1 & 0.1 & 50.0 & 1.6 \\
\hline S3 & PRUNPEN & Prunus pensylvanica & 0.0 & 0.1 & 0.1 & 0.1 & 50.0 & 1.6 \\
\hline $\mathrm{T} 2$ & PICEGLA & Picea glauca & 0.1 & 0.0 & 0.1 & 0.1 & 50.0 & 1.6 \\
\hline G & CAREPEN & Carex pensylvanica & 0.1 & 0.0 & 0.1 & 0.1 & 50.0 & 1.6 \\
\hline $\mathrm{H}$ & CAMPROT & Campanula rotundifolia & 0.0 & 0.1 & 0.1 & 0.1 & 50.0 & 1.6 \\
\hline M & PLEUSCH & Pleurozium schreberi & 0.1 & 0.0 & 0.1 & 0.1 & 50.0 & 1.6 \\
\hline
\end{tabular}

NatureServe (2004) lists a Pinus banksiana / Arctostaphylos uva-ursi Forest (CEGL002438) that occurred in the midwestern United States and central Canada including Manitoba (Greenall 1996). This type has similarities in composition and structure but included species not found in the study areas and does not include Apocynum androsaemifolium as a diagnostic species. Similarity ratings for related plant community types are provided in Table 8. 
Table 8. Correlation table of plant community types with similarity ratings for the Pinus banksiana / Apocynum androsaemifolium - Arctostaphylos uva-ursi type.

\begin{tabular}{||l|c|l||}
\hline \multicolumn{1}{|c|}{ Similar Types } & $\begin{array}{c}\text { Similarity } \\
\text { Rating }\end{array}$ & \multicolumn{1}{|c||}{ Comments } \\
\hline \hline $\begin{array}{l}\text { Pinus banksiana / Arctostaphylos } \\
\text { uva-ursi / Cladina mitis CT (Nelson } \\
\text { et al. } \text { 1989) }\end{array}$ & $3(2)$ & $\begin{array}{l}\text { Similar dominant species in this type but Cladina mitis } \\
\text { cover was higher and Apocynum androsaemifolium was } \\
\text { not listed as an important species. }\end{array}$ \\
\hline $\begin{array}{l}\text { Pinus banksiana Forest (Raup and } \\
\text { Argus 1982) }\end{array}$ & 2 & $\begin{array}{l}\text { Slightly moister Lake Athabasca dune community but } \\
\text { included many of the same plant species. Apocynum } \\
\text { androsaemifolium was present but there were no details } \\
\text { available regarding percent covers. }\end{array}$ \\
\hline $\begin{array}{l}\text { Pinus banksiana / Arctostaphylos } \\
\text { uva-ursi Forest (CEGL002438) } \\
\text { (NatureServe 2004) }\end{array}$ & 3 & $\begin{array}{l}\text { Similar community but the description does not indicate } \\
\text { that Apocynum androsaemifolium } \text { was a constant } \\
\text { species. }\end{array}$ \\
\hline
\end{tabular}

\subsubsection{Pinus banksiana /Vaccinium vitis-idaea - Arctostaphylos uva-ursi Forest} Jack Pine / Bog Cranberry - Common Bearberry Forest

This community was not common and only one (1) plot was completed for it in the North Buck Lake study area (Table 9). This site was located in a nearly level to slight depression. Soils were well drained with mesic moisture levels and a mesotrophic nutrient regime. The substrate cover consisted mainly of organic matter (98\%) with decaying wood (2\%) and a trace of mineral soil. This stand had a closed canopy of Pinus banksiana and no medium or tall shrub layers. Cover in the low shrub layer consisted of Vaccinium vitis-idaea (30\%), Vaccinium myrtilloides (25\%), Arctostaphylos uva-ursi (3\%), and Rosa acicularis (1\%). The herb/graminoid layer was sparse with less than $3 \%$ cover consisting of Maianthemum canadense, Medicago lupulina, Oryzopsis pungens, Pyrola chlorantha, Schizachne purpurascens, and Hieracium umbellatum. The moss layer had less than $17 \%$ cover consisting mainly of Pleurozium schreberi. Cladina mitis was present in trace amounts. This stand type may grade into a Pinus banksiana / Arctostaphylos uva-ursi Forest on drier sites or a Pinus banksiana / Vaccinium myrtilloides - Vaccinium vitis-idaea / Pleurozium schreberi Forest on moister sites.

Class: Forest

Subclass: Evergreen forest

Group: Temperate or subpolar needle-leaved evergreen forest

Subgroup: Natural/Semi-natural

Formation: Rounded-crowned temperate or subpolar needle-leaved evergreen forest

Alliance: Pinus banksiana Forest

Association: Pinus banksiana / Vaccinium vitis-idaea - Arctostaphylos uva-ursi Forest

Unique Identifier: $n / a$

Classification Confidence Level: 2 (Moderate) Only one plot was completed in this type and there was considerable variability in the published literature. Geographical distribution was uncertain.

Dominant Species: Pinus banksiana, Vaccinium vitis-idaea, Arctostaphylos uva-ursi, Pleurozium schreberi

Co-Dominant Species: Rosa acicularis, Vaccinium myrtilloides, Maianthemum canadense, Cladina mitis, Usnea spp

Diagnostic Species: Pinus banksiana, Vaccinium vitis-idaea, Vaccinium myrtilloides, Arctostaphylos uvaursi, Pleurozium schreberi 
Table 9. Summary of plot data and descriptive statistics for the Pinus banksiana / Vaccinium vitis-idaea Arctostaphylos uva-ursi community type $(\mathrm{n}=1)$.

\begin{tabular}{|cllc|}
\hline & & & Plot \\
\cline { 4 - 4 } Strata & Code & \multicolumn{1}{c|}{ Species } & P41 \\
\hline T1 & PINUBAN & Pinus banksiana & 40.0 \\
S3 & VACCVIT & Vaccinium vitis-idaea & 30.0 \\
S3 & ARCTUVA & Arctostaphylos uva-ursi & 25.0 \\
M & PLEUSCH & Pleurozium schreberi & 16.0 \\
E & USNEA\$\$\$ & Usnea spp. & 5.0 \\
S3 & VACCMYR & Vaccinium myrtilloides & 3.0 \\
L & CLADMIT & Cladina mitis & 1.0 \\
H & MAIACAN & Maianthemum & 1.0 \\
S3 & ROSAACI & Ranadense & 1.0 \\
H & MELALIN & Medicagolaris & 0.1 \\
G & ORYZPUN & Oryzopsis pungens & 0.1 \\
\hline
\end{tabular}

\begin{tabular}{|c|c|c|c|}
\hline & & & Plot \\
\hline Strata & Code & Species & P41 \\
\hline S3 & PRUNPEN & Prunus pensylvanica & 0.1 \\
\hline M & PTILCRI & Ptilium crista-castrensis & 0.1 \\
\hline M & POLYPIL & Polytrichum piliferum & 0.1 \\
\hline M & DICRPOL & Dicranum polysetum & 0.1 \\
\hline $\mathrm{H}$ & PYROCHL & Pyrola chlorantha & 0.1 \\
\hline $\mathrm{H}$ & CAMPROT & Campanula rotundifolia & 0.1 \\
\hline G & SCHIPUR & $\begin{array}{l}\text { Schizachne } \\
\text { purpurascens }\end{array}$ & 0.1 \\
\hline L & CLADGRA & Cladonia gracilis & 0.1 \\
\hline $\mathrm{H}$ & HIERUMB & Hieracium umbellatum & 0.1 \\
\hline S3 & PINUBAN & Pinus banksiana & 0.1 \\
\hline S1 & PINUBAN & Pinus banksiana & 0.1 \\
\hline
\end{tabular}

\section{Literature Review:}

Allen et al. (2003) reported a Pinus banksiana / Vaccinium vitis-idaea / Cladonia spp. community type that occurred in the Fidler-Greywillow Provincial Park at Lake Athabasca. It was widespread on stabilised dunes and sandy plains, and was considered an early stage of the Pinus banksiana / Cladina spp. type.

Beckingham and Archibald (1996) identified a Pinus banksiana - Populus tremuloides / Vaccinium myrtilloides - Arctostaphylos uva-ursi forest (b1.1) for the boreal mixedwood. This community was similar to the current type but Populus tremuloides, and P. mariana were co-dominant in the overstorey and Picea glauca was present in the shrub layer. There was also greater cover of Vaccinium myrtilloides and Cladina spp. in the b1.1 type. Another difference was the absence of Leymus innovatus and Hylocomium splendens in the North Buck Lake plot. Beckingham and Archibald (1996) also described a Pinus banksiana / Arctostaphylos uva-ursi / Cladina mitis plant community type (a.1.1). This boreal mixedwood type was similar to the current type but has higher cover of Arctostaphylos uva-ursi $(\geq 20 \%)$ in contrast to trace amounts found in the current type. Otherwise cover of other the dominant and diagnostic species was similar.

Alberta Energy and Natural Resources (1978a, 1978b) reported a Pinus banksiana / Arctostaphylos uvaursi forest occurred in the Wapiti - Grande Prairie sand dunes area. This type occurred on fine to medium sandy soils that were rapidly drained. No additional details regarding plant composition were provided.

NatureServe (2004) lists a Pinus banksiana / Arctostaphylos uva-ursi Forest (CEGL002438) for the midwestern United States and central Canada, including Manitoba (Zoladeski et al. 1995). It occurred on eolian, glaciofluvial, lacustrine, and morainal deposits. Soils were typically sand, loamy sand, or sandy loam. The overstorey consisted of Pinus banksiana with some Pinus resinosa, Populus tremuloides, and Picea mariana in stands adjacent to wet areas. The shrub layer included Amelanchier alnifolia, Arctostaphylos uva-ursi, Diervilla lonicera, Hudsonia tomentosa, and Vaccinium spp. Herbs consist of Aster laevis, Cornus canadensis, Maianthemum canadense, Oryzopsis asperifolia, and Solidago spp. In the absence of fire these stands may succeed to Abies balsamea, Picea glauca and Picea mariana. Mosses 
were common on mesic sites. A related mixed stand type was the Pinus banksiana - Populus tremuloides Picea mariana / Pleurozium schreberi Forest (CEGL002519) was ranked GNR. This type occurred in Manitoba (Greenall 1996) and Ontario (Sims et al. 1989) but no details were available for this review. Similarity ratings for related plant community types are provided in Table 10.

Table 10. Correlation table of plant community types with similarity ratings for the Pinus banksiana / Vaccinium vitis-idaea - Arctostaphylos uva-ursi type.

\begin{tabular}{||l|c|l||}
\hline \multicolumn{1}{|c|}{ Similar Types } & $\begin{array}{c}\text { Similarity } \\
\text { Rating }\end{array}$ & \multicolumn{1}{c||}{ Comments } \\
\hline \hline $\begin{array}{l}\text { Pinus banksiana/Vaccinium vitis- } \\
\text { idaea/Cladonia } \text { CT(Allen } \text { et al. 2003) }\end{array}$ & 2 & $\begin{array}{l}\text { Similar type although it appears that Arctostaphylos } \\
\text { uva-ursi cover was lower and Cladonia gracilis cover } \\
\text { was much higher in this type. }\end{array}$ \\
\hline $\begin{array}{l}\text { Pinus banksiana - Populus tremuloides / } \\
\text { Vaccinium myrtilloides - Arctostaphylos } \\
\text { uva-ursi CT (b1.1) (Beckingham and } \\
\text { Archibald 1996) }\end{array}$ & 2 & $\begin{array}{l}\text { Overstorey was more mixed and included Populus } \\
\text { tremuloides and Picea mariana in this type. Dwarf } \\
\text { shrub layer was similar but Vaccinium myrtilloides } \\
\text { cover was greater. }\end{array}$ \\
\hline $\begin{array}{l}\text { Pinus banksiana / Arctostaphylos } \text { uva- } \\
\text { ursi / Cladina } \text { spp. CT (a.1.1) } \\
\text { (Beckingham and Archibald 1996) }\end{array}$ & $2(3)$ & $\begin{array}{l}\text { Similar but much more Cladina spp., Vaccinium vitis- } \\
\text { idaea was not a dominant species, and Pleurozium } \\
\text { schreberi had less cover in this type. }\end{array}$ \\
\hline $\begin{array}{l}\text { Pinus banksiana / Arctostaphylos uva- } \\
\text { ursi Forest (CEGL002438) (Zoladeski } \text { et } \\
\text { al. } \text { 1995, NatureServe 2004) }\end{array}$ & $3(2)$ & $\begin{array}{l}\text { Similar type but may be drier and does not appear to } \\
\text { have significant cover of Vaccinium vitis-idaea. } \\
\text { Included eastern species not native to Alberta. }\end{array}$ \\
\hline $\begin{array}{l}\text { Pinus banksiana } \text { - Populus tremuloides - } \\
\text { Picea mariana / Pleurozium schreberi } \\
\text { Forest (CEGL002519) (NatureServe } \\
\text { 2004, Sims } \text { et al. } \text { 1989) }\end{array}$ & 3 & Similar type but no details were available for review. \\
\hline
\end{tabular}




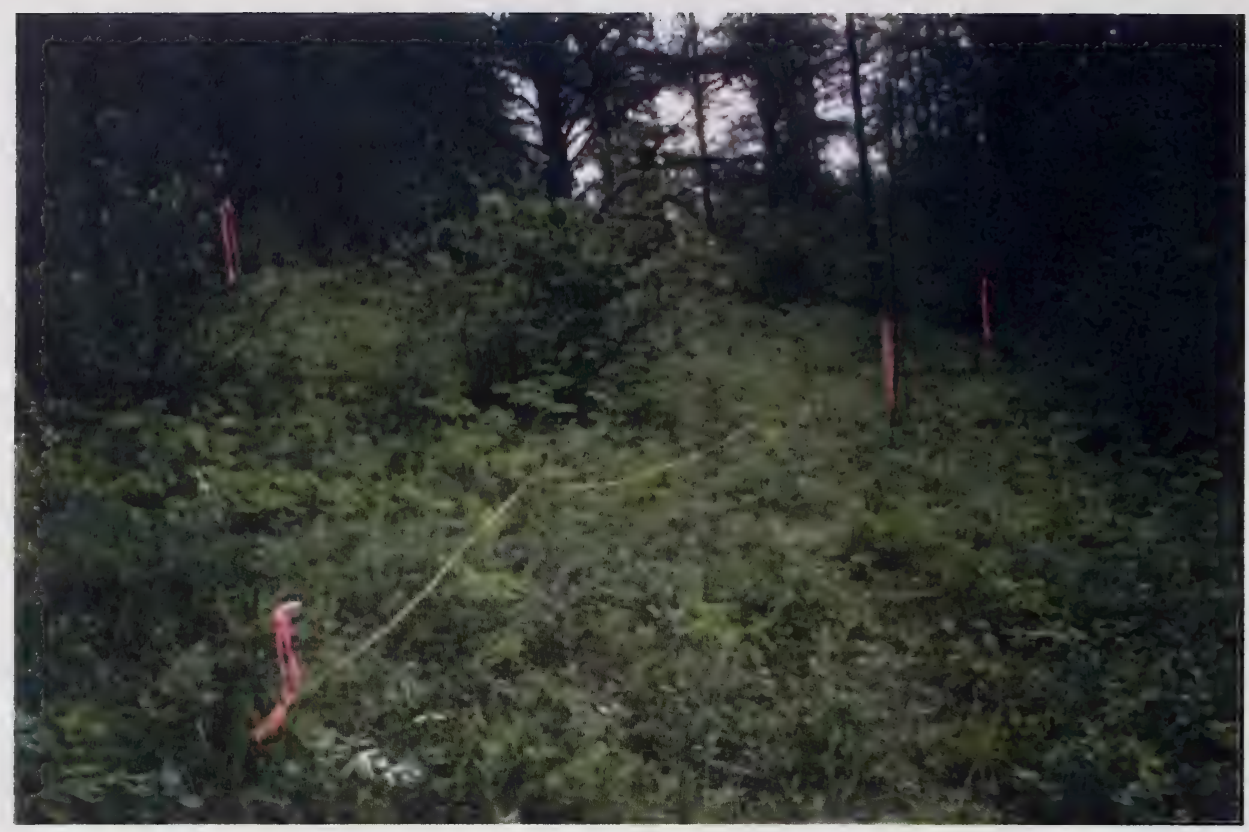

Plate 4. Pinus banksiana / Arctostaphylos uva-ursi / Apocynum androsaemifolium Forest (P26).

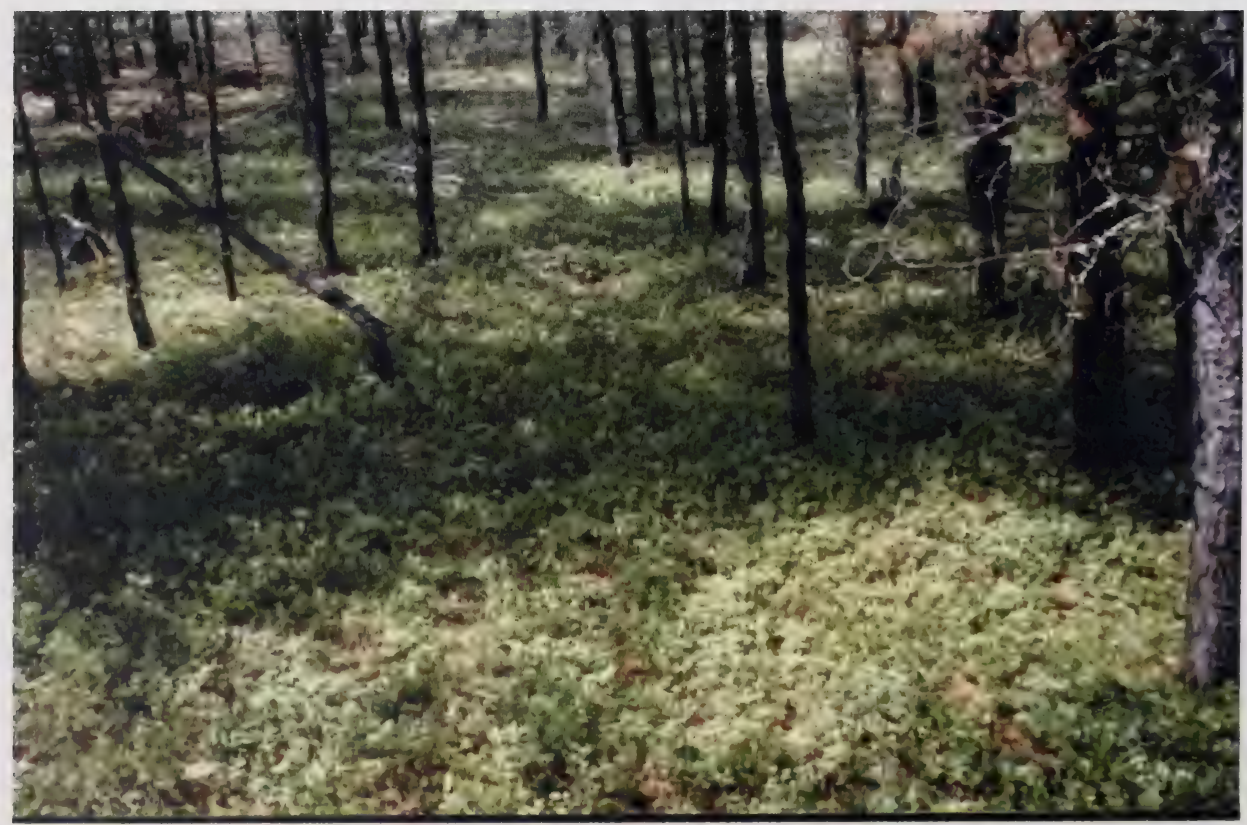

Plate 5. Pinus banksiana /Vaccinium vitis-idaea - Arctostaphylos uva-ursi Forest (P41). 


\subsubsection{Pinus banksiana / Cladina mitis Forest}

Jack Pine - Reindeer Lichen Forest

The Pinus banksiana / Cladina mitis Forest was a very distinctive stand with usually $60 \%$ to $70 \%$ percent ground cover of Cladina spp. This community was sampled in both study areas but was encountered more frequently in the North Buck Lake study area (Table 11). Stands were located typically in crest to level site positions that commonly had convex to straight profiles with minimal slope gradients (3-10\%). The sandy soils were well to rapidly drained with subxeric moisture conditions, and a mesotrophic nutrient regime. Surface substrate cover was predominately organic matter with some exposed soil (1-10\%), and traces of decaying wood. The overstorey was dominated by Pinus banksiana with $20 \%$ to $40 \%$ canopy closure. There was no medium or tall shrub layer and the low shrub layer had less than $5 \%$ cover consisting of Vaccinium myrtilloides, Arctostaphylos uva-ursi, Rosa acicularis, and Pinus banksiana. The herb/graminoid layer was sparse and species with high constancy included Maianthemum canadense, Medicago lupulina, Solidago spathulata, and Oryzopsis pungens. Other important species included Hudsonia tomentosa and Campanula rotundifolia. Mosses with high constancy included Polytrichum piliferum and Pohlia nutans. The most common lichens were Cladina mitis, Cladonia gracilis and a variety of Cladonia spp.

Class: Forest

Subclass: Evergreen forest

Group: Temperate or subpolar needle-leaved evergreen forest

Subgroup: Natural/Semi-natural

Formation: Rounded-crowned temperate or subpolar needle-leaved evergreen forest

Alliance: Pinus banksiana Forest

Association: Pinus banksiana / Cladina mitis Forest

Unique Identifier: $\mathrm{n} / \mathrm{a}$

Classification Confidence Level: 1 (Strong) This was very distinctive type and that was relatively well documented in the literature. Appears to be widespread throughout the boreal region but exact geographic range was uncertain.

Dominant Species: Pinus banksiana, Cladina mitis

Co-Dominant Species: Vaccinium vitis-idaea, Vaccinium myrtilloides, Maianthemum canadense, Polytrichum piliferum, Cladonia gracilis

Diagnostic Species: Pinus banksiana, Cladina mitis, Arctostaphylos uva-ursi, Maianthemum canadense, Medicago lupulina, Solidago spathulata, Oryzopsis pungens

\section{Literature Review:}

The Pinus banksiana / Cladina mitis community type was similar to the Pinus banksiana / Arctostaphylos uva-ursi / Cladina mitis community type described by Nelson et al. (1989). This latter type occurred on sand plains and dunes in the Holmes Crossing study area. The plant community composition of this type was similar, however, the percent cover of Arctostaphylos uva-ursi was a higher and Cladina mitis cover was significantly lower.

Allen et al. (2003) reported a Pinus banksiana / Vaccinium myrtilloides / Cladina mitis community type from the Fidler-Greywillow Provincial Park at Lake Athabasca. It was recognised as a widespread type that occurred on stabilised dunes and sandy dunes. Allen et al. (2002) reported a Pinus banksiana / Arctostaphylos uva-ursi community type from the La Butte Creek Provincial Park in northeastern Alberta. It typically had significant lichen cover and occurred as small stands on flatter sites among outcrops. 
Table 11. Summary of plot data and descriptive statistics for the Pinus banksiana / Cladina mitis community type $(n=3)$.

\begin{tabular}{|c|c|c|c|c|c|c|c|c|c|}
\hline \multirow[b]{2}{*}{ Strata } & \multirow[b]{2}{*}{ Code } & \multirow[b]{2}{*}{ Species } & \multicolumn{3}{|c|}{ Plots } & \multirow[b]{2}{*}{ Mean } & \multirow[b]{2}{*}{ SE } & \multirow[b]{2}{*}{ Constancy } & \multirow[b]{2}{*}{ Prominence } \\
\hline & & & P06 & $\mathbf{P 4 0}$ & P42 & & & & \\
\hline L & CLADMIT & Cladina mitis & 70.0 & 70.0 & 60.0 & 66.7 & 3.3 & 100.0 & 81.6 \\
\hline $\mathrm{T} 1$ & PINUBAN & Pinus banksiana & 20.0 & 38.0 & 40.0 & 32.7 & 6.4 & 100.0 & 57.2 \\
\hline $\mathrm{E}$ & USNEA\$\$\$ & Usnea spp. & 0.0 & 25.0 & 0.0 & 8.3 & 8.3 & 33.3 & 16.7 \\
\hline M & PLEUSCH & Pleurozium schreberi & 15.0 & 0.0 & 0.0 & 5.0 & 5.0 & 33.3 & 12.9 \\
\hline $\mathrm{H}$ & MAIACAN & Maianthemum canadense & 3.0 & 0.1 & 0.1 & 1.1 & 1.0 & 100.0 & 10.3 \\
\hline $\mathrm{S} 3$ & VACCVIT & Vaccinium vitis-idaea & 9.0 & 0.0 & 0.0 & 3.0 & 3.0 & 33.3 & 10.0 \\
\hline S3 & VACCMYR & Vaccinium myrtilloides & 4.0 & 0.1 & 0.0 & 1.4 & 1.3 & 66.7 & 9.5 \\
\hline $\mathrm{L}$ & CLADGRA & Cladonia gracilis & 0.1 & 3.0 & 0.0 & 1.0 & 1.0 & 66.7 & 8.3 \\
\hline $\mathrm{S} 1$ & PINUBAN & Pinus banksiana & 0.0 & 1.0 & 2.0 & 1.0 & 0.6 & 66.7 & 8.2 \\
\hline $\mathrm{E}$ & EPIPHYT & Epiphyte spp. & 0.0 & 5.0 & 0.0 & 1.7 & 1.7 & 33.3 & 7.5 \\
\hline S3 & ARCTUVA & Arctostaphylos uva-ursi & 1.0 & 0.1 & 0.1 & 0.4 & 0.3 & 100.0 & 6.3 \\
\hline $\mathrm{M}$ & POLYPIL & Polytrichum piliferum & 0.0 & 0.1 & 1.0 & 0.4 & 0.3 & 66.7 & 4.9 \\
\hline S3 & ROSAACI & Rosa acicularis & 1.0 & 0.0 & 0.0 & 0.3 & 0.3 & 33.3 & 3.3 \\
\hline S3 & PINUBAN & Pinus banksiana & 0.1 & 0.1 & 0.1 & 0.1 & 0.0 & 100.0 & 3.2 \\
\hline G & ORYZPUN & Oryzopsis pungens & 0.1 & 0.1 & 0.1 & 0.1 & 0.0 & 100.0 & 3.2 \\
\hline $\mathrm{H}$ & SOLISPA & Solidago spathulata & 0.1 & 0.1 & 0.1 & 0.1 & 0.0 & 100.0 & 3.2 \\
\hline $\mathrm{H}$ & MELALIN & Medicago lupulina & 0.1 & 0.1 & 0.1 & 0.1 & 0.0 & 100.0 & 3.2 \\
\hline $\mathrm{H}$ & HUDSTOM & Hudsonia tomentosa & 0.0 & 0.1 & 0.1 & 0.1 & 0.0 & 66.7 & 2.1 \\
\hline M & POHLNUT & Pohlia nutans & 0.1 & 0.1 & 0.0 & 0.1 & 0.0 & 66.7 & 2.1 \\
\hline $\mathrm{H}$ & CAMPROT & Campanula rotundifolia & 0.1 & 0.0 & 0.1 & 0.1 & 0.0 & 66.7 & 2.1 \\
\hline M & DICRPOL & Dicranum polysetum & 0.0 & 0.0 & 0.1 & 0.0 & 0.0 & 33.3 & 1.1 \\
\hline $\mathrm{H}$ & ANEMMUL & Anemone multifida & 0.1 & 0.0 & 0.0 & 0.0 & 0.0 & 33.3 & 1.1 \\
\hline M & PTILCRI & Ptilium crista-castrensis & 0.1 & 0.0 & 0.0 & 0.0 & 0.0 & 33.3 & 1.1 \\
\hline S3 & PICEGLA & Picea glauca & 0.1 & 0.0 & 0.0 & 0.0 & 0.0 & 33.3 & 1.1 \\
\hline $\mathrm{H}$ & HIERUMB & Hieracium umbellatum & 0.1 & 0.0 & 0.0 & 0.0 & 0.0 & 33.3 & 1.1 \\
\hline $\mathrm{H}$ & ARTECAM & Artemisia campestris & 0.0 & 0.1 & 0.0 & 0.0 & 0.0 & 33.3 & 1.1 \\
\hline $\mathrm{H}$ & VIOLADU & Viola adunca & 0.1 & 0.0 & 0.0 & 0.0 & 0.0 & 33.3 & 1.1 \\
\hline G & AGROSCA & Agrostis scabra & 0.0 & 0.0 & 0.1 & 0.0 & 0.0 & 33.3 & 1.1 \\
\hline $\mathrm{L}$ & CLADDEF & Cladonia deformis & 0.0 & 0.1 & 0.0 & 0.0 & 0.0 & 33.3 & 1.1 \\
\hline $\mathrm{L}$ & CLADCOR & Cladonia cornuta & 0.1 & 0.0 & 0.0 & 0.0 & 0.0 & 33.3 & 1.1 \\
\hline $\mathrm{L}$ & CLADCAR & Cladonia cariosa & 0.1 & 0.0 & 0.0 & 0.0 & 0.0 & 33.3 & 1.1 \\
\hline $\mathrm{L}$ & CLADBEL & Cladonia bellidiflora & 0.0 & 0.1 & 0.0 & 0.0 & 0.0 & 33.3 & 1.1 \\
\hline S2 & PRUNPEN & Prunus pensylvanica & 0.0 & 0.1 & 0.0 & 0.0 & 0.0 & 33.3 & 1.1 \\
\hline S3 & AMELALN & Amelanchier alnifolia & 0.1 & 0.0 & 0.0 & 0.0 & 0.0 & 33.3 & 1.1 \\
\hline $\mathrm{H}$ & EQUIHYE & Equisetum hyemale & 0.1 & 0.0 & 0.0 & 0.0 & 0.0 & 33.3 & 1.1 \\
\hline $\mathrm{H}$ & ASTELAE & Aster laevis & 0.1 & 0.0 & 0.0 & 0.0 & 0.0 & 33.3 & 1.1 \\
\hline G & ELYMINN & Leymus innovatus & 0.1 & 0.0 & 0.0 & 0.0 & 0.0 & 33.3 & 1.1 \\
\hline $\mathrm{L}$ & PELTCAN & Peltigera canina & 0.1 & 0.0 & 0.0 & 0.0 & 0.0 & 33.3 & 1.1 \\
\hline $\mathrm{H}$ & GALIBOR & Galium boreale & 0.1 & 0.0 & 0.0 & 0.0 & 0.0 & 33.3 & 1.1 \\
\hline
\end{tabular}

Allen and Johnson (no date.) and Meijer (2002c) described a Pinus banksiana / Cladina mitis type from the Marguerite River Wildland Park. This was considered to be a common plant community in northeastern Alberta. Stands occur on sandy area with rapidly drained soils and xeric moisture conditions. The shrub and herb layers were sparse or limited to a few denser patches of Vaccinium myrtilloides and scattered Picea glauca. Meijer (2002c) found this type to be most common on exposed crests with convex surface profiles. Arctostaphylos uva-ursi and Hudsonia tomentosa were both present in small amounts. Raup and Argus (1982) described a Pinus banksiana / lichen type that occurred on stabilised dunes and 
sandy till plains south of Lake Athabasca. In mature stands lichen mats formed that consisted of Cladina arbuscula, C. mitis, C. rangiferina, C. stellaris, Cladonia amaurocraea and C. gracilis. Polytrichum juniperinum and $P$. piliferum also formed pure mats or were intermixed with lichens. Common understorey vascular plants species included Hudsonia tomentosa, Empetrum nigrum, Arctostaphylos uvaursi, and Vaccinium myrtilloides. Hermesh (1972) provided a brief description of a Pinus banksiana / Cladina spp. type that occurred in sheltered areas of the Lake Athabasca dunes. This community had scattered Pinus banksiana cover, with a dense mat of Cladina rangiferina and $C$. mitis mixed with patches of Arctostaphylos uva-ursi. Other species included Betula papyrifera, Vaccinium myrtilloides and Cetraria spp. Mackenzie River Basin Committee (1981) identified a Pinus banksiana - Arctostaphylos uva-ursi community at Lake Athabasca. This community was very similar to the other types described above.

Beckingham and Archibald (1996) identified a Pinus banksiana / Arctostaphylos uva-ursi / Cladina mitis plant community type (a.1.1). This boreal mixedwood type was very similar to the current type with exception that was has a higher content of Arctostaphylos uva-ursi $(\geq 20 \%)$ as opposed to trace amounts in the current classification. Otherwise cover of other the dominant and diagnostic species were similar.

NatureServe (2004) lists a Pinus banksiana / Lichens Woodland (CEGL002522) that was ranked as GNR. This community was a Manitoba CDC classification (Greenall 1996) but according to NatureServe (2004) it needs "rangewide review". It was part of the Pinus (banksiana, resinosa) Woodland Alliance but no details were provided regarding floristics. Similarity ratings for related plant community types are provided in Table 12 .

Table 12. Correlation table of plant community types with similarity ratings for the Pinus banksiana / Cladina mitis community type.

\begin{tabular}{|l|c|l||}
\hline \multicolumn{1}{|c|}{ Similar Types } & $\begin{array}{c}\text { Similarity } \\
\text { Rating }\end{array}$ & \multicolumn{1}{|c||}{ Comments } \\
\hline $\begin{array}{l}\text { Pinus banksiana / Arctostaphylos } \\
\text { uva-ursi / Cladina mitis CT (Nelson } \\
\text { et al. } \text { 1989). }\end{array}$ & 2 & $\begin{array}{l}\text { Related type but it has much higher cover of } \\
\text { Arctostaphylos uva-ursi and much lower cover of } \\
\text { Cladina mitis. }\end{array}$ \\
\hline $\begin{array}{l}\text { Pinus banksiana / Vaccinium } \\
\text { myrtilloides / Cladina mitis CT } \\
\text { (Allen } \text { et al. 2003) }\end{array}$ & 3 & $\begin{array}{l}\text { No details were available but it appears to have higher } \\
\text { cover of } \text { Vaccinium myrtilloides. }\end{array}$ \\
\hline $\begin{array}{l}\text { Pinus banksiana / Arctostaphylos } \\
\text { uva-ursi CT (Allen } \text { et al. 2002) }\end{array}$ & $2(1)$ & $\begin{array}{l}\text { A related type but no details were available for further } \\
\text { comparison. }\end{array}$ \\
\hline $\begin{array}{l}\text { Pinus banksiana / Cladina mitis CT } \\
\text { (Allen and Johnson no date, Meijer } \\
\text { 2002c) }\end{array}$ & 1 & $\begin{array}{l}\text { Based on the plot data this would appear to be the same } \\
\text { community type. }\end{array}$ \\
\hline $\begin{array}{l}\text { Pinus banksiana / Heath CT } \\
\text { (Mackenzie River Basin Comm. } \\
\text { 1981) }\end{array}$ & $2(1)$ & $\begin{array}{l}\text { Very similar type occurring on similar sites. Appears to } \\
\text { have higher cover of } \text { Arctostaphylos uva-ursi. }\end{array}$ \\
\hline $\begin{array}{l}\text { Pinus banksiana / lichen CT (Raup } \\
\text { and Argus 1982) }\end{array}$ & $1(2)$ & $\begin{array}{l}\text { Very similar or possibly identical type. Plants species } \\
\text { list for the type was large and may include other } \\
\text { community types based on the scale used for description. }\end{array}$ \\
\hline $\begin{array}{l}\text { Pinus banksiana / Cladina } \text { spp. CT } \\
\text { Hermesh (1972) }\end{array}$ & 1 & $\begin{array}{l}\text { Quite similar type with high cover of } \text { Cladina } \text { spp. and } \\
\text { scattered Pinus banksiana. }\end{array}$ \\
\hline $\begin{array}{l}\text { Pinus banksiana / Arctostaphylos } \\
\text { uva-ursi / Cladina mitis CT (a.1.1). } \\
\text { (Beckingham and Archibald 1996) }\end{array}$ & $2(1)$ & $\begin{array}{l}\text { Very similar type occurring on similar sites. Main } \\
\text { difference was the higher cover of } \text { Arctostaphylos uva- } \\
\text { ursi in this type. }\end{array}$ \\
\hline $\begin{array}{l}\text { Pinus banksiana / Lichens Woodland } \\
\text { (CEGL002522) (NatureServe 2004) }\end{array}$ & 2 & $\begin{array}{l}\text { Appears to be a very closely related type but more } \\
\text { details were required regarding the floristics. }\end{array}$ \\
\hline
\end{tabular}




\subsubsection{Picea glauca - Picea mariana / Rosa acicularis / Cornus canadensis Forest \\ White Spruce - Black Spruce / Prickly Rose / Bunchberry Forest}

White spruce stands were not common within either study area and only one plot was completed in the Holmes Crossing Sandhills Ecological Reserve (Table 13). This was a small stand located on a small northeast-facing slope adjacent to a stream and beaver pond. Soils were well drained with mesic moisture levels and a mesotrophic nutrient regime. The surface substrate cover consisted mostly of organic matter (94\%) and decaying wood (4\%). The overstorey cover consisted of Picea glauca (40\%) and Picea mariana (20\%). The shrub layer was open and included Rosa acicularis (3\%), Cornus canadensis (3\%), Vaccinium myrtilloides (2\%), and trace amounts of Betula papyrifera, Rubus idaeus, Prunus pensylvanica, and Viburnum edule. The herbaceous layer was quite diverse but all species occurred at $1 \%$ or less cover. These included Aralia nudicaulis, Fragaria virginiana, Rubus pubescens, Equisetum scirpoides Aster laevis Pyrola chlorantha, Geocaulon lividum, Maianthemum canadense, Orthilia secunda, Linnaea borealis, Pyrola asarifolia, Equisetum pratense, Equisetum arvense, Aster conspicuus, Leymus innovatus, and Viola renifolia. Moss cover consisted of Brachythecium salebrosum (10\%), Ptilium crista-castrensis (2\%), Hylocomium splendens (1\%), and trace Pleurozium schreberi.

Class: Forest

Subclass: Evergreen Forest

Group: Temperate or subpolar needle-leaved evergreen forest

Subgroup: Natural/Semi-natural temperate or subpolar needle-leaved evergreen forest

Formation: Conical-crowned temperate or subpolar needle-leaved evergreen forest

Alliance: Picea glauca- Picea mariana Forest Alliance (Proposed)

Association: Picea glauca - Picea mariana / Rosa acicularis / Cornus canadensis Forest

Unique Identifier: $\mathrm{n} / \mathrm{a}$

Classification Confidence Level: 3 (Weak) Only one plot completed in a small stand and this community type was not well documented in the literature. Geographical range was unknown.

Dominant Species: Picea glauca, Picea mariana, Cornus canadensis, Rosa acicularis

Co-Dominant Species: Vaccinium myrtilloides, Aralia nudicaulis, Fragaria virginiana, Rubus pubescens, Brachythecium salebrosum, Ptilium crista-castrensis, Hylocomium splendens

Diagnostic Species: Picea glauca, Picea mariana, Rosa acicularis, Cornus canadensis, Brachythecium salebrosum

\section{Literature Review:}

Picea mariana was common in this stand and in this classification it was placed under a new alliance named the Picea glauca - Picea mariana Forest Alliance. No Abies balsamea was recorded in this community but it may be expected to be part of more climax stands and therefore may be part of the Picea glauca - Abies balsamea Forest Alliance.

Timoney and Robinson (1998) noted a Picea glauca / Cornus stolonifera / Viburnum edule / Equisetum pratense / feather moss type in the Ft. Assiniboine Sandhills Wildland Park. This was an old growth riparian type.

Allen and Johnson (no date.) described a Picea glauca / Viburnum edule - Rosa acicularis community type from the Richardson River Dunes Wildland Park. This mature forest had an understorey dominated by Viburnum edule and Rosa acicularis, and feather moss. Another type was described as a Picea glauca / Viburnum edule / Hylocomium splendens - Pleurozium schreberi community that was found along an old river channel. It had relatively high of Abies balsamea in understorey. 
Table 13. Summary of plot data and descriptive statistics for the Picea glauca - Picea mariana / Rosa acicularis / Cornus canadensis community type $(\mathrm{n}=1)$.

\begin{tabular}{|c|c|c|c|c|c|c|c|}
\hline \multirow[b]{2}{*}{ Strata } & \multirow[b]{2}{*}{ Code } & \multirow[b]{2}{*}{ Species } & \multirow{2}{*}{$\begin{array}{l}\text { Plot } \\
\text { P19 } \\
\end{array}$} & \multirow[b]{2}{*}{ Strata } & \multirow[b]{2}{*}{ Code } & \multirow[b]{2}{*}{ Species } & \multirow{2}{*}{$\begin{array}{l}\text { Plot } \\
\text { P19 }\end{array}$} \\
\hline & & & & & & & \\
\hline $\mathrm{Tl}$ & PICEGLA & Picea glauca & 40.0 & $\mathrm{H}$ & PETASAG & $\begin{array}{l}\text { Petasites frigidus var } \\
\text { sagittatus }\end{array}$ & 0.1 \\
\hline $\mathrm{T} 1$ & PICEMAR & Picea mariana & 20.0 & $\mathrm{H}$ & LATHOCH & Lathyrus ochroleucus & 0.1 \\
\hline M & BRACSAL & $\begin{array}{l}\text { Brachythecium } \\
\text { salebrosum }\end{array}$ & 10.0 & $\mathrm{H}$ & GEOCLIV & Geocaulon lividum & 0.1 \\
\hline $\mathrm{T} 2$ & PICEMAR & Picea mariana & 5.0 & $\mathrm{H}$ & MAIACAN & $\begin{array}{l}\text { Maianthemum } \\
\text { canadense }\end{array}$ & 0.1 \\
\hline S3 & RUBUPUB & Rubus pubescens & 3.0 & $\mathrm{H}$ & ORTHSEC & Orthilia secunda & 0.1 \\
\hline S3 & CORNCAN & Cornus canadensis & 3.0 & $\mathrm{H}$ & GALIBOR & Galium boreale & 0.1 \\
\hline S3 & ROSAACI & Rosa acicularis & 3.0 & S3 & LINNBOR & Linnaea borealis & 0.1 \\
\hline M & PTILCRI & Ptilium crista-castrensis & 2.0 & $\mathrm{H}$ & PYROASA & Pyrola asarifolia & 0.1 \\
\hline S3 & VACCMYR & Vaccinium myrtilloides & 2.0 & $\mathrm{H}$ & EQUIPRA & Equisetum pratense & 0.1 \\
\hline $\mathrm{H}$ & ARALNUD & Aralia nudicaulis & 1.0 & $\mathrm{H}$ & CAMPROT & Campanula rotundifolia & 0.1 \\
\hline $\mathrm{H}$ & FRAGVIR & Fragaria virginiana & 1.0 & S3 & RUBUIDA & Rubus idaeus & 0.1 \\
\hline M & HYLOSPL & Hylocomium splendens & 1.0 & S3 & VACCVIT & Vaccinium vitis-idaea & 0.1 \\
\hline $\mathrm{E}$ & EPIPHYT & Epiphyte spp. & 0.1 & $\mathrm{H}$ & ASTECON & Aster conspicuus & 0.1 \\
\hline $\mathrm{H}$ & LYCOANN & Lycopodium annotinum & 0.1 & S3 & VIBUEDU & Viburnum edule & 0.1 \\
\hline $\mathrm{H}$ & EQUISCI & Equisetum scirpoides & 0.1 & G & ELYMINN & Leymus innovatus & 0.1 \\
\hline $\mathrm{H}$ & ASTELAE & Aster laevis & 0.1 & S3 & PRUNPEN & Prunus pensylvanica & 0.1 \\
\hline M & PLEUSCH & Pleurozium schreberi & 0.1 & $\mathrm{H}$ & EQUIARV & Equisetum arvense & 0.1 \\
\hline S3 & BETUPAP & Betula papyrifera & 0.1 & $\mathrm{H}$ & VIOLREN & Viola renifolia & 0.1 \\
\hline $\mathrm{H}$ & PYROCHL & Pyrola chlorantha & 0.1 & & & & \\
\hline
\end{tabular}

Beckingham and Archibald (1996) described a Picea glauca / Viburnum edule type (d3.3) that was found in the boreal mixedwood. This community was very similar to the current type although percent cover of dominants and diagnostic species varied. The main differences in composition were the presence of Populus tremuloides and Populus balsamifera in the overstorey and Mertensia paniculata in the herb layer of this type. Viburnum edule was recorded at trace cover in the Holmes Crossing plot. These were considered relatively moderate to minor differences and may be more a function of small stand size and sample size. Another related type identified by Beckingham and Archibald (1996) was the Picea glauca / Feather moss community (d3.5). This type shares similar site characteristics and species composition. All species recorded in the Holmes Crossing type were included as indicator species for this type with the exception of Populus balsamifera. Also Picea mariana was a co-dominant in the overstorey at Holmes Crossing but was not included as an important species in this type.

No similar Picea glauca Associations were listed by NatureServe (2004) although they do described a Picea mariana / Pleurozium schreberi Forest (CEGL002447) that has some similar characteristics. This type occurred in Quebec, Ontario, Manitoba (Greenall 1996, Sims et al. 1989) and adjacent areas in the midwest United States. It was found on level to gently sloping ground where the soils were moderately well-drained, coarse loams, sands, and silts. The closed canopy was dominated by Picea mariana with some cover of Abies balsamea, Betula papyrifera, Picea glauca, Pinus banksiana, and Populus tremuloides. The shrub layer was thin consisting of Corylus cornuta, Gaultheria procumbens, Ledum groenlandicum, Rosa acicularis, Vaccinium angustifolium, and Vaccinium myrtilloides. The herb layer was sparse but may include Eurybia macrophylla (= Aster macrophyllus), Cornus canadensis, Equisetum arvense, and Maianthemum canadense. Feather moss cover was high and was dominated by Pleurozium 
schreberi. The main difference with the current classification was the lack of Picea glauca in this type and the higher cover of mosses. However, the plot completed in North Buck Lake study area was more well developed moss layer. Similarity ratings for related plant community types are provided in Table 14 .

Table 14. Correlation table of plant community types with similarity ratings for Picea glauca - Picea mariana / Rosa acicularis / Cornus canadensis type.

\begin{tabular}{||l|c|l||}
\hline \multicolumn{1}{|c|}{ Similar Types } & $\begin{array}{c}\text { Similarity } \\
\text { Rating }\end{array}$ & \multicolumn{1}{c|}{ Comments } \\
\hline $\begin{array}{l}\text { Picea glauca / Cornus stolonifera / } \\
\text { Viburnum edule / Equisetum pratense } \\
\text { / feather moss (Timoney and } \\
\text { Robinson 1998) }\end{array}$ & 3 & $\begin{array}{l}\text { This may be a related type although no further details } \\
\text { were available for comparing the two types. }\end{array}$ \\
\hline $\begin{array}{l}\text { Picea glauca / Viburnum edule- } \\
\text { Rosa acicularis CT (Allen and } \\
\text { Johnson no date) }\end{array}$ & 2 & $\begin{array}{l}\text { Likely a similar type however more details were required } \\
\text { about its species composition and site characteristics. }\end{array}$ \\
\hline $\begin{array}{l}\text { Picea glauca /Viburnum edule / } \\
\text { Hylocomium splendens - Pleurozium } \\
\text { schreberi CT (Allen and Johnson no } \\
\text { date) }\end{array}$ & 3 & $\begin{array}{l}\text { Possibly a similar type however more details were } \\
\text { required about its species composition and site } \\
\text { characteristics. }\end{array}$ \\
\hline $\begin{array}{l}\text { Picea glauca / Viburnum edule CT } \\
\text { (d3.3) (Beckingham and Archibald } \\
\text { 1996) }\end{array}$ & $1(2)$ & $\begin{array}{l}\text { This type occupies a similar ecological niche and has } \\
\text { very similar floristics. Differences in composition were } \\
\text { likely a function of the small stand size and lack of plots } \\
\text { completed on the current study. Picea mariana } \text { was } \\
\text { present at less than 2\% cover in this CT. }\end{array}$ \\
\hline $\begin{array}{l}\text { Picea glauca / Feather moss CT } \\
\text { (d3.5) (Beckingham and Archibald } \\
\text { 1996) }\end{array}$ & 2 & $\begin{array}{l}\text { A related type that was found in similar sites and has } \\
\text { similar floristics. Again differences in composition may } \\
\text { be function of the small stand size and sample size. }\end{array}$ \\
\hline $\begin{array}{l}\text { Picea mariana / Pleurozium } \\
\text { schreberi Forest (CEGL002447) } \\
\text { (NatureServe 2004) }\end{array}$ & 3 & $\begin{array}{l}\text { Some similarity in species composition but there were } \\
\text { important differences and it included a number of eastern } \\
\text { species. Range may not extend into Alberta. }\end{array}$ \\
\hline
\end{tabular}




\subsubsection{Picea glauca - Picea mariana/Ledum groenlandicum /Equisetum arvense Forest White Spruce - Black Spruce / Labrador Tea / Common Horsetail Forest}

This community type was not common and only one stand was encountered. This site was in the North Buck Lake study area and was on a nearly level receiving site located at the base of a small knoll. Soils were moderately well drained with mesic moisture levels and a mesotrophic nutrient regime. The overstorey was closed and was dominated by Picea glauca (20\%) and Picea mariana (25\%) with trace amounts of Populus tremuloides and Populus balsamifera (Table 15). Dominant cover in the shrub layer consisted of Alnus incana spp. tenuifolia (5\%), Ledum groenlandicum (3\%), and Vaccinium myrtilloides (1\%). The low shrub layer included trace amounts of Abies balsamea, Linnaea borealis, Vaccinium vitisidaea, Lonicera involucrata, Ribes triste, Picea glauca, and Populus balsamifera. Equisetum arvense was the dominant herb at $60 \%$ cover. A variety of other herbs were present at trace to $2 \%$ cover values including Petasites frigidus var sagittatus, Petasites frigidus var palmatus, Smilacina trifolia, Viola renifolia, Rubus arcticus, Scutellaria galericulata, Rubus pubescens, and Mitella nuda. The moss layer was diverse and the dominant cover consisted of Pleurozium schreberi (20\%), Sphagnum magellanicum (5\%), Aulacomnium palustre (5\%), Hylocomium splendens (4\%), Brachythecium salebrosum (2\%), and Drepanocladus aduncus (2\%), and trace amounts of Ptilium crista-castrensis.

Class: Forest

Subclass: Evergreen Forest

Group: Temperate or subpolar needle-leaved evergreen forest

Subgroup: Natural/Semi-natural temperate or subpolar needle-leaved evergreen forest

Formation: Temporarily flooded temperate or subpolar needle-leaved evergreen forest

Alliance: Picea glauca Temporarily Flooded Forest Alliance

Association: Picea glauca - Picea mariana / Ledum groenlandicum / Equisetum arvense Forest

Unique Identifier: $\mathrm{n} / \mathrm{a}$

Classification Confidence Level: 2 (Moderate) Only one plot completed but there was a relatively good correlation to other documented types in the literature. It was likely common throughout the boreal region.

Dominant Species: Picea glauca, Picea mariana, Equisetum arvense, Pleurozium schreberi Co-Dominant Species: Alnus incana spp tenuifolia, Ledum groenlandicum, Aulacomnium palustre, Hylocomium splendens, Sphagnum magellanicum

Diagnostic Species: Picea glauca, Picea mariana, Alnus incana spp tenuifolia, Equisetum arvense, Petasites frigidus var sagittatus, Petasites frigidus var palmatus, Rubus arcticus, Pleurozium schreberi, Aulacomnium palustre, Sphagnum magellanicum

\section{Literature Review:}

Allen (2004) lists a Picea glauca / Alnus tenuifolia - Betula neoalaskana / Equisetum pratense / Hylocomium splendens boreal forest type (CEAB000040). It was found in riparian zones of major river valleys in northwestern Canada. This community was mostly restricted to silt-bearing rivers with extensive silt terraces where flooding was common. Soils were imperfectly drained silty alluvium Cumulic Regosols with hygric moisture levels. It tends to be old-growth forests with high biodiversity. Canopy openings were dominated by Alnus tenuifolia, Betula neoalaskana, Cornus stolonifera and other shrubs. The moss layer was dense. Equisetum spp. cover was not noted as being high.

Allen and Johnson (no date.) described a Picea glauca / Equisetum arvense community type from the Richardson River Dunes Wildland Park. This was a mature forest along the Athabasca River with an understorey dominated by Rosa acicularis, Cornus stolonifera and Viburnum edule. 
Table 15. Summary of plot data and descriptive statistics for the Picea glauca - Picea mariana / Ledum groenlandicum / Equisetum arvense community type $(\mathrm{n}=1)$.

\begin{tabular}{|c|c|c|c|}
\hline & & & Plot \\
\hline Strata & Code & Species & P37 \\
\hline $\mathrm{H}$ & EQUIARV & Equisetum arvense & 60.0 \\
\hline $\mathrm{T} 2$ & PICEMAR & Picea mariana & 25.0 \\
\hline $\mathrm{T} 1$ & PICEGLA & Picea glauca & 20.0 \\
\hline M & PLEUSCH & Pleurozium schreberi & 20.0 \\
\hline M & SPHAMAG & $\begin{array}{l}\text { Sphagnum } \\
\text { magellanicum }\end{array}$ & 5.0 \\
\hline M & AULAPAL & Aulacomnium palustre & 5.0 \\
\hline S1 & ALNUTEN & $\begin{array}{l}\text { Alnus incana spp } \\
\text { tenuifolia }\end{array}$ & 5.0 \\
\hline M & HYLOSPL & Hylocomium splendens & 4.0 \\
\hline S3 & LEDUGRO & Ledum groenlandicum & 3.0 \\
\hline M & BRACSAL & $\begin{array}{l}\text { Brachythecium } \\
\text { salebrosum }\end{array}$ & 2.0 \\
\hline $\mathrm{H}$ & PETASAG & $\begin{array}{l}\text { Petasites frigidus var } \\
\text { sagittatus }\end{array}$ & 2.0 \\
\hline M & DREPADU & $\begin{array}{l}\text { Drepanocladus } \\
\text { aduncus }\end{array}$ & 2.0 \\
\hline G & CAREDIS & Carex disperma & 1.0 \\
\hline $\mathrm{H}$ & SMILTRI & Smilacina trifolia & 1.0 \\
\hline $\mathrm{H}$ & VIOLREN & Viola renifolia & 1.0 \\
\hline S3 & VACCMYR & Vaccinium myrtilloides & 1.0 \\
\hline G & CALACAN & $\begin{array}{l}\text { Calamagrostis } \\
\text { canadensis }\end{array}$ & 1.0 \\
\hline S3 & ABIEBAL & Abies balsamea & 0.1 \\
\hline
\end{tabular}

\begin{tabular}{|c|c|c|c|}
\hline & & & Plot \\
\hline Strata & Code & Species & P37 \\
\hline $\mathrm{H}$ & SCUTGAL & Scutellaria galericulata & 0.1 \\
\hline S3 & RUBUPUB & Rubus pubescens & 0.1 \\
\hline $\mathrm{T} 2$ & POPUTRE & Populus tremuloides & 0.1 \\
\hline $\mathrm{H}$ & PETAPAL & $\begin{array}{l}\text { Petasites frigidus var } \\
\text { palmatus }\end{array}$ & 0.1 \\
\hline $\mathrm{H}$ & MITENUD & Mitella nuda & 0.1 \\
\hline M & PTILCRI & Ptilium crista-castrensis & 0.1 \\
\hline $\mathrm{T} 2$ & POPUBAL & Populus balsamifera & 0.1 \\
\hline S3 & LINNBOR & Linnaea borealis & 0.1 \\
\hline S3 & VACCVIT & Vaccinium vitis-idaea & 0.1 \\
\hline S3 & LONIINV & Lonicera involucrata & 0.1 \\
\hline S3 & RIBETRI & Ribes triste & 0.1 \\
\hline S3 & PICEGLA & Picea glauca & 0.1 \\
\hline $\mathrm{H}$ & RUBUACA & Rubus arcticus & 0.1 \\
\hline $\mathrm{H}$ & MELALIN & Medicago lupulina & 0.1 \\
\hline S3 & POPUBAL & Populus balsamifera & 0.1 \\
\hline $\mathrm{H}$ & TRIEBOR & Trientalis borealis & 0.1 \\
\hline $\mathrm{H}$ & GEOCLIV & Geocaulon lividum & 0.1 \\
\hline
\end{tabular}

Beckingham and Archibald (1996) described a Picea glauca - Picea mariana - Ledum groenlandicum / Equisetum spp. type (h1.1) that occurred in the boreal mixedwood. This community was similar to the current type but additional species included Salix spp., Rosa acicularis, Betula papyrifera, Equisetum pratense, and Equisetum scirpoides. It also had more Ledum groenlandicum cover.

NatureServe (2004) lists a Picea mariana / Salix myrtillifolia / Aulacomnium palustre Woodland (CEGL002730) with a G4 ranking. This community will be part of the Picea mariana / Sphagnum spp. Forest Alliance (A.4053). It was a wet woodland community found in northern British Columbia's Boreal White and Black Spruce biogeoclimatic zone (Allen et al. 2004, Baldwin et al. 2004). It occurred as small patches on toe slopes or depressions. Soils were usually organic or fine-textured with organic or fluvial origins. Moisture levels were hygric to subhydric and soils were mesotrophic to permesotrophic. Stands heights were low and often Picea mariana forms an open canopy in the tall shrub layer. Low shrubs include high percent cover of Ledum groenlandicum and Salix myrtillifolia. The herb layer was sparse and consisted of Vaccinium vitis-idaea, Equisetum scirpoides, Equisetum arvense and sometimes Arctostaphylos rubra (= Arctostaphylos alpina var. rubra) and Cornus canadensis. The moss layer was dense and included Aulacomnium palustre and Hylocomium splendens, and commonly Tomentypnum nitens, Pleurozium schreberi, and Sphagnum species. Lichen cover was low but may include Cladina and Peltigera species. 
NatureServe (2004) lists a Picea glauca - Abies balsamea / Pleurozium schreberi Forest

(CEGL002509) ranked GNR. This type was found in northern Ontario (Sims et al. 1989), Manitoba (Greenall 1996), and possibly parts of the boreal forest. Stands were dominated by Picea glauca and Abies balsamea. The shrub and herb layer was sparse while the moss cover was high and was mainly Pleurozium schreberi. This type does not appear to have high cover of Equisetum spp. Similarity ratings for related plant community types are provided in Table 16.

Table 16. Correlation table of plant community types with similarity ratings for the Picea mariana - Picea glauca / Ledum groenlandicum / Equisetum arvense type.

\begin{tabular}{||l|c|l||}
\hline \multicolumn{1}{|c|}{ Similar Types } & $\begin{array}{c}\text { Similarity } \\
\text { Rating }\end{array}$ & \multicolumn{1}{|c||}{ Comments } \\
\hline \hline $\begin{array}{l}\text { Picea glauca / Alnus tenuifolia - } \\
\text { Betula neoalaskana / Equisetum } \\
\text { pratense / Hylocomium splendens CT } \\
\text { (CEAB000040) Allen (2004) }\end{array}$ & 3 & $\begin{array}{l}\text { Similar type but there are important differences in } \\
\text { species composition and habitat conditions }\end{array}$ \\
\hline $\begin{array}{l}\text { Picea glauca / Equisetum arvense CT } \\
\text { (Allen and Johnson no date) }\end{array}$ & 2 & Possibly a similar type but more details are required. \\
\hline $\begin{array}{l}\text { Picea glauca - Picea mariana - } \\
\text { Ledum groenlandicum / Equisetum } \\
\text { spp. CT (h1.1) (Beckingham and } \\
\text { Archibald 1996) }\end{array}$ & $1(2)$ & $\begin{array}{l}\text { Similar type but some differences in plant community } \\
\text { composition. This may be attributed to the small stand } \\
\text { size and influence of adjacent communities at the North } \\
\text { Buck Lake site. }\end{array}$ \\
\hline $\begin{array}{l}\text { Picea mariana / Salix myrtillifolia / } \\
\text { Aulacomnium palustre Woodland } \\
\text { (CEGL002730) (NatureServe 2004) }\end{array}$ & $3(2)$ & $\begin{array}{l}\text { This type has a similar species composition. Current } \\
\text { type did not have any Salix myrtillifolia cover and Picea } \\
\text { glauca was not a dominant species. }\end{array}$ \\
\hline $\begin{array}{l}\text { Picea glauca } \text { - Abies balsamea/ } \\
\text { Pleurozium schreberi Forest } \\
\text { (CEGL002509) (NatureServe 2004) }\end{array}$ & 3 & $\begin{array}{l}\text { Few details available but this was possibly a similar type. } \\
\text { However, Picea mariana } \text { and Equisetum spp. are not } \\
\text { dominant species. }\end{array}$ \\
\hline
\end{tabular}

\subsubsection{Picea mariana - Larix laricina /Ledum groenlandicum / Tomentypnum nitens Forest Black Spruce - Tamarack / Labrador-tea / Golden Moss Forest}

This community does not appear to be common and only one plot was completed in the Holmes Crossing Sandhills Ecological Reserve (Table 17). This stand occurred on a level site in a lowland depression. The micro-topography was hummocky with frequent micro-mounding of under $0.3 \mathrm{~m}$. The water table at this site was less than $15 \mathrm{~cm}$ from the ground surface thus maintaining a relatively constant subhygric moisture level. The Organic soils were imperfectly drained and had a mesotrophic nutrient regime. This was a dense stand with $70 \%$ cover of Picea mariana in the tall shrub layer. A few patches of mature Larix laricina formed an open canopy in the overstorey. The low shrub layer had less than $15 \%$ cover consisting primarily of Ledum groenlandicum and Salix myrtillifolia. Graminoid cover was less than 10\% consisting of Carex diandra, Carex disperma, Carex chordorrhiza, and Calamagrostis stricta. Moss cover was dense and included Tomentypnum nitens (80\%), Hylocomium splendens (5\%), Pleurozium schreberi $(4 \%)$, and Aulacomnium palustre (2\%). 
Class: Forest

Subclass: Evergreen Forest

Group: Temperate or subpolar needle-leaved evergreen forest

Subgroup: Natural/Semi-natural temperate or subpolar needle-leaved evergreen forest

Formation: Saturated temperate or subpolar needle-leaved evergreen forest

Alliance: Picea mariana Saturated Forest

Association: Picea mariana - Larix laricina / Ledum groenlandicum / Tomentypnum nitens Forest

Unique Identifier: $n / a$

Classification Confidence Level: 3 (Weak) The one stand sampled was very dense and may not have been representative of the type. This type was not well represented in the literature and the geographic range was not known.

Dominant Species: Picea mariana, Ledum groenlandicum, Tomentypnum nitens

Co-Dominant Species: Larix laricina, Salix myrtillifolia, Carex spp, Carex disperma, Hylocomium splendens, Pleurozium schreberi, Aulacomnium palustre

Diagnostic Species: Picea mariana, Larix laricina, Ledum groenlandicum, Tomentypnum nitens

Table 17. Summary of plot data and descriptive statistics for the Picea mariana - Larix laricina / Ledum groenlandicum / Tomentypnum nitens community type $(\mathrm{n}=1)$.

\begin{tabular}{|cllc||}
\hline & & & \multicolumn{1}{c|}{ Plot } \\
\cline { 4 - 4 } Strata & \multicolumn{1}{c}{ Code } & \multicolumn{1}{c|}{ Species } & $\mathbf{3 0}$ \\
\hline M & TOMENIT & Tomentypnum nitens & 80.0 \\
S1 & PICEMAR & Picea mariana & 70.0 \\
T1 & LARILAR & Larix laricina & 8.0 \\
S3 & LEDUGRO & Ledum groenlandicum & 8.0 \\
M & HYLOSPL & Hylocomium splendens & 5.0 \\
T2 & PICEMAR & Picea mariana & 5.0 \\
M & PLEUSCH & Pleurozium schreberi & 4.0 \\
G & CAREDIA & Carex diandra & 4.0 \\
S3 & SALIMYR & Salix myrtillifolia & 3.0 \\
G & CAREDIS & Carex disperma & 2.0 \\
M & AULAPAL & Aulacomnium palustre & 2.0 \\
L & PELTIGE & Peltigera sp. & 1.0 \\
M & SPHAFUS & Sphagnum fuscum & 0.1 \\
G & CARECHO & Carex chordorrhiza & 0.1 \\
H & SMILTRI & Smilacina trifolia & 0.1 \\
H & RUBUACA & Rubus arcticus & 0.1 \\
G & CAREINT & Carex interior & 0.1 \\
H & PETASAG & Petasites frigidus var & 0.1 \\
& & sagittatus & \\
\hline
\end{tabular}

\begin{tabular}{|c|c|c|c|}
\hline & & & Plot \\
\hline Strata & Code & Species & 30 \\
\hline S3 & BETUPUM & Betula pumila & 0.1 \\
\hline $\mathrm{H}$ & POTEPAL & Potentilla palustris & 0.1 \\
\hline $\mathrm{H}$ & ORTHSEC & Orthilia secunda & 0.1 \\
\hline M & MOSSES\$\$ & Moss spp. & 0.1 \\
\hline M & DICRPOL & Dicranum polysetum & 0.1 \\
\hline M & PTILCRI & Ptilium crista-castrensis & 0.1 \\
\hline $\mathrm{L}$ & PELTAPH & Peltigera aphthosa & 0.1 \\
\hline $\mathrm{L}$ & CLADMIT & Cladina mitis & 0.1 \\
\hline G & CALASTR & Calamagrostis stricta & 0.1 \\
\hline S3 & VACCMYR & Vaccinium myrtilloides & 0.1 \\
\hline G & CAREVAG & Carex vaginata & 0.1 \\
\hline G & CAREPAP & Carex paupercula & 0.1 \\
\hline $\mathrm{H}$ & MENYTRI & Menyanthes trifoliata & 0.1 \\
\hline G & CALACAN & $\begin{array}{l}\text { Calamagrostis } \\
\text { canadensis }\end{array}$ & 0.1 \\
\hline $\mathrm{H}$ & FRAGVIR & Fragaria virginiana & 0.1 \\
\hline $\mathrm{T} 1$ & PINUBAN & Pinus banksiana & 0.1 \\
\hline S3 & VACCVIT & Vaccinium vitis-idaea & 0.1 \\
\hline $\mathrm{H}$ & EQUIARV & Equisetum arvense & 0.1 \\
\hline
\end{tabular}




\section{Literature Review:}

Timoney and Robinson (1998) noted a Larix / Menyanthes / Carex diandra / Tomentypnum community from fens in the Ft. Assiniboine Sandhills Wildland Park. Based on dominants listed for this type this would appear to be an identical or similar type.

Allen et al. (2002) reported that a Picea mariana / Salix myrtillifolia / Tomentypnum nitens Community Type found in La Butte Creek Wildland Provincial Park located north of Lake Athabasca. This type apparently occurred as small wetlands within old river channels. Other important species included Ledum groenlandicum, Sphagnum fuscum, and S. capillifolium.

Beckingham and Archibald (1996) described a Picea mariana - Larix laricina / Betula pumila / Carex spp. / Sphagnum spp. community type (j1.1) that occurred in the boreal mixedwood. This type has a very similar species composition but included significant cover of Betula pumila, has higher cover of Sphagnum spp. and less cover of Tomentypnum nitens. Similarity ratings for related plant community types are provided in Table 18.

Table 18. Correlation table of plant community types with similarity ratings for the Picea mariana - Larix laricina / Ledum groenlandicum / Tomentypnum nitens type.

\begin{tabular}{||l|c|l||}
\hline \multicolumn{1}{|c|}{ Similar Types } & $\begin{array}{c}\text { Similarity } \\
\text { Rating }\end{array}$ & \multicolumn{1}{c||}{ Comments } \\
\hline \hline $\begin{array}{l}\text { Larix / Menyanthes / Carex diandra / } \\
\text { Tomentypnum CT (fa44) (Timoney } \\
\text { and Robinson 1998) }\end{array}$ & $2(1)$ & $\begin{array}{l}\text { Very similar type based on the dominants used to } \\
\text { describe it. No details regarding floristics were available } \\
\text { for review. }\end{array}$ \\
\hline $\begin{array}{l}\text { Picea mariana / Salix myrtillifolia / } \\
\text { Tomentypnum nitens CT (Allen } \text { et al. } \\
\text { 2002) }\end{array}$ & 2 & $\begin{array}{l}\text { Limited information was available for this review but } \\
\text { this appears to be a related type. }\end{array}$ \\
\hline $\begin{array}{l}\text { Picea mariana - Larix laricina / } \\
\text { Betula pumila / Carex spp. / } \\
\text { Sphagnum spp. (Beckingham and } \\
\text { Archibald 1996) }\end{array}$ & $1(2)$ & $\begin{array}{l}\text { Very similar species composition although there was } \\
\text { considerable difference in percent of individual species. } \\
\text { Betula pumila was dominant in this CT, and Sphagnum } \\
\text { spp. cover was dominant over Tomentypnum nitens. }\end{array}$ \\
\hline
\end{tabular}




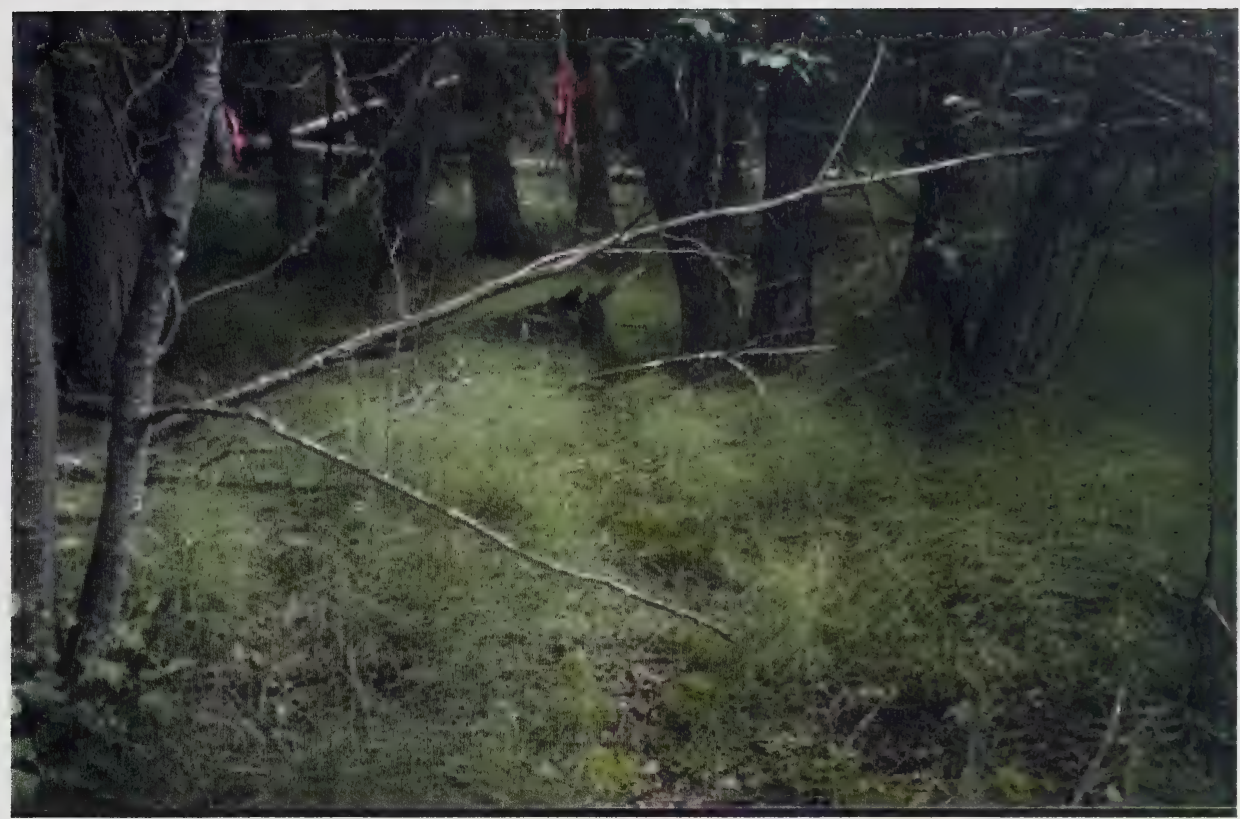

Plate 8. Picea glauca - Picea mariana /Ledum groenlandicum / Equisetum arvense Forest (P37).

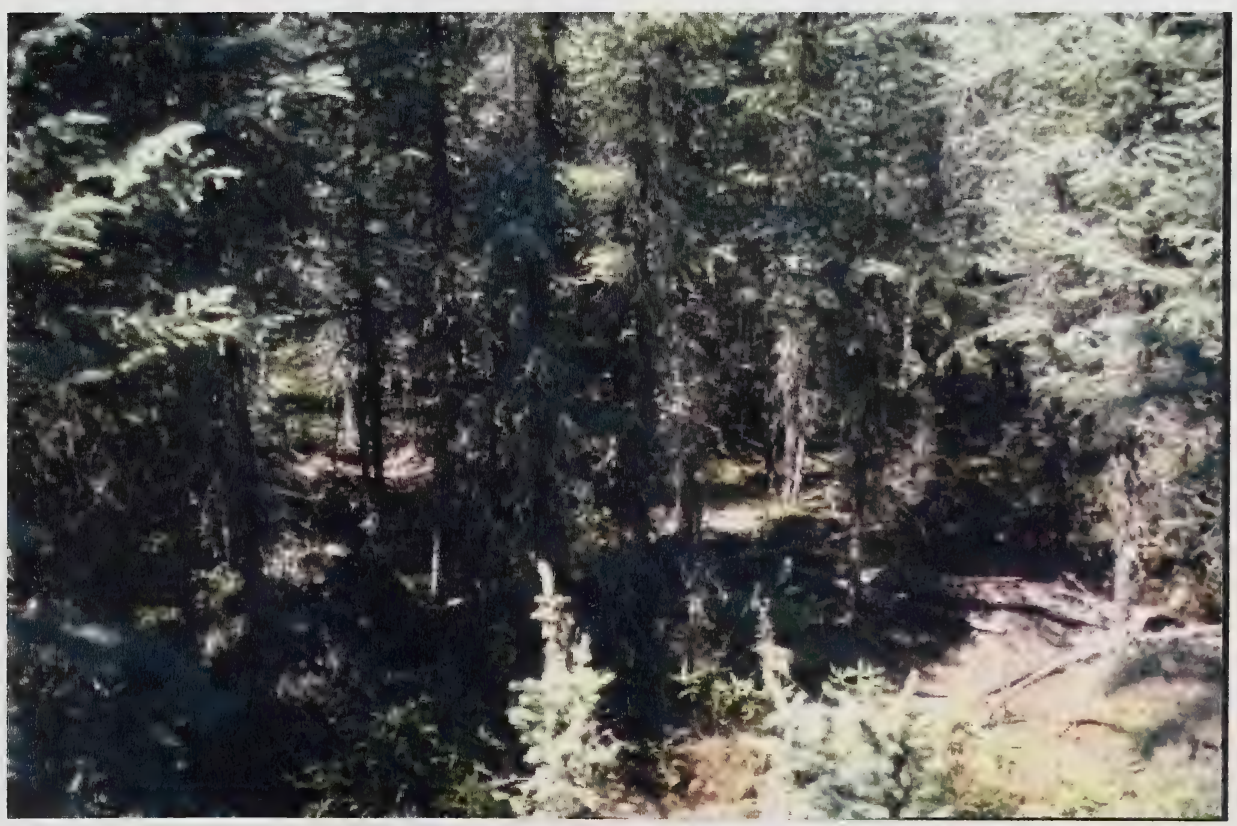

Plate 9. Picea mariana - Larix laricina / Ledum groenlandicum / Tomentypnum nitens Forest (P30). 


\subsubsection{Picea mariana - Larix laricina / Pleurozium schreberi Forest}

Black Spruce - Tamarack / Schreber's Feather Moss Forest

This type was relatively common in both Boreal Sand Dunes study areas and one plot was completed in both locations (Table 19). These sites occurred on level sites in depressional areas that were likely subjected to seasonal flooding and the water table remains close to the ground surface during the entire year. Soils were moderately well to imperfectly drained Organics. Soil moisture levels were typically mesic to subhygric with submesotrophic to mesotrophic nutrient regimes. Surface substrate mean cover values were largely organic $(97 \%)$ with minor amounts of decaying wood $(2 \%)$ and standing water $(1 \%)$. Picea mariana formed closed canopy stands with approximately $50 \%$ cover. Larix laricina was codominant with 3 to $10 \%$ cover and there was often some cover of Picea glauca, and Betula papyrifera. The medium and tall shrub layers had less than $10 \%$ cover consisting of Salix maccalliana, Picea mariana, Salix bebbiana, and other shrubs. The low shrub layer was thin with less than $5 \%$ cover composed of Ledum groenlandicum, Ribes triste, Cornus canadensis, and other shrubs. The herb layer was sparse yet had relatively high diversity of plant species with less than $1 \%$ cover each. These included Equisetum arvense, Mitella nuda, Petasites frigidus var palmatus, Rubus pubescens, and Equisetum fluviatile. Graminoids were present in trace amounts and included various Carex spp. and Calamagrostis canadensis. There was typically over $60 \%$ cover in the moss layer that consisted mainly of Pleurozium schreberi (55\%), and Hylocomium splendens (5\%). Other mosses included Sphagnum fuscum, Aulacomnium palustre, and Ptilium crista-castrensis. Peltigera aphthosa was often present.

Class: Forest

Subclass: Evergreen Forest

Group: Temperate or subpolar needle-leaved evergreen forest

Subgroup: Natural/Semi-natural temperate or subpolar needle-leaved evergreen forest

Formation: Saturated temperate or subpolar needle-leaved evergreen forest

Alliance: Picea mariana Saturated Forest

Association: Picea mariana - Larix laricina / Pleurozium schreberi Forest

Unique Identifier: $\mathrm{n} / \mathrm{a}$

Classification Confidence Level: 2 (Moderate) Only two plots were completed and there were several similar but not identical types described in the literature. Most communities include Ledum groenlandicum as part of the classification name for the plant association. Canopy closure in the two plots may have been higher than what was typical for this type reduced percent cover values observed in the shrub and herb/graminoid layers. This type was likely closely related to the Picea mariana - Larix laricina / Ledum groenlandicum / Pleurozium schreberi Forest. The current classification was likely widespread throughout the boreal region but its distribution was uncertain.

Dominant Species:_Picea mariana, Pleurozium schreberi, Usnea spp

Co-Dominant Species: Larix laricina, Picea glauca, Betula papyrifera, Salix maccalliana, Ledum groenlandicum, Hylocomium splendens

Diagnostic Species: Picea mariana, Cornus canadensis, Ledum groenlandicum, Equisetum arvense, Mitella nuda, Petasites frigidus var palmatus, Pleurozium schreberi, Hylocomium splendens, Peltigera aphthosa 
Table 19. Summary of plot data and descriptive statistics for the Picea mariana - Larix laricina / Pleurozium schreberi community type $(\mathrm{n}=2)$.

\begin{tabular}{|c|c|c|c|c|c|c|c|c|}
\hline \multirow[b]{2}{*}{ Strata } & \multirow[b]{2}{*}{ Code } & \multirow[b]{2}{*}{ Species } & \multicolumn{2}{|c|}{ Plots } & \multirow[b]{2}{*}{ Mean } & \multirow[b]{2}{*}{ SE } & \multirow[b]{2}{*}{ Constancy } & \multirow[b]{2}{*}{ Prominence } \\
\hline & & & P07 & P36 & & & & \\
\hline $\mathbf{M}$ & PLEUSCH & Pleurozium schreberi & 50.0 & 60.0 & 55.0 & 5.0 & 100.0 & 74.2 \\
\hline $\mathrm{T} 1$ & PICEMAR & Picea mariana & 50.0 & 50.0 & 50.0 & 0.0 & 100.0 & 70.7 \\
\hline $\mathrm{E}$ & USNEA\$\$\$ & Usnea spp. & 25.0 & 25.0 & 25.0 & 0.0 & 100.0 & 50.0 \\
\hline $\mathrm{T} 1$ & LARILAR & Larix laricina & 10.0 & 3.0 & 6.5 & 3.5 & 100.0 & 25.5 \\
\hline $\mathrm{E}$ & EPIPHYT & Epiphyte spp. & 0.0 & 25.0 & 12.5 & 12.5 & 50.0 & 25.0 \\
\hline $\mathrm{M}$ & HYLOSPL & Hylocomium splendens & 10.0 & 1.0 & 5.5 & 4.5 & 100.0 & 23.5 \\
\hline S1 & SALIMAC & Salix maccalliana & 0.0 & 9.0 & 4.5 & 4.5 & 50.0 & 15.0 \\
\hline S3 & LEDUGRO & Ledum groenlandicum & 1.0 & 3.0 & 2.0 & 1.0 & 100.0 & 14.1 \\
\hline S2 & PICEMAR & Picea mariana & 2.0 & 1.0 & 1.5 & 0.5 & 100.0 & 12.2 \\
\hline $\mathrm{T} 1$ & PICEGLA & Picea glauca & 5.0 & 0.0 & 2.5 & 2.5 & 50.0 & 11.2 \\
\hline $\mathrm{T} 2$ & BETUPAP & Betula papyrifera & 5.0 & 0.0 & 2.5 & 2.5 & 50.0 & 11.2 \\
\hline S1 & PICEMAR & Picea mariana & 0.0 & 3.0 & 1.5 & 1.5 & 50.0 & 8.7 \\
\hline $\mathrm{T} 1$ & PINUBAN & Pinus banksiana & 3.0 & 0.0 & 1.5 & 1.5 & 50.0 & 8.7 \\
\hline $\mathrm{T} 1$ & BETUPAP & Betula papyrifera & 0.0 & 2.0 & 1.0 & 1.0 & 50.0 & 7.1 \\
\hline $\mathrm{M}$ & SPHAFUS & Sphagnum fuscum & 0.0 & 2.0 & 1.0 & 1.0 & 50.0 & 7.1 \\
\hline S3 & RIBETRI & Ribes triste & 0.0 & 1.0 & 0.5 & 0.5 & 50.0 & 5.0 \\
\hline S1 & SALIBEB & Salix bebbiana & 1.0 & 0.0 & 0.5 & 0.5 & 50.0 & 5.0 \\
\hline $\mathrm{H}$ & PETAPAL & Petasites frigidus var palmatus & 0.1 & 0.1 & 0.1 & 0.0 & 100.0 & 3.2 \\
\hline $\mathrm{H}$ & EQUIARV & Equisetum arvense & 0.1 & 0.1 & 0.1 & 0.0 & 100.0 & 3.2 \\
\hline S3 & CORNCAN & Cornus canadensis & 0.1 & 0.1 & 0.1 & 0.0 & 100.0 & 3.2 \\
\hline $\mathrm{L}$ & PELTAPH & Peltigera aphthosa & 0.1 & 0.1 & 0.1 & 0.0 & 100.0 & 3.2 \\
\hline $\mathrm{H}$ & MITENUD & Mitella nuda & 0.1 & 0.1 & 0.1 & 0.0 & 100.0 & 3.2 \\
\hline S3 & VACCMYR & Vaccinium myrtilloides & 0.1 & 0.1 & 0.1 & 0.0 & 100.0 & 3.2 \\
\hline M & AULAPAL & Aulacomnium palustre & 0.1 & 0.1 & 0.1 & 0.0 & 100.0 & 3.2 \\
\hline S3 & GAULHIS & Gaultheria hispidula & 0.0 & 0.1 & 0.1 & 0.1 & 50.0 & 1.6 \\
\hline M & POLYPIL & Polytrichum piliferum & 0.0 & 0.1 & 0.1 & 0.1 & 50.0 & 1.6 \\
\hline S3 & LINNBOR & Linnaea borealis & 0.1 & 0.0 & 0.1 & 0.1 & 50.0 & 1.6 \\
\hline S3 & LONIINV & Lonicera involucrata & 0.0 & 0.1 & 0.1 & 0.1 & 50.0 & 1.6 \\
\hline S3 & AMELALN & Amelanchier alnifolia & 0.1 & 0.0 & 0.1 & 0.1 & 50.0 & 1.6 \\
\hline $\mathrm{L}$ & CLADONI & Cladonia spp. & 0.1 & 0.0 & 0.1 & 0.1 & 50.0 & 1.6 \\
\hline $\mathrm{M}$ & PTILCRI & Ptilium crista-castrensis & 0.1 & 0.0 & 0.1 & 0.1 & 50.0 & 1.6 \\
\hline S3 & RUBUPUB & Rubus pubescens & 0.1 & 0.0 & 0.1 & 0.1 & 50.0 & 1.6 \\
\hline $\mathrm{H}$ & GALIBOR & Galium boreale & 0.1 & 0.0 & 0.1 & 0.1 & 50.0 & 1.6 \\
\hline G & CARECAN & Carex canescens spp canescens & 0.0 & 0.1 & 0.1 & 0.1 & 50.0 & 1.6 \\
\hline $\mathrm{L}$ & ICMAERI & Icmadophila ericetorum & 0.0 & 0.1 & 0.1 & 0.1 & 50.0 & 1.6 \\
\hline M & MOSSES\$\$ & Unidentified Moss spp. & 0.1 & 0.0 & 0.1 & 0.1 & 50.0 & 1.6 \\
\hline M & DICRPOL & Dicranum polysetum & 0.0 & 0.1 & 0.1 & 0.1 & 50.0 & 1.6 \\
\hline $\mathrm{H}$ & VIOLREN & Viola renifolia & 0.1 & 0.0 & 0.1 & 0.1 & 50.0 & 1.6 \\
\hline $\mathrm{H}$ & FRAGVIR & Fragaria virginiana & 0.1 & 0.0 & 0.1 & 0.1 & 50.0 & 1.6 \\
\hline $\mathrm{H}$ & EQUIFLU & Equisetum fluviatile & 0.0 & 0.1 & 0.1 & 0.1 & 50.0 & 1.6 \\
\hline S3 & SALIMYR & Salix myrtillifolia & 0.1 & 0.0 & 0.1 & 0.1 & 50.0 & 1.6 \\
\hline $\mathrm{H}$ & EQUISCI & Equisetum scirpoides & 0.1 & 0.0 & 0.1 & 0.1 & 50.0 & 1.6 \\
\hline $\mathrm{H}$ & EPILANG & Epilobium angustifolium & 0.1 & 0.0 & 0.1 & 0.1 & 50.0 & 1.6 \\
\hline $\mathrm{H}$ & TRIEBOR & Trientalis borealis & 0.0 & 0.1 & 0.1 & 0.1 & 50.0 & 1.6 \\
\hline S1 & ALNUVIR & Alnus viridis & 0.1 & 0.0 & 0.1 & 0.1 & 50.0 & 1.6 \\
\hline G & CAREDIS & Carex disperma & 0.0 & 0.1 & 0.1 & 0.1 & 50.0 & 1.6 \\
\hline G & CALACAN & Calamagrostis canadensis & 0.1 & 0.0 & 0.1 & 0.1 & 50.0 & 1.6 \\
\hline S3 & VACCVIT & Vaccinium vitis-idaea & 0.0 & 0.1 & 0.1 & 0.1 & 50.0 & 1.6 \\
\hline $\mathrm{H}$ & HIERUMB & Hieracium umbellatum & 0.1 & 0.0 & 0.1 & 0.1 & 50.0 & 1.6 \\
\hline $\mathrm{H}$ & ARALNUD & Aralia nudicaulis & 0.1 & 0.0 & 0.1 & 0.1 & 50.0 & 1.6 \\
\hline $\mathrm{H}$ & SMILTRI & Smilacina trifolia & 0.0 & 0.1 & 0.1 & 0.1 & 50.0 & 1.6 \\
\hline $\mathrm{H}$ & RUBUACA & Rubus arcticus & 0.0 & 0.1 & 0.1 & 0.1 & 50.0 & 1.6 \\
\hline G & CARETEN & Carex tenuiflora & 0.0 & 0.1 & 0.1 & 0.1 & 50.0 & 1.6 \\
\hline $\mathrm{H}$ & CALTPAL & Caltha palustris & 0.0 & 0.1 & 0.1 & 0.1 & 50.0 & 1.6 \\
\hline $\mathrm{H}$ & ANEMPAR & Anemone parviflora & 0.0 & 0.1 & 0.1 & 0.1 & 50.0 & 1.6 \\
\hline $\mathrm{L}$ & CLADMIT & Cladina mitis & 0.1 & 0.0 & 0.1 & 0.1 & 50.0 & 1.6 \\
\hline
\end{tabular}




\section{Literature Review:}

Raup and Argus (1982) reported a Picea mariana / Ledum groenlandicum - Vaccinium vitis-idaea / Pleurozium schreberi mature forest that occurred in the Athabasca Lake sand dunes area. The only vascular plants recorded for this type were Ledum groenlandicum and Vaccinium vitis-idaea, which occurred as scattered plants. Mosses formed a thick carpet and included Pleurozium schreberi, Ptilium crista-castrensis, Orthodicranum montanum, Dicranum polysetum and Pohlia nutans. Allen et al. (2002, 2003) reported a Picea mariana / Pleurozium schreberi community type was present in the FidlerGreywillow and La Butte Creek Provincial Parks in northeastern Alberta. Trees were small in these stands and they occupied low areas in sandy undulating uplands. Another related type reported for this same area was a Picea mariana / Ledum groenlandicum / Pleurozium schreberi community type (Allen et al. 2003). Allen and Johnson (no date.) described a Picea mariana / Pleurozium schreberi community type from the Maybelle River Wildland Park. No details were provided regarding this type although it was located on terrace beside the Maybelle River and had some cover of Hylocomium splendens. Meijer (2002a) identified a Picea mariana / Ledum groenlandicum / Pleurozium schreberi community that occurred in this Park. There was no Larix laricina in this type and Ledum groenlandicum cover was dense (90\%). Mackenzie River Basin Committee (1981) identified a Picea mariana / Feather Moss community at Lake Athabasca. This community was similar to the ones described above. Ledum groenlandicum was the dominant shrub cover, although Alnus viridis may also be present. Dominant mosses included Pleurozium schreberi, Hylocomium splendens, and Dicranum polysetum.

Beckingham and Archibald (1996) described a Picea glauca - Picea mariana / Ledum groenlandicum / Feather Moss community type (h1.2) that occurred in the boreal mixedwood. In general this type was quite similar to the current type. The main differences in these types were the lower percent cover of Picea glauca in the overstorey, and lack of Populus tremuloides and Rosa acicularis in the shrub layer of the Holmes Crossing and North Buck Lake type. These were considered to be minor to moderate differences. Similarity ratings for related plant community types are provided in Table 20.

Table 20. Correlation table of plant community types with similarity ratings for the Picea mariana - Larix laricina / Pleurozium schreberi type.

\begin{tabular}{||l|c|l||}
\hline \multicolumn{1}{|c|}{ Similar Types } & $\begin{array}{c}\text { Similarity } \\
\text { Rating }\end{array}$ & \multicolumn{1}{|c||}{ Comments } \\
\hline \hline $\begin{array}{l}\text { Picea mariana / Ledum } \\
\text { groenlandicum - Vaccinium vitis- } \\
\text { idaea / Pleurozium schreberi CT } \\
\text { (Raup and Argus 1982) }\end{array}$ & 2 & $\begin{array}{l}\text { Lake Athabasca Lake sand dune type that has limited } \\
\text { plant diversity but was very similar to the current } \\
\text { classification. }\end{array}$ \\
\hline $\begin{array}{l}\text { Picea mariana / Pleurozium } \\
\text { schreberi CT (Allen } \text { et al. 2003) }\end{array}$ & 2 & $\begin{array}{l}\text { Similar type but no details available to make a direct } \\
\text { comparison. }\end{array}$ \\
\hline $\begin{array}{l}\text { Picea mariana / Pleurozium } \\
\text { schreberi CT (Allen and Johnson no } \\
\text { date) }\end{array}$ & $3(2)$ & $\begin{array}{l}\text { Possibly a similar type but no details regarding floristics } \\
\text { were available for review. }\end{array}$ \\
\hline $\begin{array}{l}\text { Picea mariana / Ledum } \\
\text { groenlandicum / Pleurozium } \\
\text { schreberi CT (Meijer 2002a) }\end{array}$ & 3 & $\begin{array}{l}\text { A similar type but percent covers of dominant species } \\
\text { was different from the current classification. }\end{array}$ \\
\hline $\begin{array}{l}\text { Picea glauca - Picea mariana / } \\
\text { Ledum groenlandicum / Feather } \\
\text { Moss CT (h1.2) (Beckingham and } \\
\text { Archibald 1996) }\end{array}$ & $2(1)$ & $\begin{array}{l}\text { This CT had a similar species composition, however, } \\
\text { there were differences in percent cover of the dominant } \\
\text { species. }\end{array}$ \\
\hline
\end{tabular}




\subsubsection{Picea mariana - Larix laricina Wet Forest Black Spruce - Tamarack Wet Forest}

The Picea mariana - Larix laricina Wet Forest stand sampled occupied a small depression that appeared to be flooding either repeatedly or for extended periods. The water table remains close to the surface over the entire year and soils were moderately well to imperfectly drained Organics. Moisture levels were typically mesic to subhygric and the soil nutrient regime was submesotrophic to mesotrophic. Surface substrates were predominantly organic ( $94 \%$ mean cover) and decaying wood $(6 \%)$ with a trace of standing water. This stand had a very closed overstorey of Picea mariana $(50 \%)$ and Larix laricina $(25 \%)$ with scattered Betula papyrifera (Table 21). The shrub layer was dominated by Picea mariana, Vaccinium vitis-idaea, and Linnaea borealis. The herb/graminoid layer was very sparse but included trace amounts of Orthilia secunda, Mitella nuda, and Carex spp. The moss layer had less than $7 \%$ cover consisting of Pleurozium schreberi, Hylocomium splendens, Sphagnum magellanicum, and other species. This was a small stand that was encountered only once and it was uncertain if it was a recurring type. It appeared that a significant portion of the moss layer had recently died off perhaps due to a recent water table draw down. There were several very small openings adjacent to this plot that had substantial cover of by Ledum groenlandicum and Caltha palustris associated with small pools of standing water.

Class: Forest

Subclass: Evergreen Forest

Group: Temperate or subpolar needle-leaved evergreen forest

Subgroup: Natural/Semi-natural temperate or subpolar needle-leaved evergreen forest

Formation: Saturated temperate or subpolar needle-leaved evergreen forest

Alliance: Picea mariana Saturated Forest

Association: Picea mariana - Larix laricina Wet Forest

Unique Identifier: $\mathrm{n} / \mathrm{a}$

Classification Confidence Level: 3 (Weak) Only one stand was encountered and there was no reference to this type in the literature. Geographical distribution was unknown.

Dominant Species: Picea mariana, Larix laricina

Co-Dominant Species: Betula papyrifera, Hylocomium splendens, Pleurozium schreberi

Diagnostic Species: Larix laricina, Picea mariana, Mitella nuda, Carex spp, Pleurozium schreberi, Hylocomium splendens

Table 21. Summary of plot data and descriptive statistics for the Picea mariana - Larix laricina Wet Forest $(\mathrm{n}=1)$.

\begin{tabular}{|c|c|c|c|}
\hline & & & Plot \\
\hline Strata & Code & Species & P35 \\
\hline $\mathrm{T} 2$ & PICEMAR & Picea mariana & 50.0 \\
\hline $\mathrm{T} 1$ & LARILAR & Larix laricina & 25.0 \\
\hline S1 & PICEMAR & Picea mariana & 15.0 \\
\hline M & PLEUSCH & Pleurozium schreberi & 4.0 \\
\hline $\mathrm{E}$ & EPIPHYT & Epiphyte spp. & 2.0 \\
\hline M & HYLOSPL & Hylocomium splendens & 1.0 \\
\hline $\mathrm{T} 2$ & BETUPAP & Betula papyrifera & 1.0 \\
\hline $\mathrm{H}$ & ORTHSEC & Orthilia secunda & 0.1 \\
\hline M & MOSSES\$ $\$$ & Moss spp. & 0.1 \\
\hline
\end{tabular}

\begin{tabular}{|c|c|c|c|}
\hline \multirow[b]{2}{*}{ Strata } & \multirow[b]{2}{*}{ Code } & \multirow[b]{2}{*}{ Species } & \multirow{2}{*}{$\begin{array}{l}\text { Plot } \\
\text { P35 }\end{array}$} \\
\hline & & & \\
\hline M & SPHAMAG & $\begin{array}{l}\text { Sphagnum } \\
\text { magellanicum }\end{array}$ & 0.1 \\
\hline $\mathrm{L}$ & CLADONI & Cladonia spp. & 0.1 \\
\hline G & CARELEP & Carex leptalea & 0.1 \\
\hline M & POLYPIL & Polytrichum piliferum & 0.1 \\
\hline G & CAREDIS & Carex disperma & 0.1 \\
\hline $\mathrm{H}$ & MITENUD & Mitella nuda & 0.1 \\
\hline S3 & VACCVIT & Vaccinium vitis-idaea & 0.1 \\
\hline $\mathrm{H}$ & CALTPAL & Caltha palustris & 0.1 \\
\hline S3 & LINNBOR & Linnaea borealis & 0.1 \\
\hline
\end{tabular}

Literature Review:

No similar types were reviewed for this type. 


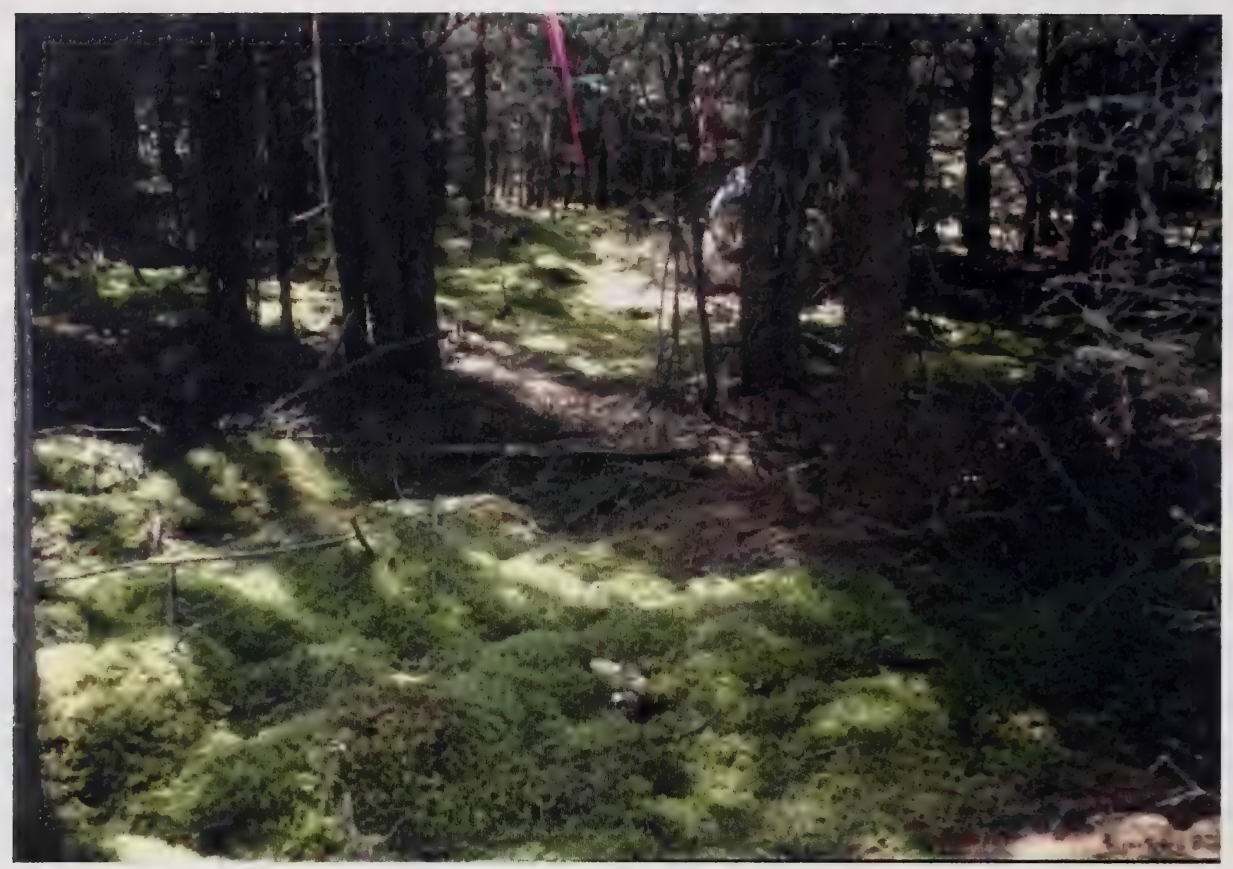

Plate 10. Picea mariana - Larix laricina / Pleurozium schreberi Forest (P7).

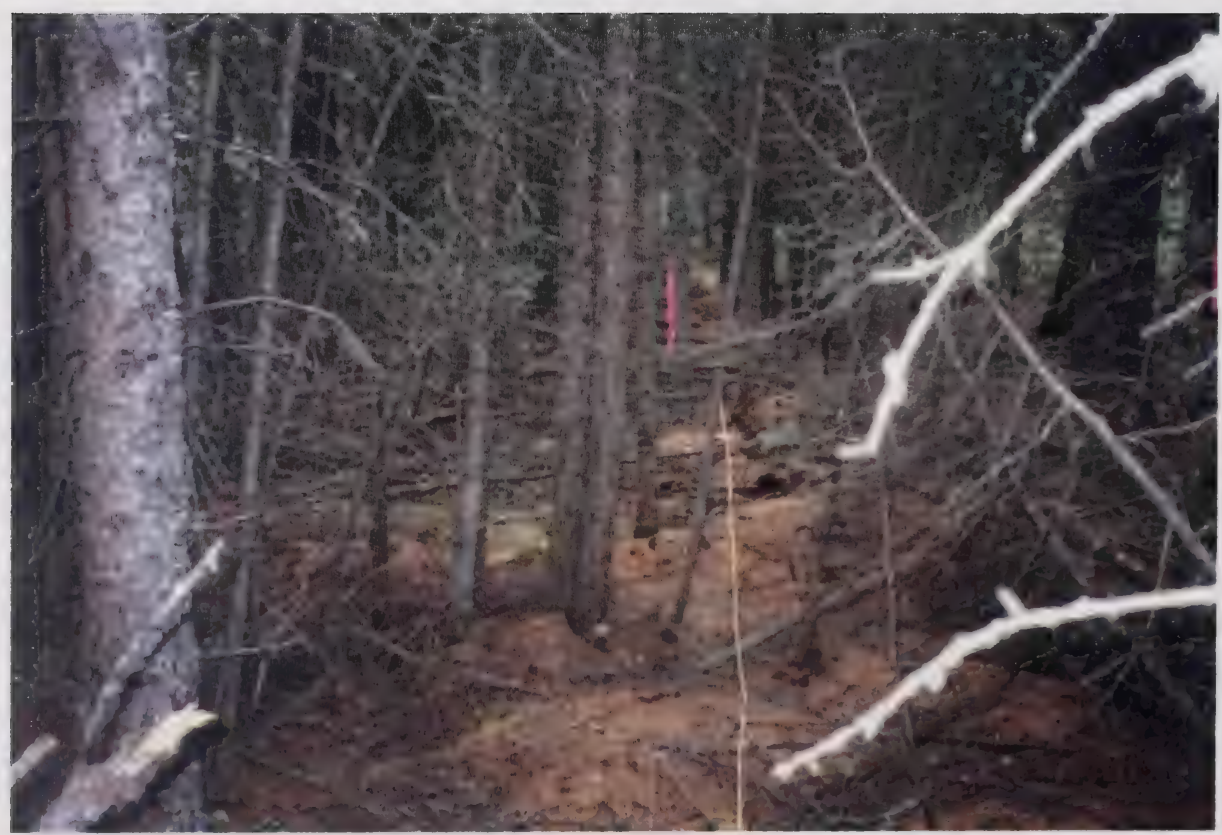

Plate 11. Picea mariana - Larix laricina Wet Forest (P35). 


\subsubsection{Larix laricina / Betula pumila / Equisetum fluviatile Forest}

Tamarack / Dwarf Birch / Swamp Horsetail Forest

One plot was completed for this type in the Holmes Crossing Sandhills Ecological Reserve (Table 22). It was not encountered elsewhere and it was not known how common it was in either study area. The stand sampled occurred in a lowland depression that may be seasonally flooded. This was a level site and soils were poorly drained Organics with hydric moisture levels and a submesotrophic nutrient regime. Surface substrates were predominately organic matter with minor amounts of decaying wood and some standing water $(<5 \%)$. Larix laricina forms and open canopy in the overstorey and was an important component of all other shrub layers. Betula pumila cover was very high at $70 \%$ followed by Ledum groenlandicum (10\%). A variety of other shrubs were present including Vaccinium vitis-idaea, Andromeda polifolia, and Oxycoccus microcarpus. Dominant herb cover included Equisetum fluviatile (50\%), Menyanthes trifoliata (40\%), and Potentilla palustris (8\%). Other species in the herb/graminoid layer included Tofieldia glutinosa, Rubus arcticus, Carex diandra, Galium labradoricum, Carex spp., and others. Tomentypnum nitens was cover was $80 \%$ and a variety of other mosses including Aulacomnium palustre occurred in this type. Note that no colour plate was available for plot 15 .

Class: Forest

Subciass: Deciduous forest

Group: Cold-deciduous forest

Subgroup: Natural/Semi-natural

Formation: Intermittently Flooded Temperate or Subpolar Cold-deciduous Woodland

Alliance: Larix laricina Saturated Forest Alliance

Association: Larix laricina / Betula pumila / Equisetum fluviatile Forest

Unique Identifier: $n / a$

Classification Confidence Level: 2 (Moderate) Only one plot completed but there was a relatively good correlation to other documented types in the literature. It was likely common throughout the boreal region.

Dominant Species: Larix laricina, Betula pumila, Equisetum fluviatile, Menyanthes trifoliata, Tomentypnum nitens, Usnea spp.

Co-Dominant Species: Ledum groenlandicum, Vaccinium vitis-idaea, Andromeda polifolia, Galium labradoricum, Potentilla palustris, Carex spp, Aulacomnium palustre

Diagnostic Species: Larix laricina, Betula pumila, Ledum groenlandicum, Oxycoccus microcarpus, Andromeda polifolia, Equisetum fluviatile, Menyanthes trifoliata, Potentilla palustris, Tofieldia glutinosa, Rubus arcticus, Carex diandra, Tomentypnum nitens, Aulacomnium palustre

\section{Literature Review:}

Beckingham and Archibald (1996) identified a Larix laricina / Betula pumila / Carex / Tomentypnum nitens community (k.1.1) that occurred in the boreal mixedwood. All species listed for this type were recorded for the present classification with the exception of Picea mariana, Smilacina trifolia, Caltha palustris, Calamagrostis canadensis, and Pleurozium schreberi. The Holmes Crossing plot also had more Menyanthes trifoliata and substantial cover of Equisetum fluviatile. The entire species list was not provided for this k.1.1 community and these were not considered to be major differences.

NatureServe (2004) lists a Larix laricina / Carex aquatilis Herbaceous Vegetation (CEGL002533) that was ranked GNR. It was found north of the boreal zone in Manitoba (Greenall 1996) but few details were available for this review and this was considered a weak concept at this point requiring range-wide review. Larix laricina cover was $10-25 \%$ often only 4 to $5 \mathrm{~m}$ tall ranging to $10 \mathrm{~m}$ tall. Similarity ratings for related plant community types are provided in Table 23. 
Table 22. Summary of plot data and descriptive statistics for the Larix laricina / Betula pumila / Equisetum fluviatile community type $(\mathrm{n}=1)$.

\begin{tabular}{|c|c|c|c|}
\hline & & & Plot \\
\hline Strata & Code & Species & P15 \\
\hline M & TOMENIT & Tomentypnum nitens & 80.0 \\
\hline $\mathrm{S} 2$ & BETUPUM & Betula pumila & 70.0 \\
\hline $\mathrm{E}$ & USNEA\$\$\$ & Usnea spp. & 60.0 \\
\hline $\mathrm{H}$ & EQUIFLU & Equisetum fluviatile & 50.0 \\
\hline $\mathrm{H}$ & MENYTRI & Menyanthes trifoliata & 40.0 \\
\hline T1 & LARILAR & Larix laricina & 20.0 \\
\hline $\mathrm{S} 2$ & LARILAR & Larix laricina & 15.0 \\
\hline S1 & LARILAR & Larix laricina & 10.0 \\
\hline S3 & LEDUGRO & Ledum groenlandicum & 10.0 \\
\hline $\mathrm{H}$ & POTEPAL & Potentilla palustris & 8.0 \\
\hline S3 & VACCVIT & Vaccinium vitis-idaea & 8.0 \\
\hline G & CAREDIA & Carex diandra & 7.0 \\
\hline M & AULAPAL & Aulacomnium palustre & 6.0 \\
\hline S3 & LARILAR & Larix laricina & 5.0 \\
\hline S3 & ANDRPOL & Andromeda polifolia & 5.0 \\
\hline $\mathrm{H}$ & GALILAB & Galium labradoricum & 4.0 \\
\hline M & DREPADU & $\begin{array}{l}\text { Drepanocladus } \\
\text { aduncus }\end{array}$ & 4.0 \\
\hline
\end{tabular}

\begin{tabular}{|cllc|}
\hline & & \multicolumn{1}{c}{ Species } & Plot \\
\cline { 4 - 4 } Strata & \multicolumn{1}{c}{ Code } & P15 \\
\hline H & FRAGVIR & Fragaria virginiana & 4.0 \\
S3 & VACCMYR & Vaccinium myrtilloides & 3.0 \\
S3 & SALIPED & Salix pedicellaris & 3.0 \\
M & SPHAFUS & Sphagnum fuscum & 3.0 \\
G & CAREINT & Carex interior & 2.0 \\
G & CARECHO & Carex chordorrhiza & 1.0 \\
S2 & SALICAN & Salix candida & 1.0 \\
L & CLADONI & Cladonia spp. & 1.0 \\
G & TRIGMAR & Triglochin maritima & 0.1 \\
S3 & OXYCMIC & Oxycoccus microcarpus & 0.1 \\
G & CAREDIS & Carex disperma & 0.1 \\
H & TOFIGLU & Tofieldia glutinosa & 0.1 \\
H & RUBUACA & Rubus arcticus & 0.1 \\
H & HABEHYP & Platanthera hyperborea & 0.1 \\
H & CORATRI & Corallorhiza trifida & 0.1 \\
M & MOSS\$\$ & Unidentified Moss & 0.1 \\
& & & \\
\hline & & & \\
\hline
\end{tabular}

Table 23. Correlation table of plant community types with similarity ratings for the Larix laricina / Betula pumila / Equisetum fluviatile type.

\begin{tabular}{||l|c|l||}
\hline \multicolumn{1}{|c|}{ Similar Types } & $\begin{array}{c}\text { Similarity } \\
\text { Rating }\end{array}$ & \multicolumn{1}{|c||}{ Comments } \\
\hline $\begin{array}{l}\text { Larix laricina / Betula pumila / } \\
\text { Carex / Tomentypnum nitens CT } \\
\text { (k.1.1) (Beckingham and Archibald } \\
\text { 1996) }\end{array}$ & $1(2)$ & $\begin{array}{l}\text { Similar site conditions and appears to be the same type } \\
\text { although there were some differences in the plant } \\
\text { composition. }\end{array}$ \\
\hline $\begin{array}{l}\text { Larix laricina / Carex aquatilis } \\
\text { Herbaceous Vegetation } \\
\text { (CEGL002533) (NatureServe 2004) }\end{array}$ & 3 & $\begin{array}{l}\text { Few details available for review and this type occurred } \\
\text { north of the boreal zone. }\end{array}$ \\
\hline
\end{tabular}

\subsubsection{Populus tremuloides / Corylus cornuta / Aralia nudicaulis Forest Aspen / Beaked Hazelnut / Sarsaparilla Forest}

This plant community was observed in the southern portion of the North Buck Lake study area only. The one plot completed was on a mid-slope position with a very gentle slope gradient (6\%) (Table 24$)$. Soils were well drained with mesic moisture conditions and permesotrophic (rich) nutrient levels. The closed overstorey canopy was dominated by Populus tremuloides. The shrub layer was relatively diverse mainly consisting of Corylus cornuta (40\%), Rosa acicularis (7\%), Viburnum edule (7), Salix bebbiana (6\%), 
Amelanchier alnifolia (5\%), and a variety of other shrubs. The herbaceous layer had approximately $20 \%$ cover consisting mainly of Aralia nudicaulis, Disporum trachycarpum, Lathyrus ochroleucus, Mertensia paniculata, Thalictrum venulosum, and Calamagrostis canadensis.

Class: Forest

Subclass: Deciduous forest

Group: Cold-deciduous forest

Subgroup: Natural/Semi-natural cold-deciduous forest

Formation: Montane or boreal cold-deciduous forest

Alliance: Populus tremuloides Forest Alliance

Association: Populus tremuloides / Corylus cornuta / Aralia nudicaulis Forest

Unique Identifier: $\mathrm{n} / \mathrm{a}$

Classification Confidence Level: 1 (Strong) A distinct type that was relatively well documented in the literature. This was likely a widespread type in the southern boreal region but exact range was uncertain.

Dominant Species: Populus tremuloides, Corylus cornuta, Aralia nudicaulis

Co-Dominant Species: Rosa acicularis, Viburnum edule, Salix bebbiana, Lathyrus ochroleucus, Amelanchier alnifolia, Calamagrostis canadensis

Diagnostic Species: Populus tremuloides, Corylus cornuta, Aralia nudicaulis,

Disporum trachycarpum, Lathyrus ochroleucus, Mertensia paniculata, Thalictrum venulosum

Table 24. Summary of plot data and descriptive statistics for the Populus tremuloides / Corylus cornuta / Aralia nudicaulis community type $(\mathrm{n}=1)$.

\begin{tabular}{|c|c|c|c|c|c|c|c|}
\hline & & & Plot & & & & Plot \\
\hline Strata & Code & Species & 52 & Strata & Code & Species & 52 \\
\hline $\mathrm{T} 1$ & POPUTRE & Populus tremuloides & 50.0 & G & ORYZPUN & Oryzopsis pungens & 0.1 \\
\hline S2 & CORYCOR & Corylus cornuta & 40.0 & $\mathrm{H}$ & MAIACAN & $\begin{array}{l}\text { Maianthemum } \\
\text { canadense }\end{array}$ & 0.1 \\
\hline $\mathrm{H}$ & ARALNUD & Aralia nudicaulis & 16.0 & $\mathrm{H}$ & PYROASA & Pyrola asarifolia & 0.1 \\
\hline S2 & ROSAACI & Rosa acicularis & 7.0 & $\mathrm{H}$ & GALIBOR & Galium boreale & 0.1 \\
\hline S2 & VIBUEDU & Viburnum edule & 7.0 & $\mathrm{H}$ & EQUISYL & Equisetum sylvaticum & 0.1 \\
\hline $\mathrm{S} 1$ & SALIBEB & Salix bebbiana & 6.0 & $\mathrm{H}$ & EQUIARV & Equisetum arvense & 0.1 \\
\hline S1 & AMELALN & Amelanchier alnifolia & 5.0 & S3 & LINNBOR & Linnaea borealis & 0.1 \\
\hline S1 & POPUTRE & Populus tremuloides & 2.0 & S3 & LONIDIO & Lonicera dioica & 0.1 \\
\hline G & CALACAN & $\begin{array}{l}\text { Calamagrostis } \\
\text { canadensis }\end{array}$ & 1.0 & $\mathrm{H}$ & PETAPAL & $\begin{array}{l}\text { Petasites frigidus var } \\
\text { palmatus }\end{array}$ & 0.1 \\
\hline $\mathrm{H}$ & LATHOCH & Lathyrus ochroleucus & 1.0 & $\mathrm{H}$ & MERTPAN & Mertensia paniculata & 0.1 \\
\hline H & FRAGVIR & Fragaria virginiana & 1.0 & $\mathrm{H}$ & APOCAND & $\begin{array}{l}\text { Apocynum } \\
\text { androsaemifolium }\end{array}$ & 0.1 \\
\hline S3 & CORNCAN & Cornus canadensis & 1.0 & $\mathrm{H}$ & VICIAME & Vicia americana & 0.1 \\
\hline S3 & RUBUIDA & Rubus idaeus & 1.0 & G & CARESIC & Carex siccata & 0.1 \\
\hline $\mathrm{H}$ & PYROCHL & Pyrola chlorantha & 0.1 & H & THALVEN & Thalictrum venulosum & 0.1 \\
\hline S3 & RUBUPUB & Rubus pubescens & 0.1 & $\mathrm{H}$ & DISPTRA & Disporum trachycarpum & 0.1 \\
\hline $\mathrm{H}$ & ORTHSEC & Orthilia secunda & 0.1 & $\mathrm{H}$ & ASTECIL & Aster ciliolatus & 0.1 \\
\hline $\mathrm{H}$ & ASTECON & Aster conspicuus & 0.1 & S1 & BETUPAP & Betula papyrifera & 0.1 \\
\hline $\mathrm{H}$ & EPILANG & $\begin{array}{l}\text { Epilobium } \\
\text { angustifolium }\end{array}$ & 0.1 & G & ELYMINN & Leymus innovatus & 0.1 \\
\hline $\mathrm{H}$ & ACTARUB & Actaea rubra & 0.1 & & & & \\
\hline
\end{tabular}




\section{Literature:}

Allen (2004) lists a Populus tremuloides / Salix bebbiana - Corylus cornuta / Calamagrostis canadensis Matteuccia struthiopteris community type (CEAB000045) that was ranked S1 in Alberta. It occupies riparian wet meadow sites in the Central Mixedwood Natural Subregion that were imperfectly drained with hygric moisture regimes (Timoney and Robinson 1998). Large fluctuations in the water table resulting from stream flooding and possibly beaver activity directly influence stand composition. Typically the Populus tremuloides canopy was open with approximately $10 \%$ cover in the tall shrub layer and $17 \%$ in the low shrub layer. Calamagrostis canadensis cover was approximately $45 \%$ and Matteuccia struthiopteris cover was approximately $25 \%$. This type appeared similar to the current classification. However, the North Buck Lake community was a closed canopy forest on well-drained soils with a mesic moisture regime. No flooding hazard was expected at this site. In addition, Calamagrostis canadensis cover was only $1 \%$ and there was no cover of Matteuccia struthiopteris recorded for this plot.

Downing and Karpuk (1992) described a Populus tremuloides / Corylus cornuta / Aralia nudicaulis Vegetation Type for the Low Boreal Mixedwood Ecoregion of East-central Alberta. This type appears to be a very similar to identical plant community type that commonly occurred on sandy clay loam soils. Virtually all species listed for this type also occurred in the current plot with the exception of Populus balsamifera, Prunus spp., Rosa woodsii, Symphoricarpos albus and a few others. These were not considered to be significant differences and most differences were likely the result of the small sample size on the current study. This type was also described by Beckingham and Archibald (1996) as a Populus tremuloides / Corylus cornuta plant community (d1.3) that occurred in the boreal mixedwood. This type also appears to be very similar to the community inventoried in the North Buck Lake study area. The only difference was a lack of Populus balsamifera, Picea glauca, Prunus spp. and Symphoricarpos albus in the current community type. Again the lack of these species was considered a minor difference and can likely be attributed to the small sample size.

\section{Coenen (2003) described a Populus balsamifera / Corylus cornuta - Cornus stolonifera / Aralia}

nudicaulis community from the Wainwright Dunes Ecological Reserve. Species composition was virtually identical to the North Buck Lake community with the exception of Populus tremuloides as the dominant tree species and the lack of Cornus stolonifera cover in the plot completed on the current study. Populus tremuloides $\mathrm{X}$ P. balsamifera hybrids were noted in several areas within the boreal sand dunes and it was possible that these were present at the one plot sampled. Also Cornus stolonifera was relatively common in the boreal sand dunes and additional sampling may indicate that this species was a component of this community as well. The key differences in floristics were most likely attributable to the wetter moisture regime of the Wainwright plots in comparison to the North Buck Lake plot. Cottonwood Consultants Ltd (1986) also identified a similar aspen forest that occurred in moister depressions. Important shrub included choke cherry, saskatoon, beaked hazelnut, red osier dogwood, wild red raspberry, and snowberry. Herbs included northern bedstraw, pink wintergreen, dewberry, veiny meadowrue, and western Canada violet.

NatureServe (2004) lists a Populus tremuloides / Corylus cornuta Forest (CEGL000583) found in Colorado, Wyoming, the Dakotas, and southern Saskatchewan. It occurred on a variety of aspects, usually northerly facing and well-developed, deep soils. Populus tremuloides forms a closed canopy and Betula papyrifera may be codominant. Quercus macrocarpa, Fraxinus pennsylvanica, Picea glauca, and Pinus ponderosa may also be present. The shrub and forb layers were well developed. Important shrubs include Corylus cornuta, Amelanchier alnifolia, Mahonia repens, Prunus virginiana, Symphoricarpos spp., and Rubus idaeus. In the herb layer important species include Aralia nudicaulis, Lathyrus ochroleucus, Maianthemum canadense, Galium triflorum, Maianthemum stellatum, Viola spp., and Sanicula marilandica. Graminoid cover was light but Carex pensylvanica may be common in eastern stands. Similarity ratings for related plant community types are provided in Table 25. 
Table 25. Correlation table of plant community types with similarity ratings for the Populus tremuloides / Corylus cornuta / Aralia nudicaulis type.

\begin{tabular}{|l|c|l||}
\hline \multicolumn{1}{|c|}{ Similar Types } & $\begin{array}{c}\text { Similarity } \\
\text { Rating }\end{array}$ & \multicolumn{1}{c|}{ Comments } \\
\hline $\begin{array}{l}\text { Populus tremuloides / Salix bebbiana } \\
\text { - Corylus cornuta / Calamagrostis } \\
\text { canadensis -Matteuccia struthiopteris } \\
\text { CT (CEAB000045) (Allen 2004) }\end{array}$ & 3 & $\begin{array}{l}\text { This type would share the same alliance but based on } \\
\text { floristics and ecological niche was determined to be } \\
\text { different communities. }\end{array}$ \\
\hline $\begin{array}{l}\text { Populus tremuloides / Corylus } \\
\text { cornuta / Aralia nudicaulis CT } \\
\text { (Downing and Karpuk 1992) }\end{array}$ & 1 & $\begin{array}{l}\text { Appears to be an identical plant community that } \\
\text { occurred on similar sites. }\end{array}$ \\
\hline $\begin{array}{l}\text { Populus tremuloides / Corylus } \\
\text { cornuta CT (d1.3) (Beckingham and } \\
\text { Archibald 1996) }\end{array}$ & 1 & $\begin{array}{l}\text { Very similar site conditions and plant community } \\
\text { composition. }\end{array}$ \\
\hline $\begin{array}{l}\text { Populus balsamifera / Corylus } \\
\text { cornuta - Cornus stolonifera / Aralia } \\
\text { nudicaulis CT (Coenen 2003) }\end{array}$ & 2 & $\begin{array}{l}\text { Virtually identical community type but it occurred on } \\
\text { wetter sites. }\end{array}$ \\
\hline $\begin{array}{l}\text { Aspen Woodland (Cottonwood } \\
\text { Consultants Ltd. 1986) }\end{array}$ & 3 & $\begin{array}{l}\text { A broad description of this type was provided but no } \\
\text { percent covers. However, it seems to be a similar type. }\end{array}$ \\
\hline $\begin{array}{l}\text { Populus tremuloides / Corylus } \\
\text { cornuta Forest (CEGL000583) } \\
\text { (NatureServe 2004) }\end{array}$ & 2 & $\begin{array}{l}\text { Appears to have very similar floristics however it } \\
\text { features a number of species not found in the boreal sand } \\
\text { dunes. }\end{array}$ \\
\hline
\end{tabular}

\subsubsection{Populus tremuloides / Vaccinium myrtilloides / Arctostaphylos uva-ursi Forest Aspen / Common Blueberry / Bearberry Forest}

This community type was more common in the North Buck Lake study area where it was frequently encountered. Two samples were completed at North Buck Lake (Table 26). Sites were located on broad dune crests to upper slope positions that were nearly level to gentle slopes ranging between $4 \%$ and $16 \%$ slope gradients. Soils were typically loamy fine sands that were well drained with mesic soil moisture levels and a mesotrophic nutrient regime. Surface substrate groundcover was predominately organic matter, with less than $1 \%$ mineral soil and under 5\% decaying wood. The overstorey had $10 \%$ to $40 \%$ cover of Populus tremuloides and sometimes included scattered Betula papyrifera and Picea glauca. The mid and upper shrub layers had low percent cover values. The low shrub layer had about $75 \%$ cover that consisted mainly of Vaccinium myrtilloides (42\%), Vaccinium vitis-idaea (14\%), Arctostaphylos uva-ursi (8\%), Rosa acicularis, and Ledum groenlandicum. The herb and graminoid layers were diverse and included Lathyrus ochroleucus, Maianthemum canadense, Trientalis borealis, Oryzopsis pungens, and Leymus innovatus.

\section{Class: Forest}

Subclass: Deciduous forest

Group: Cold-deciduous forest

Subgroup: Natural/Semi-natural cold-deciduous forest

Formation: Montane or boreal cold-deciduous forest

Alliance: Populus tremuloides Forest Alliance

Association: Populus tremuloides / Vaccinium myrtilloides / Arctostaphylos uva-ursi Forest

Unique Identifier: $\mathrm{n} / \mathrm{a}$

Classification Confidence Level: 2 (Moderate) This was a recognisable type in the North Buck Lake study area but there was considerable variability between stands and it was not well documented in the literature. This type may have a relatively restricted range. 
Dominant Species: Populus tremuloides, Arctostaphylos uva-ursi, Vaccinium myrtilloides, Vaccinium vitis-idaea, Maianthemum canadense, Leymus innovatus

Co-Dominant Species: Betula papyrifera, Ledum groenlandicum, Rosa acicularis, Cornus canadensis, Calamagrostis canadensis, Carex siccata, Oryzopsis pungens, Cladina mitis

Diagnostic Species: Populus tremuloides, Betula papyrifera, Rosa acicularis, Vaccinium myrtilloides, Arctostaphylos uva-ursi, Cornus canadensis, Lathyrus ochroleucus, Maianthemum canadense, Trientalis borealis, Oryzopsis pungens

\section{Literature Review:}

Beckingham and Archibald (1996) identified a Pinus banksiana - Populus tremuloides / Vaccinium myrtilloides - Arctostaphylos uva-ursi plant community (b1.1) found in the boreal mixedwood. This type was similar to the current classification. The only diagnostic species listed for this type that was not recorded on the North Buck Lake plots was Picea mariana. Stands sampled on the current study were more open and had less Pinus banksiana and Shepherdia canadensis cover.

Downing and Karpuk (1992) described a Populus tremuloides / Rosa spp. - Vaccinium spp. vegetation type that was scattered throughout the Low Boreal Mixedwood Ecoregion. It occurred on dry, rapidly to well-drained sites that had sandy to stony textured soils. The plant species composition of this community was very similar to the current classification. However, this plant community has a more closed canopy layer and there were some differences in percent cover values of the dominant species. Petasites palmatus was listed as a co-dominant species for this type but was not recorded during the current study.

Coenen (2003) identified a Populus tremuloides / Prunus virginiana - Amelanchier / Carex siccata community type in the Wainwright Dunes Ecological Reserve. Plant species in common between this type and the current classification included Populus tremuloides, Amelanchier alnifolia, Rosa acicularis, Arctostaphylos uva-ursi, Maianthemum canadense, Lathyrus ochroleucus, and several others. However, this community did not include Betula papyrifera, Vaccinium myrtilloides, Vaccinium vitis-idaea, Cornus canadensis, Trientalis borealis, Oryzopsis pungens, Leymus innovatus, and other important species found in the North Buck Lake plots.

NatureServe (2004) lists a Populus (tremuloides, balsamifera) - (Betula papyrifera) - Picea mariana / Alnus viridis Forest (CEGL002514) that was ranked GNR. This community was found in the boreal regions of central and eastern Canada, including Manitoba (Greenall 1996), and may extend into adjacent areas of the United States. The overstorey was dominated by Populus tremuloides and Populus balsamifera in various mixtures and often included scattered Betula papyrifera and Picea mariana. The moss layer was dominated by Pleurozium schreberi.

NatureServe (2004) describes a Populus tremuloides - Betula papyrifera / (Abies balsamea, Picea glauca) Forest (CEGL002466) that was found in the boreal regions. It was reported to occur in Manitoba, Ontario, possibly Quebec, and adjacent areas in the United States. Site positions include ridgetops and gentle to moderate upper to lower slopes. Soils were well to rapidly drained with dry to mesic moisture conditions. Soil textures were typically clay loamy, silt or fine sand. The overstorey was dominated by Betula papyrifera and Populus tremuloides, with some Populus grandidentata. The understorey canopy included Abies halsamea and Picea glauca. Important shrubs include Acer spicatum, Corylus cornuta, Diervilla lonicera, Linnaea borealis, Lonicera canadensis, Rosa acicularis, Rubus pubescens, Sorbus decora, and Vaccinium myrtilloides. The herb layer consisted mainly of Aster macrophyllus. Other typical herbs include Anemone quinquefolia, Aralia nudicaulis, Clintonia borealis, Cornus canadensis, Galium triflorum, Maianthemum canadense, Mitella nuda, Pteridium aquilinum, Streptopus roseus, Trientalis borealis, and Viola renifolia. Mosses include Plagiomnium cuspidatum, Pleurozium schreberi, Ptilium crista-castrensis, and Rhytidiadelphus triquetrus. Similarity ratings for related plant community types are provided in Table 27. 
Table 26. Summary of plot data and descriptive statistics for the Populus tremuloides / Vaccinium myrtilloides / Arctostaphylos uva-ursi community type $(\mathrm{n}=3)$.

\begin{tabular}{|c|c|c|c|c|c|c|c|c|c|}
\hline \multirow[b]{2}{*}{ Strata } & \multirow[b]{2}{*}{ Code } & \multirow[b]{2}{*}{ Species } & \multicolumn{3}{|c|}{ Plots } & \multirow[b]{2}{*}{ Mean } & \multirow[b]{2}{*}{ SE } & \multirow[b]{2}{*}{ Constancy } & \multirow[b]{2}{*}{ Prominence } \\
\hline & & & P55 & P60 & P64 & & & & \\
\hline S3 & VACCMYR & Vaccinium myrtilloides & 35.0 & 50.0 & 40.0 & 41.7 & 4.4 & 100.0 & 64.5 \\
\hline $\mathrm{T} 1$ & POPUTRE & Populus tremuloides & 10.0 & 7.0 & 40.0 & 19.0 & 10.5 & 100.0 & 43.6 \\
\hline S3 & VACCVIT & Vaccinium vitis-idaea & 18.0 & 0.0 & 25.0 & 14.3 & 7.4 & 66.7 & 30.9 \\
\hline S3 & ARCTUVA & Arctostaphylos uva-ursi & 1.0 & 20.0 & 4.0 & 8.3 & 5.9 & 100.0 & 28.9 \\
\hline $\mathrm{H}$ & MAIACAN & Maianthemum canadense & 10.0 & 5.0 & 0.1 & 5.0 & 2.9 & 100.0 & 22.4 \\
\hline G & ELYMINN & Leymus innovatus & 5.0 & 15.0 & 0.0 & 6.7 & 4.4 & 66.7 & 21.1 \\
\hline S3 & ROSAACI & Rosa acicularis & 1.0 & 10.0 & 0.1 & 3.7 & 3.2 & 100.0 & 19.2 \\
\hline $\mathrm{G}$ & CARESIC & Carex siccata & 0.1 & 10.0 & 0.1 & 3.4 & 3.3 & 100.0 & 18.4 \\
\hline G & CALACAN & Calamagrostis canadensis & 15.0 & 0.0 & 0.1 & 5.0 & 5.0 & 66.7 & 18.3 \\
\hline G & ORYZPUN & Oryzopsis pungens & 0.1 & 7.0 & 0.1 & 2.4 & 2.3 & 100.0 & 15.5 \\
\hline S3 & LEDUGRO & Ledum groenlandicum & 1.0 & 0.0 & 9.0 & 3.3 & 2.8 & 66.7 & 14.9 \\
\hline $\mathrm{L}$ & CLADMIT & Cladina mitis & 0.0 & 0.1 & 8.0 & 2.7 & 2.7 & 66.7 & 13.4 \\
\hline S3 & CORNCAN & Cornus canadensis & 3.0 & 0.1 & 2.0 & 1.7 & 0.9 & 100.0 & 13.0 \\
\hline $\mathrm{S} 1$ & BETUPAP & Betula papyrifera & 3.0 & 1.0 & 0.0 & 1.3 & 0.9 & 66.7 & 9.4 \\
\hline S2 & POPUTRE & Populus tremuloides & 0.1 & 3.0 & 0.0 & 1.0 & 1.0 & 66.7 & 8.3 \\
\hline $\mathrm{H}$ & TRIEBOR & Trientalis borealis & 3.0 & 0.1 & 0.0 & 1.0 & 1.0 & 66.7 & 8.3 \\
\hline $\mathrm{H}$ & ASTECIL & Aster ciliolatus & 0.0 & 6.0 & 0.0 & 2.0 & 2.0 & 33.3 & 8.2 \\
\hline S3 & LINNBOR & Linnaea borealis & 2.0 & 1.0 & 0.0 & 1.0 & 0.6 & 66.7 & 8.2 \\
\hline M & PLEUSCH & Pleurozium schreberi & 0.1 & 2.0 & 0.0 & 0.7 & 0.7 & 66.7 & 6.8 \\
\hline S2 & BETUPAP & Betula papyrifera & 0.0 & 0.0 & 4.0 & 1.3 & 1.3 & 33.3 & 6.7 \\
\hline $\mathrm{T} 1$ & BETUPAP & Betula papyrifera & 1.0 & 0.0 & 1.0 & 0.7 & 0.3 & 66.7 & 6.7 \\
\hline $\mathrm{H}$ & EPILANG & Epilobium angustifolium & 0.1 & 1.0 & 0.0 & 0.4 & 0.3 & 66.7 & 4.9 \\
\hline $\mathrm{E}$ & EPIPHYT & Epiphyte spp. & 0.1 & 0.0 & 1.0 & 0.4 & 0.3 & 66.7 & 4.9 \\
\hline $\mathrm{T} 1$ & PINUBAN & Pinus banksiana & 2.0 & 0.0 & 0.0 & 0.7 & 0.7 & 33.3 & 4.7 \\
\hline $\mathrm{S} 1$ & POPUTRE & Populus tremuloides & 0.0 & 2.0 & 0.0 & 0.7 & 0.7 & 33.3 & 4.7 \\
\hline $\mathrm{H}$ & FRAGVIR & Fragaria virginiana & 0.0 & 1.0 & 0.0 & 0.3 & 0.3 & 33.3 & 3.3 \\
\hline $\mathrm{H}$ & EQUIPRA & Equisetum pratense & 0.0 & 1.0 & 0.0 & 0.3 & 0.3 & 33.3 & 3.3 \\
\hline $\mathrm{H}$ & EQUISYL & Equisetum sylvaticum & 0.0 & 0.0 & 1.0 & 0.3 & 0.3 & 33.3 & 3.3 \\
\hline $\mathrm{E}$ & USNEA\$\$\$ & Usnea spp. & 0.0 & 0.0 & 1.0 & 0.3 & 0.3 & 33.3 & 3.3 \\
\hline $\mathrm{S} 2$ & PICEGLA & Picea glauca & 0.0 & 0.0 & 1.0 & 0.3 & 0.3 & 33.3 & 3.3 \\
\hline $\mathrm{S} 1$ & PICEGLA & Picea glauca & 1.0 & 0.0 & 0.0 & 0.3 & 0.3 & 33.3 & 3.3 \\
\hline $\mathrm{Sl}$ & BETUOCC & Betula occidentalis & 1.0 & 0.0 & 0.0 & 0.3 & 0.3 & 33.3 & 3.3 \\
\hline M & POLYPIL & Polytrichum piliferum & 0.1 & 0.0 & 0.1 & 0.1 & 0.0 & 66.7 & 2.1 \\
\hline $\mathrm{H}$ & VICIAME & Vicia americana & 0.1 & 0.1 & 0.0 & 0.1 & 0.0 & 66.7 & 2.1 \\
\hline $\mathrm{H}$ & LATHOCH & Lathyrus ochroleucus & 0.1 & 0.1 & 0.0 & 0.1 & 0.0 & 66.7 & 2.1 \\
\hline S3 & AMELALN & Amelanchier alnifolia & 0.1 & 0.1 & 0.0 & 0.1 & 0.0 & 66.7 & 2.1 \\
\hline $\mathrm{H}$ & MELALIN & Medicago lupulina & 0.1 & 0.1 & 0.0 & 0.1 & 0.0 & 66.7 & 2.1 \\
\hline $\mathrm{L}$ & CLADONI & Cladonia spp. & 0.0 & 0.1 & 0.1 & 0.1 & 0.0 & 66.7 & 2.1 \\
\hline $\mathrm{H}$ & EQUIARV & Equisetum arvense & 0.1 & 0.0 & 0.1 & 0.1 & 0.0 & 66.7 & 2.1 \\
\hline S3 & PICEGLA & Picea glauca & 0.0 & 0.0 & 0.1 & 0.0 & 0.0 & 33.3 & 1.1 \\
\hline S3 & POPUTRE & Populus tremuloides & 0.0 & 0.0 & 0.1 & 0.0 & 0.0 & 33.3 & 1.1 \\
\hline S3 & PRUNPEN & Prunus pensylvanica & 0.1 & 0.0 & 0.0 & 0.0 & 0.0 & 33.3 & 1.1 \\
\hline G & POAINTE & Poa interior & 0.0 & 0.1 & 0.0 & 0.0 & 0.0 & 33.3 & 1.1 \\
\hline $\mathrm{S} 3$ & PINUBAN & Pinus banksiana & 0.0 & 0.0 & 0.1 & 0.0 & 0.0 & 33.3 & 1.1 \\
\hline M & MOSS\$\$ $\$$ & Unidentified Moss & 0.1 & 0.0 & 0.0 & 0.0 & 0.0 & 33.3 & 1.1 \\
\hline $\mathrm{H}$ & ACHIMIL & Achillea millefolium & 0.1 & 0.0 & 0.0 & 0.0 & 0.0 & 33.3 & 1.1 \\
\hline M & HYLOSPL & Hylocomium splendens & 0.1 & 0.0 & 0.0 & 0.0 & 0.0 & 33.3 & 1.1 \\
\hline M & PTILCRI & Ptilium crista-castrensis & 0.0 & 0.1 & 0.0 & 0.0 & 0.0 & 33.3 & 1.1 \\
\hline $\mathrm{H}$ & GEOCLIV & Geocaulon lividum & 0.1 & 0.0 & 0.0 & 0.0 & 0.0 & 33.3 & 1.1 \\
\hline $\mathrm{H}$ & LILIPHI & Lilium philadelphicum & 0.0 & 0.1 & 0.0 & 0.0 & 0.0 & 33.3 & 1.1 \\
\hline S2 & SHEPCAN & Shepherdia canadensis & 0.1 & 0.0 & 0.0 & 0.0 & 0.0 & 33.3 & 1.1 \\
\hline S2 & SALIBEB & Salix bebbiana & 0.1 & 0.0 & 0.0 & 0.0 & 0.0 & 33.3 & 1.1 \\
\hline G & AGROSCA & Agrostis scabra & 0.1 & 0.0 & 0.0 & 0.0 & 0.0 & 33.3 & 1.1 \\
\hline M & DICRPOL & Dicranum polysetum & 0.1 & 0.0 & 0.0 & 0.0 & 0.0 & 33.3 & 1.1 \\
\hline M & PYLAPOL & Pylaisiella polyantha & 0.0 & 0.0 & 0.1 & 0.0 & 0.0 & 33.3 & 1.1 \\
\hline S3 & RUBUPUB & Rubus pubescens & 0.1 & 0.0 & 0.0 & 0.0 & 0.0 & 33.3 & 1.1 \\
\hline $\mathrm{H}$ & GENTAMA & Gentianella amarella & 0.0 & 0.1 & 0.0 & 0.0 & 0.0 & 33.3 & 1.1 \\
\hline $\mathrm{H}$ & ARALNUD & Aralia nudicaulis & 0.0 & 0.1 & 0.0 & 0.0 & 0.0 & 33.3 & 1.1 \\
\hline
\end{tabular}


Table 27. Correlation table of plant community types with similarity ratings for the Populus tremuloides / Vaccinium myrtilloides / Arctostaphylos uva-ursi type.

\begin{tabular}{||l|c|l||}
\hline \multicolumn{1}{|c|}{ Similar Types } & $\begin{array}{c}\text { Similarity } \\
\text { Rating }\end{array}$ & \multicolumn{1}{c||}{ Comments } \\
\hline \hline $\begin{array}{l}\text { Pinus banksiana - Populus } \\
\text { tremuloides / Vaccinium myrtilloides } \\
\text { - Arctostaphylos } \text { uva-ursi CT (b1.1) } \\
\text { Beckingham and Archibald (1996) }\end{array}$ & $2(1)$ & $\begin{array}{l}\text { Very similar type but the current type tends to be more } \\
\text { open with less Pinus banksiana. }\end{array}$ \\
\hline $\begin{array}{l}\text { Populus tremuloides / Rosa spp. } \\
\text { Vaccinium spp. (Downing and } \\
\text { Karpuk 1992) }\end{array}$ & $1(2)$ & $\begin{array}{l}\text { This was a very similar community type that occurred in } \\
\text { the Low Boreal Mixedwood Ecoregion. Species } \\
\text { composition was quite similar although stands tend to be } \\
\text { more closed. }\end{array}$ \\
\hline $\begin{array}{l}\text { Populus tremuloides / Prunus } \\
\text { virginiana-Amelanchier / Carex } \\
\text { siccata CT (Coenen 2003) }\end{array}$ & 3 & $\begin{array}{l}\text { Some similarities with the current type in terms of } \\
\text { species composition but these are clearly different } \\
\text { communities. }\end{array}$ \\
\hline $\begin{array}{l}\text { Populus (tremuloides, balsamifera) - } \\
\text { (Betula papyrifera) - Picea mariana / } \\
\text { Alnus viridis Forest (CEGL002514) } \\
\text { (NatureServe 2004) }\end{array}$ & 3 & $\begin{array}{l}\text { This type may be similar but has more cover of Picea } \\
\text { mariana and Alnus viridis. Limited details were } \\
\text { available for this review. }\end{array}$ \\
\hline $\begin{array}{l}\text { Populus tremuloides - Betula } \\
\text { papyrifera / Abies balsamea, Picea } \\
\text { glauca) Forest (CEGL002466) } \\
\text { (NatureServe 2004) }\end{array}$ & 2 & $\begin{array}{l}\text { This community occupies similar site positions and has a } \\
\text { similar plant species composition. Differences include } \\
\text { the presence of several eastern species, lack of } \\
\text { Vaccinium vitis-idaea } \text { and Arctostaphylos } \text { uva-ursi, and } \\
\text { lower cover of Vaccinium myrtilloides. }\end{array}$ \\
\hline
\end{tabular}




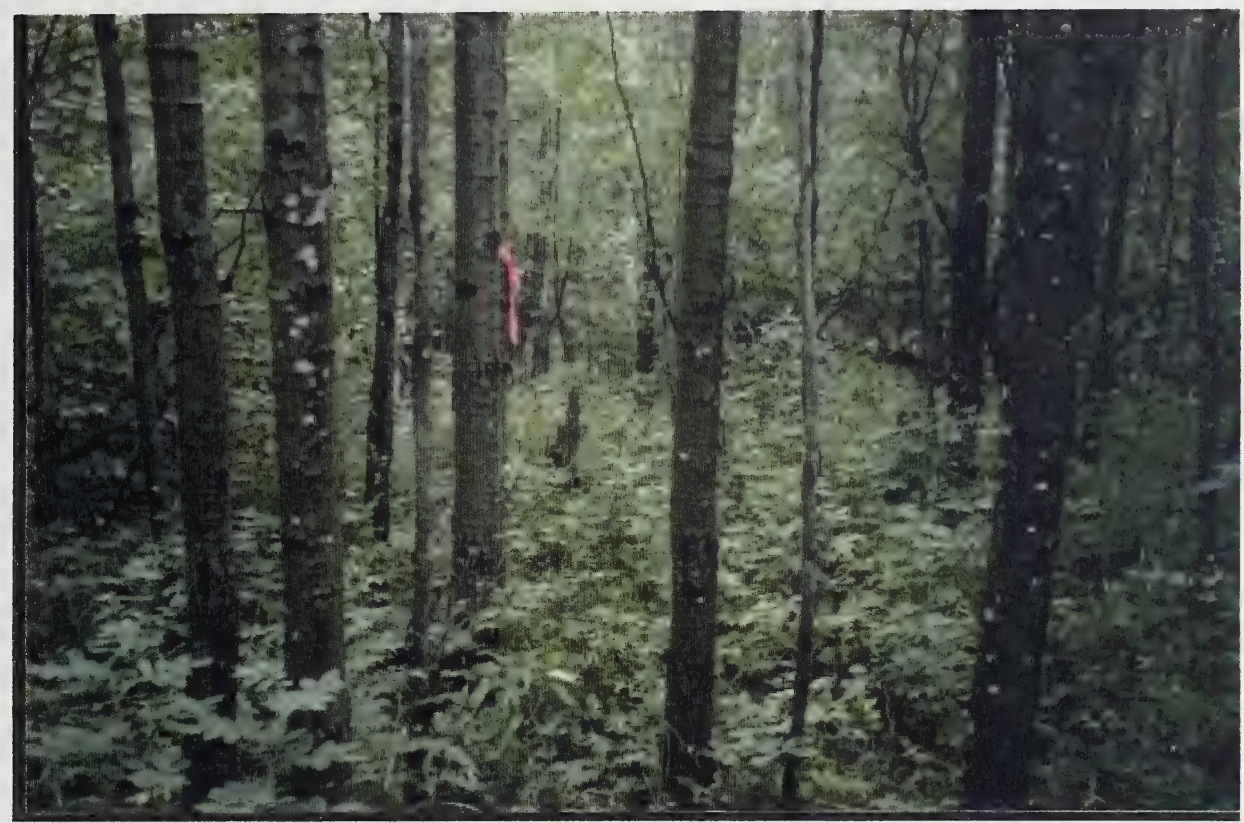

Plate 12. Populus tremuloides / Corylus cornuta Forest (P52).

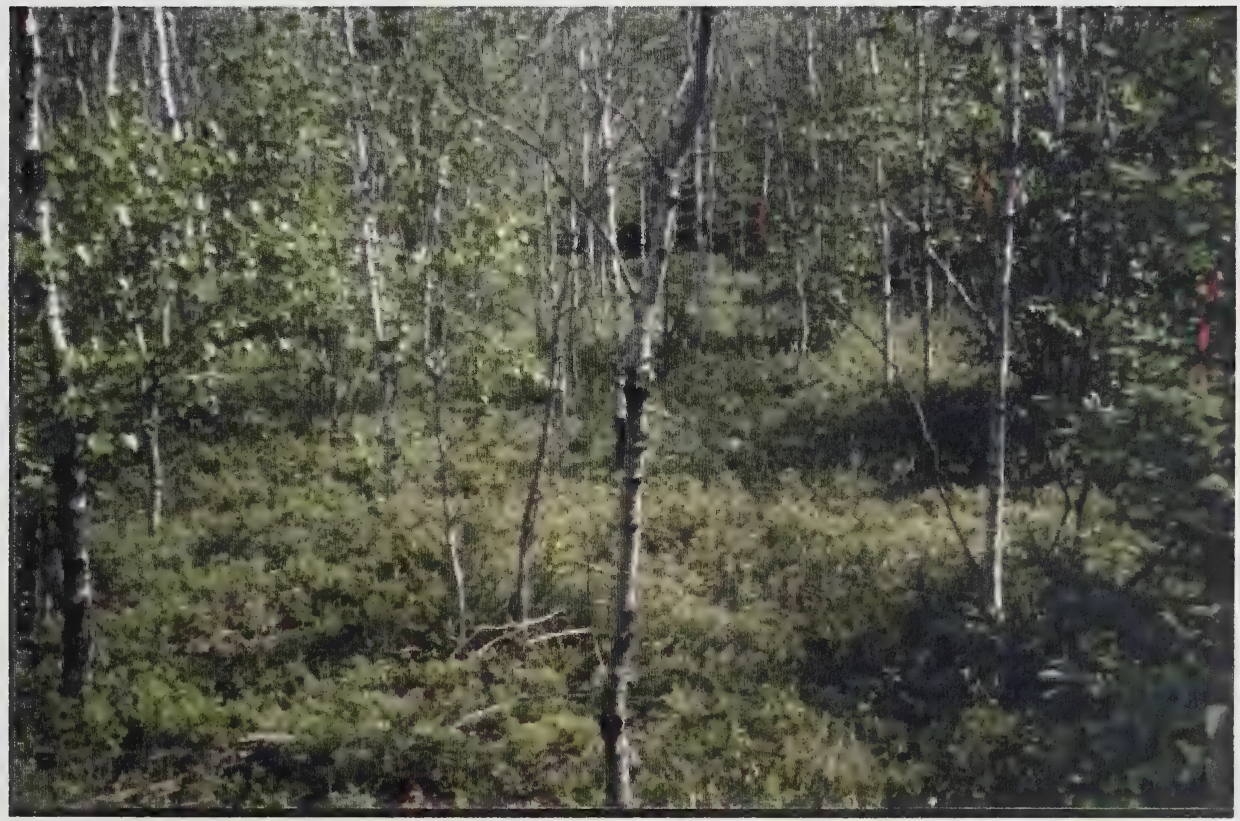

Plate 13. Populus tremuloides / Vaccinium myrtilloides / Arctostaphylos uva-ursi Forest (P64). 


\subsubsection{Populus tremuloides / Rosa acicularis / Aralia nudicaulis Forest Aspen / Prickly Rose / Sarsaparilla Forest}

This was a species rich mesic aspen forest that was expected to be common in the North Buck Lake study area and likely occurred at low incidence in the Holmes Crossing Sandhills Ecological Reserve. Sites may include level to lower receiving slope. At the three (3) plots completed, soils were well-drained and nutrient regimes were mesotrophic to permesotrophic. Surface substrate cover was dominated by organic matter (95\%) and decaying wood (5\%). Populus tremuloides formed pure closed canopy forests or sometimes with significant cover of Populus balsamifera that approached 15\% (Table 28). Other trees included scattered individuals or clumps of Betula papyrifera and Picea glauca. The shrub layer was relatively well developed and was dominated by Rosa acicularis (20\%), Amelanchier alnifolia (3\%), Cornus canadensis (3\%), Rubus idaeus (3\%), and Vaccinium myrtilloides (5\%). Other species in the shrub layer included Cornus stolonifera, Lonicera involucrata, Viburnum edule, Salix bebbiana, Picea glauca, Symphoricarpos occidentalis, and Linnaea borealis. Dominant forb cover consisted of Epilobium angustifolium (21\%), Aralia nudicaulis (11\%), Equisetum pratense (6\%), and Equisetum arvense (5\%). Other common herbs included Aster ciliolatus, Galium boreale, Mertensia paniculata, and Trientalis borealis. Graminoid cover was limited to Leymus innovatus (5\%), Calamagrostis canadensis (2\%), and trace amounts of Carex siccata, and Schizachne purpurascens.

Class: Forest

Subclass: Deciduous forest

Group: Cold-deciduous forest

Subgroup: Natural/Semi-natural cold-deciduous forest

Formation: Montane or boreal cold-deciduous forest

Alliance: Populus tremuloides Forest Alliance

Association: Populus tremuloides / Rosa acicularis / Aralia nudicaulis Forest

Unique Identifier: $\mathrm{n} / \mathrm{a}$

Classification Confidence Level: 2 (Moderate) There was relatively good consistency between plots and similar types have been reported in the literature. Geographical range was uncertain.

Dominant Species: Populus tremuloides, Rosa acicularis, Cornus canadensis, Aralia nudicaulis, Epilobium angustifolium, Equisetum pratense, Equisetum arvense, Leymus innovatus Co-Dominant Species: Populus balsamifera, Betula papyrifera, Cornus stolonifera, Lonicera involucrata, Rubus idaeus, Viburnum edule, Salix bebbiana, Vaccinium myrtilloides, Linnaea borealis Equisetum sylvaticum, Fragaria virginiana, Galium boreale, Lathyrus ochroleucus, Maianthemum canadense, Trientalis borealis, Calamagrostis canadensis

Diagnostic Species: Populus tremuloides, Rosa acicularis, Cornus canadensis, Linnaea borealis, Aralia nudicaulis, Aster ciliolatus, Epilobium angustifolium, Equisetum pratense, Equisetum arvense, Equisetum sylvaticum, Galium boreale, Mertensia paniculata, Trientalis borealis, Calamagrostis canadensis, Leymus innovatus

\section{Literature Review:}

Allen et al. (2002) noted the occurrence of a Populus tremuloides / Viburnum edule - Rosa acicularis community type from the La Butte Creek Wildland Provincial Park located north of Lake Athabasca. This was a common type in the Park occurring on level mesic to submesic sites. It had a diverse shrub layer that may include significant cover of Shepherdia canadensis and some Picea glauca.

Environmental Management Associates (1993) described a Populus tremuloides - (P. balsamifera) / Rosa acicularis - (Rubus idaeus) vegetation type that was common in the Lower Boreal Cordilleran Ecoregion. It typically occurred on mesic well-drained sites with clay loam to silty clay loam soils. Plant species composition was quite similar to the current classification although there was significantly more Populus 
Table 28. Summary of plot data and descriptive statistics for the Populus tremuloides / Rosa acicularis / Aralia nudicaulis community type $(\mathrm{n}=3)$.

\begin{tabular}{|c|c|c|c|c|c|c|c|c|c|}
\hline \multirow[b]{2}{*}{ Strata } & \multirow[b]{2}{*}{ Code } & \multirow[b]{2}{*}{ Species } & \multicolumn{3}{|c|}{ Plots } & \multirow[b]{2}{*}{ Mean } & \multirow[b]{2}{*}{ SE } & \multirow[b]{2}{*}{ Constancy } & \multirow[b]{2}{*}{ Prominence } \\
\hline & & & P09 & P34 & P54 & & & & \\
\hline $\mathrm{T} 1$ & POPUTRE & Populus tremuloides & 70.0 & 60.0 & 40.0 & 56.7 & 8.8 & 100.0 & 75.3 \\
\hline $\mathrm{H}$ & EPILANG & Epilobium angustifolium & 3.0 & 60.0 & 0.1 & 21.0 & 19.5 & 100.0 & 45.9 \\
\hline S2 & ROSAACI & Rosa acicularis & 20.0 & 25.0 & 15.0 & 20.0 & 2.9 & 100.0 & 44.7 \\
\hline $\mathrm{H}$ & ARALNUD & Aralia nudicaulis & 10.0 & 8.0 & 15.0 & 11.0 & 2.1 & 100.0 & 33.2 \\
\hline G & ELYMINN & Leymus innovatus & 1.0 & 15.0 & 0.1 & 5.4 & 4.8 & 100.0 & 23.2 \\
\hline $\mathrm{H}$ & EQUIARV & Equisetum arvense & 1.0 & 3.0 & 10.0 & 4.7 & 2.7 & 100.0 & 21.6 \\
\hline $\mathrm{H}$ & EQUIPRA & Equisetum pratense & 0.0 & 15.0 & 4.0 & 6.3 & 4.5 & 66.7 & 20.5 \\
\hline S2 & AMELALN & Amelanchier alnifolia & 10.0 & 0.1 & 0.0 & 3.4 & 3.3 & 66.7 & 15.0 \\
\hline S3 & CORNCAN & Cornus canadensis & 0.0 & 8.0 & 2.0 & 3.3 & 2.4 & 66.7 & 14.9 \\
\hline S3 & LINNBOR & Linnaea borealis & 0.1 & 5.0 & 0.1 & 1.7 & 1.6 & 100.0 & 13.2 \\
\hline $\mathrm{T} 1$ & POPUBAL & Populus balsamifera & 0.0 & 0.0 & 15.0 & 5.0 & 5.0 & 33.3 & 12.9 \\
\hline $\mathrm{H}$ & MAIACAN & Maianthemum canadense & 2.0 & 2.0 & 0.1 & 1.4 & 0.6 & 100.0 & 11.7 \\
\hline G & CALACAN & Calamagrostis canadensis & 0.0 & 5.0 & 0.1 & 1.7 & 1.7 & 66.7 & 10.6 \\
\hline $\mathrm{H}$ & LATHOCH & Lathyrus ochroleucus & 2.0 & 3.0 & 0.0 & 1.7 & 0.9 & 66.7 & 10.5 \\
\hline S2 & RUBUIDA & Rubus idaeus & 0.0 & 10.0 & 0.0 & 3.3 & 3.3 & 33.3 & 10.5 \\
\hline S3 & VACCMYR & Vaccinium myrtilloides & 0.0 & 9.0 & 0.0 & 3.0 & 3.0 & 33.3 & 10.0 \\
\hline S2 & CORNSTO & Cornus stolonifera & 0.0 & 0.1 & 4.0 & 1.4 & 1.3 & 66.7 & 9.5 \\
\hline $\mathrm{H}$ & FRAGVIR & Fragaria virginiana & 0.0 & 3.0 & 0.1 & 1.0 & 1.0 & 66.7 & 8.3 \\
\hline S3 & ROSAACI & Rosa acicularis & 0.0 & 0.0 & 6.0 & 2.0 & 2.0 & 33.3 & 8.2 \\
\hline S2 & LONIINV & Lonicera involucrata & 0.0 & 0.0 & 6.0 & 2.0 & 2.0 & 33.3 & 8.2 \\
\hline S3 & CORNSTO & Cornus stolonifera & 0.0 & 0.0 & 5.0 & 1.7 & 1.7 & 33.3 & 7.5 \\
\hline S3 & VIBUEDU & Viburnum edule & 0.0 & 0.0 & 5.0 & 1.7 & 1.7 & 33.3 & 7.5 \\
\hline S2 & PRUNPEN & Prunus pensylvanica & 4.0 & 0.0 & 0.0 & 1.3 & 1.3 & 33.3 & 6.7 \\
\hline S3 & LONIINV & Lonicera involucrata & 0.0 & 0.0 & 4.0 & 1.3 & 1.3 & 33.3 & 6.7 \\
\hline $\mathrm{T} 1$ & BETUPAP & Betula papyrifera & 0.0 & 0.0 & 4.0 & 1.3 & 1.3 & 33.3 & 6.7 \\
\hline $\mathrm{H}$ & GALIBOR & Galium boreale & 0.1 & 1.0 & 0.1 & 0.4 & 0.3 & 100.0 & 6.3 \\
\hline $\mathrm{S} 2$ & PRUNVIR & Prunus virginiana & 3.0 & 0.0 & 0.0 & 1.0 & 1.0 & 33.3 & 5.8 \\
\hline $\mathrm{H}$ & RUBUPUB & Rubus pubescens & 0.1 & 0.0 & 1.0 & 0.4 & 0.3 & 66.7 & 4.9 \\
\hline S3 & RUBUIDA & Rubus idaeus & 1.0 & 0.0 & 0.1 & 0.4 & 0.3 & 66.7 & 4.9 \\
\hline $\mathrm{H}$ & EQUISYL & Equisetum sylvaticum & 0.0 & 1.0 & 0.1 & 0.4 & 0.3 & 66.7 & 4.9 \\
\hline S3 & SYMPOCC & Symphoricarpos occidentalis & 1.0 & 0.1 & 0.0 & 0.4 & 0.3 & 66.7 & 4.9 \\
\hline $\mathrm{H}$ & TRIEBOR & Trientalis borealis & 0.0 & 0.1 & 1.0 & 0.4 & 0.3 & 66.7 & 4.9 \\
\hline $\mathrm{H}$ & CAMPROT & Campanula rotundifolia & 0.1 & 1.0 & 0.0 & 0.4 & 0.3 & 66.7 & 4.9 \\
\hline S2 & SALIBEB & Salix bebbiana & 0.0 & 2.0 & 0.0 & 0.7 & 0.7 & 33.3 & 4.7 \\
\hline S3 & SALIBEB & Salix bebbiana & 0.0 & 2.0 & 0.0 & 0.7 & 0.7 & 33.3 & 4.7 \\
\hline S2 & VIBUEDU & Viburnum edule & 0.0 & 0.0 & 1.0 & 0.3 & 0.3 & 33.3 & 3.3 \\
\hline G & SCHIPUR & Schizachne purpurascens & 1.0 & 0.0 & 0.0 & 0.3 & 0.3 & 33.3 & 3.3 \\
\hline S3 & POPUTRE & Populus tremuloides & 0.0 & 1.0 & 0.0 & 0.3 & 0.3 & 33.3 & 3.3 \\
\hline $\mathrm{H}$ & SMILSTE & Smilacina stellata & 1.0 & 0.0 & 0.0 & 0.3 & 0.3 & 33.3 & 3.3 \\
\hline $\mathrm{H}$ & ASTECON & Aster conspicuus & 0.0 & 1.0 & 0.0 & 0.3 & 0.3 & 33.3 & 3.3 \\
\hline S1 & VIBUEDU & Viburnum edule & 0.0 & 0.0 & 1.0 & 0.3 & 0.3 & 33.3 & 3.3 \\
\hline $\mathrm{H}$ & VICIAME & Vicia americana & 0.1 & 0.1 & 0.0 & 0.1 & 0.0 & 66.7 & 2.1 \\
\hline $\mathrm{H}$ & ASTECIL & Aster ciliolatus & 0.0 & 0.1 & 0.1 & 0.1 & 0.0 & 66.7 & 2.1 \\
\hline S3 & VACCVIT & Vaccinium vitis-idaea & 0.1 & 0.1 & 0.0 & 0.1 & 0.0 & 66.7 & 2.1 \\
\hline G & CARESIC & Carex siccata & 0.1 & 0.0 & 0.1 & 0.1 & 0.0 & 66.7 & 2.1 \\
\hline $\mathrm{H}$ & MERTPAN & Mertensia paniculata & 0.0 & 0.1 & 0.1 & 0.1 & 0.0 & 66.7 & 2.1 \\
\hline $\mathrm{H}$ & VIOLREN & Viola renifolia & 0.0 & 0.0 & 0.1 & 0.0 & 0.0 & 33.3 & 1.1 \\
\hline
\end{tabular}


Table 28. (Continued)

\begin{tabular}{|c|c|c|c|c|c|c|c|c|c|}
\hline \multirow[b]{2}{*}{ Strata } & \multirow[b]{2}{*}{ Code } & \multirow[b]{2}{*}{ Species } & \multicolumn{3}{|c|}{ Plots } & \multirow[b]{2}{*}{ Mean } & \multirow[b]{2}{*}{ SE } & \multirow[b]{2}{*}{ Constancy } & \multirow[b]{2}{*}{ Prominence } \\
\hline & & & P09 & P34 & P54 & & & & \\
\hline $\mathrm{H}$ & VIOLADU & Viola adunca & 0.1 & 0.0 & 0.0 & 0.0 & 0.0 & 33.3 & 1.1 \\
\hline M & HYLOSPL & Hylocomium splendens & 0.0 & 0.0 & 0.1 & 0.0 & 0.0 & 33.3 & 1.1 \\
\hline $\mathrm{H}$ & PYROCHL & Pyrola chlorantha & 0.1 & 0.0 & 0.0 & 0.0 & 0.0 & 33.3 & 1.1 \\
\hline M & MOSS\$\$ $\$$ & Moss spp. & 0.0 & 0.1 & 0.0 & 0.0 & 0.0 & 33.3 & 1.1 \\
\hline $\mathrm{H}$ & THALVEN & Thalictrum venulosum & 0.1 & 0.0 & 0.0 & 0.0 & 0.0 & 33.3 & 1.1 \\
\hline M & MOSSES\$\$ & Moss spp. & 0.0 & 0.0 & 0.1 & 0.0 & 0.0 & 33.3 & 1.1 \\
\hline M & PLEUSCH & Pleurozium schreberi & 0.0 & 0.0 & 0.1 & 0.0 & 0.0 & 33.3 & 1.1 \\
\hline M & PTILCRI & Ptilium crista-castrensis & 0.1 & 0.0 & 0.0 & 0.0 & 0.0 & 33.3 & 1.1 \\
\hline $\mathrm{H}$ & PETAPAL & Petasites frigidus var palmatus & 0.0 & 0.0 & 0.1 & 0.0 & 0.0 & 33.3 & 1.1 \\
\hline M & BRACSAL & Brachythecium salebrosum & 0.1 & 0.0 & 0.0 & 0.0 & 0.0 & 33.3 & 1.1 \\
\hline G & JUNCBAL & Juncus balticus & 0.1 & 0.0 & 0.0 & 0.0 & 0.0 & 33.3 & 1.1 \\
\hline $\mathrm{H}$ & MITENUD & Mitella nuda & 0.0 & 0.0 & 0.1 & 0.0 & 0.0 & 33.3 & 1.1 \\
\hline $\mathrm{S} 1$ & ALNUVIR & Alnus viridis & 0.1 & 0.0 & 0.0 & 0.0 & 0.0 & 33.3 & 1.1 \\
\hline $\mathrm{H}$ & ACHIMIL & Achillea millefolium & 0.0 & 0.1 & 0.0 & 0.0 & 0.0 & 33.3 & 1.1 \\
\hline S3 & LONIDIO & Lonicera dioica & 0.1 & 0.0 & 0.0 & 0.0 & 0.0 & 33.3 & 1.1 \\
\hline $\mathrm{H}$ & ASTELAE & Aster laevis & 0.1 & 0.0 & 0.0 & 0.0 & 0.0 & 33.3 & 1.1 \\
\hline $\mathrm{H}$ & GALITRF & Galium triflorum & 0.0 & 0.0 & 0.1 & 0.0 & 0.0 & 33.3 & 1.1 \\
\hline S1 & AMELALN & Amelanchier alnifolia & 0.0 & 0.0 & 0.1 & 0.0 & 0.0 & 33.3 & 1.1 \\
\hline S3 & ARCTUVA & Arctostaphylos uva-ursi & 0.0 & 0.1 & 0.0 & 0.0 & 0.0 & 33.3 & 1.1 \\
\hline S3 & RIBETRI & Ribes triste & 0.0 & 0.0 & 0.1 & 0.0 & 0.0 & 33.3 & 1.1 \\
\hline $\mathrm{H}$ & LILIPHI & Lilium philadelphicum & 0.0 & 0.1 & 0.0 & 0.0 & 0.0 & 33.3 & 1.1 \\
\hline $\mathrm{H}$ & EQUILAE & Equisetum laevigatum & 0.1 & 0.0 & 0.0 & 0.0 & 0.0 & 33.3 & 1.1 \\
\hline $\mathrm{S} 2$ & PICEGLA & Picea glauca & 0.0 & 0.1 & 0.0 & 0.0 & 0.0 & 33.3 & 1.1 \\
\hline $\mathrm{H}$ & ACTARUB & Actaea rubra & 0.0 & 0.0 & 0.1 & 0.0 & 0.0 & 33.3 & 1.1 \\
\hline S1 & SALIBEB & Salix bebbiana & 0.0 & 0.0 & 0.1 & 0.0 & 0.0 & 33.3 & 1.1 \\
\hline
\end{tabular}

tremuloides regeneration and Calamagrostis canadensis cover. Aralia nudicaulis cover was considerably less than that reported for the current classification.

Beckingham and Archibald (1996) identified a Populus tremuloides / Rosa acicularis / Aralia nudicaulis plant community (d1.6) in the boreal mixedwood. This community type was very similar to the current classification and all diagnostic species were recorded in the North Buck Lake plots. Picea glauca was not found in the overstorey of the current plots but this species was observed in the understorey and stands succeed to Picea glauca.

NatureServe (2004) lists a Populus tremuloides - Betula papyrifera / (Abies balsamea, Picea glauca) Forest (CEGL002466). This community occurred in the boreal ecoregions of Minnesota, Michigan, Ontario, and Manitoba. Characteristic sites include ridgetops and gentle to moderate upper, mid, and lower slopes. Soils were well-drained to rapidly drained mineral soils with dry to mesic moisture levels. The canopy layer was dominated by Populus tremuloides, Betula papyrifera and Populus grandidentata may be present. Conifer cover was usually less than $25 \%$ and consisted of Abies balsamea and Picea glauca. Common shrubs include Acer spicatum, Corylus cornuta, Diervilla lonicera, Linnaea borealis, Lonicera canadensis, Rosa acicularis, Rubus pubescens, Sorbus decora, and Vaccinium myrtilloides. The dominant species in the herb layer was Eurybia macrophylla (= Aster macrophyllus). Other common forbs include Anemone quinquefolia, Aralia nudicaulis, Clintonia borealis, Cornus canadensis, Galium triflorum, Maianthemum canadense, Mitella nuda, Pteridium aquilinum, Streptopus roseus, Trientalis borealis, and Viola renifolia. Important mosses were Plagiomnium cuspidatum, Pleurozium schreberi, Ptilium crista-castrensis, and Rhytidiadelphus triquetrus. 
NatureServe (2004) lists Picea mariana - Populus tremuloides / Mixed Herbs Forest (CEGL002516) that was ranked G4G5. This type was found in the boreal regions of the upper midwestern United States and across central Canada from Manitoba (Sims et al. 1989, Zoladeski et al. 1995) to possibly Quebec. It occurred on flat to gently sloping sites with mesic to moist soils that were coarse loam, but can be clay, silt, or sand. The overstorey has a closed canopy of Populus tremuloides and Picea mariana with scattered Betula papyrifera, Populus balsamifera, Abies balsamea, Picea glauca, and Pinus banksiana. Shrub layer cover was variable and included Diervilla lonicera, Ledum groenlandicum, Linnaea borealis, Rosa acicularis, Rubus pubescens, Vaccinium angustifolium, and Vaccinium myrtilloides. The herbaceous layer was diverse and common species include Aralia nudicaulis, Eurybia macrophylla (= Aster macrophyllus), Cornus canadensis, Coptis trifolia, Maianthemum canadense, Petasites frigidus, Trientalis borealis, and Viola renifolia. Mosses were also common. Similarity ratings for related plant community types are provided in Table 29.

Table 29. Correlation table of plant community types with similarity ratings for the Populus tremuloides / Rosa acicularis / Aralia nudicaulis type.

\begin{tabular}{||l|c|l||}
\hline \multicolumn{1}{|c|}{ Similar Types } & $\begin{array}{c}\text { Similarity } \\
\text { Rating }\end{array}$ & \multicolumn{1}{|c||}{ Comments } \\
\hline \hline $\begin{array}{l}\text { Populus tremuloides / Viburnum } \\
\text { edule - Rosa acicularis CT (Allen } \text { et } \\
\text { al. 2002) }\end{array}$ & $(2) 3$ & $\begin{array}{l}\text { A related type that may be drier. Few details were } \\
\text { available regarding plant community composition. }\end{array}$ \\
\hline $\begin{array}{l}\text { Populus tremuloides - (P. } \\
\text { balsamifera) / Rosa acicularis - } \\
\text { (Rubus idaeus) (Environmental } \\
\text { Management Associates 1993) }\end{array}$ & $2(1)$ & $\begin{array}{l}\text { A very similar type reported from the Low Boreal } \\
\text { Cordilleran Ecoregion. Differences in species } \\
\text { composition and dominance can likely be attributed } \\
\text { mainly to the finer textured soils in that study. }\end{array}$ \\
\hline $\begin{array}{l}\text { Populus tremuloides / Rosa } \\
\text { acicularis / Aralia nudicaulis CT } \\
\text { (d1.6) (Beckingham and Archibald } \\
\text { 1996) }\end{array}$ & 1 & $\begin{array}{l}\text { Very good fit of this type with the current classification } \\
\text { in terms of ecological niche and floristics. }\end{array}$ \\
\hline $\begin{array}{l}\text { Populus tremuloides - Betula } \\
\text { papyrifera / (Abies balsamea, Picea } \\
\text { glauca) Forest (CEGL002466) } \\
\text { (NatureServe 2004) }\end{array}$ & 3 & $\begin{array}{l}\text { Similar type but sites may be somewhat drier and have } \\
\text { poorer nutrient availability. This type included some } \\
\text { eastern species. }\end{array}$ \\
\hline $\begin{array}{l}\text { Picea mariana } \text { - Populus tremuloides } \\
\text { / Mixed Herbs Forest (CEGL002516) } \\
\text { (NatureServe 2004) }\end{array}$ & 3 & $\begin{array}{l}\text { Picea mariana } \text { was dominant in the overstorey in this } \\
\text { type. The understorey has some similarities in species } \\
\text { composition but included eastern species. }\end{array}$ \\
\hline
\end{tabular}

\subsubsection{Populus tremuloides / Alnus viridis / Aralia nudicaulis Forest Aspen / Green Alder / Sarsaparilla Forest}

This was a common community type in the two study areas and a total of five plots were completed including four (4) in Holmes Crossing Sandhills Ecological Reserve and one (1) in the North Buck Lake study area (Table 30). It occurred on mid-slope receiving positions and less frequently on level sites. Slope gradients average $8 \%$ and ranged between $3 \%$ and $12 \%$. Aspects were variable although northerly and easterly aspects predominated. Soils were well drained with mesic moisture levels and mesotrophic to permesotrophic nutrient regimes. Surface substrate cover consisted mainly of organic matter (96\%) and decaying wood (4\%). This community type had the highest species diversity of all the communities sampled. It was recognised by the closed canopy of Populus tremuloides, typically $6 \%$ to $20 \%$ cover of Alnus viridis (mean of 16\%), and high constancy of Aralia nudicaulis occurring at a mean percent cover of 
$11 \%$ (range $4 \%$ to $30 \%$ ). Other important species included Vaccinium myrtilloides, Prunus pensylvanica, Rosa acicularis, Vaccinium vitis-idaea, Rubus idaeus, Cornus canadensis, Epilobium angustifolium, Maianthemum canadense, and Linnaea borealis. These stands will succeed to climax Picea glauca forest in the absence of wildfires. Remnant Pinus banksiana veterans may be present, as was the case with plot $\# 18$.

Class: Forest

Subclass: Deciduous forest

Group: Cold-deciduous forest

Subgroup: Natural/Semi-natural cold-deciduous forest

Formation: Montane or boreal cold-deciduous forest

Alliance: Populus tremuloides Forest Alliance

Association: Populus tremuloides / Alnus viridis / Aralia nudicaulis Forest

Unique Identifier: $\mathrm{n} / \mathrm{a}$

Classification Confidence Level: 1 (Strong) Distinctive type that was common in the study areas and was well documented in the literature. Was a wide spread community type but geographical range was uncertain.

Dominant Species: Populus tremuloides, Alnus viridis, Cornus canadensis, Vaccinium myrtilloides, Aralia nudicaulis

Co-Dominant Species: Picea glauca, Prunus pensylvanica, Rosa acicularis, Vaccinium vitis-idaea, Epilobium angustifolium, Maianthemum canadense

Diagnostic Species: Populus tremuloides, Alnus viridis, Cornus canadensis, Linnaea borealis, Rubus idaeus, Vaccinium myrtilloides, Vaccinium vitis-idaea, Aralia nudicaulis, Epilobium angustifolium

\section{Literature Review:}

Nelson et al. (1989) completed five (5) plots in a Populus tremuloides / Alnus viridis / Aralia nudicaulis community occurring in the Holmes Crossing proposed Natural Area. It was found on level to rolling sand plains. Soil textures were sand and loamy sand, and soils were classified as Orthic Eutric Brunisols. Sites were well to rapidly drained with a subxeric to submesic moisture regimes. Species composition was very similar between this type and the current classification.

Allen et al. (2002) noted the occurrence of a Populus tremuloides / Alnus crispa Community Type from the La Butte Creek Wildland Provincial Park located north of Lake Athabasca. Alnus crispa formed a dense shrub layer and few other species were recorded in the understorey.

Environmental Management Associates (1993) described a Populus tremuloides - (P. balsamifera) / Alnus viridis / Aralia nudicaulis that was common in the Lower Boreal Cordilleran Ecoregion. This type occurred on similar sites that had sandy clay loam soils. The plant species composition of this community was very similar to the current classification although Calamagrostis canadensis has greater cover values and was listed as a dominant species.

Beckingham and Archibald (1996) described a Populus tremuloides / Alnus crispa type (d1.4) occurring in the boreal mixedwood. This community appears to be similar to the current classification although Populus balsamifera was not present and there was no Viburnum edule in the shrub layer. In addition Linnaea borealis, Rubus pubescens, and Calamagrostis canadensis cover was lower in the current type. Other similar types described by Beckingham and Archibald (1996) include the Populus tremuloides Picea glauca / Alnus crispa type (d2.3) and the Picea glauca / Alnus crispa (d3.2) community type. These were less similar to the current classification based on dominance of spruce in the overstorey and greater species divergence in the understorey and moss layers. 
Table 30. Summary of plot data and descriptive statistics for the Populus tremuloides / Alnus viridis / Aralia nudicaulis community type $(\mathrm{n}=5)$.

\begin{tabular}{|c|c|c|c|c|c|c|c|c|c|c|c|}
\hline \multirow[b]{2}{*}{ Strata } & \multirow[b]{2}{*}{ Code } & \multirow[b]{2}{*}{ Species } & \multicolumn{5}{|c|}{ Plots } & \multirow[b]{2}{*}{ Mean } & \multirow[b]{2}{*}{ SE } & \multirow[b]{2}{*}{ Constancy } & \multirow[b]{2}{*}{ Prominence } \\
\hline & & & P03 & P17 & P18 & $\mathbf{P 2 3}$ & P50 & & & & \\
\hline $\mathrm{T} 1$ & POPUTRE & Populus tremuloides & 60.0 & 60.0 & 0.0 & 80.0 & 70.0 & 54.0 & 14.0 & 80.0 & 65.7 \\
\hline S1 & ALNUVIR & Alnus viridis & 15.0 & 6.0 & 20.0 & 20.0 & 20.0 & 16.2 & 2.7 & 100.0 & 40.2 \\
\hline S3 & VACCMYR & Vaccinium myrtilloides & 25.0 & 8.0 & 5.0 & 10.0 & 15.0 & 12.6 & 3.5 & 100.0 & 35.5 \\
\hline $\mathrm{H}$ & ARALNUD & Aralia nudicaulis & 4.0 & 10.0 & 6.0 & 30.0 & 4.0 & 10.8 & 4.9 & 100.0 & 32.9 \\
\hline S3 & CORNCAN & Cornus canadensis & 30.0 & 11.0 & 4.0 & 0.1 & 2.0 & 9.4 & 5.5 & 100.0 & 30.7 \\
\hline $\mathrm{T} 2$ & POPUTRE & Populus tremuloides & 0.0 & 3.0 & 60.0 & 0.0 & 0.0 & 12.6 & 11.9 & 40.0 & 22.4 \\
\hline S3 & ROSAACI & Rosa acicularis & 15.0 & 6.0 & 4.0 & 3.0 & 0.0 & 5.6 & 2.5 & 80.0 & 21.2 \\
\hline S3 & VACCVIT & Vaccinium vitis-idaea & 2.0 & 0.1 & 20.0 & 0.1 & 0.1 & 4.5 & 3.9 & 100.0 & 21.1 \\
\hline T2 & PICEGLA & Picea glauca & 4.0 & 30.0 & 1.0 & 0.0 & 0.0 & 7.0 & 5.8 & 60.0 & 20.5 \\
\hline S1 & PRUNPEN & Prunus pensylvanica & 1.0 & 2.0 & 0.0 & 3.0 & 4.0 & 2.0 & 0.7 & 80.0 & 12.6 \\
\hline $\mathrm{H}$ & MAIACAN & Maianthemum canadense & 0.1 & 1.0 & 4.0 & 3.0 & 0.0 & 1.6 & 0.8 & 80.0 & 11.4 \\
\hline S2 & ROSAACI & Rosa acicularis & 0.0 & 0.1 & 0.0 & 0.0 & 10.0 & 2.0 & 2.0 & 40.0 & 9.0 \\
\hline $\mathrm{E}$ & EPIPHYT & Epiphyte spp. & 0.0 & 0.0 & 1.0 & 0.0 & 6.0 & 1.4 & 1.2 & 40.0 & 7.5 \\
\hline E & USNEA\$\$\$ & Usnea spp. & 1.0 & 5.0 & 0.0 & 0.0 & 0.0 & 1.2 & 1.0 & 40.0 & 6.9 \\
\hline $\mathrm{H}$ & EPILANG & Epilobium angustifolium & 2.0 & 0.1 & 0.1 & 0.1 & 0.1 & 0.5 & 0.4 & 100.0 & 6.9 \\
\hline S3 & LINNBOR & Linnaea borealis & 1.0 & 0.1 & 1.0 & 0.1 & 0.1 & 0.5 & 0.2 & 100.0 & 6.8 \\
\hline S3 & RUBUIDA & Rubus idaeus & 1.0 & 0.1 & 0.1 & 0.1 & 1.0 & 0.5 & 0.2 & 100.0 & 6.8 \\
\hline $\mathrm{H}$ & LYCOCOM & Diphasiastrum complanatum & 0.0 & 0.0 & 3.0 & 1.0 & 0.0 & 0.8 & 0.6 & 40.0 & 5.7 \\
\hline $\mathrm{T} 1$ & PICEGLA & Picea glauca & 1.0 & 3.0 & 0.0 & 0.0 & 0.0 & 0.8 & 0.6 & 40.0 & 5.7 \\
\hline $\mathrm{H}$ & GALIBOR & Galium boreale & 1.0 & 0.1 & 0.1 & 0.1 & 0.1 & 0.3 & 0.2 & 100.0 & 5.3 \\
\hline $\mathrm{T} 2$ & BETUPAP & Betula papyrifera & 0.0 & 1.0 & 0.0 & 0.0 & 2.0 & 0.6 & 0.4 & 40.0 & 4.9 \\
\hline $\mathrm{Tl}$ & PINUBAN & Pinus banksiana & 0.0 & 0.0 & 5.0 & 0.0 & 0.0 & 1.0 & 1.0 & 20.0 & 4.5 \\
\hline S1 & SALIBEB & Salix bebbiana & 0.0 & 0.0 & 0.0 & 0.1 & 2.0 & 0.4 & 0.4 & 40.0 & 4.1 \\
\hline S3 & ARCTUVA & Arctostaphylos uva-ursi & 0.0 & 0.0 & 4.0 & 0.0 & 0.0 & 0.8 & 0.8 & 20.0 & 4.0 \\
\hline $\mathrm{H}$ & VIOLREN & Viola renifolia & 1.0 & 0.1 & 0.0 & 0.1 & 0.0 & 0.2 & 0.2 & 60.0 & 3.8 \\
\hline $\mathrm{H}$ & FRAGVIR & Fragaria virginiana & 1.0 & 0.1 & 0.1 & 0.0 & 0.0 & 0.2 & 0.2 & 60.0 & 3.8 \\
\hline $\mathrm{H}$ & LYCODEN & Lycopodium dendroideum & 3.0 & 0.0 & 0.0 & 0.0 & 0.0 & 0.6 & 0.6 & 20.0 & 3.5 \\
\hline S2 & PICEGLA & Picea glauca & 0.1 & 0.0 & 1.0 & 0.0 & 0.0 & 0.2 & 0.2 & 40.0 & 3.0 \\
\hline $\mathrm{H}$ & ASTECIL & Aster ciliolatus & 1.0 & 0.0 & 0.0 & 0.0 & 0.1 & 0.2 & 0.2 & 40.0 & 3.0 \\
\hline $\mathrm{H}$ & PYROASA & Pyrola asarifolia & 0.0 & 0.0 & 0.0 & 2.0 & 0.0 & 0.4 & 0.4 & 20.0 & 2.8 \\
\hline M & PLEUSCH & Pleurozium schreberi & 2.0 & 0.0 & 0.0 & 0.0 & 0.0 & 0.4 & 0.4 & 20.0 & 2.8 \\
\hline $\mathrm{T} 1$ & BETUPAP & Betula papyrifera & 0.0 & 2.0 & 0.0 & 0.0 & 0.0 & 0.4 & 0.4 & 20.0 & 2.8 \\
\hline S3 & LONIINV & Lonicera involucrata & 2.0 & 0.0 & 0.0 & 0.0 & 0.0 & 0.4 & 0.4 & 20.0 & 2.8 \\
\hline S3 & VIBUEDU & Viburnum edule & 0.0 & 0.0 & 0.0 & 0.0 & 2.0 & 0.4 & 0.4 & 20.0 & 2.8 \\
\hline $\mathrm{H}$ & EQUIARV & Equisetum arvense & 0.1 & 0.1 & 0.1 & 0.0 & 0.1 & 0.1 & 0.0 & 80.0 & 2.5 \\
\hline M & HYLOSPL & Hylocomium splendens & 0.1 & 0.1 & 0.0 & 0.1 & 0.1 & 0.1 & 0.0 & 80.0 & 2.5 \\
\hline G & ELYMINN & Leymus innovatus & 0.1 & 0.1 & 0.1 & 0.1 & 0.0 & 0.1 & 0.0 & 80.0 & 2.5 \\
\hline $\mathrm{H}$ & ACHIMIL & Achillea millefolium & 1.0 & 0.0 & 0.0 & 0.0 & 0.0 & 0.2 & 0.2 & 20.0 & 2.0 \\
\hline S1 & BETUPAP & Betula papyrifera & 0.0 & 0.0 & 1.0 & 0.0 & 0.0 & 0.2 & 0.2 & 20.0 & 2.0 \\
\hline $\mathrm{H}$ & ORTHSEC & Orthilia secunda & 0.1 & 0.1 & 0.0 & 0.1 & 0.0 & 0.1 & 0.0 & 60.0 & 1.9 \\
\hline G & CARESIC & Carex siccata & 0.1 & 0.0 & 0.1 & 0.1 & 0.0 & 0.1 & 0.0 & 60.0 & 1.9 \\
\hline G & ORYZPUN & Oryzopsis pungens & 0.0 & 0.0 & 0.1 & 0.1 & 0.0 & 0.0 & 0.0 & 40.0 & 1.3 \\
\hline G & CALACAN & Calamagrostis canadensis & 0.0 & 0.0 & 0.0 & 0.1 & 0.1 & 0.0 & 0.0 & 40.0 & 1.3 \\
\hline M & PYLAPOL & Pylaisiella polyantha & 0.0 & 0.1 & 0.0 & 0.0 & 0.1 & 0.0 & 0.0 & 40.0 & 1.3 \\
\hline M & PTILCRI & Ptilium crista-castrensis & 0.1 & 0.1 & 0.0 & 0.0 & 0.0 & 0.0 & 0.0 & 40.0 & 1.3 \\
\hline S3 & AMELALN & Amelanchier alnifolia & 0.0 & 0.0 & 0.1 & 0.1 & 0.0 & 0.0 & 0.0 & 40.0 & 1.3 \\
\hline
\end{tabular}


Table 30. (Continued)

\begin{tabular}{|c|c|c|c|c|c|c|c|c|c|c|c|}
\hline \multirow[b]{2}{*}{ Strata } & \multirow[b]{2}{*}{ Code } & \multirow[b]{2}{*}{ Species } & \multicolumn{5}{|c|}{ Plots } & \multirow[b]{2}{*}{ Mean } & \multirow[b]{2}{*}{ SE } & \multirow[b]{2}{*}{ Constancy } & \multirow[b]{2}{*}{ Prominence } \\
\hline & & & P03 & P17 & P18 & $\mathbf{P 2 3}$ & P50 & & & & \\
\hline $\mathrm{H}$ & RUBUPUB & Rubus pubescens & 0.1 & 0.0 & 0.0 & 0.0 & 0.1 & 0.0 & 0.0 & 40.0 & 1.3 \\
\hline M & MOSSES\$S & Moss spp. & 0.0 & 0.0 & 0.0 & 0.1 & 0.1 & 0.0 & 0.0 & 40.0 & 1.3 \\
\hline $\mathrm{H}$ & CAMPROT & Campanula rotundifolia & 0.1 & 0.0 & 0.1 & 0.0 & 0.0 & 0.0 & 0.0 & 40.0 & 1.3 \\
\hline $\mathrm{H}$ & PYROCHL & Pyrola chlorantha & 0.0 & 0.1 & 0.0 & 0.1 & 0.0 & 0.0 & 0.0 & 40.0 & 1.3 \\
\hline M & DICRPOL & Dicranum polysetum & 0.0 & 0.0 & 0.1 & 0.1 & 0.0 & 0.0 & 0.0 & 40.0 & 1.3 \\
\hline $\mathrm{H}$ & EQUIPRA & Equisetum pratense & 0.0 & 0.1 & 0.1 & 0.0 & 0.0 & 0.0 & 0.0 & 40.0 & 1.3 \\
\hline $\mathrm{H}$ & MELALIN & Medicago lupulina & 0.0 & 0.0 & 0.1 & 0.0 & 0.1 & 0.0 & 0.0 & 40.0 & 1.3 \\
\hline $\mathrm{H}$ & LATHOCH & Lathyrus ochroleucus & 0.0 & 0.1 & 0.0 & 0.0 & 0.0 & 0.0 & 0.0 & 20.0 & 0.6 \\
\hline S2 & PRUNPEN & Prunus pensylvanica & 0.0 & 0.0 & 0.0 & 0.0 & 0.1 & 0.0 & 0.0 & 20.0 & 0.6 \\
\hline $\mathrm{H}$ & THALVEN & Thalictrum venulosum & 0.0 & 0.0 & 0.0 & 0.1 & 0.0 & 0.0 & 0.0 & 20.0 & 0.6 \\
\hline G & POAPRAT & Poa pratensis & 0.1 & 0.0 & 0.0 & 0.0 & 0.0 & 0.0 & 0.0 & 20.0 & 0.6 \\
\hline M & BRACSAL & Brachythecium salebrosum & 0.0 & 0.0 & 0.0 & 0.0 & 0.1 & 0.0 & 0.0 & 20.0 & 0.6 \\
\hline $\mathrm{H}$ & EQUILAE & Equisetum laevigatum & 0.0 & 0.0 & 0.0 & 0.1 & 0.0 & 0.0 & 0.0 & 20.0 & 0.6 \\
\hline $\mathrm{H}$ & ASTELAE & Aster laevis & 0.0 & 0.1 & 0.0 & 0.0 & 0.0 & 0.0 & 0.0 & 20.0 & 0.6 \\
\hline S2 & BETUPAP & Betula papyrifera & 0.1 & 0.0 & 0.0 & 0.0 & 0.0 & 0.0 & 0.0 & 20.0 & 0.6 \\
\hline G & SCHIPUR & Schizachne purpurascens & 0.1 & 0.0 & 0.0 & 0.0 & 0.0 & 0.0 & 0.0 & 20.0 & 0.6 \\
\hline $\mathrm{H}$ & EQUISYL & Equisetum sylvaticum & 0.0 & 0.0 & 0.0 & 0.0 & 0.1 & 0.0 & 0.0 & 20.0 & 0.6 \\
\hline M & MOSS\$\$\$ & Moss spp. & 0.0 & 0.1 & 0.0 & 0.0 & 0.0 & 0.0 & 0.0 & 20.0 & 0.6 \\
\hline S2 & POPUTRE & Populus tremuloides & 0.0 & 0.0 & 0.1 & 0.0 & 0.0 & 0.0 & 0.0 & 20.0 & 0.6 \\
\hline $\mathrm{L}$ & CLADMIT & Cladina mitis & 0.0 & 0.0 & 0.1 & 0.0 & 0.0 & 0.0 & 0.0 & 20.0 & 0.6 \\
\hline S3 & CORYCOR & Corylus cornuta & 0.0 & 0.0 & 0.0 & 0.0 & 0.1 & 0.0 & 0.0 & 20.0 & 0.6 \\
\hline $\mathrm{H}$ & TRIEBOR & Trientalis borealis & 0.0 & 0.0 & 0.0 & 0.0 & 0.1 & 0.0 & 0.0 & 20.0 & 0.6 \\
\hline S3 & PRUNVIR & Prunus virginiana & 0.0 & 0.1 & 0.0 & 0.0 & 0.0 & 0.0 & 0.0 & 20.0 & 0.6 \\
\hline $\mathrm{H}$ & EQUISCI & Equisetum scirpoides & 0.0 & 0.1 & 0.0 & 0.0 & 0.0 & 0.0 & 0.0 & 20.0 & 0.6 \\
\hline $\mathrm{H}$ & GEOCLIV & Geocaulon lividum & 0.0 & 0.1 & 0.0 & 0.0 & 0.0 & 0.0 & 0.0 & 20.0 & 0.6 \\
\hline $\mathrm{H}$ & LILIPHI & Lilium philadelphicum & 0.1 & 0.0 & 0.0 & 0.0 & 0.0 & 0.0 & 0.0 & 20.0 & 0.6 \\
\hline $\mathrm{H}$ & ACTARUB & Actaea rubra & 0.1 & 0.0 & 0.0 & 0.0 & 0.0 & 0.0 & 0.0 & 20.0 & 0.6 \\
\hline
\end{tabular}

NatureServe (2004) lists a Populus tremuloides - Quercus macrocarpa / Aralia nudicaulis Forest (CEGL002065) that occurred in the northern tallgrass region of Manitoba, Saskatchewan and the United States. Although Populus tremuloides and Aralia nudicaulis were diagnostic of the type it shares few other similarities with the current classification. A significant difference was the inclusion of Quercus macrocarpa and Ulmus americana as important species for this type. Greenall (1996) lists a Populus tremuloides / Alnus crispa boreal forest community (MB FEC V5) but no other details were available.

The Populus tremuloides / Alnus viridis / Aralia nudicaulis Forest type was similar to the Populus tremuloides / Corylus cornuta / Aralia nudicaulis Forest with the main difference being the constancy and much higher percent cover of Corylus cornuta. Refer to the above section describing this type for ecological site and floristic details of this type. Similarity ratings for related plant community types are provided in Table 31. 
Table 31. Correlation table of plant community types with similarity ratings for the Populus tremuloides / Alnus viridis / Aralia nudicaulis type.

\begin{tabular}{||l|c|l||}
\hline \multicolumn{1}{|c|}{ Similar Types } & $\begin{array}{c}\text { Similarity } \\
\text { Rating }\end{array}$ & \multicolumn{1}{c|}{ Comments } \\
\hline $\begin{array}{l}\text { Populus tremuloides / Alnus viridis / } \\
\text { Aralia nudicaulis CT (Nelson } \text { et al. } \\
\text { 1989) }\end{array}$ & 1 & $\begin{array}{l}\text { Reported to occur in Holmes Crossing and appears to be } \\
\text { the same community type based on similarities in } \\
\text { ecological niche and floristics. }\end{array}$ \\
\hline $\begin{array}{l}\text { Populus tremuloides / Alnus crispa } \\
\text { CT (Allen } \text { et al. 2002) }\end{array}$ & $3(2)$ & $\begin{array}{l}\text { A related type but few details were available for further } \\
\text { comparison. }\end{array}$ \\
\hline $\begin{array}{l}\text { Populus tremuloides - (P. } \\
\text { balsamifera) / Alnus viridis / Aralia } \\
\text { nudicaulis CT (Environmental } \\
\text { Management Associates 1993) }\end{array}$ & 1 & $\begin{array}{l}\text { This was an identical type that was reported to be } \\
\text { common in the Lower Boreal Cordilleran Ecoregion. }\end{array}$ \\
\hline $\begin{array}{l}\text { Populus tremuloides / Alnus crispa } \\
\text { CT (d1.4) (Beckingham and } \\
\text { Archibald 1996) }\end{array}$ & $1(2)$ & $\begin{array}{l}\text { A very similar type in regards to plant composition and } \\
\text { species dominance. Populus balsamifera and Viburnum } \\
\text { edule were co-dominants in this type but not recorded } \\
\text { for the current classification. }\end{array}$ \\
\hline $\begin{array}{l}\text { Populus tremuloides - Picea glauca / } \\
\text { Alnus crispa CT (d2.3) (Beckingham } \\
\text { and Archibald 1996) }\end{array}$ & 3 & $\begin{array}{l}\text { Similar species composition but Picea glauca } \text { was co- } \\
\text { dominant in these stands and there was } \geq 20 \% \text { cover of } \\
\text { Calamagrostis canadensis. }\end{array}$ \\
\hline $\begin{array}{l}\text { Picea glauca / Alnus crispa CT } \\
\text { (d3.2) (Beckingham and Archibald } \\
\text { 1996) }\end{array}$ & 3 & $\begin{array}{l}\text { Similar species composition but overstorey was } \\
\text { dominated by Picea glauca } \text { with only minor cover of } \\
\text { Populus tremuloides. Also much higher cover of feather } \\
\text { mosses. }\end{array}$ \\
\hline $\begin{array}{l}\text { Populus tremuloides - Quercus } \\
\text { macrocarpa / Aralia nudicaulis } \\
\text { Forest (CEGL002065) (NatureServe } \\
\text { 2004) }\end{array}$ & 3 & $\begin{array}{l}\text { Shares some similarities to the current classification but } \\
\text { there were major differences in species composition. } \\
\text { Type was more typical of the northern tall grassland } \\
\text { region where Quercus macrocarpa occurred. }\end{array}$ \\
\hline $\begin{array}{l}\text { Populus tremuloides / Alnus crispa } \\
\text { CT (Greenall 1996) }\end{array}$ & $\begin{array}{l}\text { Boreal forest type but no details were available for } \\
\text { review. }\end{array}$ \\
\hline
\end{tabular}




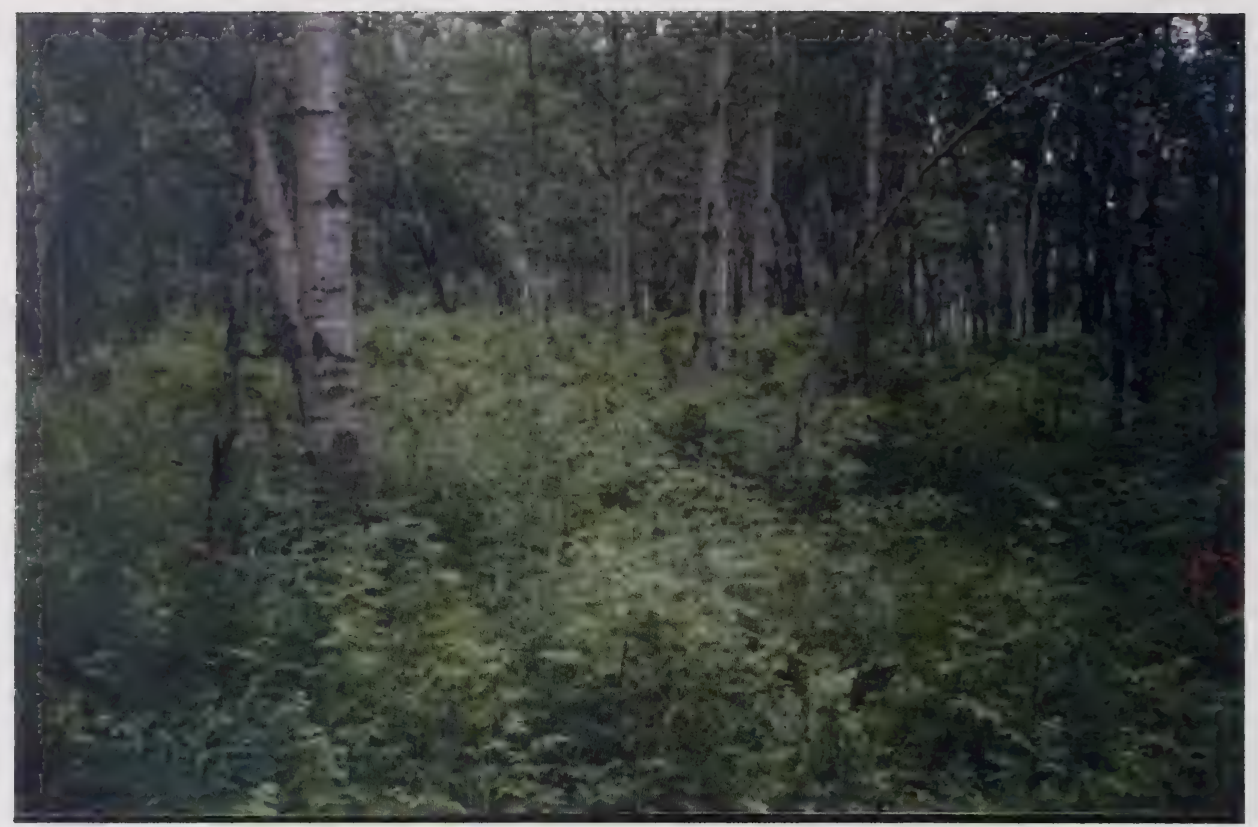

Plate 14. Populus tremuloides / Rosa acicularis / Aralia nudicaulis Forest (P34).

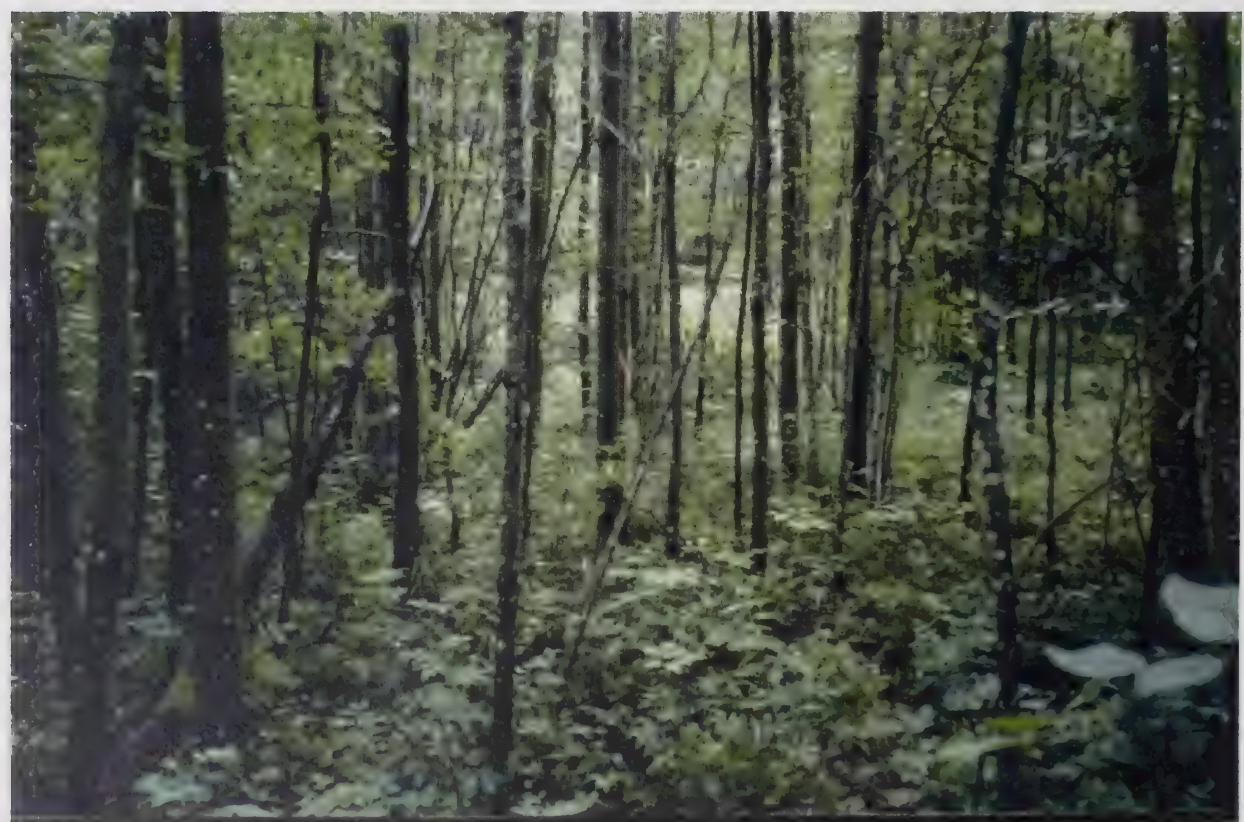

Plate 15. Populus tremuloides / Alnus viridis / Aralia nudicaulis Forest (P50). 


\subsubsection{Betula papyrifera / Ledum groenlandicum / Equisetum sylvaticum Forest}

Paper Birch / Labrador Tea / Woodland Horsetail

This community type occurred in locations that either experienced periodic flooding or inundation by surface runoff. The two sites sampled were both located in the North Buck Lake study area (Table 32). These included a depressional site adjacent to the west shore of North Buck Lake and a shallow drainage channel situated in a toe slope position. The slope gradient on the two sites sampled was less than $7 \%$ and site profiles were concave to straight. Soils at these sites were moderately well drained with subhygric moisture levels and permesotrophic to mesotrophic nutrient regimes. Surface substrate cover was mostly organic matter (93\%) and decaying wood $(7 \%)$. Betula papyrifera formed a closed canopy overstorey with scattered Populus tremuloides and Picea mariana. The shrub layer was variable but typically consisted of Ledum groenlandicum, Alnus viridis, Prunus pensylvanica, and Vaccinium myrtilloides. Prominent species in the herbaceous layer included Equisetum sylvaticum, Aralia nudicaulis, and Calamagrostis canadensis. Other trace species with high constancy included Trientalis borealis, Vaccinium vitis-idaea, and Pleurozium schreberi. Stands were typically small and the diversity of plant species found in these community types was likely influenced by the invasion of common species from adjacent stands.

Class: Forest

Subclass: Deciduous forest

Group: Cold-deciduous forest

Subgroup: Natural/Semi-natural cold-deciduous forest

Formation: Montane or boreal cold-deciduous forest

Alliance: Betula papyrifera Forest Alliance

Association: Betula papyrifera / Ledum groenlandicum / Equisetum sylvaticum Forest

Unique Identifier: $\mathrm{n} / \mathrm{a}$

Classification Confidence Level: 3 (Weak) A distinctive type that was dominated by Betula papyrifera. There were only two plots completed and both were in small stands where adjacent communities likely influenced plant composition. This type was not well documented and the geographical distribution was not known.

Dominant Species: Betula papyrifera, Ledum groenlandicum, Equisetum sylvaticum Co-Dominant Species: Populus tremuloides, Alnus viridis, Prunus pensylvanica, Vaccinium myrtilloides, Aralia nudicaulis

Diagnostic Species: Betula papyrifera, Populus tremuloides, Ledum groenlandicum, Vaccinium myrtilloides, Aralia nudicaulis, Equisetum sylvaticum, Calamagrostis canadensis

\section{Literature Review:}

Timoney and Robinson (1998) noted a Picea glauca / Betula papyrifera / Populus tremuloides / Equisetum pratense forest type in the Ft. Assiniboine Sandhills Wildland Park. This was an old-growth forest but no other details were provided.

Beckingham and Archibald (1996) described a Populus tremuloides - Betula papyrifera / Vaccinium myrtilloides - Ledum groenlandicum type (b2.3) for the boreal mixedwood. This community was distantly related to the current type. However, Populus tremuloides was dominant in the overstorey instead of codominant and Picea glauca was co-dominant rather than absent. Ledum groenlandicum, Vaccinium vitisidaea, Linnaea borealis, Cornus canadensis, and Calamagrostis canadensis cover was higher in this type. In the moss layer Pleurozium schreberi and Hylocomium splendens cover was slightly greater in the b2.3 type. More significantly there was an absence of Equisetum sylvaticum in this type. 
Table 32. Summary of plot data and descriptive statistics for the Betula papyrifera / Ledum groenlandicum / Equisetum sylvaticum community type $(\mathrm{n}=2)$.

\begin{tabular}{|c|c|c|c|c|c|c|c|c|}
\hline \multirow[b]{2}{*}{ Strata } & \multirow[b]{2}{*}{ Code } & \multirow[b]{2}{*}{ Species } & \multicolumn{2}{|c|}{ Plots } & \multirow[b]{2}{*}{ Mean } & \multirow[b]{2}{*}{ SE } & \multirow[b]{2}{*}{ Constancy } & \multirow[b]{2}{*}{ Prominence } \\
\hline & & & P46 & P51 & & & & \\
\hline $\mathrm{T} 1$ & BETUPAP & Betula papyrifera & 70.0 & 70.0 & 70.0 & 0.0 & 100.0 & 83.7 \\
\hline SI & BETUPAP & Betula papyrifera & 7.0 & 3.0 & 5.0 & 2.0 & 100.0 & 22.4 \\
\hline $\mathrm{H}$ & EQUISYL & Equisetum sylvaticum & 5.0 & 4.0 & 4.5 & 0.5 & 100.0 & 21.2 \\
\hline S3 & LEDUGRO & Ledum groenlandicum & 8.0 & 0.1 & 4.1 & 4.0 & 100.0 & 20.1 \\
\hline $\mathrm{Tl}$ & POPUTRE & Populus tremuloides & 1.0 & 5.0 & 3.0 & 2.0 & 100.0 & 17.3 \\
\hline S3 & VACCMYR & Vaccinium myrtilloides & 5.0 & 0.1 & 2.6 & 2.5 & 100.0 & 16.0 \\
\hline $\mathrm{H}$ & ARALNUD & Aralia nudicaulis & 4.0 & 0.1 & 2.1 & 2.0 & 100.0 & 14.3 \\
\hline S1 & POPUTRE & Populus tremuloides & 5.0 & 0.0 & 2.5 & 2.5 & 50.0 & 11.2 \\
\hline S1 & PRUNPEN & Prunus pensylvanica & 4.0 & 0.0 & 2.0 & 2.0 & 50.0 & 10.0 \\
\hline SI & ALNUVIR & Alnus viridis & 0.0 & 4.0 & 2.0 & 2.0 & 50.0 & 10.0 \\
\hline G & CALACAN & Calamagrostis canadensis & 0.1 & 1.0 & 0.6 & 0.5 & 100.0 & 7.4 \\
\hline S2 & PICEMAR & Picea mariana & 0.0 & 2.0 & 1.0 & 1.0 & 50.0 & 7.1 \\
\hline T1 & PICEMAR & Picea mariana & 0.0 & 2.0 & 1.0 & 1.0 & 50.0 & 7.1 \\
\hline S3 & PRUNPEN & Prunus pensylvanica & 1.0 & 0.0 & 0.5 & 0.5 & 50.0 & 5.0 \\
\hline M & PLEUSCH & Pleurozium schreberi & 0.1 & 0.1 & 0.1 & 0.0 & 100.0 & 3.2 \\
\hline $\mathrm{H}$ & TRIEBOR & Trientalis borealis & 0.1 & 0.1 & 0.1 & 0.0 & 100.0 & 3.2 \\
\hline S3 & VACCVIT & Vaccinium vitis-idaea & 0.1 & 0.1 & 0.1 & 0.0 & 100.0 & 3.2 \\
\hline M & PTILCRI & Ptilium crista-castrensis & 0.0 & 0.1 & 0.1 & 0.1 & 50.0 & 1.6 \\
\hline M & MOSS\$\$ $\$$ & Unidentified Moss & 0.0 & 0.1 & 0.1 & 0.1 & 50.0 & 1.6 \\
\hline S3 & CORNCAN & Cornus canadensis & 0.0 & 0.1 & 0.1 & 0.1 & 50.0 & 1.6 \\
\hline M & HYLOSPL & Hylocomium splendens & 0.0 & 0.1 & 0.1 & 0.1 & 50.0 & 1.6 \\
\hline S3 & ROSAACI & Rosa acicularis & 0.0 & 0.1 & 0.1 & 0.1 & 50.0 & 1.6 \\
\hline S3 & RUBUPUB & Rubus pubescens & 0.0 & 0.1 & 0.1 & 0.1 & 50.0 & 1.6 \\
\hline G & CAREDIS & Carex disperma & 0.0 & 0.1 & 0.1 & 0.1 & 50.0 & 1.6 \\
\hline S3 & AMELALN & Amelanchier alnifolia & 0.1 & 0.0 & 0.1 & 0.1 & 50.0 & 1.6 \\
\hline S3 & LINNBOR & Linnaea borealis & 0.0 & 0.1 & 0.1 & 0.1 & 50.0 & 1.6 \\
\hline S1 & SALIBEB & Salix bebbiana & 0.0 & 0.1 & 0.1 & 0.1 & 50.0 & 1.6 \\
\hline S3 & LONIINV & Lonicera involucrata & 0.0 & 0.1 & 0.1 & 0.1 & 50.0 & 1.6 \\
\hline S1 & SALIPSE & Salix pseudomonticola & 0.0 & 0.1 & 0.1 & 0.1 & 50.0 & 1.6 \\
\hline M & DICRPOL & Dicranum polysetum & 0.1 & 0.0 & 0.1 & 0.1 & 50.0 & 1.6 \\
\hline $\mathrm{H}$ & LYCOANN & Lycopodium annotinum & 0.0 & 0.1 & 0.1 & 0.1 & 50.0 & 1.6 \\
\hline S3 & RIBETRI & Ribes triste & 0.0 & 0.1 & 0.1 & 0.1 & 50.0 & 1.6 \\
\hline
\end{tabular}

Mackenzie River Basin Committee (1981) identified a Picea glauca / Betula neoalaskana community at Lake Athabasca. This stand type was found along riparian and old beach habitats and may be climax stage of the current classification. It was a mature stand with Picea glauca attaining $41 \mathrm{~cm}$ to $60 \mathrm{~cm}$ diameter at breast height and supports a mesophytic undergrowth. A second type was identified as Betula neoalaskana / Salix spp. found on moraines, stream sides and lakeshores. Picea mariana was co-dominant and common species in the shrub layer included Salix spp. Ledum groenlandicum, Chamaedaphne calyculata, and Vaccinium vitis-idaea. Pleurozium schreberi dominated the moss layer and was associated with Hylocomium splendens, and Ptilium ciliare.

NatureServe (2004) describes a Betula papyrifera / Diervilla lonicera - (Abies balsamea) Forest (CEGL002463) found in the northern Great Lakes region including Ontario and possibly Manitoba. Betula papyrifera was the dominant canopy tree and may be associated with Populus tremuloides, Abies balsamea, Picea glauca, and Pinus banksiana. Although the overstorey was similar this type had a drier moisture regime and there was little similarity in the shrub and herbaceous layers. The dominant shrub 
was Abies balsamea and associated shrubs include Corylus cornuta, Diervilla lonicera, Rosa acicularis, and Taxus canadensis. The herbaceous layer included Aralia nudicaulis, Eurybia macrophylla (= Aster macrophyllus), Clintonia borealis, Cornus canadensis, Maianthemum canadense, and Trientalis borealis. Similarity ratings for related plant community types are provided in Table 33.

Table 33. Correlation table of plant community types with similarity ratings for the Betula papyrifera / Ledum groenlandicum / Equisetum sylvaticum type.

\begin{tabular}{||l|c|l||}
\hline \multicolumn{1}{|c|}{ Similar Types } & $\begin{array}{c}\text { Similarity } \\
\text { Rating }\end{array}$ & \multicolumn{1}{c|}{ Comments } \\
\hline \hline $\begin{array}{l}\text { Picea glauca / Betula papyrifera / } \\
\text { Populus tremuloides / Equisetum } \\
\text { pratense CT (Timoney and Robinson } \\
\text { 1998) }\end{array}$ & 3 & $\begin{array}{l}\text { Betula papyrifera was not dominant in this type however } \\
\text { it was likely related to the current one. More details } \\
\text { were required regarding floristics and site characteristics } \\
\text { to make a more exact determination. }\end{array}$ \\
\hline $\begin{array}{l}\text { Populus tremuloides - Betula } \\
\text { papyrifera / Vaccinium myrtilloides - } \\
\text { Ledum groenlandicum CT (b2.3) } \\
\text { (Beckingham and Archibald 1996) }\end{array}$ & 3 & $\begin{array}{l}\text { Considerable differences in species composition and } \\
\text { dominance. No Equisetum sylvaticum was recorded for } \\
\text { this type. }\end{array}$ \\
\hline $\begin{array}{l}\text { Picea glauca / Betula neoalaskana } \\
\text { CT (Mackenzie River Basin } \\
\text { Committee 1981) }\end{array}$ & 3 & $\begin{array}{l}\text { Betula neoalaskana } \text { was dominant but it appears to } \\
\text { occupy similar habitats and possibly the current type } \\
\text { succeeds to this climax stage. Has a mesophytic } \\
\text { understorey but few details are available regarding plant } \\
\text { species composition. }\end{array}$ \\
\hline $\begin{array}{l}\text { Betula neoalaskana / Salix spp. CT } \\
\text { (Mackenzie River Basin Committee } \\
\text { 1981) }\end{array}$ & 3 & $\begin{array}{l}\text { Betula neoalaskana was dominant in the tree layer. } \\
\text { Some similarities in the shrub and moss layer but } \\
\text { important differences in species dominance. }\end{array}$ \\
\hline $\begin{array}{l}\text { Betula papyrifera / Diervilla lonicera } \\
\text {-(Abies balsamea) Forest } \\
\text { (CEGL002463) (NatureServe 2004) }\end{array}$ & 3 & $\begin{array}{l}\text { Similar overstorey but it occurred on drier sites resulting } \\
\text { in differences in the species composition of the shrub } \\
\text { and herb layers. Also differences in composition } \\
\text { attributed to the wide geographical separation of these } \\
\text { two types. }\end{array}$ \\
\hline
\end{tabular}

\subsubsection{Betula papyrifera - Pinus banksiana / Alnus incana spp tenuifolia / Aralia nudicaulis Forest} Paper Birch - Jack Pine / River Alder / Sarsaparilla Forest

Mixed Betula papyrifera - Pinus banksiana stands were observed in a few localities within the Holmes Crossing Sandhills Ecological Reserve but did not appear to be as common in the North Buck Lake study area. Stands were small and not well defined, but generally occurred along the cool north sides of transverse sand dunes. Only one site was sampled in Holmes Crossing Sandhills Ecological Reserve (Table 34). This community was situated in an upper to mid-slope position of a north facing low sand dune with a $20 \%$ slope gradient. The soil was well drained with mesic moisture conditions and mesotrophic soil nutrient levels. Surface substrates were $97 \%$ organic matter and $3 \%$ decaying wood. Species composition was likely variable because of the invasion of plant species from adjacent community types. The overstorey at the plot completed was a mixture of Betula papyrifera and Pinus banksiana. Picea glauca was present in the shrub layer indicating potential succession of stands to this species in the absence of wildfire. The shrub layer was relatively open at approximately $26 \%$ cover and was dominated by Alnus incana spp tenuifolia, Rosa acicularis, Vaccinium myrtilloides, and Vaccinium vitis-idaea. Aralia nudicaulis (7\% cover) was the dominant herb with only minor cover of Geocaulon lividum, Maianthemum canadense, Rubus pubescens, Galium boreale, Viola adunca and Campanula rotundifolia. Graminoids were sparse with less than $2 \%$ cover consisting of Leymus innovatus and Carex siccata. Pleurozium schreberi and Hylocomium splendens dominate the moss layer at $20 \%$ and $15 \%$ cover, 
respectively. Trace amounts of Dicranum polysetum and Ptilium crista-castrensis were also present. Usnea spp. was present at $25 \%$ cover.

Class: Forest

Subclass: Deciduous forest

Group: Cold-deciduous forest

Subgroup: Natural/Semi-natural cold-deciduous forest

Formation: Montane or boreal cold-deciduous forest

Alliance: Betula papyrifera Forest Alliance

Association: Betula papyrifera - Pinus banksiana / Alnus incana spp tenuifolia / Aralia nudicaulis Forest Unique Identifier: $\mathrm{n} / \mathrm{a}$

Classification Confidence Level: 3 (Weak) Only one plot was completed in this type and it was not well correlated to other types described in the literature. Geographical distribution of this community type was unknown.

Dominant Species: Betula papyrifera, Pinus banksiana, Alnus incana spp tenuifolia, Aralia nudicaulis, Pleurozium schreberi, Hylocomium splendens, Usnea spp

Co-Dominant Species: Rosa acicularis, Vaccinium myrtilloides, Vaccinium vitis-idaea

Diagnostic Species: Betula papyrifera, Pinus banksiana, Alnus incana spp tenuifolia, Aralia nudicaulis, Pleurozium schreberi, Hylocomium splendens

\section{Literature Review:}

Nelson et al. (1989) described a Pinus banksiana / Alnus crispa / Linnaea borealis - Vaccinium vitis-idaea community that occurred in the Holmes Crossing Sandhills Ecological Reserve. This type also occurred on northerly aspects and has very similar species composition. The main difference was that Pinus banksiana formed closed canopy stands (45\% mean cover) and Betula papyrifera cover was less than $6 \%$. Also there was no cover of Alnus incana spp. tenuifolia recorded in the plots completed by Nelson et al. (1989). Aralia nudicaulis percent cover was similar in both types. The moss layer in both types was very similar with Pleurozium schreberi and Hylocomium splendens being dominant.

Allen et al. (2002) reported a Betula papyrifera / Alnus crispa / Elymus innovatus community type from the La Butte Creek Wildland Provincial Park located north of Lake Athabasca. This community had an open shrub layer and occurred as small stands. A second type identified in the Park was a Betula papyrifera / Rosa acicularis community. This type also occurred as small closed canopy stands with a sparse understorey consisting mainly of Orthilia secunda, Pyrola asarifolia, and leaf litter. Allen and Johnson (no date.) described a Betula papyrifera / Vaccinium vitis-idaea (CT 1) type from the Maybelle River Wildland Park. This uncommon type $(n=1)$ was a mature stand occurring on the leading edge of dunes in mid-slope positions with moderately steep slope gradients $\left(25^{\circ}\right)$. Aspects were northeast and soils were rapidly drained sands that had subxeric moisture regimes. The overstorey canopy was closed but the understorey was relatively open. Most white birch stands noted in this study area and adjacent lands were Betula papyrifera / Vaccinium myrtilloides communities. The rare Betula papyrifera / Vaccinium vitisidaea / Cladina mitis community was a more mesic type with Picea mariana and Alnus crispa (4\% cover) present in the understorey.

The Betula papyrifera / Diervilla lonicera - (Abies balsamea) Forest (CEGL002463) occurred in the northern Great Lakes region including Ontario and possibly Manitoba (NatureServe 2004). This type has a very similar overstorey composition. Betula papyrifera was dominant in the overstorey but Populus tremuloides, Abies balsamea, Picea glauca, and Pinus banksiana may also be associated with this type. Typically sites were submesic to mesic which was similar to the current classification. The shrub was composed of different species including Diervilla lonicera, Abies balsamea, and Corylus cornuta. Species in common between the two types included Rosa acicularis, Aralia nudicaulis, and Maianthemum 
canadense. Other common herbs include Eurybia macrophylla (=Aster macrophyllus), Clintonia borealis, Cornus canadensis, and Trientalis borealis.

NatureServe (2004) also lists an Abies balsamea - Betula papyrifera / Diervilla lonicera Forest (CEGL002474). This community type also occurred in Manitoba and Ontario. The canopy ranges from pure Abies balsamea to mixed stands with Betula papyrifera or sometimes Populus tremuloides, Picea glauca, and Picea mariana. Pinus strobus and Thuja occidentalis may also be found in these stands. Mosses also included Hylocomium splendens, Pleurozium schreberi, and Ptilium crista-castrensis. Species not native to Alberta included Acer spicatum, Diervilla lonicera, Sorbus americana, Eurybia macrophylla (=Aster macrophyllus), and others. Similarity ratings for related plant community types are provided in Table 35.

Table 34. Summary of plot data and descriptive statistics for the Betula papyrifera - Pinus banksiana / Alnus incana $\mathrm{spp}$ tenuifolia / Aralia nudicaulis community type $(\mathrm{n}=1)$.

\begin{tabular}{|c|c|c|c|c|c|c|c|}
\hline \multirow[b]{2}{*}{ Strata } & \multirow[b]{2}{*}{ Code } & \multirow[b]{2}{*}{ Species } & \multirow{2}{*}{$\begin{array}{l}\text { Plot } \\
\text { P05 } \\
\end{array}$} & \multirow[b]{2}{*}{ Strata } & \multirow[b]{2}{*}{ Code } & \multirow[b]{2}{*}{ Species } & \multirow{2}{*}{$\begin{array}{l}\text { Plot } \\
\text { P05 } \\
\end{array}$} \\
\hline & & & & & & & \\
\hline $\mathrm{T} 1$ & BETUPAP & Betula papyrifera & 30.0 & S2 & PRUNPEN & Prunus pensylvanica & 1.0 \\
\hline $\mathrm{E}$ & USNEA\$\$\$ & Usnea spp. & 25.0 & S2 & PICEGLA & Picea glauca & 1.0 \\
\hline $\mathrm{T} 1$ & PINUBAN & Pinus banksiana & 25.0 & S3 & RUBUPUB & Rubus pubescens & 1.0 \\
\hline$M$ & PLEUSCH & Pleurozium schreberi & 20.0 & S1 & PICEGLA & Picea glauca & 1.0 \\
\hline M & HYLOSPL & Hylocomium splendens & 15.0 & G & CARESIC & Carex siccata & 0.1 \\
\hline S1 & ALNUTEN & $\begin{array}{l}\text { Alnus incana } \mathrm{spp} \\
\text { tenuifolia }\end{array}$ & 10.0 & M & DICRPOL & Dicranum polysetum & 0.1 \\
\hline $\mathrm{H}$ & ARALNUD & Aralia nudicaulis & 7.0 & $\mathrm{~L}$ & CLADMIT & Cladina mitis & 0.1 \\
\hline S3 & VACCMYR & Vaccinium myrtilloides & 6.0 & S2 & AMELALN & Amelanchier alnifolia & 0.1 \\
\hline S2 & ROSAACI & Rosa acicularis & 4.0 & M & PTILCRI & Ptilium crista-castrensis & 0.1 \\
\hline S3 & VACCVIT & Vaccinium vitis-idaea & 2.0 & S2 & PRUNVIR & Prunus virginiana & 0.1 \\
\hline $\mathrm{H}$ & GEOCLIV & Geocaulon lividum & 1.0 & $\mathrm{H}$ & GALIBOR & Galium boreale & 0.1 \\
\hline G & ELYMINN & Leymus innovatus & 1.0 & S3 & LINNBOR & Linnaea borealis & 0.1 \\
\hline $\mathrm{H}$ & MAIACAN & $\begin{array}{l}\text { Maianthemum } \\
\text { canadense }\end{array}$ & 1.0 & $\mathrm{H}$ & VIOLADU & Viola adunca & 0.1 \\
\hline S3 & RUBUIDA & Rubus idaeus & 1.0 & $\mathrm{H}$ & CAMPROT & Campanula rotundifolia & 0.1 \\
\hline
\end{tabular}


Table 35. Correlation table of plant community types with similarity ratings for the Betula papyriferaPinus banksiana / Alnus incana spp tenuifolia / Aralia nudicaulis type.

\begin{tabular}{|l|c|l||}
\hline \multicolumn{1}{|c|}{ Similar Types } & $\begin{array}{c}\text { Similarity } \\
\text { Rating }\end{array}$ & \multicolumn{1}{c|}{ Comments } \\
\hline $\begin{array}{l}\text { Pinus banksiana / Alnus crispa / Linnaea } \\
\text { borealis - Vaccinium vitis-idaea CT } \\
\text { (Nelson } \text { et al. } \text { 1989) }\end{array}$ & 2 & $\begin{array}{l}\text { Very similar species composition yet quite different in } \\
\text { terms of species that were dominant. Occurred in the } \\
\text { Holmes Crossing Sandhills Ecological Reserve. }\end{array}$ \\
\hline $\begin{array}{l}\text { Betula papyrifera / Alnus crispa / Elymus } \\
\text { innovatus CT (Allen } \text { et al. 2002) }\end{array}$ & 3 & $\begin{array}{l}\text { This appears to be a related type by few details were } \\
\text { available and additional study was required of site } \\
\text { characteristics and floristics. }\end{array}$ \\
\hline $\begin{array}{l}\text { Betula papyrifera / Rosa acicularis CT } \\
\text { (Allen } \text { et al. } \text { 2002) }\end{array}$ & 3 & $\begin{array}{l}\text { This appears to be a related type by few details were } \\
\text { available and additional study was required of site } \\
\text { characteristics and floristics. }\end{array}$ \\
\hline $\begin{array}{l}\text { Betula papyrifera / Vaccinium vitis-idaea } \\
\text { CT (Allen and Johnson no date) }\end{array}$ & 2 & $\begin{array}{l}\text { A similar stand type that also occupies cool north } \\
\text { facing dune slopes. Vaccinium vitis-idaea cover was } \\
\text { lower in the current type but generally it was a good fit. }\end{array}$ \\
\hline $\begin{array}{l}\text { Betula papyrifera / Vaccinium myrtilloides } \\
\text { CT (Allen and Johnson no date) }\end{array}$ & 2 & $\begin{array}{l}\text { Likely a similar type but no details were available to } \\
\text { allow a direct comparison. }\end{array}$ \\
\hline $\begin{array}{l}\text { Betula papyrifera / Vaccinium vitis-idaea } \\
\text { / Cladina mitis CT (Allen and Johnson } \\
\text { no date) }\end{array}$ & 3 & $\begin{array}{l}\text { Possibly a related type occupying slightly different } \\
\text { ecological niche. No details were available to allow a } \\
\text { direct comparison. }\end{array}$ \\
\hline $\begin{array}{l}\text { Betula papyrifera / Diervilla lonicera }- \\
\text { (Abies balsamea) Forest (CEGL002463) } \\
\text { (NatureServe 2004) }\end{array}$ & 3 & $\begin{array}{l}\text { Some similarities in overstorey and understorey species } \\
\text { but important differences in species composition. This } \\
\text { type possibly extends west into Manitoba }\end{array}$ \\
\hline $\begin{array}{l}\text { Abies balsamea } \text { - Betula papyrifera / } \\
\text { Diervilla lonicera Forest (CEGL002474) } \\
\text { (NatureServe 2004) }\end{array}$ & 3 & $\begin{array}{l}\text { Similar floristics but different from current } \\
\text { classification in the dominance of } \text { Abies balsamea } \\
\text { reduced cover of Betula papyrifera, and presence of } \\
\text { species in all strata that were non-native to Alberta. }\end{array}$ \\
\hline
\end{tabular}




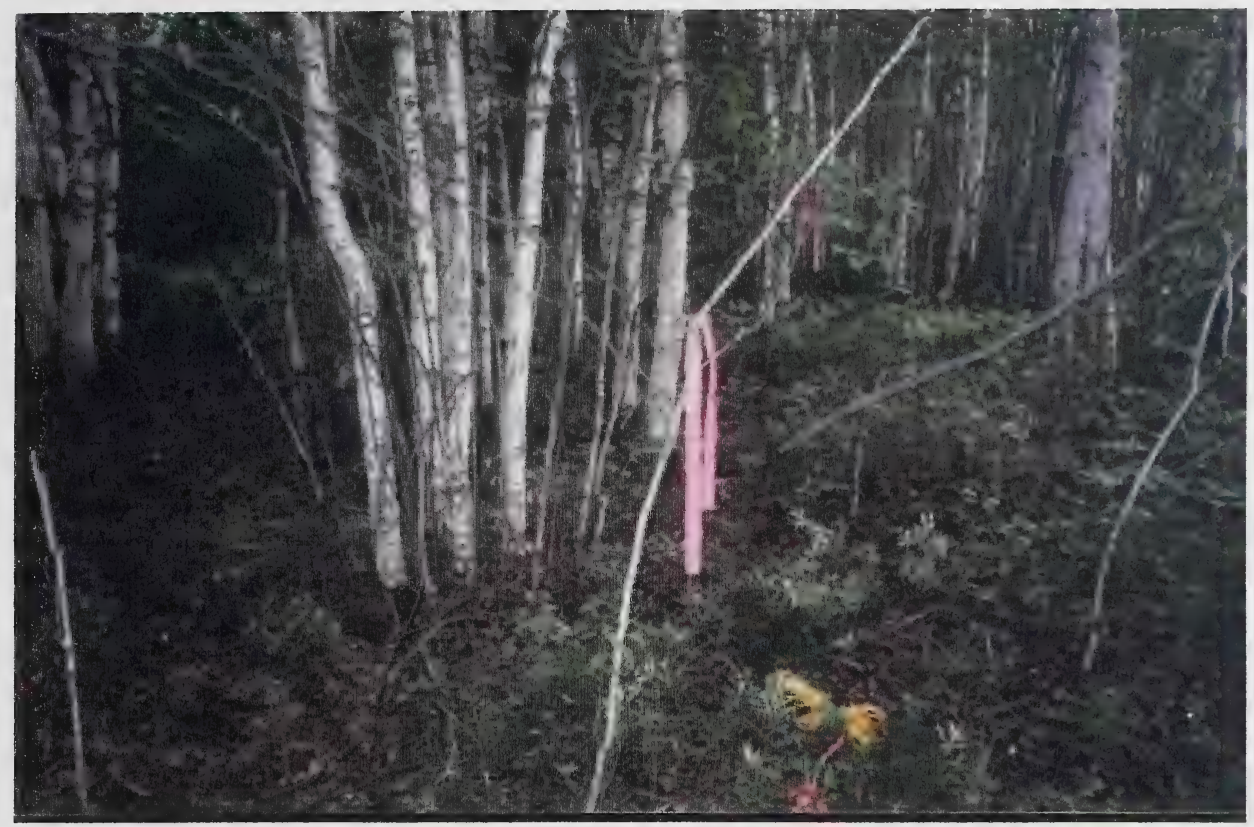

Plate 16. Betula papyrifera / Ledum groenlandicum / Equisetum sylvaticum Forest (P46).

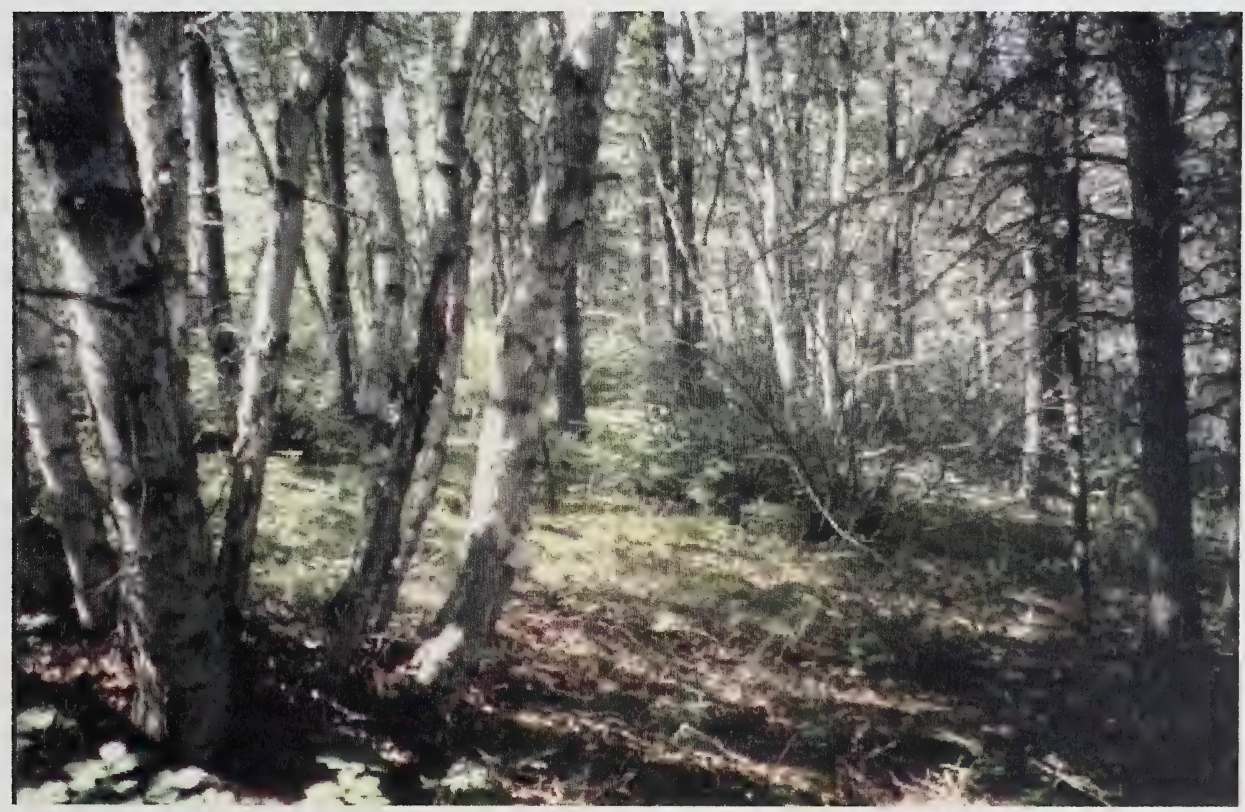

Plate 17. Betula papyrifera-Pinus banksiana /Alnus incana spp tenuifolia /Aralia nudicaulis Forest (P5). 


\subsubsection{Shrubland}

\subsubsection{Betula pumila - (Salix spp.)/Carex diandra / Aulacomnium palustre Shrubland}

Dwarf Birch - (Willow) / Two-stamened Sedge / Tufted Moss Shrubland

This community type was encountered once in the Holmes Crossing Sandhills Ecological Reserve (Table 36). This was a level site in a depressional area where the water table remained permanently near the ground surface. Flooding may occur seasonally and sites were poorly drained with subhydric moisture levels. The soils were thick layers of Organic material with a mesotrophic nutrient regime. Surface substrate cover was mainly organic material (94\%) with some standing water $(6 \%)$ and traces of decaying wood. Betula pumila cover (41\%) dominated the shrub layer, which also included minor percent cover of Salix petiolaris, Salix planifolia, Salix pedicellaris, Salix bebbiana, Larix laricina, and Andromeda polifolia. Carex diandra was the dominant graminoid at 50\% cover followed by Calamagrostis stricta cover at $25 \%$ and Calamagrostis canadensis as a minor species. Total herb cover was less than $2 \%$ and included Potentilla palustris, Equisetum fluviatile, and Epilobium palustre. Moss cover was moderate and included Aulacomnium palustre (25\%), Drepanocladus aduncus (8\%), and Tomentypnum nitens (7\%).

Class: Shrubland

Subclass: Deciduous Shrubland

Group: Cold-deciduous shrubland

Subgroup: Natural/Semi-natural cold-deciduous shrubland

Formation: Saturated cold-deciduous shrubland

Alliance: Betula pumila - (Salix spp.) Saturated Shrubland Alliance

Association: Betula pumila - (Salix spp.) / Carex diandra / Aulacomnium palustre Shrubland

Unique Identifier: Potentially the same type as Alberta element CEAB000126.

Classification Confidence Level: 2 (Moderate) Only one plot completed in this type and further sampling was required to better describe the type. A number of similar types are reported in the literature but the geographical range for the type was uncertain.

Dominant Species: Betula pumila, Carex diandra, Aulacomnium palustre

Co-Dominant Species: Salix petiolaris, Calamagrostis stricta, Calamagrostis canadensis,

Drepanocladus aduncus, Tomentypnum nitens

Diagnostic Species:_Betula pumila, Carex diandra, Equisetum fluviatile, Potentilla palustris

Aulacomnium palustre, Drepanocladus aduncus, Tomentypnum nitens

Table 36. Summary of plot data and descriptive statistics for the Betula pumila - (Salix spp.)/ Carex diandra / Aulacomnium palustre Shrubland community type $(\mathrm{n}=1)$.

\begin{tabular}{|cllc|}
\hline & & & \multicolumn{1}{c|}{ Plot } \\
\cline { 4 - 4 } Strata & Code & \multicolumn{1}{c|}{ P32 } \\
\hline G & CAREDIA & Carex diandra & 50.0 \\
S2 & BETUPUM & Betula pumila & 41.0 \\
M & AULAPAL & Aulacomnium palustre & 25.0 \\
G & CALASTR & Calamagrostis stricta & 15.0 \\
M & DREPADU & Drepanocladus aduncus & 8.0 \\
M & TOMENIT & Tomentypnum nitens & 7.0 \\
S3 & SALIPET & Salix petiolaris & 2.0 \\
G & CALACAN & Calamagrostis canadensis & 2.0 \\
S1 & PINUBAN & Pinus banksiana & 1.0 \\
\hline
\end{tabular}

\begin{tabular}{|c|c|c|c|}
\hline & & & Plot \\
\hline Strata & Code & Species & P32 \\
\hline $\mathrm{S} 1$ & LARILAR & Larix laricina & 1.0 \\
\hline $\mathrm{H}$ & POTEPAL & Potentilla palustris & 1.0 \\
\hline S3 & SALIPLA & Salix planifolia & 0.1 \\
\hline $\mathrm{H}$ & EQUIFLU & Equisetum fluviatile & 0.1 \\
\hline G & POAPALU & Poa palustris & 0.1 \\
\hline S3 & SALIPED & Salix pedicellaris & 0.1 \\
\hline S3 & ANDRPOL & Andromeda polifolia & 0.1 \\
\hline $\mathrm{H}$ & EPILPAL & Epilobium palustre & 0.1 \\
\hline S3 & SALIBEB & Salix bebbiana & 0.1 \\
\hline
\end{tabular}




\section{Literature Review:}

Nelson et al. (1989) completed two plots to describe a Shallow Water Community Type occurring in the Holmes Crossing area. This type appears to be very similar to the community type proposed in the current study, however, it was adjacent shallow ponds and included emergent zone vegetation such as Nuphar variegatum and Potamogeton spp. The one site sampled on the present study was located in a large depression with no open water. Timoney and Robinson (1998) noted a Larix / Betula pumila / Drepanocladus sp. (brown moss) community that occurred in the Ft. Assiniboine Sandhills Wildland. Muhlenbergia glomerata was found to be a component species within this type.

Allen and Johnson (no date.) described a Salix spp. - Betula pumila community type that occurred in the Marguerite Crag and Tail Wildland Park in northeastern Alberta. No additional details were provided other than it occurred in a wetland located between sand deposits and the Marguerite River. Meijer (2002c) identified a Betula pumila / Carex spp. / Drepanocladus sp. type that occurred in this same Park. This type had a similar species composition but percent coverage of the dominant species was substantially different. Percent cover of Betula pumila, Carex diandra, and Aulacomnium palustre were all much less and were recorded at $5 \%, 1 \%$ and $0 \%$ cover, respectively. Drepanocladus sp. was recorded at $70 \%$ cover.

Beckingham and Archibald (1996) described a Betula pumila / Carex spp. / Tomentypnum nitens type (k.2.1) in the boreal mixedwood of Alberta. This type appeared to be wetter but had very similar cover of the dominants and diagnostic species. However, in contrast to the Holmes Crossing plot dominants in this type included Sphagnum spp., Smilacina trifolia, Caltha palustris, and Menyanthes trifoliata. This may possibly be attributed to lower than normal water tables in the Holmes Crossing area.

Allen (2004) lists a Betula pumila - Salix spp. / Carex spp. (CEAB000126) that occurred in Parkland string fens and sand plain fens (Wallis 1990). It was a disjunct community in the Parkland and occurrences were extremely localised. This was likely a very similar type although no floristic details were available for review. According to Allen (2004) this type was not well defined and additional work was required to more accurately describe it. Currently this type has a S3? Rating in the province. Cottonwood Consultants Ltd. (1986) gives a brief account of a Betula pumila wetland type that occurred in interdune depressions in the Wainwright area. A variety of Salix spp. were recorded for this type but only Salix planifolia was common to the current classification. Other species in common included Carex diandra, Calamagrostis canadensis, Equisetum fluviatile, Potentilla palustris, Drepanocladus aduncus, and Tomentypnum nitens. A number of other boreal wetland species were recorded for this type notably Carex aquatilis, C. interior, C. limosa, C. serissima, Menyanthes trifoliata, Muhlenbergia glomerata, Viola nephrophylla, and Sphagnum spp.

Greenall (1996) described a Salix planifolia - Betula pumila var. glandulifera Shrubland (CEGL002529) that was listed on NatureServe (2004). This type occurred in Manitoba but no details were available regarding species composition for the community. A Betula nana / Carex utriculata Shrubland (CEGL001079) was described by NatureServe (2004). This community occupies marshes in the subalpine and montane riparian zones of Alberta and some areas of the western United States. The dominant shrub species was Betula nana (= Betula glandulosa) and other associated shrubs include Salix planifolia, Salix geyeriana, Salix wolfii, Rhamnus alnifolia, Dasiphora fruticosa spp. floribunda (= Pentaphylloides floribunda), Cornus sericea, Alnus incana, and Ribes spp. Carex utriculata dominates the herbaceous layer that also included Calamagrostis stricta, Carex aquatilis, Carex livida, and Carex lasiocarpa. Forb cover included Cicuta maculata, Comarum palustre, Mentha arvensis, Galium spp., Ranunculus sceleratus, Sparganium natans (= Sparganium minimum), and Thalictrum alpinum. 
NatureServe (2004) describes a Betula pumila - Salix spp. Prairie Fen Shrubland (CEGL002189) that occurred in the northern tallgrass prairie and adjacent prairie-forest border regions of the upper midwestern United States and extending into Manitoba. The shrub layer was dominated by Betula pumila and Salix spp were present as well. The herb/graminoid was well developed and included Calamagrostis canadensis, Calamagrostis stricta, Carex aquatilis, Carex lasiocarpa, Eriophorum angustifolium, Lobelia kalmii, Lycopus uniflorus, and other species. Mosses were sparse to abundant and dominated by species other than Sphagnum spp. Greenall (1996) listed a Betula pumila - Salix spp. Rich Boreal Fen Shrubland and a Betula pumila / Carex lasiocarpa Poor Fen Shrubland, but no details were provided for either. Similarity ratings for related plant community types are provided in Table 37.

Table 37. Correlation table of plant community types with similarity ratings for the Betula pumila - (Salix spp.) / Carex diandra / Aulacomnium palustre Shrubland type.

\begin{tabular}{|c|c|c|}
\hline Similar Types & $\begin{array}{c}\text { Similarity } \\
\text { Rating }\end{array}$ & Comments \\
\hline $\begin{array}{l}\text { Shallow Water CT (Nelson et al. } \\
\text { 1989) }\end{array}$ & 1 & $\begin{array}{l}\text { Identical type with very similar species composition and } \\
\text { occupying the same type of habitat. }\end{array}$ \\
\hline $\begin{array}{l}\text { Larix/Betula pumila/Drepanocladus } \\
\text { sp. CT (Timoney and Robinson 1998) }\end{array}$ & 3 & $\begin{array}{l}\text { Betula pumila was a dominant in this type but no further } \\
\text { details were provided regarding floristics of this type. }\end{array}$ \\
\hline $\begin{array}{l}\text { Salix spp. - Betula pumila CT (Allen } \\
\text { and Johnson no date) }\end{array}$ & 2 & $\begin{array}{l}\text { Appears to be a similar type however no details } \\
\text { regarding floristics were available for this review. }\end{array}$ \\
\hline $\begin{array}{l}\text { Betula pumila / Carex spp. / } \\
\text { Drepanocladus sp. CT (Meijer } \\
\text { 2002c) }\end{array}$ & 2 & $\begin{array}{l}\text { A very similar type. The main difference seems to be in } \\
\text { the percent cover of the dominant species. }\end{array}$ \\
\hline $\begin{array}{l}\text { Betula pumila / Carex spp. / } \\
\text { Tomentypnum nitens } \text { CT (k.2.1) } \\
\text { (Beckingham and Archibald 1996) }\end{array}$ & $1(2)$ & $\begin{array}{l}\text { Appears to be the same type based on similarities in } \\
\text { diagnostic and dominant species but the plot completed } \\
\text { on the present study was drier. }\end{array}$ \\
\hline $\begin{array}{l}\text { Betula pumila - Salix spp. / Carex } \\
\text { spp. CT (CEAB000126) Allen (2004) }\end{array}$ & 2 & $\begin{array}{l}\text { Appears to be the same type but insufficient details } \\
\text { provided to increase similarity rating. }\end{array}$ \\
\hline $\begin{array}{l}\text { Betula pumila wetland type } \\
\text { (Cottonwood Consultants Ltd. 1986) }\end{array}$ & 2 & $\begin{array}{l}\text { Few details were provided but it appears to be a very } \\
\text { similar community type. }\end{array}$ \\
\hline $\begin{array}{l}\text { Salix planifolia - Betula pumila var. } \\
\text { glandulifera Shrubland } \\
\text { (CEGL002529) (Greenall 1996, } \\
\text { NatureServe 2004) }\end{array}$ & 3 & $\begin{array}{l}\text { Dominant species occur in the Betula pumila - (Salix } \\
\text { spp.) / Carex diandra / Aulacomnium palustre Shrubland } \\
\text { but no other details regarding floristics were reviewed. }\end{array}$ \\
\hline $\begin{array}{l}\text { Betula nana / Carex utriculata } \\
\text { Shrubland (CEGL001079) } \\
\text { NatureServe (2004) }\end{array}$ & 3 & $\begin{array}{l}\text { Although this type has similar structure and ecological } \\
\text { site conditions it occurred in subalpine and montane } \\
\text { riparian areas and there were many differences in the } \\
\text { floristics. }\end{array}$ \\
\hline $\begin{array}{l}\text { Betula pumila - Salix spp. Prairie Fen } \\
\text { Shrubland (CEGL002189) } \\
\text { NatureServe (2004) }\end{array}$ & 3 & $\begin{array}{l}\text { Similar structure and shares some of the same species } \\
\text { but there were many differences in floristics and does not } \\
\text { extend into the boreal forest region. }\end{array}$ \\
\hline $\begin{array}{l}\text { Betula pumila / Carex lasiocarpa } \\
\text { Poor Fen Shrubland (Greenall 1996) }\end{array}$ & 3 & $\begin{array}{l}\text { Possibly a similar type although the dominant Carex } \\
\text { species was different. }\end{array}$ \\
\hline $\begin{array}{l}\text { Betula pumila - Salix spp. Rich } \\
\text { Boreal Fen Shrubland (Greenall } \\
\text { 1996) }\end{array}$ & 2 & $\begin{array}{l}\text { Likely a very similar type but no details were available } \\
\text { regarding floristics of this type. }\end{array}$ \\
\hline
\end{tabular}




\subsubsection{Salix planifolia / Calamagrostis canadensis Shrubland}

Flat-leaved Willow / Bluejoint Shrubland

This community was not common and was encountered only once in the North Buck Lake study area (Table 38). Sites were located in interdune depressional areas where the water table remains permanently near the ground surface. Flooding was likely to occur frequently and sites were very poorly drained with hydric moisture levels. Surface substrate cover was dominated by water (58\%) followed by organic matter $(40 \%)$ and decaying wood $(2 \%)$. Soils consist of a thick layer of Organic material and nutrient levels were eutrophic. Based on percent cover values the dominant plant and key indicator species of the community were Salix planifolia $(40 \%)$ and Calamagrostis canadensis $(40 \%)$. Other plant and moss species occurring at low percent cover include Salix myrtillifolia, Carex utriculata, other Carex spp. and Drepanocladus aduncus.

Class: Shrubland

Subclass: Deciduous Shrubland

Group: Cold-deciduous shrubland

Subgroup: Natural/Semi-natural cold-deciduous shrubland

Formation: Saturated cold-deciduous shrubland

Alliance: Salix planifolia Saturated Shrubland Alliance

Association: Salix planifolia - Calamagrostis canadensis Shrubland

Unique Identifier: $\mathrm{n} / \mathrm{a}$

Classification Confidence Level: 2 (Moderate) There was a relatively good correlation of plot data with the published and unpublished literature for the type. Appears to fit within the known geographical range.

Dominant Species: Salix planifolia, Calamagrostis canadensis

Co-Dominant Species: Salix myrtillifolia, Carex utriculata, Drepanocladus aduncus

Diagnostic Species: Salix planifolia, Calamagrostis canadensis

Table 38. Summary of plot data and descriptive statistics for the Salix planifolia / Calamagrostis canadensis community type $(\mathrm{n}=1)$.

\begin{tabular}{|c|c|c|c|}
\hline \multirow[b]{2}{*}{ Strata } & \multirow[b]{2}{*}{ Code } & \multirow[b]{2}{*}{ Species } & Plot \\
\hline & & & P59 \\
\hline S1 & SALIPLA & Salix planifolia & 40.0 \\
\hline G & CALACAN & Calamagrostis canadensis & 40.0 \\
\hline $\mathrm{E}$ & EPIPHYT & Epiphyte spp. & 25.0 \\
\hline S2 & SALIMYR & Salix myrtillifolia & 5.0 \\
\hline M & DREPADU & Drepanocladus aduncus & 3.0 \\
\hline G & CAREUTR & Carex utriculata & 3.0 \\
\hline
\end{tabular}

\begin{tabular}{|c|c|c|c|}
\hline \multirow[b]{2}{*}{ Strata } & \multirow[b]{2}{*}{ Code } & \multirow[b]{2}{*}{ Species } & \multirow{2}{*}{$\begin{array}{l}\text { Plot } \\
\text { P59 } \\
\end{array}$} \\
\hline & & & \\
\hline S2 & BETUPAP & Betula papyrifera & 0.1 \\
\hline G & CAREDIS & Carex disperma & 0.1 \\
\hline G & CAREAQU & Carex aquatilis & 0.1 \\
\hline S1 & SALISER & Salix serissima & 0.1 \\
\hline $\mathrm{H}$ & GALITRI & Galium trifidum & 0.1 \\
\hline
\end{tabular}

\section{Literature Review:}

Allen et al. (2003) reported that a Salix planifolia - Calamagrostis canadensis community type was present in the Fidler-Greywillow Provincial Park at Lake Athabasca. Here it formed a dense willow thicket adjacent a small creek. Raup and Argus (1982) reported a similar community that occurred near wet meadows in the Lake Athabasca area. Allen et al. (2002) reported a second similar type from the La Butte Creek Wildland Provincial Park located north of Lake Athabasca. This was described as a Salix bebbiana - S. planifolia - S. petiolaris / Carex atherodes - Calamagrostis canadensis community. 
Typically it surrounded large Carex atherodes meadows. Allen and Johnson (no date.) described a Salix planifolia - Salix petiolaris community type that occurred in the Richardson River Dunes Wildland Park. No details were provided for this type except that it formed a willow ring at edge of an old beaver pond. This community type also occurred in the Birch Mountains of northern Alberta (Unpublished plot data BM:04, 17a, 26a, 32, 72; pers. comm. Keith Ainsley 2005). Salix planifolia and Calamagrostis canadensis dominated this community, however, the dominant sedge species was Carex aquatilis instead of C. utriculata. This type was tentatively described as a Salix spp. / Calamagrostis canadensis community type.

Beckingham and Archibald (196) described a Salix spp. / Calamagrostis canadensis type (k2.3) in the boreal mixedwood. In descending order of dominance, important species include Salix spp., Calamagrostis canadensis, Drepanocladus spp., Myrica gale, Caltha palustris, and Menyanthes trifoliata. The main difference with the current type was the lack of Calamagrostis canadensis in the k2.3 community.

Thompson and Hansen (2002) described a Salix planifolia / Carex utriculata Habitat Type that was very similar to the current classification. This community was a minor type in the Lower Foothills Subregion and an incidental type outside the Mixedgrass Subregions. It was associated with meadows adjacent to lakes, streams, springs and other wet sites. These stands had higher plant diversity than the current classification but common dominant species include Salix planifolia, Calamagrostis canadensis, and Carex utriculata. Sites may be seasonally flooded and had very poorly drained soils that were permanently saturated.

The current classification appears to fit into the Salix planifolia Saturated Shrubland Alliance (A.3514) that was a recognised type in Manitoba (Midwestern Ecology Group: NatureServe 2004). NatureServe (2004) and Greenall (1996) list a Salix planifolia - Betula pumila var. glandulifera Shrubland (CEGL002529) that may be similar to the current classification. As indicated above, this type occurred in Manitoba but no details were available regarding floristics or site conditions for the type. Another community listed by NatureServe (2004) was the Salix planifolia - Calamagrostis canadensis Shrubland (CEGL001225). It was common in high-elevation mountain wetlands of Wyoming, Utah, and Colorado. Salix planifolia cover was typically $40 \%$ to $90 \%$ and associated willows include Salix brachycarpa and Salix wolfii. Calamagrostis canadensis dominated the herbaceous layer along with Carex spp. including Carex utriculata, Carex microptera, and Carex aquatilis. Forbs may include Caltha leptosepala, Cardamine cordifolia, Pedicularis groenlandica, and Mertensia ciliata. Similarity ratings for related plant community types are provided in Table 39. 
Table 39. Correlation table of plant community types with similarity ratings for the Salix planifolia / Calamagrostis canadensis type.

\begin{tabular}{|c|c|c|}
\hline Similar Types & $\begin{array}{l}\text { Similarity } \\
\text { Rating } \\
\end{array}$ & Comments \\
\hline $\begin{array}{l}\text { Salix planifolia - Calamagrostis } \\
\text { canadensis CT (Allen et al. 2003, } \\
\text { Raup and Argus 1982) }\end{array}$ & 1 & $\begin{array}{l}\text { No details regarding site conditions and CT composition. } \\
\text { Expected to be the same or a closely related type. }\end{array}$ \\
\hline $\begin{array}{l}\text { Salix bebbiana }- \text { S. planifolia - S. } \\
\text { petiolaris / Carex atherodes - } \\
\text { Calamagrostis canadensis CT (Allen } \\
\text { et al. 2002) }\end{array}$ & 3 & $\begin{array}{l}\text { No details regarding site conditions and CT composition } \\
\text { but appears to be a similar type although dominant } \\
\text { species were different. }\end{array}$ \\
\hline $\begin{array}{l}\text { Salix planifolia - Salix petiolaris CT } \\
\text { (Allen and Johnson no date) }\end{array}$ & 3 & $\begin{array}{l}\text { Possibly a similar type but no additional details were } \\
\text { available for review. }\end{array}$ \\
\hline $\begin{array}{l}\text { Salix spp. - Calamagrostis } \\
\text { canadensis CT (pers. comm. Keith } \\
\text { Ainsley 2005). }\end{array}$ & 1 & $\begin{array}{l}\text { Based on plot data this Birch Mountains CT appears to } \\
\text { be identical. }\end{array}$ \\
\hline $\begin{array}{l}\text { Salix spp. / Calamagrostis } \\
\text { canadensis CT (k2.3) (Beckingham } \\
\text { and Archibald 1996) }\end{array}$ & 3 & $\begin{array}{l}\text { Similar type but was void of Calamagrostis canadensis } \\
\text { cover and there are differences in other diagnostic } \\
\text { species. }\end{array}$ \\
\hline $\begin{array}{l}\text { Salix planifolia / Carex utriculata } \\
\text { Habitat Type (Thompson and Hansen } \\
\text { 2002) }\end{array}$ & 2 & $\begin{array}{l}\text { Shares same ecological niche in adjacent natural } \\
\text { subregions. Same alliance type as current classification } \\
\text { but has different prominence of the indicator species and } \\
\text { other dissimilarities in floristics. }\end{array}$ \\
\hline $\begin{array}{l}\text { Salix planifolia Saturated Shrubland } \\
\text { Alliance (A.3514) (NatureServe } \\
\text { 2004) }\end{array}$ & 1 & $\begin{array}{l}\text { No details provided regarding this alliance but it was } \\
\text { assumed that the current classification was part of this } \\
\text { alliance type. }\end{array}$ \\
\hline $\begin{array}{l}\text { Salix planifolia - Betula pumila var. } \\
\text { glandulifera Shrubland } \\
\text { (CEGL002529) (Greenall 1996, } \\
\text { NatureServe 2004) }\end{array}$ & 3 & $\begin{array}{l}\text { Dominant plant species was the same but further } \\
\text { assessment of similarity not possible without more } \\
\text { details on the floristics and ecological site } \\
\text { characteristics. }\end{array}$ \\
\hline $\begin{array}{l}\text { Salix planifolia - Calamagrostis } \\
\text { canadensis Shrubland } \\
\text { (CEGL001225) NatureServe (2004) }\end{array}$ & 3 & $\begin{array}{l}\text { Shares same dominant species and some of the co- } \\
\text { dominant species but otherwise floristics were dissimilar } \\
\text { due to geographical separation. }\end{array}$ \\
\hline
\end{tabular}




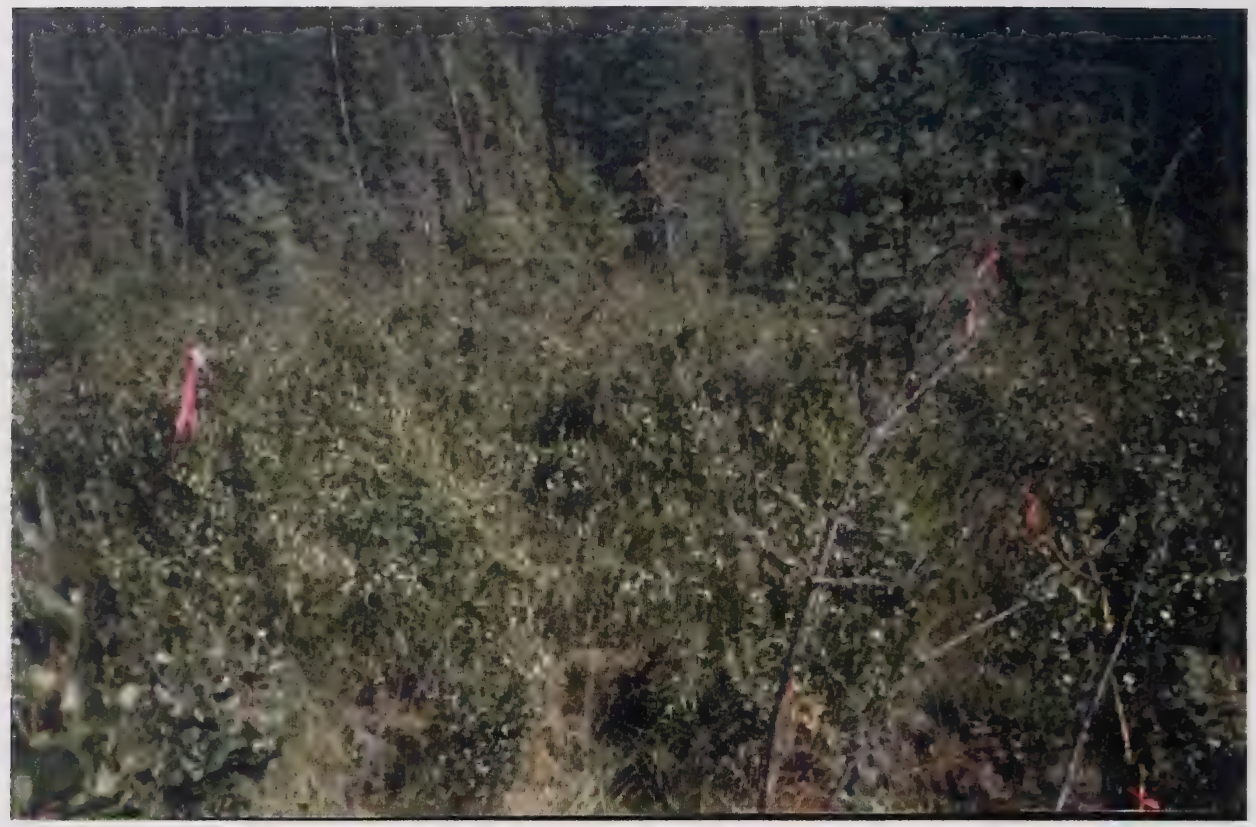

Plate 18. Betula pumila - (Salix spp.) / Carex diandra / Aulacomnium palustre Shrubland (P32).

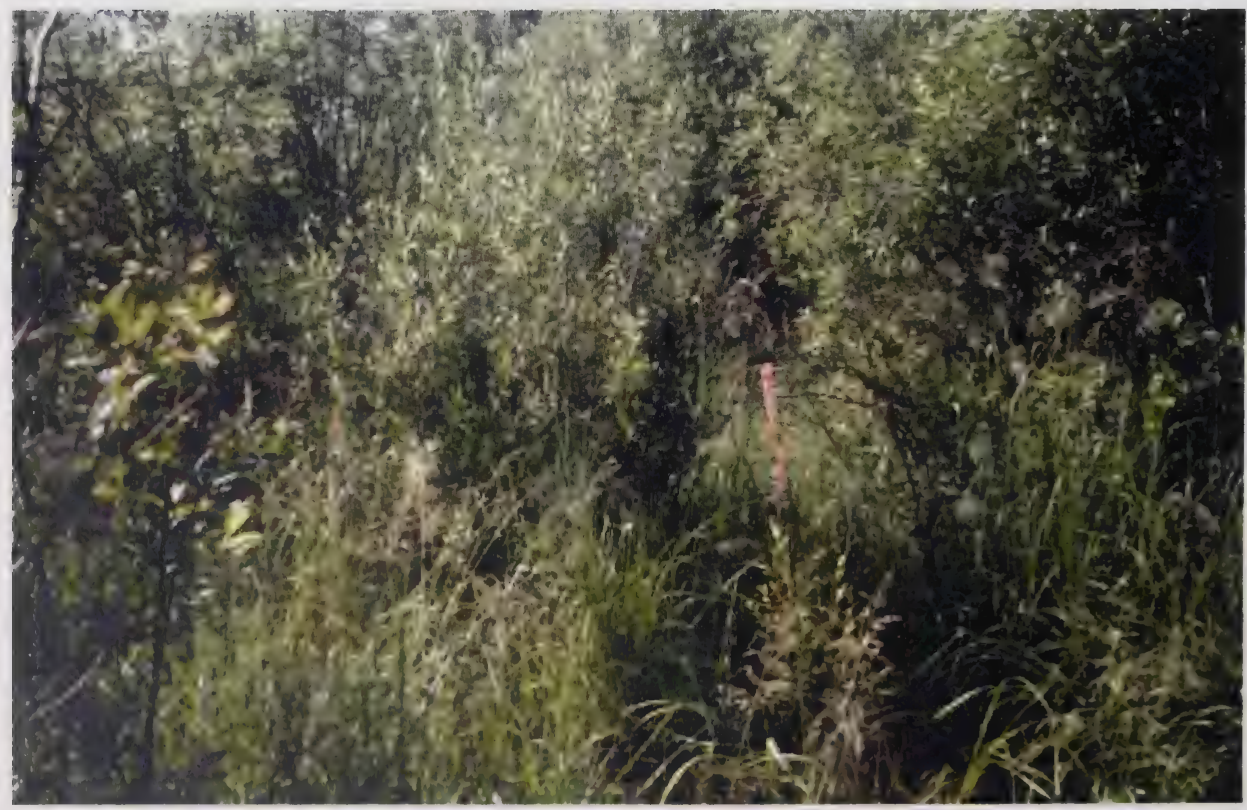

Plate 19. Salix planifolia - Calamagrostis canadensis Shrubland (P59). 


\subsubsection{Salix petiolaris / Carex diandra - Calamagrostis stricta Shrubland}

Basket Willow / Two-stamened Sedge - Narrow Reed Grass Shrubland

This community type occurred in interdune depressions on level sites where the water table remains permanently at the ground surface. It was not encountered in the North Buck Lake study area yet was quite common in the Holmes Crossing Sandhills Ecological Reserve where three (3) samples were completed (Table 40). Sites were frequently flooded and standing water was common. The very poorly to imperfectly drained Organic soils had hydric to hygric moisture levels and nutrient levels were mesotrophic. Surface substrate cover was primarily organic matter (79\% mean) with substantial areas of standing water ( $20 \%$ mean) and small amounts of decaying wood ( $1 \%$ mean). Salix petiolaris cover was approximately $14 \%$ ( 0.5 to $30 \%$ range) with generally lesser amounts of other willows including Salix pedicellaris, Salix planifolia, Salix candida, Salix bebbiana, and Salix pseudomonticola. The herb/graminoid was dominated by Carex diandra cover (37\%) and Calamagrostis stricta (11\%). Other graminoids may include Carex chordorrhiza, Agrostis scabra, Calamagrostis canadensis, Muhlenbergia glomerata, and Poa interior. The herb layer was sparse but included Potentilla norvegica, Potentilla palustris, Epilobium palustre, and Equisetum fluviatile. Although there was only trace amounts of Salix petiolaris cover at Plot \# 16 it was included in this grouping based on species constancy. Salix pedicellaris commonly occurred in association with $S$. petiolaris but it was the dominant willow species at this plot. Additional sampling may have resulted in the formation of a separate Salix pedicellaris dominated plant community type.

Class: Shrubland

Subclass: Deciduous Shrubland

Group: Cold-deciduous shrubland

Subgroup: Natural/Semi-natural cold-deciduous shrubland

Formation: Temporarily flooded cold-deciduous shrubland

Alliance: Salix petiolaris - Salix spp. Temporarily Flooded Shrubland Alliance

Association: Salix petiolaris / Carex diandra - Calamagrostis stricta Shrubland

Unique Identifier: $\mathrm{n} / \mathrm{a}$

Classification Confidence Level: 2 (Moderate) Moderately good correlation of plot data with the published literature for the type and occurs within the known geographical range.

Dominant Species: Salix petiolaris, Salix pedicellaris, Calamagrostis stricta, Carex diandra Co-Dominant Species: Salix candida, Salix planifolia, Carex chordorrhiza

Diagnostic Species: Salix petiolaris, Salix candida, Salix pedicellaris, Potentilla norvegica, Potentilla palustris, Carex diandra, Calamagrostis stricta, Agrostis scabra

\section{Literature Review:}

Thompson and Hansen (2002) described a Salix petiolaris / Carex atherodes Community Type that was a major community in the Central Parkland Subregion. This type occurred in sloughs, depressional wetlands and wet meadows. It often forms a narrow band of vegetation between open water and/or sedges, and drier wetland communities. Water tables were typically within $1 \mathrm{~m}$ of the ground surface throughout the growing season. Common species in the shrub layer included Salix petiolaris and Salix bebbiana, and common forbs included Potentilla norvegica, Geum macrophyllum, Potentilla norvegica, and Scutellaria galericulata. There were no species in common in the graminoid layer although sedges dominated both and species of the genus Poa were present in both as well.

NatureServe (2004) lists a Salix petiolaris - (Betula pumila) / Spartina pectinata - Carex pellita Shrubland (CEGL002434) that occurred in the aspen parkland region of the upper midwestern United States and Canada, particularly in southeastern Manitoba (Greenall 1996). This type occurred on poorly drained sites 
Table 40. Summary of plot data and descriptive statistics for the Salix petiolaris / Carex diandra Calamagrostis stricta community type $(\mathrm{n}=3)$.

\begin{tabular}{|c|c|c|c|c|c|c|c|c|c|}
\hline \multirow[b]{2}{*}{ Strata } & \multirow[b]{2}{*}{ Code } & \multirow[b]{2}{*}{ Species } & \multicolumn{3}{|c|}{ Plots } & \multirow[b]{2}{*}{ Mean } & \multirow[b]{2}{*}{ SE } & \multirow[b]{2}{*}{ Constancy } & \multirow[b]{2}{*}{ Prominence } \\
\hline & & & P13 & P16 & P31 & & & & \\
\hline G & CAREDIA & Carex diandra & 20.0 & 40.0 & 50.0 & 36.7 & 8.8 & 100.0 & 60.6 \\
\hline G & CALASTR & Calamagrostis stricta & 12.0 & 0.1 & 20.0 & 10.7 & 5.8 & 100.0 & 32.7 \\
\hline $\mathrm{S} 3$ & SALIPED & Salix pedicellaris & 2.0 & 15.0 & 0.0 & 5.7 & 4.7 & 66.7 & 19.4 \\
\hline SI & SALIPET & Salix petiolaris & 0.0 & 0.0 & 30.0 & 10.0 & 10.0 & 33.3 & 18.3 \\
\hline $\mathrm{S} 2$ & SALIPET & Salix petiolaris & 10.0 & 0.0 & 0.0 & 3.3 & 3.3 & 33.3 & 10.5 \\
\hline S3 & SALIPLA & Salix planifolia & 0.0 & 0.0 & 4.0 & 1.3 & 1.3 & 33.3 & 6.7 \\
\hline G & CARECHO & Carex chordorrhiza & 4.0 & 0.0 & 0.0 & 1.3 & 1.3 & 33.3 & 6.7 \\
\hline $\mathrm{S} 2$ & SALIPED & Salix pedicellaris & 0.0 & 0.0 & 3.0 & 1.0 & 1.0 & 33.3 & 5.8 \\
\hline $\mathrm{S} 2$ & SALICAN & Salix candida & 0.1 & 0.0 & 1.0 & 0.4 & 0.3 & 66.7 & 4.9 \\
\hline $\mathrm{S} 2$ & SALIPLA & Salix planifolia & 2.0 & 0.0 & 0.0 & 0.7 & 0.7 & 33.3 & 4.7 \\
\hline $\mathrm{E}$ & EPIPHYT & Epiphyte spp. & 0.0 & 0.0 & 1.0 & 0.3 & 0.3 & 33.3 & 3.3 \\
\hline S3 & SALIBEB & Salix bebbiana & 0.0 & 0.0 & 1.0 & 0.3 & 0.3 & 33.3 & 3.3 \\
\hline $\mathrm{H}$ & EPILPAL & Epilobium palustre & 0.0 & 0.5 & 0.0 & 0.2 & 0.2 & 33.3 & 2.4 \\
\hline S3 & SALIPET & Salix petiolaris & 0.0 & 0.5 & 0.0 & 0.2 & 0.2 & 33.3 & 2.4 \\
\hline $\mathrm{H}$ & EQUIFLU & Equisetum fluviatile & 0.0 & 0.5 & 0.0 & 0.2 & 0.2 & 33.3 & 2.4 \\
\hline $\mathrm{H}$ & POTENOR & Potentilla norvegica & 0.1 & 0.0 & 0.1 & 0.1 & 0.0 & 66.7 & 2.1 \\
\hline $\mathrm{H}$ & POTEPAL & Potentilla palustris & 0.1 & 0.0 & 0.1 & 0.1 & 0.0 & 66.7 & 2.1 \\
\hline $\mathrm{G}$ & AGROSCA & Agrostis scabra & 0.1 & 0.1 & 0.0 & 0.1 & 0.0 & 66.7 & 2.1 \\
\hline $\mathrm{S} 3$ & BETUPUM & Betula pumila & 0.0 & 0.0 & 0.1 & 0.0 & 0.0 & 33.3 & 1.1 \\
\hline G & CALACAN & Calamagrostis canadensis & 0.1 & 0.0 & 0.0 & 0.0 & 0.0 & 33.3 & 1.1 \\
\hline G & MUHLGLO & Muhlenbergia glomerata & 0.0 & 0.1 & 0.0 & 0.0 & 0.0 & 33.3 & 1.1 \\
\hline $\mathrm{S} 2$ & SALIBEB & Salix bebbiana & 0.1 & 0.0 & 0.0 & 0.0 & 0.0 & 33.3 & 1.1 \\
\hline $\mathrm{S} 2$ & BETUPUM & Betula pumila & 0.1 & 0.0 & 0.0 & 0.0 & 0.0 & 33.3 & 1.1 \\
\hline $\mathrm{G}$ & POAINTE & Poa interior & 0.0 & 0.0 & 0.1 & 0.0 & 0.0 & 33.3 & 1.1 \\
\hline S3 & POPUBAL & Populus balsamifera & 0.0 & 0.0 & 0.1 & 0.0 & 0.0 & 33.3 & 1.1 \\
\hline $\mathrm{H}$ & POLYAMP & Polygonum amphibium & 0.1 & 0.0 & 0.0 & 0.0 & 0.0 & 33.3 & 1.1 \\
\hline $\mathrm{H}$ & SCUTGAL & Scutellaria galericulata & 0.0 & 0.1 & 0.0 & 0.0 & 0.0 & 33.3 & 1.1 \\
\hline $\mathrm{S} 3$ & SALIPSE & Salix pseudomonticola & 0.0 & 0.0 & 0.1 & 0.0 & 0.0 & 33.3 & 1.1 \\
\hline $\mathrm{H}$ & GEUMMAC & Geum macrophyllum & 0.0 & 0.0 & 0.1 & 0.0 & 0.0 & 33.3 & 1.1 \\
\hline $\mathrm{H}$ & CICUMAC & Cicuta maculata & 0.0 & 0.1 & 0.0 & 0.0 & 0.0 & 33.3 & 1.1 \\
\hline $\mathrm{S} 2$ & BETUPAP & Betula papyrifera & 0.0 & 0.0 & 0.1 & 0.0 & 0.0 & 33.3 & 1.1 \\
\hline
\end{tabular}

with a range of soil textures including loamy fine sand to sandy clay loam. Populus tremuloides and Populus balsamifera saplings or small groves may be present. Dominant shrubs include Dasiphora fruticosa spp. floribunda (= Pentaphylloides floribunda), Salix discolor, Salix petiolaris (= Salix gracilis), and on some sites Betula pumila and Spiraea alba. Important grasses include Spartina pectinata, Calamagrostis stricta, Calamagrostis canadensis, Andropogon gerardii, and Muhlenbergia richardsonis. Common sedges include Carex buxbaumii, Carex pellita (= Carex lanuginosa), Carex sartwellii, and Carex tetanica. Commonly there was moderate cover of typical wet prairie forbs. Similarity ratings for related plant community types are provided in Table 41. 
Table 41. Correlation table of plant community types with similarity ratings for the Salix petiolaris / Carex diandra - Calamagrostis stricta type.

\begin{tabular}{||l|c|l||}
\hline \multicolumn{1}{|c|}{ Similar Types } & $\begin{array}{c}\text { Similarity } \\
\text { Rating }\end{array}$ & \multicolumn{1}{c|}{ Comments } \\
\hline \hline $\begin{array}{l}\text { Salix petiolaris / Carex atherodes CT } \\
\text { (Thompson and Hansen 2002) }\end{array}$ & 2 & $\begin{array}{l}\text { This was a related type of the Central Parkland, } \\
\text { Mixedgrass and Dry Mixedgrass Subregions. It occupies } \\
\text { similar ecological niches but has significant differences } \\
\text { in floristics. }\end{array}$ \\
\hline $\begin{array}{l}\text { Salix petiolaris - (Betula pumila)/ } \\
\text { Spartina pectinata - Carex pellita } \\
\text { Shrubland (CEGL002434) } \\
\text { NatureServe (2004) }\end{array}$ & 3 & $\begin{array}{l}\text { Although this was a Salix petiolaris type that occurred in } \\
\text { the central parkland there were significant differences in } \\
\text { community structure and floristics. }\end{array}$ \\
\hline
\end{tabular}

\subsubsection{Alnus viridis spp. crispa - Prunus pensylvanica / Aralia nudicaulis Shrubland Green Alder - Pin Cherry / Sarsaparilla Shrubland}

Small patches of alder were observed in the Holmes Crossing Sandhills Ecological Reserve and North Buck Lake study areas. Often these occurred as irregular shaped communities in small forest openings. The one plot completed in the North Buck Lake study area occurred on a gentle upper slope (4\%slope gradient) adjacent to a stand of aspen and jack pine. Soils were well-drained fine sands with submesic moisture levels and a mesotrophic nutrient regime. The surface substrate cover was predominantly organic matter (95\%) with some decaying wood $3 \%$, and exposed mineral soil at $2 \%$. The shrub layer cover was very dense and was dominated by Alnus viridis (60\%) and Prunus pensylvanica (15\%) (Table 42). Other species that were co-dominant in the S1 shrub layer included Amelanchier alnifolia, Picea glauca, and Prunus virginiana. Vaccinium myrtilloides and Rubus idaeus were also present. The herb layer was clearly dominated by Aralia nudicaulis (30\% cover) with only trace amounts of Epilobium angustifolium, Fragaria virginiana, Equisetum laevigatum, Campanula rotundifolia and other species.

Class: Shrubland

Subclass: Deciduous Shrubland

Group: Cold-deciduous shrubland

Subgroup: Natural/Semi-natural cold-deciduous shrubland

Formation: Subalpine or subpolar cold-deciduous shrubland

Alliance: Alnus viridis spp. crispa / Carex pensylvanica Shrubland

Association: Alnus viridis spp. crispa - Prunus pensylvanica / Aralia nudicaulis Shrubland

Unique Identifier: $\mathrm{n} / \mathrm{a}$

Classification Confidence Level: 3 (Weak) This community type was not well defined by this study and only one plot was completed. There were reports of similar types noted in the literature review and the geographical range of this type was unknown.

Dominant Species: Alnus viridis, Prunus pensylvanica, Vaccinium myrtilloides, Aralia nudicaulis Co-Dominant Species: Amelanchier alnifolia, Picea glauca, Prunus virginiana, Rubus idaeus Diagnostic Species: Alnus viridis, Prunus pensylvanica, Vaccinium myrtilloides, Aralia nudicaulis 
Table 42. Summary of plot data and descriptive statistics for the Alnus viridis spp. crispa - Prunus pensylvanica / Aralia nudicaulis community type $(\mathrm{n}=1)$.

\begin{tabular}{|c|c|c|c|c|c|c|c|}
\hline \multirow[b]{2}{*}{ Strata } & \multirow[b]{2}{*}{ Code } & \multirow[b]{2}{*}{ Species } & \multirow{2}{*}{$\begin{array}{l}\text { Plot } \\
\text { P22 } \\
\end{array}$} & \multirow[b]{2}{*}{ Strata } & \multirow[b]{2}{*}{ Code } & \multirow[b]{2}{*}{ Species } & \multirow{2}{*}{$\begin{array}{l}\text { Plot } \\
\text { P22 }\end{array}$} \\
\hline & & & & & & & \\
\hline S1 & ALNUVIR & Alnus viridis & 60.0 & $\mathrm{H}$ & EPILANG & $\begin{array}{l}\text { Epilobium } \\
\text { angustifolium }\end{array}$ & 0.1 \\
\hline $\mathrm{H}$ & ARALNUD & Aralia nudicaulis & 30.0 & $\mathrm{H}$ & FRAGVIR & Fragaria virginiana & 0.1 \\
\hline S3 & VACCMYR & Vaccinium myrtilloides & 20.0 & $\mathrm{H}$ & EQUILAE & Equisetum laevigatum & 0.1 \\
\hline $\mathrm{S} 1$ & PRUNPEN & Prunus pensylvanica & 15.0 & $\mathrm{~S} 1$ & SALIBEB & Salix bebbiana & 0.1 \\
\hline $\mathrm{S} 2$ & RUBUIDA & Rubus idaeus & 10.0 & $\mathrm{H}$ & CAMPROT & Campanula rotundifolia & 0.1 \\
\hline $\mathrm{S} 1$ & AMELALN & Amelanchier alnifolia & 6.0 & $\mathrm{H}$ & ANEMMUL & Anemone multifida & 0.1 \\
\hline $\mathrm{S} 2$ & PRUNVIR & Prunus virginiana & 4.0 & G & SCHIPUR & $\begin{array}{l}\text { Schizachne } \\
\text { purpurascens }\end{array}$ & 0.1 \\
\hline S1 & PICEGLA & Picea glauca & 2.0 & M & MOSSES\$\$ & Moss spp. & 0.1 \\
\hline G & CARESIC & Carex siccata & 1.0 & G & ELYMINN & Leymus innovatus & 0.1 \\
\hline S3 & ROSAACI & Rosa acicularis & 1.0 & $\mathrm{H}$ & VIOLREN & Viola renifolia & 0.1 \\
\hline $\mathrm{H}$ & GALIBOR & Galium boreale & 0.1 & $\mathrm{H}$ & PYROCHL & Pyrola chlorantha & 0.1 \\
\hline S3 & VACCVIT & Vaccinium vitis-idaea & 0.1 & & & & \\
\hline
\end{tabular}

\section{Literature Review:}

Nelson et al. (1989) described a Dry Meadow Community Type for Holmes Crossing that occured on steep south-facing dune slopes that had rapidly drained soils and received intense insolation. The shrub layer was open with only $5 \%$ total cover consisting primarily of Alnus viridis spp. crispa ( $2 \%$ cover). Important species in the understorey were Smilacina stellata (20\%), Arctostaphylos uva-ursi (5\%), and Solidago multiradiata (5\%). Also occurring in the herb/graminoid layer was Artemisia campestris, Anemone multifida, Carex spp., Elymus trachycaulus and Oryzopsis pungens. NatureServe (2004) listed no similar types. Similarity ratings for related plant community types are provided in Table 43.

Table 43. Correlation table of plant community types with similarity ratings for the Alnus viridis spp. crispa - Prunus pensylvanica / Aralia nudicaulis type.

\begin{tabular}{|c|c|l||}
\hline Similar Types & $\begin{array}{c}\text { Similarity } \\
\text { Rating }\end{array}$ & \multicolumn{1}{c|}{ Comments } \\
\hline \hline Dry Meadow CT (Nelson et al. 1989) & 3 & $\begin{array}{l}\text { This was a drier more open plant community type with a } \\
\text { quite different species composition. }\end{array}$ \\
\hline
\end{tabular}




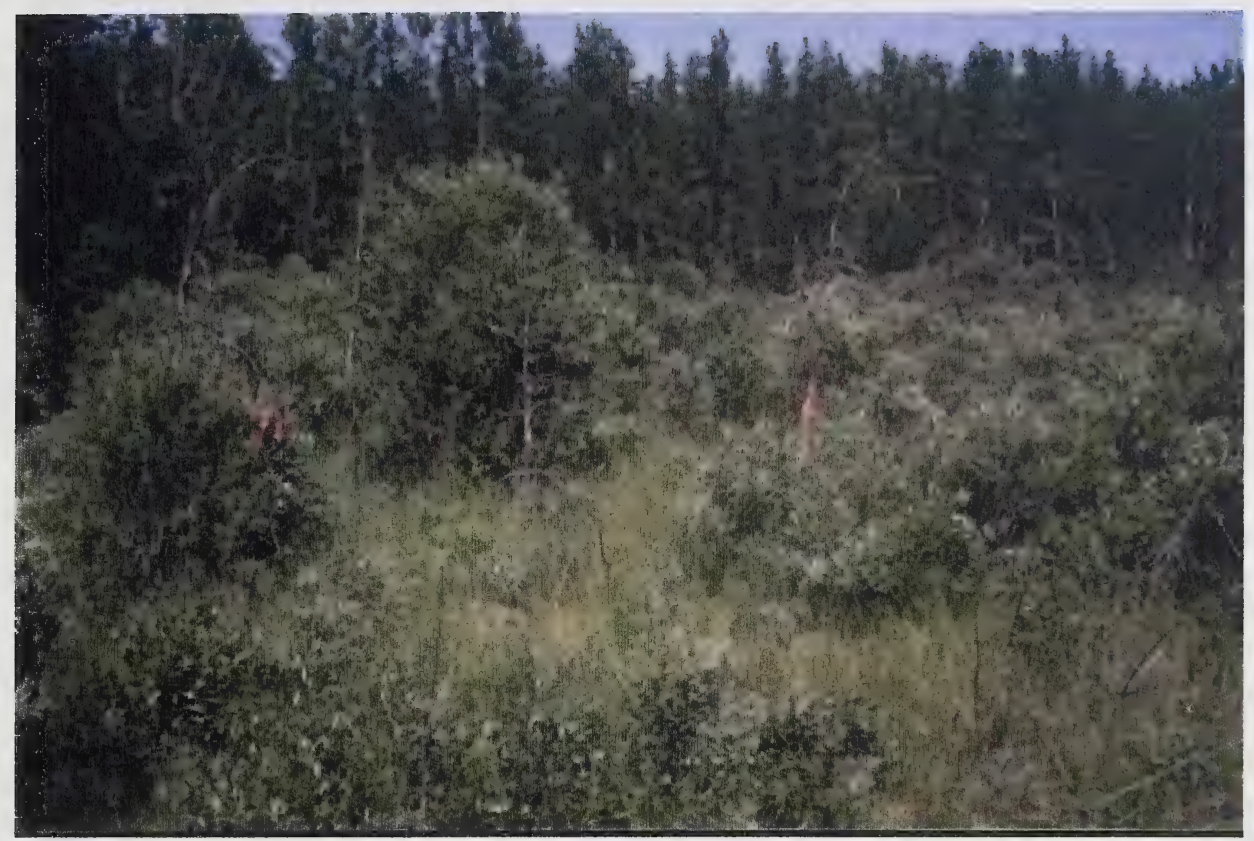

Plate 20. Salix petiolaris / Carex diandra - Calamagrostis stricta Shrubland (P31).

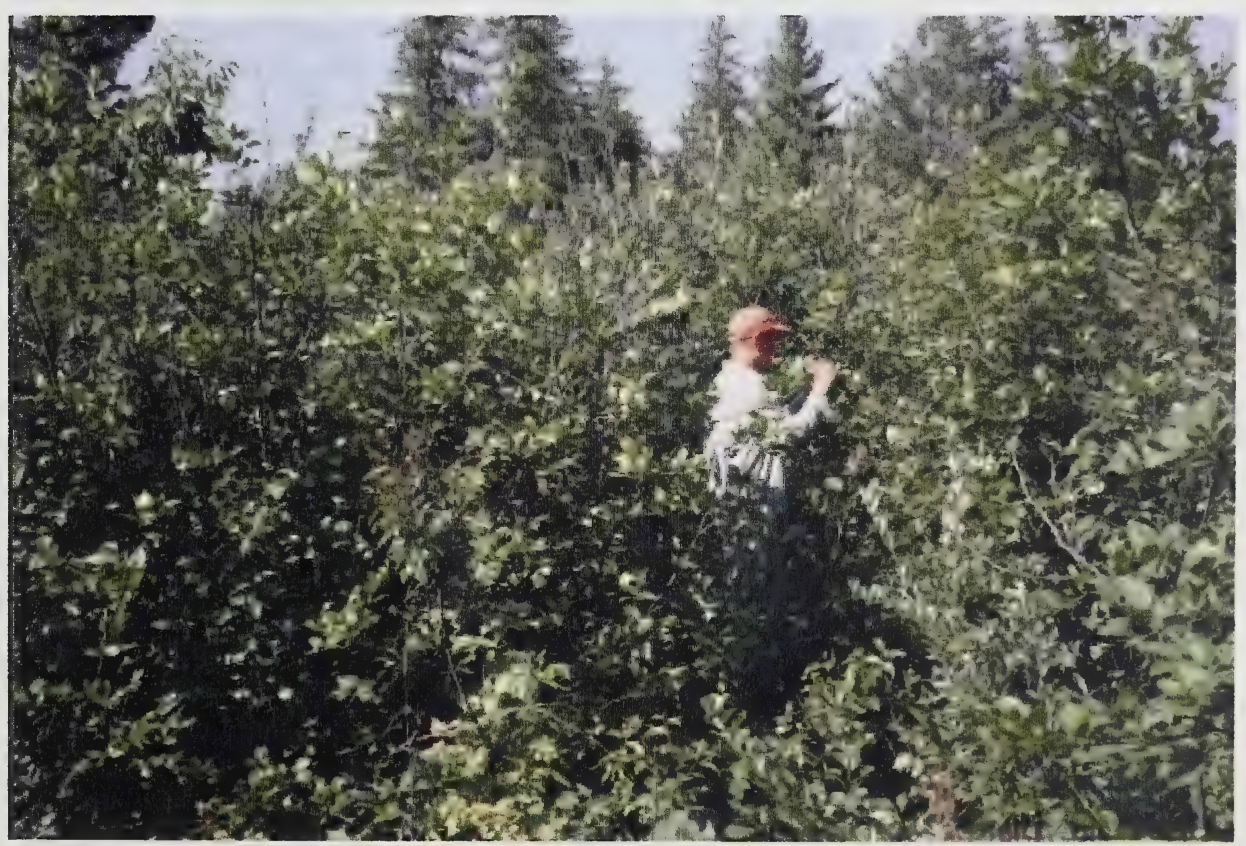

Plate 21. Alnus viridis spp. crispa - Prunus pensylvanica / Aralia nudicaulis Shrubland (P22). 


\subsubsection{Amelanchier alnifolia / Arctostaphylos uva-ursi / Oryzopsis pungens Dwarf-shrubland}

Saskatoon / Common Bearberry / Northern Rice Grass Dwarf-shrubland

This dwarf-shrubland community was relatively common in the Holmes Crossing Sandhills Ecological Reserve where five (5) plots were completed (Table 44). It was encountered less frequently in the North Buck Lake study area and one (1) plot was completed there. Sites were typically convex in profile and located on upper slopes and less frequently on mid-slope and crest positions. The mean slope gradient of the sites sampled was $24 \%$ ranging between $8 \%$ and $40 \%$. Aspects were also variable but were predominately southeast to southwest and moderate levels of insolation. Soils were fine sands, which were rapidly to well drained with subxeric to submesic moisture levels. The soil nutrient regime was mesotrophic. Surface substrate cover was mainly organic matter ( $86 \%$ mean) and exposed soil (13\% mean) with a trace of decaying wood. Arctostaphylos uva-ursi cover (35\% mean) dominates this community. Other important species include Prunus virginiana (4\%), Amelanchier alnifolia (2\%), Oryzopsis pungens (6\%), Aster laevis, Galium boreale, Solidago spathulata, Carex siccata, Festuca saximontana, Astragalus striatus, and Elymus trachycaulus.

Class: Dwarf-shrubland

Subclass: Evergreen dwarf-shrubland

Group: Needle-leaved or microphyllous evergreen dwarf-shrubland

Subgroup: Natural/Semi-natural needle-leaved or microphyllous evergreen dwarf-shrubland

Formation: Creeping or matted needle-leaved or microphyllous evergreen dwarf-shrubland

Alliance: Arctostaphylos uva-ursi Dwarf-shrubland Alliance

Association: Amelanchier alnifolia / Arctostaphylos uva-ursi / Oryzopsis pungens Dwarf-shrubland Unique Identifier: Listed in Alberta as CEAB000029.

Classification Confidence Level: 1 (Strong) This type was relatively common in both study areas and a total of six plots were completed. It was a reported type and was known to occur in the Dry Mixedwood Natural Subregion.

\section{Dominant Species: Arctostaphylos uva-ursi, Oryzopsis pungens}

Co-Dominant Species: Amelanchier alnifolia, Prunus virginiana, Astragalus striatus, Galium boreale, Solidago spathulata, Elymus trachycaulus, Carex siccata

Diagnostic Species: Amelanchier alnifolia, Arctostaphylos uva-ursi, Aster laevis, Galium boreale, Solidago spathulata, Carex siccata, Festuca saximontana, Oryzopsis pungens

\section{Literature Review:}

Allen (2004) lists an Amelanchier alnifolia / Arctostaphylos uva-ursi / Oryzopsis pungens community type (CEAB000029) that occurred on level, upland pockets in the Dry Mixedwood Natural Subregion. Stands were usually small and surrounded by jack pine or aspen stands. This community was the equivalent of the DMA7 type identified in Willoughby et al. (1997) and was provincially ranked S2S3. Timoney and Robinson (1998) noted that Oryzopsis pungens grasslands occurred in Ft. Assiniboine Sandhills Wildland Park. They referred to a Pinus banksiana / Arctostaphylos uva-ursi / Oryzopsis pungens community type. This community generally occurred as a savannah or parkland mosaic with dry jack pine forest.

Allen et al. (2002) reported an Amelanchier alnifolia / Arctostaphylos uva-ursi / Oryzopsis pungens community type that occurred in the La Butte Creek Wildland Provincial Park located north of Lake Athabasca. Ground cover of this type was very similar to the current type. Amelanchier alnifolia, Arctostaphylos uva-ursi, and Oryzopsis pungens occurred at trace, $50 \%$ and $25 \%$ ground cover, respectively. There was generally a good fit of species between the current type and this community type. 
Table 44. Summary of plot data and descriptive statistics for the Amelanchier alnifolia / Arctostaphylos uva-ursi / Oryzopsis pungens community type $(\mathrm{n}=6)$.

\begin{tabular}{|c|c|c|c|c|c|c|c|c|c|c|c|c|}
\hline \multirow[b]{2}{*}{ Strata } & \multirow[b]{2}{*}{ Code } & \multirow[b]{2}{*}{ Species } & \multicolumn{6}{|c|}{ Plot } & \multirow[b]{2}{*}{ Mean } & \multirow[b]{2}{*}{ SE } & \multirow[b]{2}{*}{ Constancy } & \multirow[b]{2}{*}{ Prominence } \\
\hline & & & P02 & P04 & P10 & P14 & $\mathbf{P 2 0}$ & P57 & & & & \\
\hline S3 & ARCTUVA & Arctostaphylos uva-ursi & 30.0 & 15.0 & 25.0 & 37.0 & 30.0 & 70.0 & 34.5 & 7.7 & 100.0 & 58.7 \\
\hline $\mathrm{G}$ & ORYZPUN & Oryzopsis pungens & 3.0 & 2.0 & 9.0 & 12.0 & 4.0 & 4.0 & 5.7 & 1.6 & 100.0 & 23.8 \\
\hline $\mathrm{H}$ & SOLISPA & Solidago spathulata & 0.0 & 10.0 & 4.0 & 7.0 & 5.0 & 0.0 & 4.3 & 1.6 & 66.7 & 17.0 \\
\hline G & CARESIC & Carex siccata & 0.0 & 0.1 & 15.0 & 8.0 & 0.0 & 0.5 & 3.9 & 2.6 & 66.7 & 16.2 \\
\hline S3 & PRUNVIR & Prunus virginiana & 0.0 & 0.0 & 6.0 & 12.0 & 7.0 & 0.0 & 4.2 & 2.0 & 50.0 & 14.4 \\
\hline S3 & AMELALN & Amelanchier alnifolia & 0.0 & 3.0 & 2.0 & 5.0 & 3.0 & 0.5 & 2.3 & 0.8 & 83.3 & 13.7 \\
\hline G & ELYMTRA & Elymus trachycaulus & 0.5 & 2.0 & 4.0 & 1.0 & 3.0 & 0.0 & 1.8 & 0.6 & 83.3 & 12.1 \\
\hline $\mathrm{H}$ & ASTRSTR & Astragalus striatus & 0.0 & 0.0 & 4.0 & 9.0 & 2.0 & 0.0 & 2.5 & 1.5 & 50.0 & 11.2 \\
\hline $\mathrm{H}$ & GALIBOR & Galium boreale & 0.5 & 1.0 & 3.0 & 1.0 & 2.0 & 0.0 & 1.3 & 0.4 & 83.3 & 10.2 \\
\hline $\mathrm{H}$ & ASTELAE & Aster laevis & 2.0 & 3.0 & 2.0 & 0.0 & 0.5 & 0.0 & 1.3 & 0.5 & 66.7 & 9.1 \\
\hline $\mathrm{H}$ & ARTECAM & Artemisia campestris & 0.0 & 1.0 & 0.5 & 2.0 & 2.0 & 0.1 & 0.9 & 0.4 & 83.3 & 8.8 \\
\hline G & CAREUMB & Carex umbellata & 0.0 & 1.0 & 0.5 & 3.0 & 2.0 & 0.0 & 1.1 & 0.5 & 66.7 & 8.5 \\
\hline G & FESTSAX & Festuca saximontana & 0.0 & 0.5 & 0.5 & 0.0 & 3.0 & 2.0 & 1.0 & 0.5 & 66.7 & 8.2 \\
\hline S3 & ROSAACI & Rosa acicularis & 0.0 & 0.0 & 0.0 & 5.0 & 2.0 & 0.1 & 1.2 & 0.8 & 50.0 & 7.7 \\
\hline $\mathrm{H}$ & FRAGVIR & Fragaria virginiana & 0.0 & 0.0 & 3.0 & 2.0 & 2.0 & 0.0 & 1.2 & 0.5 & 50.0 & 7.6 \\
\hline $\mathrm{L}$ & CLADMIT & Cladina mitis & 0.0 & 0.0 & 0.0 & 0.0 & 2.0 & 8.0 & 1.7 & 1.3 & 33.3 & 7.5 \\
\hline $\mathrm{L}$ & CLADRAN & Cladina rangiferina & 20.0 & 0.0 & 0.0 & 0.0 & 0.0 & 0.0 & 3.3 & 3.3 & 16.7 & 7.5 \\
\hline $\mathrm{H}$ & LATHOCH & Lathyrus ochroleucus & 2.0 & 2.0 & 0.0 & 2.0 & 0.0 & 0.0 & 1.0 & 0.4 & 50.0 & 7.1 \\
\hline $\mathrm{H}$ & MAIACAN & Maianthemum canadense & 2.0 & 0.0 & 0.0 & 0.0 & 0.0 & 2.0 & 0.7 & 0.4 & 33.3 & 4.7 \\
\hline G & CAREPEN & Carex pensylvanica & 0.0 & 0.0 & 0.0 & 0.0 & 8.0 & 0.0 & 1.3 & 1.3 & 16.7 & 4.7 \\
\hline $\mathrm{H}$ & APOCAND & Apocynum androsaemifolium & 0.0 & 6.0 & 0.0 & 0.0 & 0.0 & 0.0 & 1.0 & 1.0 & 16.7 & 4.1 \\
\hline S3 & SYMPOCC & Symphoricarpos occidentalis & 0.0 & 0.0 & 0.5 & 2.0 & 0.0 & 0.0 & 0.4 & 0.3 & 33.3 & 3.7 \\
\hline $\mathrm{H}$ & SMILSTE & Smilacina stellata & 0.1 & 0.0 & 0.0 & 0.0 & 1.0 & 0.0 & 0.2 & 0.2 & 33.3 & 2.5 \\
\hline $\mathrm{H}$ & EPILANG & Epilobium angustifolium & 0.0 & 0.0 & 0.0 & 0.0 & 0.0 & 2.0 & 0.3 & 0.3 & 16.7 & 2.4 \\
\hline $\mathrm{H}$ & SELADEN & Selaginella densa & 0.0 & 0.0 & 0.0 & 2.0 & 0.0 & 0.0 & 0.3 & 0.3 & 16.7 & 2.4 \\
\hline S1 & AMELALN & Amelanchier alnifolia & 2.0 & 0.0 & 0.0 & 0.0 & 0.0 & 0.0 & 0.3 & 0.3 & 16.7 & 2.4 \\
\hline S2 & PRUNPEN & Prunus pensylvanica & 2.0 & 0.0 & 0.0 & 0.0 & 0.0 & 0.0 & 0.3 & 0.3 & 16.7 & 2.4 \\
\hline S2 & AMELALN & Amelanchier alnifolia & 2.0 & 0.0 & 0.0 & 0.0 & 0.0 & 0.0 & 0.3 & 0.3 & 16.7 & 2.4 \\
\hline $\mathrm{H}$ & SOLIMIS & Solidago missouriensis & 0.5 & 0.0 & 0.5 & 0.0 & 0.0 & 0.0 & 0.2 & 0.1 & 33.3 & 2.4 \\
\hline $\mathrm{L}$ & CLADONI & Cladonia spp. & 0.0 & 0.0 & 0.0 & 1.0 & 0.0 & 0.0 & 0.2 & 0.2 & 16.7 & 1.7 \\
\hline M & POLYPIL & Polytrichum piliferum & 0.0 & 0.0 & 0.0 & 0.0 & 0.0 & 1.0 & 0.2 & 0.2 & 16.7 & 1.7 \\
\hline $\mathrm{H}$ & LILIPHI & Lilium philadelphicum & 0.0 & 0.5 & 0.0 & 0.0 & 0.0 & 0.0 & 0.1 & 0.1 & 16.7 & 1.2 \\
\hline $\mathrm{H}$ & EQUILAE & Equisetum laevigatum & 0.0 & 0.0 & 0.5 & 0.0 & 0.0 & 0.0 & 0.1 & 0.1 & 16.7 & 1.2 \\
\hline $\mathrm{H}$ & ANDRSEP & Androsace septentrionalis & 0.0 & 0.5 & 0.0 & 0.0 & 0.0 & 0.0 & 0.1 & 0.1 & 16.7 & 1.2 \\
\hline $\mathrm{H}$ & TRIEBOR & Trientalis borealis & 0.0 & 0.0 & 0.0 & 0.0 & 0.0 & 0.5 & 0.1 & 0.1 & 16.7 & 1.2 \\
\hline S3 & VACCMYR & Vaccinium myrtilloides & 0.0 & 0.0 & 0.0 & 0.0 & 0.0 & 0.5 & 0.1 & 0.1 & 16.7 & 1.2 \\
\hline S3 & VACCVIT & Vaccinium vitis-idaea & 0.5 & 0.0 & 0.0 & 0.0 & 0.0 & 0.0 & 0.1 & 0.1 & 16.7 & 1.2 \\
\hline S2 & ROSAACI & Rosa acicularis & 0.5 & 0.0 & 0.0 & 0.0 & 0.0 & 0.0 & 0.1 & 0.1 & 16.7 & 1.2 \\
\hline G & CAREX\$\$\$ & Carex spp & 0.1 & 0.1 & 0.0 & 0.0 & 0.0 & 0.0 & 0.0 & 0.0 & 33.3 & 1.1 \\
\hline $\mathrm{L}$ & PELTMAL & Peltigera malacea & 0.0 & 0.0 & 0.0 & 0.0 & 0.0 & 0.1 & 0.0 & 0.0 & 16.7 & 0.5 \\
\hline $\mathrm{H}$ & VICIAME & Vicia americana & 0.1 & 0.0 & 0.0 & 0.0 & 0.0 & 0.0 & 0.0 & 0.0 & 16.7 & 0.5 \\
\hline $\mathrm{H}$ & THALVEN & Thalictrum venulosum & 0.0 & 0.0 & 0.1 & 0.0 & 0.0 & 0.0 & 0.0 & 0.0 & 16.7 & 0.5 \\
\hline $\mathrm{L}$ & PELTCAN & Peltigera canina & 0.1 & 0.0 & 0.0 & 0.0 & 0.0 & 0.0 & 0.0 & 0.0 & 16.7 & 0.5 \\
\hline S2 & PRUNVIR & Prunus virginiana & 0.1 & 0.0 & 0.0 & 0.0 & 0.0 & 0.0 & 0.0 & 0.0 & 16.7 & 0.5 \\
\hline $\mathrm{H}$ & CAMPROT & Campanula rotundifolia & 0.0 & 0.1 & 0.0 & 0.0 & 0.0 & 0.0 & 0.0 & 0.0 & 16.7 & 0.5 \\
\hline G & AGROSCA & Agrostis scabra & 0.0 & 0.0 & 0.0 & 0.0 & 0.0 & 0.1 & 0.0 & 0.0 & 16.7 & 0.5 \\
\hline $\mathrm{H}$ & ACHIMIL & Achillea millefolium & 0.1 & 0.0 & 0.0 & 0.0 & 0.0 & 0.0 & 0.0 & 0.0 & 16.7 & 0.5 \\
\hline M & POLYTRI & Polytrichum spp. & 0.1 & 0.0 & 0.0 & 0.0 & 0.0 & 0.0 & 0.0 & 0.0 & 16.7 & 0.5 \\
\hline $\mathrm{H}$ & MELALIN & Medicago lupulina & 0.0 & 0.0 & 0.0 & 0.0 & 0.0 & 0.1 & 0.0 & 0.0 & 16.7 & 0.5 \\
\hline $\mathrm{H}$ & ERIGGLA & Erigeron glabellus & 0.0 & 0.1 & 0.0 & 0.0 & 0.0 & 0.0 & 0.0 & 0.0 & 16.7 & 0.5 \\
\hline
\end{tabular}


Wheatley and Bentz (2002) described an Arctostaphylos uva-ursi Dwarf-Shrubland Alliance type for the Central Parkland Natural Subregion. It occurred on sandy upland plains on poorly developed soils that were rapidly drained with xeric moisture conditions and submesotrophic nutrients levels. Arctostaphylos uva-ursi was the dominant plant and associates include Juniperus horizontalis, Heterotheca villosa, Solidago missouriensis, Artemisia frigida, Artemisia campestris, Calamovilfa longifolia and Agropyron dasystachyum.

Wildlands Ecological Consulting Ltd. (2004) described an Arctostaphylos uva-ursi Dwarf-shrubland that occupied a similar ecological niche in the Dry Mixedgrass and Mixedgrass Natural Subregions. Arctostaphylos uva-ursi cover formed dense mats with $63 \%$ ground cover. Other plant species with relatively high percent cover included Juniperus communis, Hedysarum boreale, and Hymenoxys acaulis. Other important species were Juniperus horizontalis, Pascopyrum smithii, Koeleria macrantha, Eriogonum flavum, Achillea millefolium, and Comandra umbeliatum.

NatureServe describes an Arctostaphylos uva-ursi / Solidago multiradiata Dwarf-shrubland type (CEGL005832). This community potentially occurred in Alberta and was common in Glacier National Park of Montana. It occurred in the subalpine and lower alpine areas often associated with Pinus albicaulis stands or krummholz patches of Abies lasiocarpa and Pinus flexilis. Arctostaphylos uva-ursi was variable ranging between $10 \%$ and $75 \%$ cover. Other constant species include Dasiphora fruticosa spp. floribunda and Juniperus communis. Graminoids cover included trace amounts of Calamagrostis koelerioides, Festuca idahoensis, and Festuca campestris. Forbs with high constancy include Solidago multiradiata, Hedysarum sulphurescens, Minuartia obtusiloba (= Arenaria obtusiloba), Potentilla diversifolia, Campanula rotundifolia, Galium boreale, Cerastium arvense, Achillea millefolium, Pulsatilla patens spp. multifida (= Anemone patens), Bupleurum americanum, Sedum lanceolatum, and Antennaria umbrinella. Similarity ratings for related plant community types are provided in Table 45 .

Table 45. Correlation table of plant community types with similarity ratings for the Amelanchier alnifolia / Arctostaphylos uva-ursi / Oryzopsis pungens type.

\begin{tabular}{||l|c|l||}
\hline \multicolumn{1}{|c|}{ Similar Types } & $\begin{array}{c}\text { Similarity } \\
\text { Rating }\end{array}$ & \multicolumn{1}{c||}{ Comments } \\
\hline $\begin{array}{l}\text { Amelanchier alnifolia / Arctostaphylos } \\
\text { uva-ursi / Oryzopsis pungens CT } \\
\text { (CEAB000029) (Willoughby } \text { et al. } \\
\text { 1997, Allen 2004) }\end{array}$ & 1 & $\begin{array}{l}\text { Based on dominant species this was a very similar } \\
\text { community type that was found in the Dry Mixedwood } \\
\text { Natural Subregion. }\end{array}$ \\
\hline $\begin{array}{l}\text { Amelanchier alnifolia / Arctostaphylos } \\
\text { uva-ursi / Oryzopsis pungens CT } \\
\text { (Allen } \text { et al. 2002) }\end{array}$ & $1(2)$ & $\begin{array}{l}\text { Appears to be a very similar type but it was reported to } \\
\text { occur on bedrock outcrops occupying similar sites. }\end{array}$ \\
\hline $\begin{array}{l}\text { Pinus banksiana / Arctostaphylos uva- } \\
\text { ursi / Oryzopsis pungens CT (Timoney } \\
\text { and Robinson 1998) }\end{array}$ & 2 & $\begin{array}{l}\text { The grassland portion of this community mosaic was } \\
\text { likely equivalent to the current type. However, no } \\
\text { details were provided on species composition and } \\
\text { percent covers. }\end{array}$ \\
\hline $\begin{array}{l}\text { Arctostaphylos uva-ursi Dwarf- } \\
\text { Shrubland Alliance (Wheatley and } \\
\text { Bentz 2002) }\end{array}$ & 2 & $\begin{array}{l}\text { Occurred in the parkland on sandy sites and has very } \\
\text { similar species composition. }\end{array}$ \\
\hline $\begin{array}{l}\text { Arctostaphylos uva-ursi Dwarf- } \\
\text { shrubland (Wildlands Ecological } \\
\text { Consulting Ltd. 2004) }\end{array}$ & 3 & $\begin{array}{l}\text { Similar cover of Arctostaphylos uva-ursi otherwise the } \\
\text { species composition was quite different from the present } \\
\text { classification. }\end{array}$ \\
\hline $\begin{array}{l}\text { Arctostaphylos uva-ursi / Solidago } \\
\text { multiradiata Dwarf-shrubland type } \\
\text { (CEGL005832) (NatureServe 2004) }\end{array}$ & 3 & $\begin{array}{l}\text { Although Arctostaphylos } u v a-u r s i \text { was dominant in this } \\
\text { type there were few other similarities because it was a } \\
\text { subalpine and lower alpine community with quite } \\
\text { different species composition. }\end{array}$ \\
\hline
\end{tabular}




\subsubsection{Arctostaphylos uva-ursi / Calamovilfa longifolia Dwarf-shrubland}

Common Bearberry / Sand Grass Dwarf-shrubland

This type does not appear to be common in the two study areas and only one plot was completed in the Holmes Crossing Sandhills Ecological Reserve (Table 46). This site was located on a mid-slope position that was south-facing and affected by insolation. The slope gradient at this plot was $25 \%$. Soils were rapidly to well drained with subxeric moisture levels and a mesotrophic nutrient regime. Surface substrates were organic (89\%) mineral soil $10 \%$, and minor amounts of decaying wood (1\%). Both Arctostaphylos uva-ursi and Calamovilfa longifolia occured at $50 \%$ cover for each species. The relatively dense cover of Calamovilfa longifolia makes this community quite recognisable while the high cover of Arctostaphylos uva-ursi was characteristic but less obvious. Stands occur in openings that may have scattered Pinus banksiana and Populus tremuloides tree cover. Other shrub cover was less than 10\% and included Amelanchier alnifolia, Rosa acicularis, and Prunus spp. Calamovilfa longifolia was dominant in the herb/graminoid layer although common species may include Oryzopsis pungens, Lathyrus ochroleucus, Astragalus striatus, Galium boreale, Fragaria virginiana, and Astragalus robbinsii.

Class: Dwarf-shrubland

Subclass: Evergreen dwarf-shrubland

Group: Needle-leaved or microphyllous evergreen dwarf-shrubland

Subgroup: Natural/Semi-natural needle-leaved or microphyllous evergreen dwarf-shrubland

Formation: Xeric Temperate or Subpolar Creeping or matted needle-leaved or microphyllous evergreen dwarf-shrubland

Alliance: Arctostaphylos uva-ursi Dwarf-shrubland Alliance

Association: Arctostaphylos uva-ursi / Calamovilfa longifolia Dwarf-shrubland

Unique Identifier: $\mathrm{n} / \mathrm{a}$

Classification Confidence Level: 1 (Weak) Only one stand was encountered during sampling and it was not well documented in the literature. Geographical range of this community type was unknown.

Dominant Species: Arctostaphylos uva-ursi, Calamovilfa longifolia

Co-Dominant Species: Pinus banksiana, Populus tremuloides, Amelanchier alnifolia, Rosa acicularis, Oryzopsis pungens

Diagnostic Species: Arctostaphylos uva-ursi, Calamovilfa longifolia

\section{Literature Review:}

The Amelanchier alnifolia / Arctostaphylos uva-ursi / Oryzopsis pungens community type (CEAB000029) was currently tracked in Alberta (Allen 2004). This type was similar but lacks the high cover of Calamovilfa longifolia. The current classification was, however, expected to fall within the Arctostaphylos uva-ursi Dwarf-Shrubland Alliance described by Wheatley and Bentz (2002). This latter type occurred in the Central Parkland Natural Subregion on sandy upland plains and included Arctostaphylos uva-ursi, Juniperus horizontalis, Heterotheca villosa, Solidago missouriensis, Artemisia frigida, Artemisia campestris, Calamovilfa longifolia and Agropyron dasystachyum. Timoney and Robinson (1998) noted that the Calamovilfa longifolia subxeric grassland was uncommon in the Ft. Assiniboine Sandhills Wildland Park. It occurrence here was considered to be a small range extension for this grass species.

The Arctostaphylos uva-ursi / Calamovilfa longifolia Dwarf-shrubland type described here was similar to a Juniperus horizontalis / Calamovilfa longifolia - Carex pensylvanica spp. heliophila type reported by Coenen (2003). This community occurred on partially stabilised dunes in the Wainwright area and shares some similarity in floristics to the current community type. The main differences with the Wainwright community were the lower cover of Arctostaphylos uva-ursi (3\%) and presence of Juniperus horizontalis, Sporobolus cryptandrus, Carex pensylvanica and absence of species present in the Boreal Sand Dune type. 
Table 46. Summary of plot data and descriptive statistics for the Arctostaphylos uva-ursi / Calamovilfa longifolia Dwarf-shrubland $(\mathrm{n}=1)$.

\begin{tabular}{|c|c|c|c|c|c|c|c|}
\hline Strata & Code & Species & $\begin{array}{l}\text { Plot } \\
\text { P27 } \\
\end{array}$ & Strata & Code & Species & $\begin{array}{l}\text { Plot } \\
\text { P27 }\end{array}$ \\
\hline S3 & ARCTUVA & $\begin{array}{l}\text { Arctostaphylos uva- } \\
\text { ursi }\end{array}$ & 50.0 & S3 & PRUNPEN & Prunus pensylvanica & 0.1 \\
\hline G & CALALON & Calamovilfa longifolia & 50.0 & $\mathrm{H}$ & ERIGGLA & Erigeron glabellus & 0.1 \\
\hline $\mathrm{T} 1$ & PINUBAN & Pinus banksiana & 10.0 & $\mathrm{H}$ & CAMPROT & $\begin{array}{l}\text { Campanula } \\
\text { rotundifolia }\end{array}$ & 0.1 \\
\hline S3 & AMELALN & Amelanchier alnifolia & 4.0 & G & CAREUMB & Carex umbellata & 0.1 \\
\hline G & ORYZPUN & Oryzopsis pungens & 2.0 & L & CLADMIT & Cladina mitis & 0.1 \\
\hline S2 & POPUTRE & Populus tremuloides & 2.0 & $\mathrm{H}$ & SOLISPA & Solidago spathulata & 0.1 \\
\hline S3 & ROSAACI & Rosa acicularis & 2.0 & $\mathrm{H}$ & SMILSTE & Smilacina stellata & 0.1 \\
\hline $\mathrm{H}$ & LATHOCH & Lathyrus ochroleucus & 1.0 & S3 & PRUNVIR & Prunus virginiana & 0.1 \\
\hline S1 & PINUBAN & Pinus banksiana & 1.0 & G & ELYMTRA & Elymus trachycaulus & 0.1 \\
\hline $\mathrm{H}$ & ASTRSTR & Astragalus striatus & 1.0 & $\mathrm{H}$ & EQUILAE & Equisetum laevigatum & 0.1 \\
\hline $\mathrm{H}$ & GALIBOR & Galium boreale & 0.1 & $\mathrm{H}$ & ASTELAE & Aster laevis & 0.1 \\
\hline $\mathrm{H}$ & FRAGVIR & Fragaria virginiana & 0.1 & $\mathrm{H}$ & ANEMMUL & Anemone multifida & 0.1 \\
\hline $\mathrm{H}$ & ASTRROB & Astragalus robbinsii & 0.1 & $\mathrm{~L}$ & CLADONI & Cladonia spp. & 0.1 \\
\hline S3 & SYMPOCC & $\begin{array}{l}\text { Symphoricarpos } \\
\text { occidentalis }\end{array}$ & 0.1 & G & FESTSAX & Festuca saximontana & 0.1 \\
\hline $\mathrm{H}$ & APOCAND & $\begin{array}{l}\text { Apocynum } \\
\text { androsaemifolium }\end{array}$ & 0.1 & & & & \\
\hline
\end{tabular}

Coenen (2003) also reported a Calamovilfa longifolia - Sporobolus cryptandrus - Carex Siccata type for the Wainwright sand dunes. It occurred on sand dunes with some active sand movement, however shared few similarities in floristics in comparison to the current classification.

Wildlands Ecological Consulting Ltd. (2004) described an Arctostaphylos uva-ursi Dwarf-shrubland community present in the Dry Mixedgrass and Mixedgrass Natural Subregions. The high percent cover of Arctostaphylos uva-ursi was common to both types yet the species compositions were quite different. Common species in this type include Juniperus communis, Hedysarum boreale, Hymenoxys acaulis, Juniperus horizontalis, Pascopyrum smithii, Koeleria macrantha, Eriogonum flavum, Achillea millefolium, and Comandra umbellatum. A second type reported on that study was Calamovilfa longifolia - Hesperostipa comata Herbaceous Vegetation. Calamovilfa longifolia was dominant but Arctostaphylos uva-ursi was not recorded for this type. Adams et al. (1997) described a similar Calamovilfa longifolia Hesperostipa comata type that occurred near Suffield, Alberta.

No similar community types were listed by NatureServe (2004) or by Allen (2004). Similarity ratings for related plant community types are provided in Table 47. 
Table 47. Correlation table of plant community types with similarity ratings for the Arctostaphylos uvaursi / Calamovilfa longifolia type.

\begin{tabular}{|c|c|c|}
\hline $\begin{array}{c}\text { Similar Types } \\
\end{array}$ & $\begin{array}{c}\text { Similarity } \\
\text { Rating } \\
\end{array}$ & Comments \\
\hline $\begin{array}{l}\text { Amelanchier alnifolia / } \\
\text { Arctostaphylos uva-ursi / Oryzopsis } \\
\text { pungens CT (CEAB000029) (Allen } \\
\text { 2004) }\end{array}$ & 3 & $\begin{array}{l}\text { Calamovilfa longifolia was not a dominant species but } \\
\text { this was a related type of community in the Dry } \\
\text { Mixedwood Natural Subregion. }\end{array}$ \\
\hline $\begin{array}{l}\text { Arctostaphylos uva-ursi Dwarf- } \\
\text { Shrubland Alliance (Wheatley and } \\
\text { Bentz 2002) }\end{array}$ & 2 & $\begin{array}{l}\text { Occurred in the parkland on sandy sites and has very } \\
\text { similar species composition. }\end{array}$ \\
\hline $\begin{array}{l}\text { Calamovilfa longifolia CT (Timoney } \\
\text { and Robinson 1998) }\end{array}$ & $1(2)$ & $\begin{array}{l}\text { Based on the proximity of the study areas and dominant } \\
\text { species present in this type of grassland they were } \\
\text { expected to be the same or closely related types. }\end{array}$ \\
\hline $\begin{array}{l}\text { Juniperus horizontalis / Calamovilfa } \\
\text { longifolia - Carex pensylvanica spp. } \\
\text { heliophila CT (Coenen 2003) }\end{array}$ & 2 & $\begin{array}{l}\text { Similar floristics but Arctostaphylos uva-ursi cover was } \\
\text { much lower in this type and the other two indicator } \\
\text { species were not recorded on the current study. }\end{array}$ \\
\hline $\begin{array}{l}\text { Calamovilfa longifolia - } \\
\text { Sporobolus cryptandrus - Carex } \\
\text { Siccata CT (Coenen 2003) }\end{array}$ & 3 & $\begin{array}{l}\text { Calamovilfa longifolia was a dominant species as well } \\
\text { but Arctostaphylos } u v a \text {-ursi was not and there were other } \\
\text { significant differences in species composition. }\end{array}$ \\
\hline $\begin{array}{l}\text { Arctostaphylos uva-ursi Dwarf- } \\
\text { shrubland (Wildlands Ecological } \\
\text { Consulting Ltd. 2004) }\end{array}$ & 3 & $\begin{array}{l}\text { Arctostaphylos uva-ursi cover was dense in both types } \\
\text { but otherwise the species composition was quite different } \\
\text { from the present classification. }\end{array}$ \\
\hline $\begin{array}{l}\text { Calamovilfa longifolia - } \\
\text { Hesperostipa comata Herbaceous } \\
\text { Vegetation (Adams et al. } 1997 \text {, } \\
\text { Wildlands Ecological Consulting Ltd. } \\
\text { 2004) }\end{array}$ & 3 & $\begin{array}{l}\text { Calamovilfa longifolia was a dominant species but no } \\
\text { Arctostaphylos uva-ursi was present in this type. }\end{array}$ \\
\hline $\begin{array}{l}\text { Arctostaphylos uva-ursi / Solidago } \\
\text { multiradiata Dwarf-shrubland } \\
\text { (CEGL005832) (NatureServe 2004) }\end{array}$ & 3 & $\begin{array}{l}\text { Although Arctostaphylos uva-ursi was dominant in this } \\
\text { type there were few other similarities because it was a } \\
\text { subalpine and lower alpine community with quite } \\
\text { different species composition. }\end{array}$ \\
\hline
\end{tabular}




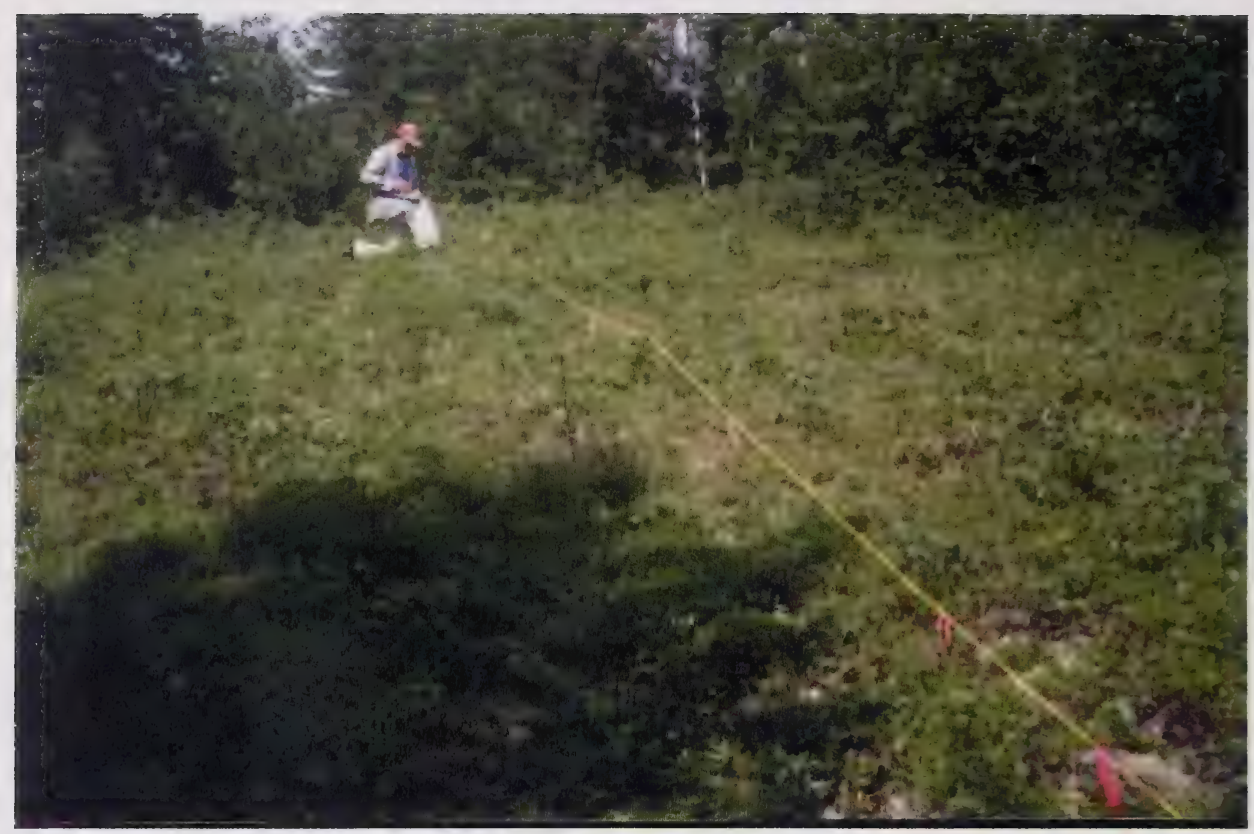

Plate 22. Arctostaphylos uva-ursi / Oryzopsis pungens Dwarf Shrubland (P2).

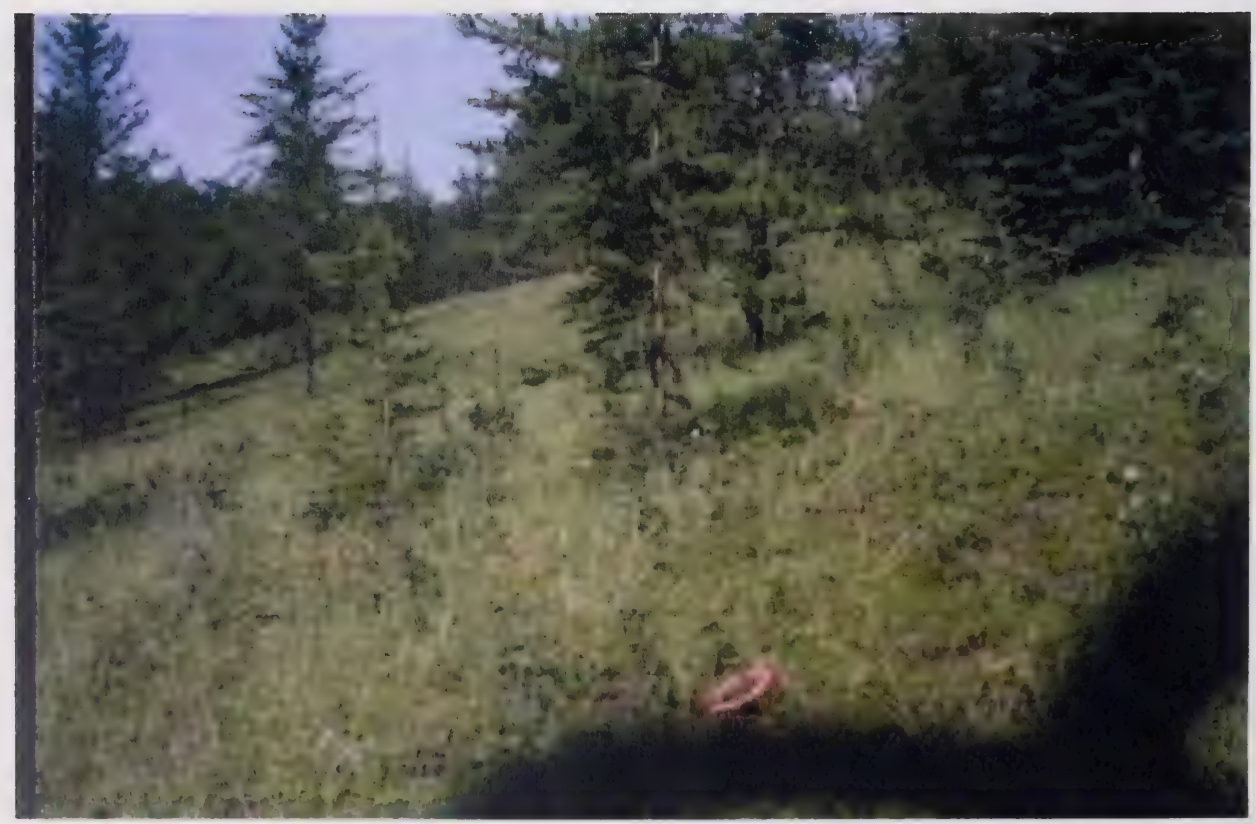

Plate 23. Arctostaphylos uva-ursi / Calamovilfa longifolia Dwarf Shrubland (P27). 


\subsubsection{Picea mariana /Ledum groenlandicum / Sphagnum fuscum Dwarf-shrubland}

Black Spruce / Labrador-tea / Sphagnum Dwarf-shrubland

This was likely a relatively common type and one plot was completed for this community type in the North Buck Lake study area (Table 48). It occurred in an interdune depression where the water table remains close to the surface over the entire year. Soils were Organic with hygric moisture levels and a submesotrophic nutrient regime. There was no tree layer in this community although stunted Picea mariana trees, less than $5 \mathrm{~m}$ tall, were present in the shrub layers. Picea mariana was present in the tall, mid and low shrub layers at $1 \%, 20 \%$, and $4 \%$ cover values, respectively. Ledum groenlandicum $(80 \%)$ and Vaccinium vitis-idaea (20\%) dominated the low shrub cover. The moss layer was dense, dominated by Sphagnum fuscum (80\%) and other sphagnum mosses (5\%). Other common species included Oxycoccus microcarpus, Rubus arcticus, and Cladina mitis.

Class: Dwarf-shrubland

Subclass: Evergreen dwarf-shrubland

Group: Needle-leaved or microphyllous evergreen dwarf-shrubland

Subgroup: Natural/Semi-natural needle-leaved or microphyllous evergreen dwarf-shrubland

Formation: Saturated needle-leaved or microphyllous evergreen dwarf-shrubland with a sparse needleleaved evergreen tree layer

Alliance: Picea mariana Saturated Dwarf-shrubland Alliance

Association: Picea mariana / Ledum groenlandicum / Sphagnum fuscum Dwarf-shrubland

Unique Identifier:

Classification Confidence Level: 1 (Strong) Common type that was easily identifiable, was well documented, and has a wide geographic distribution throughout the boreal region.

Dominant Species: Picea mariana, Ledum groenlandicum, Vaccinium vitis-idaea, Sphagnum fuscum Co-Dominant Species: Oxycoccus microcarpus, Rubus arcticus, Cladina mitis

Diagnostic Species: Ledum groenlandicum, Oxycoccus microcarpus, Vaccinium vitis-idaea, Rubus arcticus, Sphagnum spp.

Table 48. Summary of plot data and descriptive statistics for the Picea mariana / Ledum groenlandicum / Sphagnum fuscum Dwarf-shrubland community type $(\mathrm{n}=1)$.

\begin{tabular}{|c|c|c|c|c|c|c|c|}
\hline \multirow[b]{2}{*}{ Strata } & \multirow[b]{2}{*}{ Code } & \multirow[b]{2}{*}{ Species } & Plot & \multirow[b]{2}{*}{ Strata } & \multirow[b]{2}{*}{ Code } & \multirow[b]{2}{*}{ Species } & \multirow{2}{*}{$\frac{\text { Plot }}{58}$} \\
\hline & & & 58 & & & & \\
\hline S3 & LEDUGRO & Ledum groenlandicum & 80.0 & G & ERIOVAG & Eriophorum vaginatum & 1.0 \\
\hline M & SPHAFUS & Sphagnum fuscum & 80.0 & M & POHLNUT & Pohlia nutans & 1.0 \\
\hline S3 & VACCVIT & Vaccinium vitis-idaea & 20.0 & S1 & PICEMAR & Picea mariana & 1.0 \\
\hline S2 & PICEMAR & Picea mariana & 20.0 & M & MOSSES\$\$ & Moss spp. & 1.0 \\
\hline M & SPHAGNU & Sphagnum spp. & 5.0 & $\mathrm{~L}$ & CLADDEF & Cladonia deformis & 0.1 \\
\hline $\mathrm{L}$ & CLADMIT & Cladina mitis & 4.0 & M & AULAPAL & Aulacomnium palustre & 0.1 \\
\hline S3 & PICEMAR & Picea mariana & 4.0 & $\mathrm{~L}$ & CLADBEL & Cladonia bellidiflora & 0.1 \\
\hline S3 & OXYCMIC & Oxycoccus microcarpus & 3.0 & $\mathrm{H}$ & SMILTRI & Smilacina trifolia & 0.1 \\
\hline $\mathrm{H}$ & RUBUACA & Rubus arcticus & 2.0 & & & & \\
\hline
\end{tabular}




\section{Literature Review:}

Hermesh (1972) described an interdune wetland type in the Athabasca Lake area that was dominated by Picea mariana, Larix laricina, Ledum groenlandicum, and Sphagnum spp. These "slacks" may have standing water through the summer but no further details were provided for this community. Allen et al. (2003) reported a Picea mariana / Ledum groenlandicum / Sphagnum fuscum community type that occurred in the Fidler-Greywillow Provincial Park at Lake Athabasca. This type was considered to be widespread in the region. It was found to occur in small basin bogs, adjacent poor fen complex, and on permafrost islands in a large fen. Allen and Johnson (no date.) described a Picea mariana / Chamaedaphne calyculata - Kalmia polifolia / Sphagnum spp. community type from Marguerite Crag and Tail Wildland Park. No details were provided regarding this type other than it occurred in a bog between sand deposits and crag areas. Mackenzie River Basin Committee (1981) identified a Ledum groenlandicum / Sphagnum spp. community at Lake Athabasca. It was found on moist to wet organic soils in depressional areas and along lakeshores. Tree cover was generally less than $5 \%$ cover consisting of stunted Picea mariana ( $\leq 2 \mathrm{~m}$ tall) with occasional Larix laricina trees. Ledum groenlandicum dominated the shrub layer and was co-dominant with Chamaedaphne calyculata. Important species in the herb layer included Rubus chamaemorus, sedges. Moss cover was high and consisted mainly of Sphagnum fuscum and $S$. magellanicum.

Alberta Energy and Natural Resources (1978a, 1978b) identified a treed bog type for the Wapiti - Grande Prairie sand dunes as Picea mariana - Larix laricina / Ledum groenlandicum-Salix spp. / Sphagnum sp. This interdune community occurred on depressional to level sites with generally poorly drained organic soils.

Beckingham and Archibald (1996) identify a Picea mariana - Larix laricina / Betula pumila / Carex spp. / Sphagnum spp. shrub type (j2.1) in the boreal mixedwood. Site conditions appeared similar to the site completed at North Buck Lake. The j2.1 type had very similar plant species composition with the exception that the current plot did not support Larix laricina, Betula pumila, Salix spp., Rubus chamaemorus, Carex spp. or Tomentypnum nitens. Beckingham and Archibald (1996) identify a second shrubby bog type as Picea mariana - Larix laricina / Betula pumila / Carex spp. / Sphagnum spp. (i2.1). This was a boreal mixedwood community that occurred on similar sites. Species composition was very similar, however, Chamaedaphne calyculata, Rubus chamaemorus, Pleurozium schreberi, and Polytrichum strictum did not occur in the North Buck Lake plot.

NatureServe (2004) identified a Picea mariana - (Larix laricina) / Ledum groenlandicum / Sphagnum spp. Forest (CEGL005271) found in boreal regions of central and eastern Canada and adjacent areas in the United States. Sites were poorly drained with thick peat layers and low nutrient levels. The canopy was generally closed Picea mariana with some cover of Abies balsamea, Larix laricina, and Pinus banksiana (Sims et al. 1989). Shrub layer cover was moderately high consisting of Chamaedaphne calyculata, Gaultheria hispidula, Kalmia polifolia, Ledum groenlandicum, and Vaccinium myrtilloides, and Cornus canadensis. The herbaceous layer was thin consisting of Carex trisperma, Eriophorum vaginatum var. spissum, Clintonia borealis, and Maianthemum trifolium (= Smilacina trifolia). The moss layer was dense and consisted of Sphagnum spp., Dicranum polysetum, and Pleurozium schreberi.

NatureServe (2004) lists a Picea mariana / Ledum groenlandicum / Carex trisperma / Sphagnum spp. Forest (CEGL002485) ranked G5. It was a raised bog community found in the sub-boreal to boreal regions of Quebec to Manitoba (Sims et al. 1989) in Canada and adjacent areas of the United States. Stands were typically in large peatland complexes on sites that were poorly drained Organic soils. Picea mariana cover was commonly at least $25 \%$ canopy and scattered Larix laricina may be present. Ledum groenlandicum cover was high and other common shrubs include Chamaedaphne calyculata, Vaccinium myrtilloides, Vaccinium oxycoccos, Kalmia polifolia, Kalmia angustifolia, Gaultheria hispidula, and Andromeda polifolia. The herb/graminoid was may contain Carex trisperma, Eriophorum vaginatum, and 
Maianthemum trifolium. Moss cover was high and consisted of Sphagnum magellanicum, Sphagnum fuscum, Sphagnum recurvum, and Sphagnum angustifolium, and some Sphagnum capillifolium (= Sphagnum nemoreum) and Sphagnum girgensohnii. Patches of Pleurozium schreberi or other feather moss may be present.

NatureServe (2004) lists a Picea mariana / Ledum groenlandicum / Sphagnum spp. Dwarf-shrubland (CEGL002525) that was ranked GNR. This type was based on a concept developed by the Manitoba CDC classification (Greenall 1996). It occurred in Manitoba and Ontario.

A muskeg type that was widespread through the sub-boreal regions of Canada was the Picea mariana / Chamaedaphne calyculata / Sphagnum spp. Dwarf-shrubland (CEGL005218) (NatureServe 2004). This peatland type was found mainly on the crests of raised bogs and in basin bogs. Stands consist of stunted Picea mariana and Larix laricina. Dominant low shrub species include Andromeda polifolia var. glaucophylla, Chamaedaphne calyculata, Kalmia polifolia, Ledum groenlandicum, Gaultheria hispidula and Vaccinium oxycoccos. The herbaceous layer included Carex oligosperma, Carex pauciflora, Eriophorum vaginatum, Maianthemum stellatum and Sarracenia purpurea. Sphagnum spp. including Sphagnum fuscum and Sphagnum magellanicum formed continuous mats often with patches of Pleurozium schreberi. Similarity ratings for related plant community types are provided in Table 49.

Table 49. Correlation table of plant community types with similarity ratings for the Picea mariana / Ledum groenlandicum / Sphagnum fuscum type.

\begin{tabular}{||l|c|l||}
\hline \multicolumn{1}{|c|}{ Similar Types } & $\begin{array}{c}\text { Similarity } \\
\text { Rating }\end{array}$ & \multicolumn{1}{|c||}{ Comments } \\
\hline \hline $\begin{array}{l}\text { Picea mariana } \text { - Larix laricina / } \\
\text { Ledum groenlandicum /Sphagnum sp. } \\
\text { CT (Hermesh 1972) }\end{array}$ & 2 & $\begin{array}{l}\text { Appears to be the same type but no details available } \\
\text { regarding percent cover or associated species. }\end{array}$ \\
\hline $\begin{array}{l}\text { Picea mariana / Ledum } \\
\text { groenlandicum / Sphagnum fuscum } \\
\text { Woodland/Forest (Allen } \text { et al. 2003) }\end{array}$ & $1(2)$ & $\begin{array}{l}\text { No details were available for this review but this CT was } \\
\text { considered to be widespread in the region. }\end{array}$ \\
\hline $\begin{array}{l}\text { Picea mariana / Chamaedaphne } \\
\text { calyculata - Kalmia polifolia / } \\
\text { Sphagnum spp. CT (Allen and } \\
\text { Johnson no date.) }\end{array}$ & 3 & $\begin{array}{l}\text { Possibly a similar community type but no details were } \\
\text { available regarding the height of the Picea mariana, } \\
\text { species composition, or percent ground cover of } \\
\text { dominants. }\end{array}$ \\
\hline $\begin{array}{l}\text { Picea mariana - Larix laricina / } \\
\text { Ledum groenlandicum- Salix spp. / } \\
\text { Sphagnum sp. CT (Alberta Energy } \\
\text { and Natural Resources 1978a, 1978b) }\end{array}$ & $2(1)$ & $\begin{array}{l}\text { Limited details were provided on this community but it } \\
\text { appears to be the same type as the current classification. }\end{array}$ \\
\hline $\begin{array}{l}\text { Picea mariana - Larix laricina / } \\
\text { Betula pumila / Carex spp. / } \\
\text { Sphagnum spp. CT (j2.1) } \\
\text { (Beckingham and Archibald 1996) }\end{array}$ & $2(3)$ & $\begin{array}{l}\text { Very similar type although there were several important } \\
\text { differences in dominant or diagnostic species. }\end{array}$ \\
\hline $\begin{array}{l}\text { Picea mariana - Larix laricina / } \\
\text { Betula pumila / Carex spp. / } \\
\text { Sphagnum spp. CT (i2.1) } \\
\text { (Beckingham and Archibald 1996) }\end{array}$ & $2(1)$ & $\begin{array}{l}\text { Minor differences in plant composition attributed to } \\
\text { small sample site on current study and slight differences } \\
\text { in site moisture regime. }\end{array}$ \\
\hline $\begin{array}{l}\text { Picea mariana / Ledum } \\
\text { groenlandicum / Sphagnum spp. } \\
\text { Dwarf-shrubland (CEGL002525) } \\
\text { (NatureServe 2004) }\end{array}$ & $1(2)$ & $\begin{array}{l}\text { Limited data available for review but this appears to be } \\
\text { the same type. }\end{array}$ \\
\hline
\end{tabular}




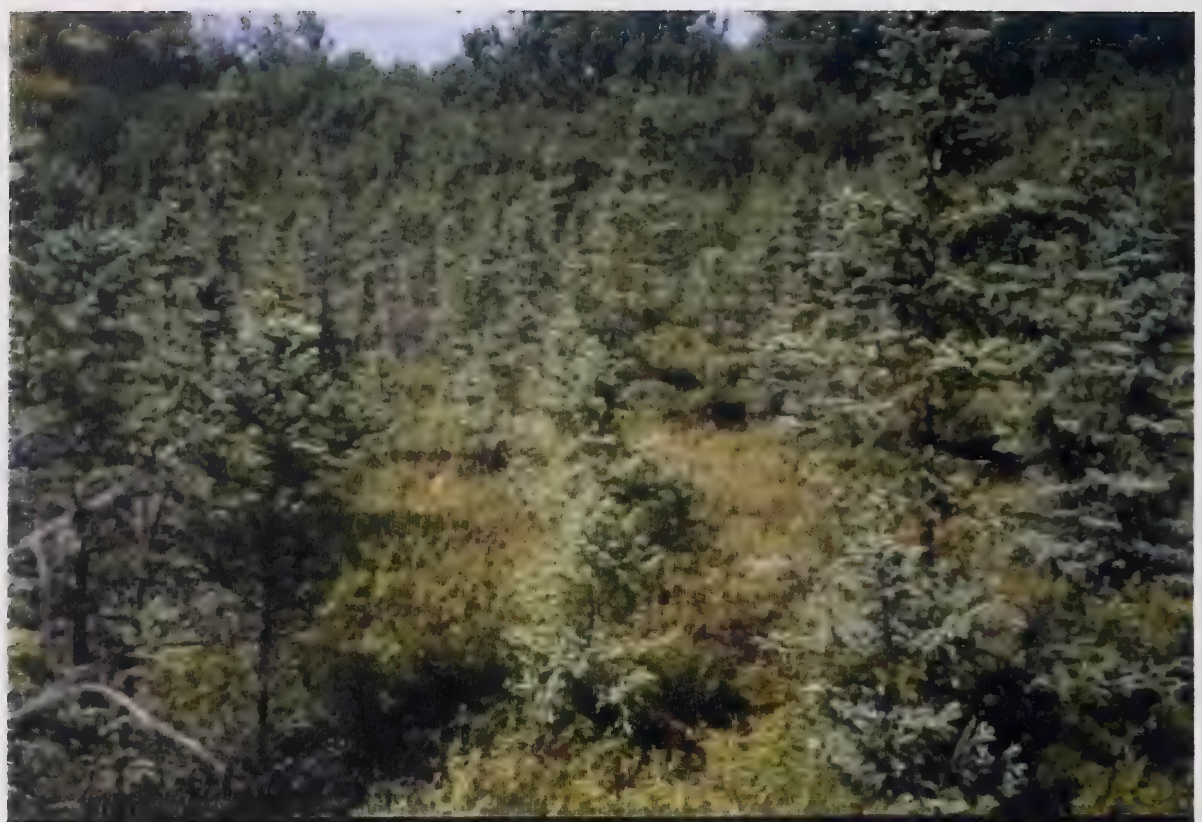

Plate 24. Picea mariana / Ledum groenlandicum / Sphagnum fuscum Dwarf-shrubland (P58). 


\subsubsection{Herbaceous Vegetation}

\subsubsection{Carex diandra Wet Meadow Herbaceous Vegetation \\ Two-stamen Sedge Wet Meadow Herbaceous Vegetation}

This sedge fen community was found in wet depressions between transverse dunes. One sample was completed in the Holmes Crossing Sandhills Ecological Reserve (Table 50). It was not observed in North Buck Lake although it was expected to occur there also. Sites were very poorly drained with subhydric moisture levels and the thick Organic soils had a permesotrophic nutrient regime. Surface substrates were organic matter $(80 \%)$ with standing water $(20 \%)$ and a trace of decaying wood. Species diversity was low and Carex diandra was the dominant species. Associated species included Polygonum amphibium,

Potentilla norvegica, and Carex chordorrhiza. Plot 24 also supported Carex diandra yet was a wetter site that was dominated by Carex utriculata.

Class: Herbaceous Vegetation

Subclass: Perennial graminoid vegetation

Group: Temperate or subpolar grassland

Subgroup: Natural/Semi-natural temperate or subpolar grassland

Formation: Seasonally flooded temperate or subpolar grassland

Alliance: Carex spp. Seasonally Flooded Herbaceous Alliance

Association: Carex diandra Wet Meadow Herbaceous Vegetation

Unique Identifier: NatureServe CEGL002549

Classification Confidence Level: 3 (Weak) Only one plot completed in this type and it was not well defined in the literature. A similar type was known to occur in Manitoba.

Dominant Species: Carex diandra

Co-Dominant Species: Polygonum amphibium, Potentilla norvegica, Carex chordorrhiza

Diagnostic Species: Carex diandra

Table 50. Summary of plot data and descriptive statistics for the Carex diandra community type $(\mathrm{n}=1)$.

\begin{tabular}{|c|c|c|c|}
\hline Strata & Code & Species & $\begin{array}{l}\text { Plots } \\
\text { P12 } \\
\end{array}$ \\
\hline $\mathrm{G}$ & CAREDIA & Carex diandra & 11.0 \\
\hline $\mathrm{H}$ & POLYAMP & Polygonum amphibium & 4.0 \\
\hline G & CARECHO & Carex chordorrhiza & 4.0 \\
\hline $\mathrm{H}$ & POTENOR & Potentilla norvegica & 2.0 \\
\hline M & MOSSES\$\$ & Unidentified Moss spp. & 2.0 \\
\hline G & AGROSCA & Agrostis scabra & 0.1 \\
\hline
\end{tabular}

\section{Literature Review:}

Beckingham and Archibald (1996) identified a Carex spp. fen community (k3.1) in the boreal mixedwood. The species of Carex were not provided for this type but this would appear to be a related community. Other diagnostic species for this type included Potentilla palustris, Menyanthes trifoliata, Brachythecium spp. and Drepanocladus spp. 
NatureServe (2004) lists a Carex diandra Wet Meadow Herbaceous Vegetation (CEGL002549) that occurred in Manitoba (Greenall 1996). Carex diandra was the dominant species but no further details regarding this type were provided. No other similar types were located for this review. Similarity ratings for related plant community types are provided in Table 51.

Table 51. Correlation table of plant community types with similarity ratings for Carex diandra type.

\begin{tabular}{||l|c|l||}
\hline \multicolumn{1}{|c|}{ Similar Types } & $\begin{array}{c}\text { Similarity } \\
\text { Rating }\end{array}$ & \multicolumn{1}{c||}{ Comments } \\
\hline \hline $\begin{array}{l}\text { Carex diandra Wet Meadow } \\
\text { Herbaceous Vegetation CEGL002549 } \\
\text { (NatureServe 2004) }\end{array}$ & 2 & $\begin{array}{l}\text { Carex diandra was the dominant species and this type } \\
\text { was reported to occur in Manitoba. No other data } \\
\text { provided to further confirm similarity of type. }\end{array}$ \\
\hline $\begin{array}{l}\text { Carex spp. fen CT (k3.1) } \\
\text { (Beckingham and Archibald 1996) }\end{array}$ & $3(2)$ & $\begin{array}{l}\text { Species of Carex was not provided but was a similar } \\
\text { community. }\end{array}$ \\
\hline
\end{tabular}

\subsubsection{Carex utriculata Herbaceous Vegetation Small Bottle Sedge Herbaceous Vegetation}

This wetland community occurred in interdune depression sites where the water table remains at or near ground level throughout the year. It was not encountered in the North Buck Lake study area and only one site was sampled in the Holmes Crossing Sandhills Ecological Reserve (Table 52). At this site there was approximately $15 \mathrm{~cm}$ of standing water present at the date of sampling. Soils consisted of a thick layer of Organic materials that were very poorly drained resulting in hydric moisture levels and a mesotrophic nutrient regime. Surface substrates were mainly water $(70 \%)$, organic materials $(30 \%)$, and a trace of decaying wood. Species diversity was low and the dominant species was Carex utriculata, which was the diagnostic species that defines the community. Other typical species included Carex diandra and Equisetum fluviatile.

Class: Herbaceous Vegetation

Subclass: Perennial graminoid vegetation

Group: Temperate or subpolar grassland

Subgroup: Natural/Semi-natural temperate or subpolar grassland

Formation: Seasonally flooded temperate or subpolar grassland

Alliance: Carex (rostrata, utriculata) Seasonally Flooded Herbaceous Alliance

Association: Carex utriculata Herbaceous Vegetation

Unique Identifier: $\mathrm{n} / \mathrm{a}$

Classification Confidence Level: 3 (Weak) Only one plot was completed in this type and there was considerable variation in community types reviewed in the literature. Geographical distribution was uncertain.

Dominant Species: Carex utriculata

Co-Dominant Species: Carex diandra, Equisetum fluviatile

Diagnostic Species: Carex utriculata 
Table 52. Summary of plot data and descriptive statistics for the Carex utriculata community type $(\mathrm{n}=1)$.

\begin{tabular}{|c|c|c|c|}
\hline \multirow[b]{2}{*}{ Strata } & \multirow[b]{2}{*}{ Code } & \multirow[b]{2}{*}{ Species } & \multirow{2}{*}{$\begin{array}{l}\text { Plot } \\
\text { P24 }\end{array}$} \\
\hline & & & \\
\hline $\bar{G}$ & CAREUTR & Carex utriculata & 15.0 \\
\hline G & CAREDIA & Carex diandra & 7.0 \\
\hline $\mathrm{H}$ & EQUIFLU & Equisetum fluviatile & 0.5 \\
\hline
\end{tabular}

\section{Literature Review:}

Timoney and Robinson (1998) identified one related type in the Ft. Assiniboine Sandhills Wildland Park. This community was described as a Carex lasiocarpa - C. utriculata - C. chordorhiza / Drepanocladus revolvens type.

Allen et al. (2002) observed a Carex utriculata - C. atherodes community that occurred in the La Butte Creek Wildland Provincial Park located north of Lake Athabasca. This was a narrow wet meadow that included patches of Equisetum fluviatile, and some C. aquatilis and Potentilla palustris. Allen et al. (2003) noted that the Carex utriculata type was present but not common in the Fidler-Greywillow Wildland Provincial Park at Lake Athabasca. Here it was found at the edge of a wetland behind shoreline dunes. Allen and Johnson (no date.) described a Carex utriculata community type from the Richardson River Dunes Wildland Park. Here it was found in a small bowl wetland located in the centre of parabolic dune. Meijer (2002b) also identified a Salix pedicellaris - Carex utriculata community for the Richardson River Dunes Wildland Park. Salix pedicellaris and Carex utriculata cover was $4 \%$ and $25 \%$, respectively. Other wetland species included Equisetum fluviatile, Potentilla palustris, and Petasites sagittatus.

Beckingham and Archibald (1996) identified a Carex spp. fen community (k3.1) in the boreal mixedwood. The species of Carex were not provided for this type but this would appear to be a related community. Other diagnostic species for this type include Potentilla palustris, Menyanthes trifoliata, Brachythecium spp. and Drepanocladus spp.

This community type shares similarities with several other wetland types and may intergrade into Carex aquatilis communities or the Carex diandra Community Type. Thompson and Hansen (2002) indicated that it was a widespread type and analysed 50 stands from southern Alberta and the United States. In the United States it occurred in Sierra Nevada meadows in California, riparian areas in Montana, Idaho and Utah, and wetlands in Yellowstone National Park, Wyoming. This was a very wet community type that occurred adjacent to low gradient streams in wide valley bottoms, beaver ponds, or near perennial seeps. Standing water was common but sites may become relatively dry later in the season (Thompson and Hansen 2002). Soils were typically Organic and water tables remain at or above the ground surface throughout the growing season. In comparison to Carex aquatilis stands soils in the Carex utriculata community type were more anaerobic.

NatureServe (2004) describes a Carex utriculata community type (CEGL001562) that occurred throughout much of the western United States. Typically it occurred in montane and subalpine areas adjacent to lakes, beaver ponds, slow-moving streams, marshy areas, and overflow channels on broad floodplains. Soils were variable but the water table stays near the soil surface for the majority of the growing season. Graminoids were the dominant vegetation although there may be a few scattered willows. Carex utriculata cover dominates these stands ( $20 \%$ to $99 \%$ cover) with less cover of other graminoids such as Carex lenticularis, Carex aquatilis, and Carex microptera, Calamagrostis canadensis, Glyceria striata, and Juncus balticus. The forb layer was sparse but usually included Geum macrophyllum, Mentha arvensis, and Mimulus guttatus. A second similar type listed by NatureServe (2004) was the Carex 
aquatilis - Carex utriculata Herbaceous Vegetation (CEGL001803). In this type Carex aquatilis and Carex utriculata had approximately equal cover values.

Based on the dominance of Carex utriculata in the communities described above they were considered to be essentially the same type as the current classification. The main differences were the presence of Carex diandra in the boreal sand dunes plot and the absence of wetlands species common to southern Alberta and the United States. Similarity ratings for related plant community types are provided in Table 53.

Table 53. Correlation table of plant community types with similarity ratings for the Carex utriculata type.

\begin{tabular}{|c|c|c|}
\hline Similar Types & $\begin{array}{l}\text { Similarity } \\
\text { Rating }\end{array}$ & Comments \\
\hline $\begin{array}{l}\text { Carex utriculata / Moss spp. CT } \\
\text { (Nelson et al. 1989) }\end{array}$ & 1 & $\begin{array}{l}\text { Same community type based on very similar site } \\
\text { characteristics and floristics. }\end{array}$ \\
\hline $\begin{array}{l}\text { Carex lasiocarpa }- \text { C. utriculata }-C . \\
\text { chordorhiza / Drepanocladus } \\
\text { revolvens CT (Timoney and } \\
\text { Robinson 1998) }\end{array}$ & 3 & $\begin{array}{l}\text { This was likely a related type but there appears to be } \\
\text { significant differences based on dominant species listed } \\
\text { for the type. No details regarding floristics of the stand } \\
\text { were available for direct comparison. }\end{array}$ \\
\hline $\begin{array}{l}\text { Carex utriculata-C. atherodes CT } \\
\text { (Allen et al. 2002) }\end{array}$ & 3 & $\begin{array}{l}\text { Likely a similar type but no Carex atherodes was noted } \\
\text { in the current community type. }\end{array}$ \\
\hline $\begin{array}{l}\text { Carex utriculata CT (Allen et al. } \\
\text { 2003) }\end{array}$ & $1(2)$ & $\begin{array}{l}\text { Based on limited information available this was } \\
\text { considered to be the same type. }\end{array}$ \\
\hline $\begin{array}{l}\text { Carex utriculata CT (Allen and } \\
\text { Johnson no date) }\end{array}$ & $1(2)$ & $\begin{array}{l}\text { No details were provided but was expected to be the } \\
\text { same type }\end{array}$ \\
\hline $\begin{array}{l}\text { Salix pedicellaris - Carex utriculata } \\
\text { CT (Meijer } 2002 \mathrm{~b} \text { ) }\end{array}$ & $3(2)$ & $\begin{array}{l}\text { Species composition and percent cover was different but } \\
\text { This was considered a related Carex utriculata type. }\end{array}$ \\
\hline $\begin{array}{l}\text { Carex spp. fen CT (k3.1) } \\
\text { (Beckingham and Archibald 1996) }\end{array}$ & $3(2)$ & $\begin{array}{l}\text { Species of Carex was not provided but was a similar } \\
\text { community. }\end{array}$ \\
\hline $\begin{array}{l}\text { Carex utriculata CT (Thompson and } \\
\text { Hansen 2002) }\end{array}$ & 2 & $\begin{array}{l}\text { Shares same diagnostic species and site characteristics } \\
\text { but no Carex diandra indicated and much reduced } \\
\text { species diversity. }\end{array}$ \\
\hline $\begin{array}{l}\text { Carex utriculata CT (CEGL001562) } \\
\text { (NatureServe 2004) }\end{array}$ & 2 & $\begin{array}{l}\text { Same type but there was some variance in floristics } \\
\text { attributed to differences in species ranges for the two } \\
\text { types. }\end{array}$ \\
\hline $\begin{array}{l}\text { Carex aquatilis - Carex utriculata } \\
\text { Herbaceous Vegetation } \\
\text { (CEGL001803) (NatureServe 2004) }\end{array}$ & 3 & $\begin{array}{l}\text { This type was confined to mountain habitats and has } \\
\text { significant cover of Carex aquatilis in contrast to the } \\
\text { current classification. Also Carex diandra was not } \\
\text { included as an important species. }\end{array}$ \\
\hline
\end{tabular}




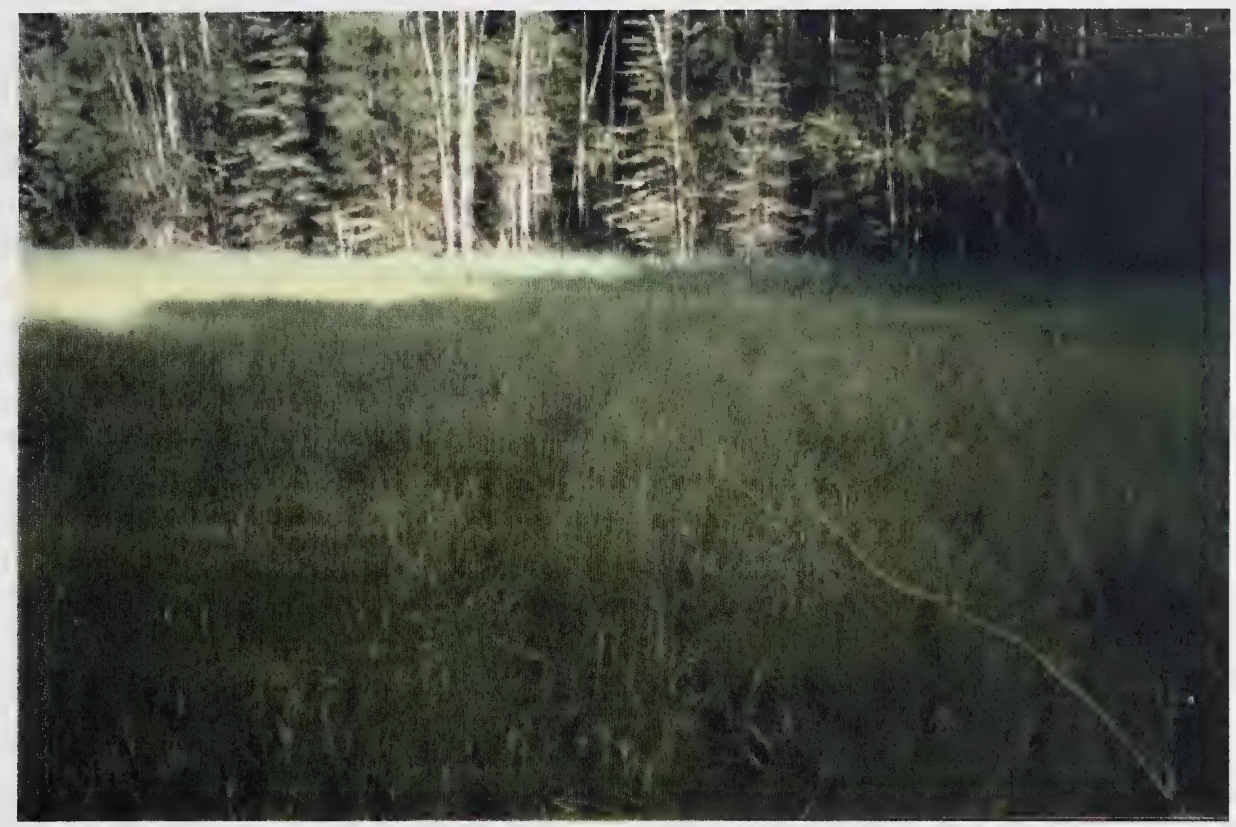

Plate 25. Carex diandra Wet Meadow Herbaceous Vegetation (P12).

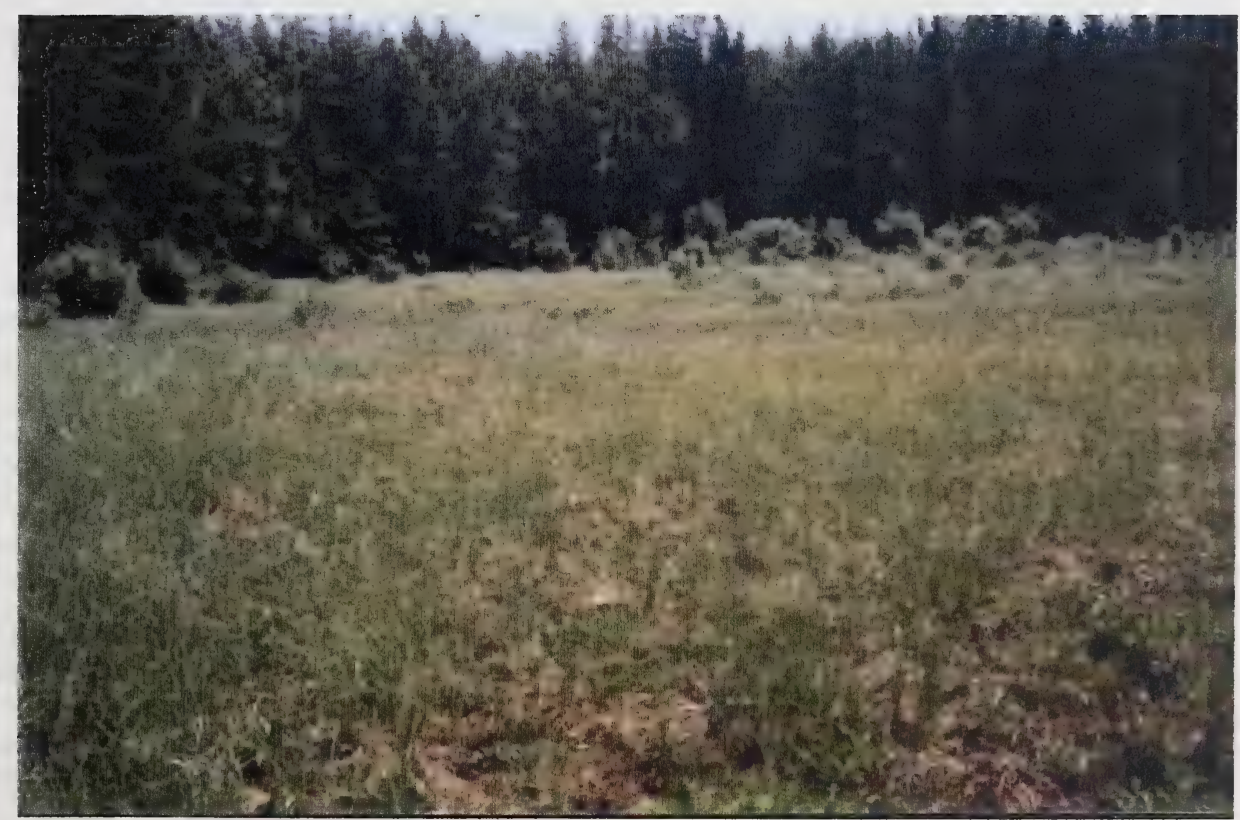

Plate 26. Carex utriculata Herbaceous Vegetation (P24). 


\subsubsection{Calamagrostis canadensis - Potentilla palustris Herbaceous Vegetation}

Bluejoint - Marsh Cinquefoil Herbaceous Vegetation

This community type appears to be common in both study areas. It occurred in interdune depressions often forming a distinctive band of vegetation around the perimeter of sedge fens and an intergrade to upland sites. Three sites were sampled including one in Holmes Crossing Sandhills Ecological Reserve and two in North Buck Lake study area (Table 54). Calamagrostis canadensis content was typically high with a mean ground cover of $60 \%$ and ranging between $50 \%$ and $70 \%$. Diagnostic species for this community type were Calamagrostis canadensis and Potentilla palustris. Other species were variable and may include Petasites spp., Sphagnum spp., Salix bebbiana, Salix pedicellaris, Salix pyrifolia, Polygonum amphibium, Carex spp., Equisetum fluviatile, Caltha palustris, Drepanocladus aduncus and other wetland species. Sites may be subjected to periodic or frequent flooding and seasonal drawdown. A thick layer of Organic soils were typical and these were imperfectly to very poorly drained. Moisture regimes were hydric to subhygric soil nutrient regimes were mesotrophic to permesotrophic. Standing water was common at sites at the plots sampled and averaged $11 \%$ of the ground surface area with organic matter accounting for the remaining $89 \%$.

Class: Herbaceous Vegetation

Subclass: Perennial graminoid vegetation

Group: Temperate or subpolar grassland

Subgroup: Natural/Semi-natural temperate or subpolar grassland

Formation: Saturated temperate or subpolar grassland

Alliance: Calamagrostis canadensis Seasonally Flooded Herbaceous Alliance

Association: Calamagrostis canadensis - Potentilla palustris Herbaceous Vegetation

Unique Identifier: $\mathrm{n} / \mathrm{a}$

Classification Confidence Level: 2 (Moderate) This community type forms a inter-grade between upland sites and permanently flooded lowland areas. It appears to be relatively common in both study areas and a similar type has been recorded in the Birch Mountains of northern Alberta.

Dominant Species: Calamagrostis canadensis

Co-Dominant Species: Potentilla palustris, Petasites frigidus var sagittatus, Sphagnum magellanicum Diagnostic Species: Calamagrostis canadensis, Potentilla palustris

\section{Literature Review:}

Allen and Johnson (no date.) described a Alnus tenuifolia / Calamagrostis canadensis from the Marguerite Crag and Tail Wildland Park. No details regarding plant species composition were provided other than it was a wetland between sand deposits and Marguerite River. Unpublished plot data (pers. comm. Keith Ainsley 2005) from the Birch Mountains of northern Alberta indicate a similar community type occurred there (see plots BM: 48, 64, 77). Calamagrostis canadensis was the dominant cover and averaged $73 \%$ at the sites sampled. Species diversity was low but there was good correlation between species recorded for this type and the current classification.

Beckingham and Archibald (1996) identified a Calamagrostis canadensis fen type (k.3.2) based on two plots. This was a boreal mixedwood type that was very similar to the current classification. The dominant cover in both types was Calamagrostis canadensis and Carex spp. Calamagrostis inexpansa and Polygonum coccineum were also important to this type but were not recorded in the current classification.

NatureServe (2004) lists a Calamagrostis canadensis Western Herbaceous Vegetation (CEGL001559) that occurred widely throughout mountainous regions of western United States and Canada. It was most common in valley bottom riparian zones where flooding occurred in the spring and the water table stays within $50 \mathrm{~cm}$ to $80 \mathrm{~cm}$ of the ground surface throughout the growing season. Calamagrostis canadensis 
Table 54. Summary of plot data and descriptive statistics for the Calamagrostis canadensis - Potentilla palustris community type $(\mathrm{n}=3)$.

\begin{tabular}{||clccccccc||}
\hline \hline & & \multicolumn{3}{c}{ Plots } & & & \\
\cline { 3 - 6 } Strata & Code & S25 & P48 & P61 & Mean & SE & Constancy & Prominence \\
\hline \hline G & CALACAN Calamagrostis canadensis & 50.0 & 60.0 & 70.0 & 60.0 & 5.8 & 100.0 & 77.5 \\
H & POTEPAL Potentilla palustris & 0.0 & 15.0 & 7.0 & 7.3 & 4.3 & 66.7 & 22.1 \\
H & PETASAG Petasites frigidus var sagittatus & 19.0 & 0.0 & 0.0 & 6.3 & 6.3 & 33.3 & 14.5 \\
M & SPHAMAG Sphagnum magellanicum & 0.0 & 15.0 & 0.0 & 5.0 & 5.0 & 33.3 & 12.9 \\
S3 & SALIBEB Salix bebbiana & 0.0 & 10.0 & 0.0 & 3.3 & 3.3 & 33.3 & 10.5 \\
S3 & SALIPED Salix pedicellaris & 0.0 & 10.0 & 0.0 & 3.3 & 3.3 & 33.3 & 10.5 \\
H & POLYAMP Polygonum amphibium & 0.0 & 0.0 & 9.0 & 3.0 & 3.0 & 33.3 & 10.0 \\
G & CARELAS Carex lasiocarpa & 0.0 & 7.0 & 0.0 & 2.3 & 2.3 & 33.3 & 8.8 \\
H & EQUIFLU Equisetum fluviatile & 4.0 & 0.0 & 0.0 & 1.3 & 1.3 & 33.3 & 6.7 \\
S2 & SALIPYR Salix pyrifolia & 0.0 & 0.0 & 4.0 & 1.3 & 1.3 & 33.3 & 6.7 \\
M & DREPADU Drepanocladus aduncus & 0.0 & 4.0 & 0.0 & 1.3 & 1.3 & 33.3 & 6.7 \\
G & CARECUR Carex canescens & 0.0 & 2.0 & 0.0 & 0.7 & 0.7 & 33.3 & 4.7 \\
H & CALTPAL Caltha palustris & 1.0 & 0.0 & 0.0 & 0.3 & 0.3 & 33.3 & 3.3 \\
G & CAREUTR Carex utriculata & 0.5 & 0.0 & 0.0 & 0.2 & 0.2 & 33.3 & 2.4 \\
G & AGROSCA Agrostis scabra & 0.0 & 0.5 & 0.0 & 0.2 & 0.2 & 33.3 & 2.4 \\
H & SCUTGAL Scutellaria galericulata & 0.0 & 0.1 & 0.0 & 0.0 & 0.0 & 33.3 & 1.1 \\
\hline \hline
\end{tabular}

was the dominant cover type in association with Carex aquatilis and Glyceria spp. Trees such as Pinus contorta, Abies lasiocarpa, and Picea engelmannii may be present with low cover values. Shrub cover was usually $1 \%$ to $5 \%$ and may include Alnus incana, Symphoricarpos spp., and Salix spp. Other species may include Carex utriculata, Carex nebrascensis, Carex canescens and Carex saxatilis. Forb cover was variable ( $0 \%$ to $25 \%)$ and may include Caltha leptosepala, Senecio triangularis, Heracleum maximum, Mentha arvensis, Geum macrophyllum and Epilobium spp. Another similar wetland type listed by NatureServe (2004) was the Calla palustris - Carex canescens - Calamagrostis canadensis Fen Herbaceous Vegetation (CEGL002548). This community was part of the "Carex spp. Saturated Herbaceous Alliance" and was reported to occur in Manitoba. Similarity ratings for related community types are provided in Table 55.

Table 55. Correlation table of plant community types with similarity ratings for the Calamagrostis canadensis - Potentilla palustris type.

\begin{tabular}{||l|c|l||}
\hline \multicolumn{1}{|c|}{ Similar Types } & $\begin{array}{c}\text { Similarity } \\
\text { Rating }\end{array}$ & \multicolumn{1}{c||}{ Comments } \\
\hline \hline $\begin{array}{l}\text { Alnus tenuifolia / Calamagrostis } \\
\text { canadensis CT (Allen and Johnson no } \\
\text { date) }\end{array}$ & 3 & $\begin{array}{l}\text { Possibly a similar type but has a shrub layer dominated } \\
\text { by Alnus tenuifolia. }\end{array}$ \\
\hline $\begin{array}{l}\text { Calamagrostis canadensis CT (pers. } \\
\text { comm. Keith Ainsely 2005) }\end{array}$ & 1 & $\begin{array}{l}\text { Very similar Calamagrostis canadensis CT that } \\
\text { occurred on similar sites and has a similar species } \\
\text { composition. }\end{array}$ \\
\hline $\begin{array}{l}\text { Calamagrostis canadensis fen CT (k.3.2) } \\
\text { (Beckingham and Archibald 1996) }\end{array}$ & $1(2)$ & $\begin{array}{l}\text { Very similar type although no Calamagrostis } \\
\text { inexpansa } \text { was recorded in the current classification. }\end{array}$ \\
\hline $\begin{array}{l}\text { Calamagrostis canadensis Western } \\
\text { Herbaceous Vegetation (CEGL001559) } \\
\text { (NatureServe 2004) }\end{array}$ & $3(2)$ & $\begin{array}{l}\text { Mountain wetland type that occurs in western United } \\
\text { States and Canada. Calamagrostis canadensis was } \\
\text { dominant but there were dissimilarities in floristics. }\end{array}$ \\
\hline $\begin{array}{l}\text { Calla palustris - Carex canescens - } \\
\text { Calamagrostis canadensis Fen } \\
\text { Herbaceous Vegetation (CEGL002548) } \\
\text { (NatureServe 2004) }\end{array}$ & 3 & $\begin{array}{l}\text { This appears to be a wetter type of community but no } \\
\text { details were provided regarding floristics. It occurred } \\
\text { in Manitoba. }\end{array}$ \\
\hline
\end{tabular}




\subsubsection{Poa palustris Herbaceous Vegetation}

Fowl Bluegrass Herbaceous Vegetation

This was a semi-natural type that was sampled in North Buck Lake study area (Table 56). One plot was completed in a narrow band of vegetation ( $2 \mathrm{~m}$ to $5 \mathrm{~m}$ wide) that occurred on the north shore of Big Johnson Lake (i.e. Chump Lake). This site appeared to be flooded seasonally and subjected to wash from wave action. The soils were imperfectly drained with variable moisture levels ranging from subhygric to submesic moving upslope. The nutrient regime was mesotrophic. At the plot sampled, surface substrates were mainly organic matter (77\%), mineral (20\%) and decaying wood $(3 \%)$. This type was recognised by the dominance of Poa palustris and a diversity of other plant species (Table 56). Associated species in the one stand sampled included Salix pseudomonticola, Hippuris vulgaris, Mentha arvensis, Sonchus arvensis, Juncus tenuis, Phalaris arundinacea, Crepis tectorum, Eleocharis palustris and Scirpus acutus. The adjacent emergent zone was $20 \mathrm{~m}$ to $150 \mathrm{~m}$ wide and was dominated by Scirpus acutus, Nuphar lutea, Eleocharis palustris, Sagittaria cuneata and Hippuris vulgaris.

Class: Herbaceous Vegetation

Subclass: Perennial graminoid vegetation

Group: Temperate or subpolar grassland

Subgroup: Natural/Semi-natural temperate or subpolar grassland

Formation: Seasonally flooded temperate or subpolar grassland

Alliance: Poa palustris Semi-natural Seasonally Flooded Herbaceous Alliance

Association: Poa palustris Herbaceous Vegetation

Unique Identifier: A.1409 Alliance

Classification Confidence Level: 3 (Weak) Poa palustris was the dominant species but there was expected to be considerable variability in species composition within this plant community. Only one other similar community type was reviewed. The geographical range of this community was unknown.

\section{Dominant Species: Poa palustris}

Co-Dominant Species: Salix pseudomonticola, Hippuris vulgaris, Mentha arvensis, Sonchus arvensis, Juncus tenuis

Diagnostic Species: Poa palustris

\section{Literature Review:}

Allen et al. (2002) reported a Poa palustris - Calamagrostis stricta community type that occurred in the La Butte Creek Wildland Provincial Park located north of Lake Athabasca. This stand was in an extensive mesic meadow that was apparently located in an old river channel.

NatureServe (2004) lists a Poa palustris Semi-natural Seasonally Flooded Herbaceous Alliance (A.1409) that appears to be very similar to the current classification. It was a semi-natural grassland type that was expected to be widespread. Poa palustris was the dominant species and was often associated with a variety of non-native weedy species. This alliance type occurred on mesic alluvial sites that were commonly seasonally flooded. Similarity ratings for related plant community types are provided in Table 57. 
Table 56. Summary of plot data and descriptive statistics for the Poa palustris Semi-natural Seasonally Flooded Herbaceous Alliance type $(n=1)$.

\begin{tabular}{|c|c|c|c|c|c|c|c|}
\hline \multirow[b]{2}{*}{ Strata } & \multirow[b]{2}{*}{ Code } & \multirow[b]{2}{*}{ Species } & \multirow{2}{*}{$\begin{array}{c}\text { Plot } \\
33 \\
\end{array}$} & \multirow[b]{2}{*}{ Strata } & \multirow[b]{2}{*}{ Code } & \multirow[b]{2}{*}{ Species } & \multirow{2}{*}{$\begin{array}{c}\text { Plot } \\
33 \\
\end{array}$} \\
\hline & & & & & & & \\
\hline G & POAPALU & Poa palustris & 20.0 & $\mathrm{H}$ & GALITRI & Galium trifidum & 0.5 \\
\hline $\mathrm{H}$ & MENTARV & Mentha arvensis & 9.0 & S3 & POPUBAL & Populus balsamifera & 0.5 \\
\hline $\mathrm{H}$ & SONCARV & Sonchus arvensis & 5.0 & $\mathrm{H}$ & POLYLAP & $\begin{array}{l}\text { Polygonum } \\
\text { lapathifolium }\end{array}$ & 0.5 \\
\hline S3 & SALIPSE & Salix pseudomonticola & 5.0 & S3 & BETUPAP & Betula papyrifera & 0.5 \\
\hline G & JUNCDUD & Juncus tenuis & 4.0 & G & CAREAQU & Carex aquatilis & 0.5 \\
\hline $\mathrm{H}$ & HIPPVUL & Hippuris vulgaris & 4.0 & G & HORDJUB & Hordeum jubatum & 0.5 \\
\hline G & PHALARU & Phalaris arundinacea & 2.0 & G & SPHEINT & $\begin{array}{l}\text { Sphenopholis } \\
\text { intermedia }\end{array}$ & 0.5 \\
\hline $\mathrm{H}$ & CREPTEC & Crepis tectorum & 2.0 & $\mathrm{H}$ & POTENOR & Potentilla norvegica & 0.5 \\
\hline G & ELEOPAL & Eleocharis palustris & 2.0 & G & CARECRA & Carex crawfordii & 0.2 \\
\hline G & SCIRACU & Scirpus acutus & 2.0 & G & JUNCNOD & Juncus nevadensis & 0.1 \\
\hline S3 & SALIBEB & Salix bebbiana & 2.0 & S3 & SALIPET & Salix petiolaris & 0.1 \\
\hline G & AGROSCA & Agrostis scabra & 1.0 & S3 & POPUTRE & Populus tremuloides & 0.1 \\
\hline G & ALOPAEQ & Alopecurus aequalis & 1.0 & $\mathrm{H}$ & RUMEMAR & Rumex maritimus & 0.1 \\
\hline $\mathrm{H}$ & PARNPAL & Parnassia parviflora & 0.5 & $\mathrm{H}$ & FRAGVIR & Fragaria virginiana & 0.1 \\
\hline
\end{tabular}

Table 57. Correlation table of plant community types with similarity ratings for the Poa palustris Seminatural Seasonally Flooded Herbaceous Alliance type.

\begin{tabular}{||c|c|c||}
\hline Similar Types & $\begin{array}{c}\text { Similarity } \\
\text { Rating }\end{array}$ & \multicolumn{1}{c||}{ Comments } \\
\hline \hline $\begin{array}{l}\text { Poa palustris - Calamagrostis stricta } \\
\text { CT (Allen } \text { et al. 2002) }\end{array}$ & 3 & $\begin{array}{l}\text { Possibly a related type but no details were available } \\
\text { regarding the species composition of this community. } \\
\text { Current type likely has considerable variability in species } \\
\text { composition. }\end{array}$ \\
\hline
\end{tabular}




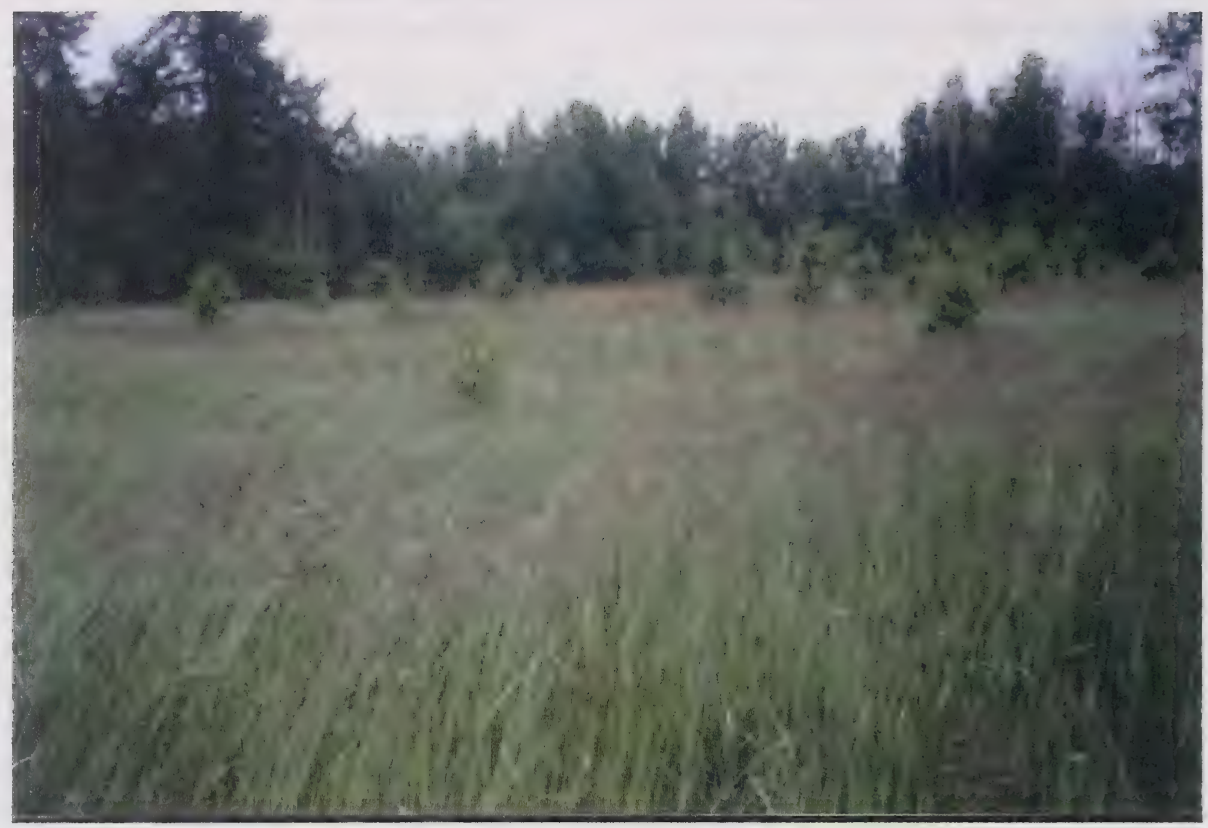

Plate 27. Calamagrostis canadensis - Potentilla palustris Herbaceous Vegetation (P48).

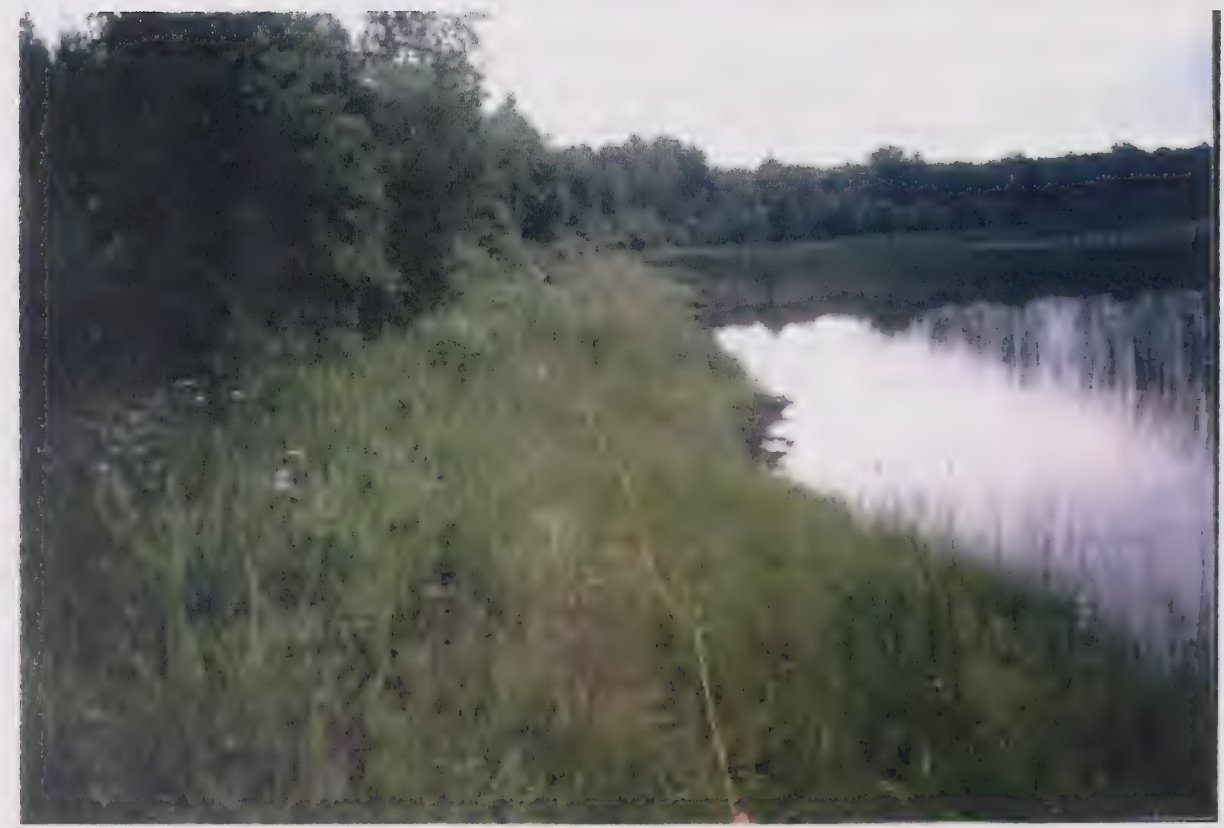

Plate 28. Poa palustris Herbaceous Vegetation (P33). 


\subsubsection{Festuca saximontana - Artemisia campestris Herbaceous Vegetation \\ Rocky Mountain Fescue - Plains Wormweed Herbaceous Vegetation}

The Festuca saximontana - Artemisia campestris Herbaceous Vegetation type was a relatively common type in the North Buck Lake study area but was not observed in the Holmes Crossing Sandhills Ecological Reserve. Stands were small generally under approximately $200 \mathrm{~m}^{2}$ and typically occurred on dune crests or upper slopes. Sites were predominately convex in profile with high insolation values and rapidly to well drained soils. Aspects ranged from southeast to southwest and slopes ranged between $4 \%$ and $21 \%$ gradients with a mean of $4 \%$. The fine sandy soils had subxeric to xeric moisture levels and submesotrophic to mesotrophic nutrient regimes. Surface substrates were largely organic matter (75\%) although a significant amount of exposed mineral soil (25\%) was also typical. Shrub cover was very sparse but included Amelanchier alnifolia, Apocynum androsaemifolium, and Arctostaphylos uva-ursi (Table 58). Dominant cover in this plant community consisted of Artemisia campestris (10\%), Carex siccata (7\%), Cladina mitis (8\%), Cladonia spp. (5\%), and Polytrichum piliferum (5\%). Other important graminoid species included Carex umbellata, Festuca saximontana, Agrostis scabra, Elymus trachycaulus, Danthonia spicata. Selaginella densa occurred at between trace and $2 \%$ cover.

Class: Herbaceous Vegetation

Subclass: Perennial graminoid vegetation

Group: Temperate or subpolar grassland

Subgroup: Natural/Semi-natural temperate or subpolar grassland

Formation: Medium-tall bunch temperate or subpolar grassland

Alliance: Festuca saximontana Herbaceous Alliance

Association: Festuca saximontana - Artemisia campestris Herbaceous Vegetation

Unique Identifier: $\mathrm{n} / \mathrm{a}$

Classification Confidence Level: 2 (Moderate) An easily recognisable type and six plots completed in this type. It was common in the North Buck Lake study area but no identical types were located in the literature. Geographical range was unknown.

Dominant Species: Artemisia campestris, Festuca saximontana, Cladina mitis, Cladonia spp., Polytrichum piliferum

Co-Dominant Species: Selaginella densa, Agrostis scabra, Elymus trachycaulus, Carex siccata, Carex umbellata, Danthonia spicata

Diagnostic Species: Artemisia campestris, Carex siccata, Carex umbellata, Festuca saximontana, Cladina mitis, Polytrichum piliferum

\section{Literature Review:}

Allen and Johnson (no date.) described a Carex siccata Graminoid Slope (CT 7) from Maybelle River Wildland Park. This was a common early successional plant community that was typically occupied southeast to southwest facing mid-slope positions. Slopes were moderately steep (e.g. $20^{\circ}$ ) and soils were rapidly drained with xeric moisture levels. This community had essentially the same species composition as the current classification. However, this type had greater cover of Carex siccata and less cover of Festuca saximontana and Artemisia campestris. Allen and Johnson (no date.) described a Rosa acicularis / Festuca saximontana / Arctostaphylos uva-ursi community type that occurred in the Richardson River Dunes Wildland Park. No details were provided regarding this type other than it occurred as small shrubby openings. Raup and Argus (1982) gave a general description of a plant community that occurred on border ridges of parabolic sand dunes in the Lake Athabasca area. These occurred as small patches of sparse vegetation within Pinus banksiana forest or woodland openings. Typically there was a continuous mat of Polytrichum spp., a high percent cover of open sand, and significant cover of Hudsonia tomentosa. 
Table 58. Summary of plot data and descriptive statistics for the Festuca saximontana - Artemisia campestris community type $(\mathrm{n}=6)$.

\begin{tabular}{|c|c|c|c|c|c|c|c|c|c|c|c|c|}
\hline \multirow[b]{2}{*}{ Strata } & \multirow[b]{2}{*}{ Code } & \multirow[b]{2}{*}{ Species } & \multicolumn{6}{|c|}{ Plots } & \multirow[b]{2}{*}{ Mean } & \multirow[b]{2}{*}{ SE } & \multirow[b]{2}{*}{ Constancy } & \multirow[b]{2}{*}{ Prominence } \\
\hline & & & P39 & P45 & P47 & P53 & P56 & P62 & & & & \\
\hline G & FESTSAX & Festuca saximontana & 10.0 & 16.0 & 4.0 & 17.0 & 10.0 & 5.0 & 10.3 & 2.2 & 100.0 & 32.1 \\
\hline $\mathrm{L}$ & CLADMIT & Cladina mitis & 2.0 & 7.0 & 20.0 & 2.0 & 10.0 & 7.0 & 8.0 & 2.7 & 100.0 & 28.3 \\
\hline $\mathrm{H}$ & ARTECAM & Artemisia campestris & 3.0 & 10.0 & 5.0 & 0.5 & 10.0 & 15.0 & 7.3 & 2.2 & 100.0 & 26.9 \\
\hline $\mathrm{L}$ & CLADONI & Cladonia spp. & 5.0 & 2.0 & 0.0 & 0.5 & 0.0 & 25.0 & 5.4 & 4.0 & 66.7 & 19.0 \\
\hline M & POLYPIL & Polytrichum piliferum & 0.0 & 6.0 & 0.0 & 1.0 & 1.0 & 20.0 & 4.7 & 3.2 & 66.7 & 17.6 \\
\hline G & CARESIC & Carex siccata & 8.0 & 0.1 & 0.1 & 1.0 & 2.0 & 2.0 & 2.2 & 1.2 & 100.0 & 14.8 \\
\hline G & AGROSCA & Agrostis scabra & 0.0 & 1.0 & 0.0 & 0.1 & 4.0 & 0.1 & 0.9 & 0.6 & 66.7 & 7.6 \\
\hline G & CAREUMB & Carex umbellata & 0.5 & 0.5 & 0.5 & 0.0 & 1.0 & 0.5 & 0.5 & 0.1 & 83.3 & 6.5 \\
\hline G & DANTSPI & Danthonia spicata & 3.0 & 4.0 & 0.0 & 0.0 & 0.0 & 0.0 & 1.2 & 0.7 & 33.3 & 6.2 \\
\hline G & ELYMTRA & Elymus trachycaulus & 2.0 & 0.0 & 0.0 & 0.5 & 0.0 & 0.1 & 0.4 & 0.3 & 50.0 & 4.7 \\
\hline $\mathrm{H}$ & SELADEN & Selaginella densa & 0.0 & 0.0 & 2.0 & 0.5 & 0.0 & 0.1 & 0.4 & 0.3 & 50.0 & 4.7 \\
\hline G & POAPRAT & Poa pratensis & 6.0 & 0.0 & 0.0 & 0.0 & 0.0 & 0.0 & 1.0 & 1.0 & 16.7 & 4.1 \\
\hline $\mathrm{L}$ & CLADUNC & Cladonia uncialis & 0.0 & 0.0 & 0.0 & 0.0 & 0.1 & 2.0 & 0.4 & 0.3 & 33.3 & 3.4 \\
\hline M & MOSSES\$\$ & Moss spp. & 0.0 & 0.0 & 0.0 & 0.5 & 1.0 & 0.0 & 0.3 & 0.2 & 33.3 & 2.9 \\
\hline $\mathrm{H}$ & STELLON & Stellaria longipes & 1.0 & 0.5 & 0.0 & 0.0 & 0.0 & 0.0 & 0.3 & 0.2 & 33.3 & 2.9 \\
\hline $\mathrm{H}$ & CREPTEC & Crepis tectorum & 0.5 & 0.0 & 0.1 & 0.0 & 0.0 & 0.1 & 0.1 & 0.1 & 50.0 & 2.4 \\
\hline S3 & AMELALN & Amelanchier alnifolia & 2.0 & 0.0 & 0.0 & 0.0 & 0.0 & 0.0 & 0.3 & 0.3 & 16.7 & 2.4 \\
\hline $\mathrm{H}$ & SOLISPA & Solidago spathulata & 0.0 & 2.0 & 0.0 & 0.0 & 0.0 & 0.0 & 0.3 & 0.3 & 16.7 & 2.4 \\
\hline G & ORYZPUN & Oryzopsis pungens & 0.0 & 0.0 & 0.0 & 0.0 & 2.0 & 0.0 & 0.3 & 0.3 & 16.7 & 2.4 \\
\hline $\mathrm{H}$ & APOCAND & Apocynum androsaemifolium & 2.0 & 0.0 & 0.0 & 0.0 & 0.0 & 0.0 & 0.3 & 0.3 & 16.7 & 2.4 \\
\hline S3 & ARCTUVA & Arctostaphylos uva-ursi & 1.5 & 0.0 & 0.0 & 0.0 & 0.0 & 0.0 & 0.3 & 0.2 & 16.7 & 2.0 \\
\hline $\mathrm{H}$ & EQUILAE & Equisetum laevigatum & 0.0 & 0.0 & 0.1 & 0.5 & 0.0 & 0.0 & 0.1 & 0.1 & 33.3 & 1.8 \\
\hline $\mathrm{H}$ & ARABDIV & Arabis divaricarpa & 0.0 & 0.0 & 0.0 & 0.0 & 0.5 & 0.0 & 0.1 & 0.1 & 16.7 & 1.2 \\
\hline $\mathrm{L}$ & PELTIGE & Peltigera sp. & 0.0 & 0.5 & 0.0 & 0.0 & 0.0 & 0.0 & 0.1 & 0.1 & 16.7 & 1.2 \\
\hline G & POAINTE & Poa interior & 0.0 & 0.0 & 0.0 & 0.0 & 0.5 & 0.0 & 0.1 & 0.1 & 16.7 & 1.2 \\
\hline $\mathrm{L}$ & CLADBEL & Cladonia bellidiflora & 0.0 & 0.0 & 0.0 & 0.1 & 0.0 & 0.1 & 0.0 & 0.0 & 33.3 & 1.1 \\
\hline $\mathrm{H}$ & ARABLYR & Arabis lyrata & 0.0 & 0.0 & 0.0 & 0.1 & 0.0 & 0.0 & 0.0 & 0.0 & 16.7 & 0.5 \\
\hline
\end{tabular}

Associate plant species included Festuca saximontana, Salix bebbiana, Betula papyrifera, Prunus pensylvanica, and Arctostaphylos uva-ursi. Similarity ratings for related plant community types are provided in Table 59.

Table 59. Correlation table of plant community types with similarity ratings for the Festuca saximontana Artemisia campestris type.

\begin{tabular}{||l|c|l||}
\hline \multicolumn{1}{|c|}{ Similar Types } & $\begin{array}{c}\text { Similarity } \\
\text { Rating }\end{array}$ & \multicolumn{1}{|c||}{ Comments } \\
\hline \hline $\begin{array}{l}\text { Rosa acicularis / Festuca } \\
\text { saximontana / Arctostaphylos uva- } \\
\text { ursi CT (Allen and Johnson no date) }\end{array}$ & $3(2)$ & $\begin{array}{l}\text { This may be a similar type although no further details } \\
\text { were provided regarding species composition and } \\
\text { percent cover values. }\end{array}$ \\
\hline $\begin{array}{l}\text { Carex siccata CT (Allen and Johnson } \\
\text { no date.) }\end{array}$ & 2 & $\begin{array}{l}\text { A very similar community type however cover values of } \\
\text { the dominant species was considerably different. }\end{array}$ \\
\hline $\begin{array}{l}\text { Polytrichum spp. - Hudsonia } \\
\text { tomentosa Sparse Vegetation Type } \\
\text { (Raup and Argus 1982) }\end{array}$ & 3 & $\begin{array}{l}\text { Type has similar ecological site characteristics and has } \\
\text { some plant species in common. However it inhabits } \\
\text { active sand dunes and there were significant differences } \\
\text { in dominant plant species composition. }\end{array}$ \\
\hline
\end{tabular}




\title{
3.3.3.6 Carex siccata - Danthonia spicata Herbaceous Vegetation
}

\author{
Hay Sedge - Poverty Oat Grass Herbaceous Vegetation
}

The Carex siccata - Danthonia spicata Herbaceous Vegetation type occurred as small stands under approximately $200 \mathrm{~m}^{2}$. It was a relatively common and distinctive type in the North Buck Lake study area but not in the Holmes Crossing Sandhills Ecological Reserve. Four plots were completed in this type and these typically occurred on convex to straight sites in upper slope or occasionally mid-slope positions. Slope gradients averaging $11 \%$ and ranged between $7 \%$ and $21 \%$. Vegetation on these sites may be affected by insolation, although aspects were variable with two of the four plots facing southeast, one facing east and one southwest. Soils were rapidly to well drained with predominately subxeric moisture levels and mesotrophic to submesotrophic nutrient regimes. Surface substrate cover was mostly organic (92\%), although there was often significant cover of exposed mineral soil (8\%) and traces of decaying wood. This community was identified by the dominance and constant presence of Carex siccata, Danthonia spicata, and Cladina mitis (Table 60). This was a relatively diverse community and other important plant and lichen species included Artemisia campestris, Stellaria longipes, Elymus trachycaulus, Festuca saximontana, and Cladonia spp. The shrub layer was sparse but included scattered cover of Apocynum androsaemifolium, Arctostaphylos uva-ursi, Prunus pensylvanica, and Populus tremuloides.

Class: Herbaceous Vegetation

Subclass: Perennial graminoid vegetation

Group: Temperate or subpolar grassland

Subgroup: Natural/Semi-natural temperate or subpolar grassland

Formation: Short sod temperate or subpolar grassland

Alliance: Carex siccata Herbaceous Alliance

Association: Carex siccata - Danthonia spicata Herbaceous Vegetation

Unique Identifier: $n / a$

Classification Confidence Level: 2 (Moderate) An easily recognisable community and 4 plots were completed for the type. It appears to be relatively common in the North Buck Lake study area but its geographical range was unknown.

Dominant Species: Carex siccata, Danthonia spicata, Cladina mitis

Co-Dominant Species: Artemisia campestris, Stellaria longipes, Elymus trachycaulus, Festuca saximontana, Cladonia spp.

Diagnostic Species: Carex siccata, Danthonia spicata, Festuca saximontana

\section{Literature Review:}

Allen et al. (2004) identified a Carex siccata graminoid slope type that occurred in the Colin-Cornwall Lakes Wildland Provincial Park in northeastern Alberta. This community was often interspersed with patches of juniper and deciduous woodlands. It typically developed on steep south to southwest-facing slopes of sandy and gravely glacial deposits. The current type also was located on sandy soils, however, typically they occurred on more gentle slopes. This community and the current classification have a relatively good correlation of species, although this community does not include any presence of Danthonia spicata.

NatureServe (2004) lists a Schizachyrium scoparium - Danthonia spicata - Carex pensylvanica - (Viola pedata) Herbaceous Vegetation (CEGL002318). This community type was widespread throughout extending from Indiana, Michigan and southern Ontario, west to Iowa and east-central Minnesota. It was a dry sand prairie community that occurred on steep slopes, sandy outwash, sandy lake plains, and alluvial deposits. Sometimes it was found on sand ridges, sand dunes and sandy areas of coarse-textured end moraines. The herb/graminoid was dominated by graminoids including Carex pensylvanica, Danthonia 
Table 60. Summary of plot data and descriptive statistics for the Carex siccata-Danthonia spicata community type $(n=4)$.

\begin{tabular}{|c|c|c|c|c|c|c|c|c|c|c|}
\hline \multirow[b]{2}{*}{ Strata } & \multirow[b]{2}{*}{ Code } & \multirow[b]{2}{*}{ Species } & \multicolumn{4}{|c|}{ Plots } & \multirow[b]{2}{*}{ Mean } & \multirow[b]{2}{*}{ SE } & \multirow[b]{2}{*}{ Constancy } & \multirow[b]{2}{*}{ Prominence } \\
\hline & & & P38 & P44 & P49 & P63 & & & & \\
\hline G & CARESIC & Carex siccata & 10.0 & 3.0 & 40.0 & 15.0 & 17.0 & 8.1 & 100.0 & 41.2 \\
\hline $\mathrm{L}$ & CLADMIT & Cladina mitis & 0.0 & 50.0 & 20.0 & 10.0 & 20.0 & 10.8 & 75.0 & 38.7 \\
\hline G & DANTSPI & Danthonia spicata & 1.0 & 6.0 & 6.0 & 30.0 & 10.8 & 6.5 & 100.0 & 32.8 \\
\hline $\mathrm{H}$ & ARTECAM & Artemisia campestris & 0.0 & 0.5 & 4.0 & 5.0 & 2.4 & 1.2 & 75.0 & 13.3 \\
\hline $\mathrm{H}$ & STELLON & Stellaria longipes & 1.0 & 0.5 & 3.0 & 0.5 & 1.3 & 0.6 & 100.0 & 11.2 \\
\hline G & FESTSAX & Festuca saximontana & 0.5 & 2.0 & 2.0 & 0.5 & 1.3 & 0.4 & 100.0 & 11.2 \\
\hline G & ELYMTRA & Elymus trachycaulus & 2.0 & 0.0 & 5.0 & 0.0 & 1.8 & 1.2 & 50.0 & 9.4 \\
\hline $\mathrm{L}$ & CLADONI & Cladonia spp. & 0.0 & 0.0 & 4.0 & 2.0 & 1.5 & 1.0 & 50.0 & 8.7 \\
\hline $\mathrm{L}$ & CLADUNC & Cladonia uncialis & 0.0 & 0.5 & 0.5 & 2.0 & 0.8 & 0.4 & 75.0 & 7.5 \\
\hline $\mathrm{H}$ & APOCAND & Apocynum androsaemifolium & 5.0 & 0.0 & 0.0 & 0.0 & 1.3 & 1.3 & 25.0 & 5.6 \\
\hline $\mathrm{L}$ & CLADGRA & Cladonia gracilis & 0.0 & 0.0 & 0.0 & 4.0 & 1.0 & 1.0 & 25.0 & 5.0 \\
\hline S3 & PRUNPEN & Prunus pensylvanica & 4.0 & 0.0 & 0.0 & 0.0 & 1.0 & 1.0 & 25.0 & 5.0 \\
\hline S3 & ARCTUVA & Arctostaphylos uva-ursi & 0.0 & 0.0 & 0.0 & 4.0 & 1.0 & 1.0 & 25.0 & 5.0 \\
\hline S3 & AMELALN & Amelanchier alnifolia & 4.0 & 0.0 & 0.0 & 0.0 & 1.0 & 1.0 & 25.0 & 5.0 \\
\hline S3 & POPUTRE & Populus tremuloides & 0.0 & 0.0 & 0.0 & 2.0 & 0.5 & 0.5 & 25.0 & 3.5 \\
\hline $\mathrm{L}$ & PELTMAL & Peltigera malacea & 0.0 & 0.0 & 0.0 & 2.0 & 0.5 & 0.5 & 25.0 & 3.5 \\
\hline M & POLYPIL & Polytrichum piliferum & 0.0 & 0.1 & 0.0 & 0.5 & 0.2 & 0.1 & 50.0 & 2.7 \\
\hline $\mathrm{H}$ & CREPTEC & Crepis tectorum & 0.1 & 0.0 & 0.1 & 0.1 & 0.1 & 0.0 & 75.0 & 2.4 \\
\hline $\mathrm{H}$ & VIOLADU & Viola adunca & 0.5 & 0.0 & 0.0 & 0.0 & 0.1 & 0.1 & 25.0 & 1.8 \\
\hline $\mathrm{H}$ & ASTELAE & Aster laevis & 0.0 & 0.0 & 0.0 & 0.5 & 0.1 & 0.1 & 25.0 & 1.8 \\
\hline G & POAPRAT & Poa pratensis & 0.0 & 0.5 & 0.0 & 0.0 & 0.1 & 0.1 & 25.0 & 1.8 \\
\hline G & POAINTE & Poa interior & 0.0 & 0.5 & 0.0 & 0.0 & 0.1 & 0.1 & 25.0 & 1.8 \\
\hline $\mathrm{L}$ & PELTIGE & Peltigera sp. & 0.0 & 0.5 & 0.0 & 0.0 & 0.1 & 0.1 & 25.0 & 1.8 \\
\hline S3 & ROSAACI & Rosa acicularis & 0.0 & 0.0 & 0.0 & 0.5 & 0.1 & 0.1 & 25.0 & 1.8 \\
\hline $\mathrm{H}$ & EQUILAE & Equisetum laevigatum & 0.0 & 0.0 & 0.5 & 0.0 & 0.1 & 0.1 & 25.0 & 1.8 \\
\hline $\mathrm{H}$ & SOLISPA & Solidago spathulata & 0.0 & 0.5 & 0.0 & 0.0 & 0.1 & 0.1 & 25.0 & 1.8 \\
\hline $\mathrm{H}$ & EQUIARV & Equisetum arvense & 0.0 & 0.0 & 0.0 & 0.5 & 0.1 & 0.1 & 25.0 & 1.8 \\
\hline M & MOSSES\$S & Moss spp. & 0.0 & 0.0 & 0.0 & 0.1 & 0.0 & 0.0 & 25.0 & 0.8 \\
\hline S2 & POPUTRE & Populus tremuloides & 0.1 & 0.0 & 0.0 & 0.0 & 0.0 & 0.0 & 25.0 & 0.8 \\
\hline G & AGROSCA & Agrostis scabra & 0.0 & 0.1 & 0.0 & 0.0 & 0.0 & 0.0 & 25.0 & 0.8 \\
\hline $\mathrm{H}$ & HUDSTOM & Hudsonia tomentosa & 0.0 & 0.1 & 0.0 & 0.0 & 0.0 & 0.0 & 25.0 & 0.8 \\
\hline $\mathrm{L}$ & CLADBEL & Cladonia bellidiflora & 0.0 & 0.0 & 0.0 & 0.1 & 0.0 & 0.0 & 25.0 & 0.8 \\
\hline
\end{tabular}

spicata, Koeleria macrantha, Schizachyrium scoparium, and Hesperostipa spartea (= Stipa spartea). Other graminoids include Bouteloua hirsuta, Digitaria cognata (= Leptoloma cognatum), Dichanthelium acuminatum var. fasciculatum (= Dichanthelium lanuginosum) and sometimes Calamovilfa longifolia . Common forbs include Asclepias verticillata, Ambrosia psilostachya, Artemisia frigida,

Pseudognaphalium obtusifolium (= Gnaphalium obtusifolium), Euphorbia corollata, Hieracium longipilum, Lechea tenuifolia, Liatris aspera, Liatris cylindracea, Nuttallanthus canadensis (= Linaria canadensis), Lithospermum canescens, Lupinus perennis, Oenothera rhombipetala, Polygala polygama, Packera plattensis (= Senecio plattensis), Solidago nemoralis, Tephrosia virginiana and Viola pedata. On blowouts and open exposed sand areas Hudsonia tomentosa was often present. Similarity ratings for related plant community types are provided in Table 61. 
Table 61. Correlation table of plant community types with similarity ratings for the Carex siccataDanthonia spicata type.

\begin{tabular}{||l|c|l||}
\hline \multicolumn{1}{|c|}{ Similar Types } & $\begin{array}{c}\text { Similarity } \\
\text { Rating }\end{array}$ & \multicolumn{1}{c||}{ Comments } \\
\hline $\begin{array}{l}\text { Carex siccata graminoid slope type } \\
\text { (Allen et al. 2004) }\end{array}$ & 2 & $\begin{array}{l}\text { Similar community type that occurred on steeper slopes. } \\
\text { This type does not include Danthonia spicata as a } \\
\text { dominant species. }\end{array}$ \\
\hline $\begin{array}{l}\text { Schizachyrium scoparium - } \\
\text { Danthonia spicata } \text { - Carex } \\
\text { pensylvanica } \text { - (Viola pedata) } \\
\text { Herbaceous Vegetation } \\
\text { (CEGL002318) NatureServe (2004) }\end{array}$ & 3 & $\begin{array}{l}\text { Appears to be a distantly related type occupying a } \\
\text { similar ecological niche but there were many differences } \\
\text { in floristics and the known range does not extend west of } \\
\text { Ontario. }\end{array}$ \\
\hline
\end{tabular}




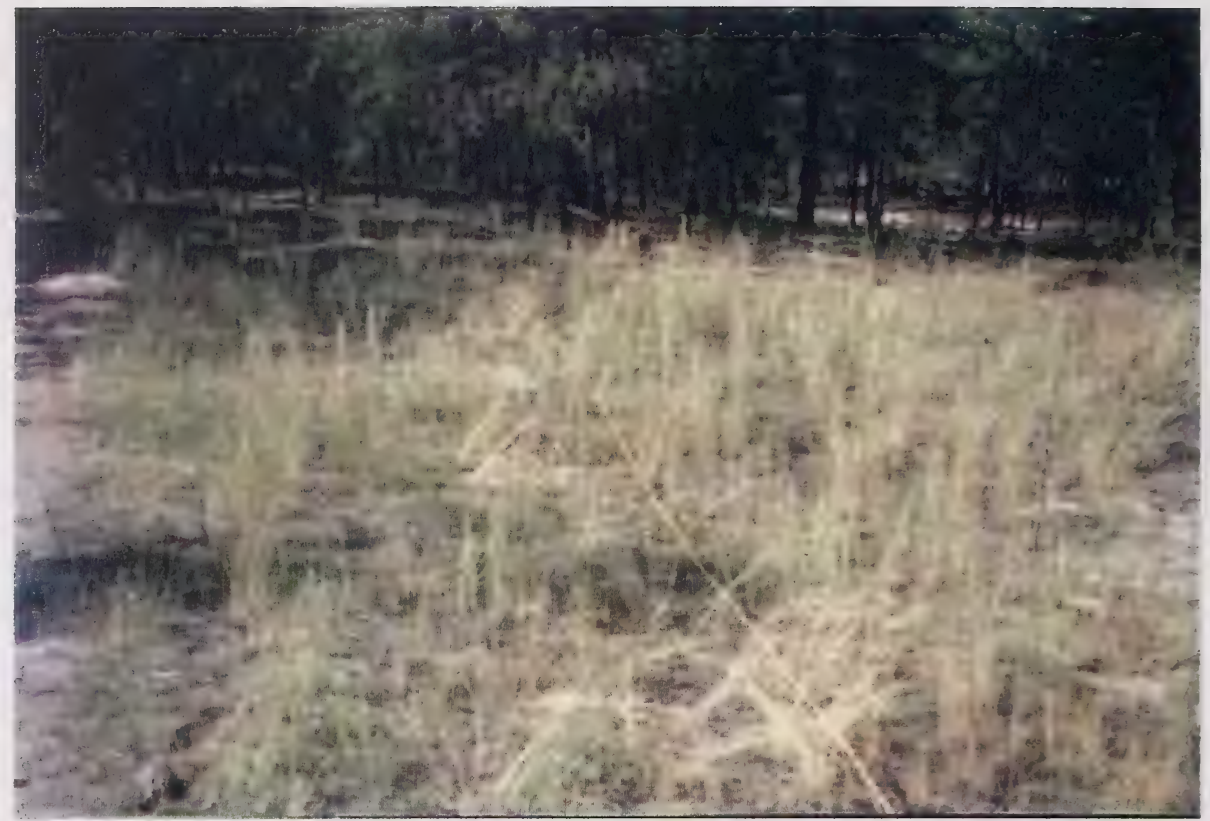

Plate 29. Festuca saximontana - Artemisia campestris Herbaceous Vegetation (P45).

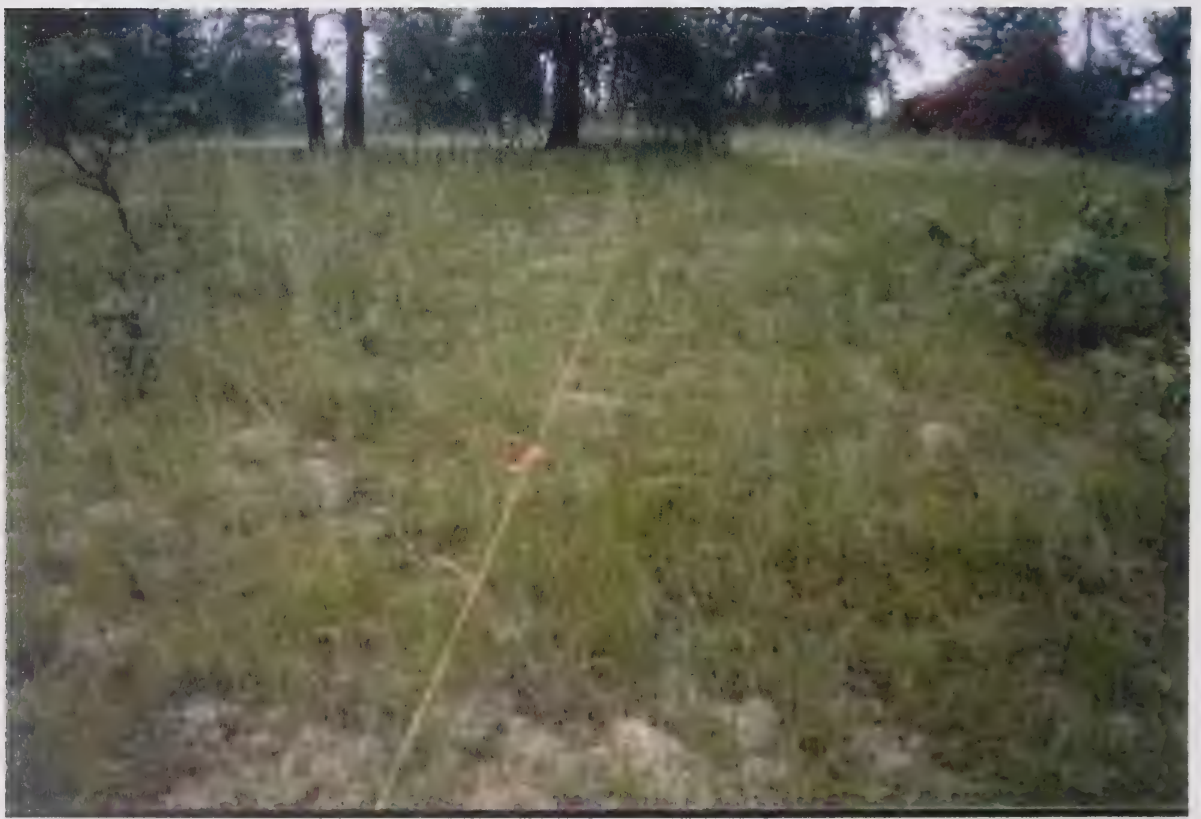

Plate 30. Carex siccata - Danthonia spicata Herbaceous Vegetation (P49). 


\subsubsection{Elymus trachycaulus - Carex pensylvanica - Selaginella densa Herbaceous Vegetation Slender Wheat Grass - Sun-Loving Sedge - Prairie Selaginella Herbaceous Vegetation}

This was not a common type and only one example of it was encountered in Holmes Crossing Sandhills Ecological Reserve (Table 62). This stand was located on a mid-slope position with a convex profile, south aspect, and slope gradient of $28 \%$. This site was subjected to high levels of insolation and had well drained sandy soils with submesic moisture levels, and a mesotrophic nutrient regime. Surface substrate cover was largely organic matter $(90 \%)$, although exposed mineral soil $(10 \%)$ was also prevalent. Shrub cover was limited to small patches of Arctostaphylos uva-ursi (4\%). Dominant cover in the herbaceous layer consisted of Elymus trachycaulus (30\%), Carex pensylvanica (10\%), and Selaginella densa (6\%). Other important species may include Anemone multifida, Aster laevis, Galium boreale, Solidago spathulata, Carex siccata, Carex umbellata, and Festuca saximontana.

Class: Herbaceous Vegetation

Subclass: Perennial graminoid vegetation

Group: Temperate or subpolar grassland

Subgroup: Natural/Semi-natural temperate or subpolar grassland

Formation: Medium-tall sod temperate or subpolar grassland

Alliance: Elymus trachycaulus Herbaceous Alliance

Association: Elymus trachycaulus - Carex pensylvanica - Selaginella densa Herbaceous Vegetation Unique Identifier: $n / a$

Classification Confidence Level: 3 (Weak) Only one stand was encountered and there was limited reference to similar types in the literature. Geographical range of this type was not known.

Dominant Species: Elymus trachycaulus, Carex pensylvanica, Selaginella densa,

Co-Dominant Species: Arctostaphylos uva-ursi, Anemone multifida, Aster laevis, Galium boreale,

Solidago spathulata, Carex siccata, Carex umbellata, Festuca saximontana

Diagnostic Species: Elymus trachycaulus, Carex pensylvanica, Selaginella densa

Table 62. Summary of plot data and descriptive statistics for the Elymus trachycaulus - Carex pensylvanica - Selaginella densa Herbaceous Vegetation community type $(n=1)$.

\begin{tabular}{|cllc|}
\hline & & & Plot \\
\cline { 4 - 4 } Strata & \multicolumn{1}{c}{ Code } & \multicolumn{1}{c}{ Species } & P11 \\
\hline G & ELYMTRA & Elymus trachycaulus & 30.0 \\
G & CAREPEN & Carex pensylvanica & 10.0 \\
H & SELADEN & Selaginella densa & 6.0 \\
G & CAREUMB & Carex umbellata & 5.0 \\
G & CARESIC & Carex siccata & 4.0 \\
G & FESTSAX & Festuca saximontana & 4.0 \\
S3 & ARCTUVA & Arctostaphylos uva-ursi & 4.0 \\
H & GALIBOR & Galium boreale & 3.0 \\
\hline
\end{tabular}

\begin{tabular}{|c|c|c|c|}
\hline & & & Plot \\
\hline Strata & Code & Species & P11 \\
\hline $\mathrm{H}$ & SOLISPA & Solidago spathulata & 2.0 \\
\hline $\mathrm{H}$ & ASTELAE & Aster laevis & 2.0 \\
\hline $\mathrm{H}$ & ASTRROB & Astragalus robbinsii & 2.0 \\
\hline $\mathrm{H}$ & ANEMMUL & Anemone multifida & 0.5 \\
\hline $\mathrm{L}$ & CLADMIT & Cladina mitis & 0.5 \\
\hline $\mathrm{H}$ & EQUIHYE & Equisetum hyemale & 0.5 \\
\hline $\mathrm{H}$ & ANDRSEP & $\begin{array}{l}\text { Androsace } \\
\text { septentrionalis }\end{array}$ & 0.1 \\
\hline M & POLYPIL & Polytrichum piliferum & 0.1 \\
\hline
\end{tabular}

\section{Literature Review:}

Timoney and Robinson (1998) noted an Elymus trachycaulus / Arctostaphylos uva-ursi grassland type existing in Ft. Assiniboine Sandhills Wildland Park that was successional to aspen forest. It was found on 
subxeric grassy sand dunes. They reported that this grassland was sporadic but widespread throughout the parkland and boreal forest and was often found in association with hairy wild rye, and sometimes Stipa spp.

Allen (2004) lists an Elymus trachycaulus - Koeleria macrantha that occupies level salt plains in the Peace River Lowlands Subregion. Soils were moderately well to rapidly drained with mostly subxeric moisture regimes. Elymus trachycaulus and Koeleria macrantha were dominant plant species and other co-dominants include Juniperus horizontalis, Hierochloe odorata, Deschampsia caespitosa, Danthonia intermedia, Schizachne purpurascens and Agrostis scabra. Other plant species recorded in the Wood Buffalo National Park area included Helictotrichon hookeri, Carex pensylvanica, Bromus inermis, Artemisia frigida, Stipa curtiseta, Muhlenbergia richardsonis, Festuca scabrella, and Carex obtusata. Allen et al. (2002) reported an Arctostaphylos uva-ursi - Elymus trachycaulus Dwarf-shrubland that occurred in the La Butte Creek Wildland Provincial Park located north of Lake Athabasca. This type was found on the top of an eroded steep slope consisting of coarse sand and gravel with cobbles. Cover of Arctostaphylos uva-ursi was $80 \%$ and cover of Elymus trachycaulus was 7\%. This type shared few other species in common with the current type and no Carex pensylvanica or Selaginella densa was recorded at the one plot completed in the Park. Similarity ratings for related plant community types are provided in Table 63.

Vujnovic and Bentz (2001) reported that the Elymus trachycaulus type was widespread throughout the province and was found in the grassland, montane, foothills and boreal regions. The authors reviewed a number of studies from various ecoregions identifying Elymus trachycaulus dominated communities from both within and outside the province. In reviewing these types there appears to be a larger degree of variation in the plant species composition. Types reported for the boreal forest appeared most similar but these did not include Carex pensylvanica, Selaginella densa, or most of the other species found in the Holmes Crossing study area plot.

Wildlands Ecological Consulting Ltd. (2004) reported an Elymus trachycaulus community that occurred as a small band of homogenous vegetation in a riparian zone in Writing-on-Stone Provincial Park. This stand had $50 \%$ to $75 \%$ cover of Elymus trachycaulus. Other species noted adjacent to this type were Glycyrrhiza lepidota, Hordeum jubatum, and X agrohordeum macounii. Soils were moderately well drained with mesic moisture levels and a mesotrophic nutrient regime.

Table 63. Correlation table of plant community types with similarity ratings for the Elymus trachycaulus Carex pensylvanica - Selaginella densa type.

\begin{tabular}{||l|c|l||}
\hline \multicolumn{1}{|c|}{ Similar Types } & $\begin{array}{c}\text { Similarity } \\
\text { Rating }\end{array}$ & \multicolumn{1}{c|}{ Comments } \\
\hline \hline $\begin{array}{l}\text { Elymus trachycaulus CT (Timoney } \\
\text { and Robinson 1998) }\end{array}$ & $1(2)$ & $\begin{array}{l}\text { Based on the proximity of the study areas and brief } \\
\text { description of this grassland type it appears to be the } \\
\text { same community. No detailed floristic data was } \\
\text { available for review. }\end{array}$ \\
\hline $\begin{array}{l}\text { Elymus trachycaulus } \text { - Koeleria } \\
\text { macrantha CT (CEAB000150) } \\
\text { (Allen 2004) }\end{array}$ & 2 & $\begin{array}{l}\text { Considerable differences in floristics although the } \\
\text { Elymus trachycaulus was a dominant and Carex } \\
\text { pensylvanica } \text { appears to be an associate species. }\end{array}$ \\
\hline $\begin{array}{l}\text { Elymus trachycaulus CT (Vujnovic } \\
\text { and Bentz 2001) }\end{array}$ & 3 & $\begin{array}{l}\text { Elymus trachycaulus was the dominant species but there } \\
\text { was a large variation in species composition. }\end{array}$ \\
\hline $\begin{array}{l}\text { Elymus trachycaulus CT (Wildlands } \\
\text { Ecological Consulting Ltd. 2004) }\end{array}$ & 3 & $\begin{array}{l}\text { Type was dominated by Elymus trachycaulus but there } \\
\text { were important differences in species composition and in } \\
\text { ecological site conditions. }\end{array}$ \\
\hline
\end{tabular}




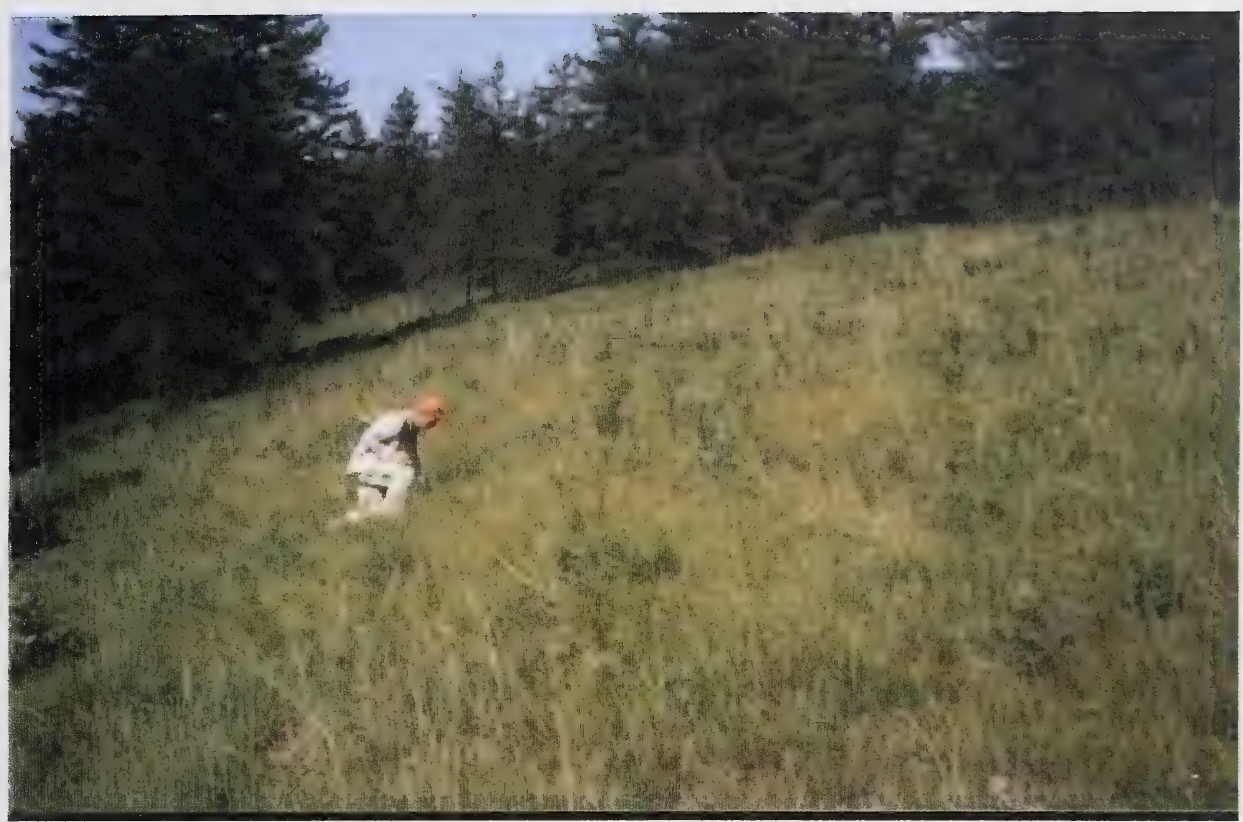

Plate 31. Elymus trachycaulus - Carex pensylvanica - Selaginella densa Herbaceous Vegetation (P11). 


\subsection{CONCLUSION}

A sampling protocol was developed to collect floristics data on plant communities of the sand dunes and sand plains occurring in the Holmes Crossing Sandhills Ecological Reserve and North Buck Lake proposed provincial park and natural area. These study areas were selected by Resource Data Branch of Alberta Sustainable Resource Development, for their eolian landforms representative of the Boreal Central Mixedwood and Dry Boreal Mixedwood Natural Subregions, respectively. In forested and shrublands communities a nested plot was used to sample tree, shrub and herbaceous vegetation. In grassland dominated communities a series of Daubenmire plots were completed along transects. Sampling protocols adhered to the Ecological Land Survey Site (Alberta Sustainable Resource Development 2003).

There was a frequent transition from upland to lowland sites resulted in a wide range of site positions, aspects, slope gradients, soil moisture levels, and nutrient regimes. This variation in ecological site conditions was reflected in the diversity of plant community types that were identified. Table 64 provides a summary of the 31 plant communities recorded, including 17 upland and 14 lowland types. Upland plant community types included 11 forest, 3 shrubland, and 3 herbaceous vegetation types. Lowland communities included 6 forest, 4 shrubland, and 4 herbaceous vegetation types. Many of the plant community types identified were also reported to occur in other areas of the boreal forest or parkland. Applying Corns (1983) similarity rating system to correlate plant community types there were a total of 17 previously described or closely related types (i.e. rating 1), and 14 new or poorly correlated types. Communities that are expected to be closely associated with eolian landforms include:

- Pinus banksiana / Alnus viridis - Vaccinium myrtilloides / Oryzopsis pungens Forest

- Pinus banksiana / Arctostaphylos uva-ursi / Apocynum androsaemifolium Forest

- Pinus banksiana / Cladina mitis Forest

- Populus tremuloides / Vaccinium myrtilloides / Arctostaphylos uva-ursi Forest

- Betula papyrifera - Pinus banksiana / Alnus incana spp. tenuifolia / Aralia nudicaulis Forest

- Amelanchier alnifolia / Arctostaphylos uva-ursi / Oryzopsis pungens Dwarf-shrubland

- Arctostaphylos uva-ursi / Calamovilfa longifolia Dwarf-shrubland

- Amelanchier alnifolia / Arctostaphylos uva-ursi / Oryzopsis pungens Dwarf-shrubland

- Arctostaphylos uva-ursi / Calamovilfa longifolia Dwarf-shrubland

- Festuca saximontana - Artemisia campestris Herbaceous Vegetation

- Carex siccata - Danthonia spicata Herbaceous Vegetation

- Elymus trachycaulus - Carex pensylvanica - Selaginella densa Herbaceous Vegetation

As indicated by the "Classification Confidence Level" rating and the plant community "Similarity Ratings" many of the communities identified in Table 64 are not well defined and are considered tentative types. Further sampling is recommended to more accurately characterise these and to identify other recurring types associated with eolian landforms. In addition, further literature review may assist in describing these plant community types or identifying other similar types. 


\begin{tabular}{|c|c|c|c|}
\hline$\frac{5}{2}$ & 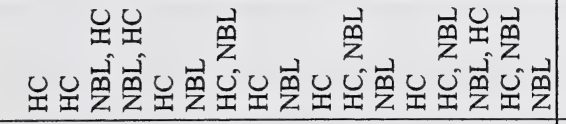 & 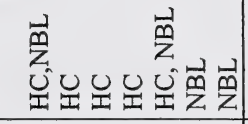 & 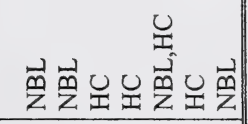 \\
\hline : & 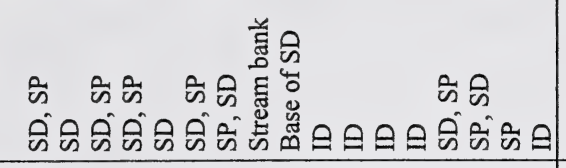 & 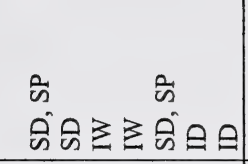 & 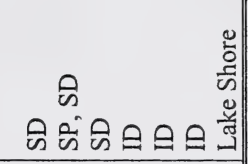 \\
\hline 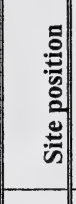 & 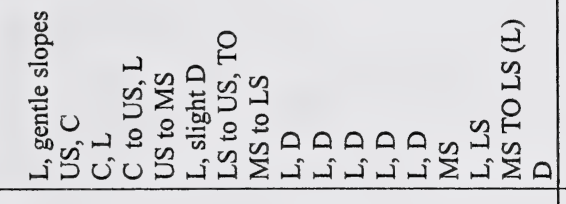 & 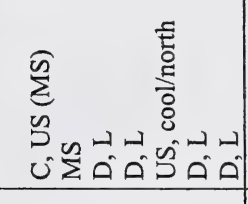 & 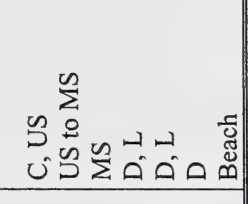 \\
\hline $\begin{array}{l}3 \\
\mathrm{z}\end{array}$ & & & \\
\hline 密: & NAN & & \\
\hline 衰㩆 & & & \\
\hline & 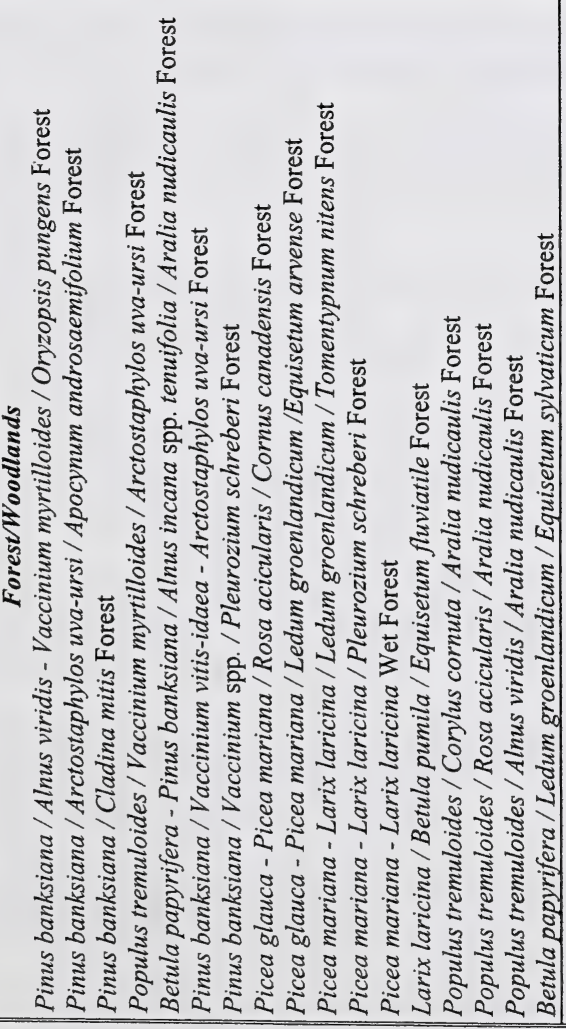 & 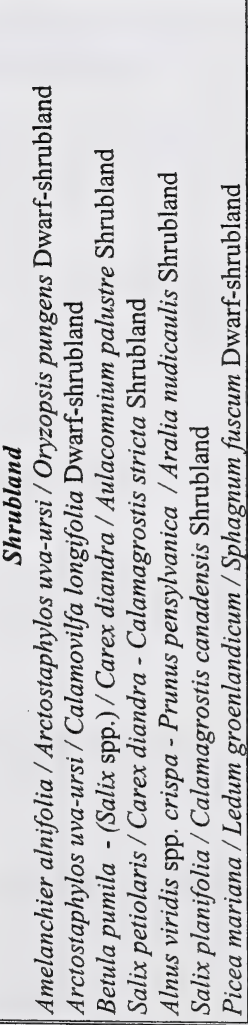 & 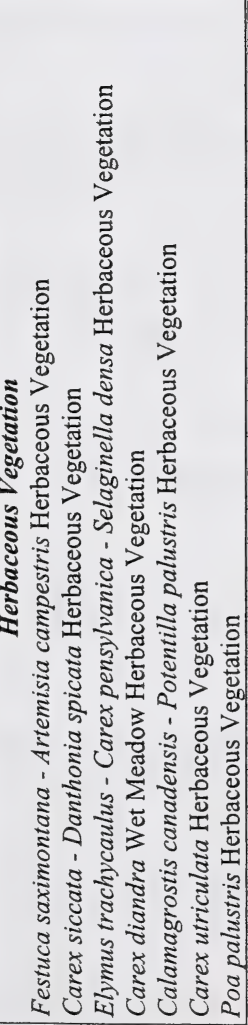 \\
\hline
\end{tabular}



Adams, G.D., G.C. Trottier, W.L. Strong, I.D. MacDonald, S.J. Barry, P.G Gregoire, G.W. Babish and G.Weiss. 1997. Vegetation component report. Canadian Forces Base Suffield National Wildlife Area Wildlife Inventory. Canadian Wildlife Service, Environment Canada, Edmonton, Alberta.

Alberta Energy and Natural Resources. 1978a. Wapiti - Grande Prairie sand dunes integrated land use management plan. ENR Report No. 78. Alberta Energy and Natural Resources, Edmonton, Alberta. 4lpp. Figures.

Alberta Energy and Natural Resources. 1978b. Wapiti - Grande Prairie sand dunes integrated land use management plan. Appendices. ENR Report No. 78A. Alberta Energyand Natural Resources, Edmonton, Alberta. 39pp plus Appendices. Figures

Alberta Environmental Protection. 1993. Alberta plants and fungi - master species list and species group checklists. Pub. No: Ref 75. Edmonton, Alberta.

Alberta Environmental Protection. 1994. Natural regions and subregions of Alberta: Summary.

Alberta Sustainable Resource Development. 2003. Ecological Land Survey Site Description Manual. $2^{\text {nd }}$ Edition. Alberta Sustainable Resource Development, Resource Data Branch, Edmonton, Alberta. 112pp.

Allen, L. 2004. Alberta Natural Heritage Information Centre Preliminary Plant Community Tracking List. Alberta Community Development, Edmonton, Alberta.

Allen, L, J. H. Archibald, C. M. Cadrin, and D. M. Meidinger. 2004. Ranking Workshop: Boreal associations of western Canada. Unpublished document. Victoria, BC. (Cited in NatureServe 2004).

Allen, L. and J. D. Johnson (no date.) Potentially Trackable Small Patch Communities of the Maybelle Dunes, Richardson River Dunes and Marguerite Crag and Tail Wildland Parks. Alberta Environment, Edmonton, Alberta.

Allen, L., J. D. Johnson, and K. Vujnovic. 2002. Small Patch Communities of La Butte Creek Wildland Provincial Park. A report prepared for Parks and Protected Areas, Alberta Community Development, Edmonton, Alberta.

Allen, L., J. D. Johnson, and K. Vujnovic. 2003. Small Patch Communities of Fidler-Greywillow Wildland Provincial Park. A report prepared for Parks and Protected Areas, Alberta Community Development, Edmonton, Alberta.

Allen, L., J. D. Johnson, and K. Vujnovic. 2004. Small Patch Communities of Colin-Cornwall Lakes Wildland Provincial Park. Prepared for Parks and Protected Areas, Alberta Community Development,Edmonton, Alberta.

Anderson, L.E., H. Crum and W.R. Buck. 1990. List of mosses of North America north of Mexico. Bryologist 93(4): 448-499.

ANHIC. 2002. List of all vascular plant elements (2002-11-19). Alberta Natural Heritage Information Centre, Parks and Protected Areas Division, Alberta Community Development. 
Baldwin, K.A., D. Meidinger, K.A. Mcllwrick, J.H. Archibald, W.H. MacKenzie, M. McLaughlan, C.E. Kennedy, C. DeLong, and L. Allen. 2004. Canadian Forest Ecosystem Classification: Boreal associations and sub-associations for western Canada. Unpublished document. Natural Resources Canada, Canadian Forest Service, Great Lakes Forestry Centre, Sault Ste. Marie, Ontario. (Cited in NatureServe 2004).

Beckingham, J.D. and J.H. Archibald. 1996. Field guide to ecosites of northern Alberta. Natural Resources Canada, Canadian Forest Service, Northwest Region, Northern Forestry Centre, Edmonton, Alberta.

Braun-Blanquet, J. 1965. Plant sociology: the study of plant communities. English translation of Pflanzensoziologie revised and edited by Fuller, G.D. and H.S. Conard. Hafner Publishing Co., London, England. 439pp.

Coenen, V. 2003. Classification of Sand Dune and Sand Plain Plant Communities in the Wainwright Dunes Ecological Reserve. Prepared for Resource Data Branch, Alberta Sustainable Resource Development, Edmonton Alberta. Prepared by Geowest Environmental Consultants Ltd., Edmonton, Alberta 78pp. Appendices.

Cottonwood Consultants Ltd. 1986. The Proposed Wainwright Ecological Reserve A Biophysical Overview Alberta Recreation \& Parks, Edmonton, Alberta. 43pp.

Corns, I.G.W. 1983. Forest community types of west-central Alberta in relation to selected environmental factors. Can. J. For. Res. 13: 995-1010.

David, P. P. 1977. Sand Dune Occurrence of Canada: A Theme and Resource Inventory Study of Eolian Landforms of Canada. Contract No. 74-230. Department of Geology University of Montreal, and Indian and Northern Affairs National Parks Branch. 183pp.

Downing, D, and E. Karpuk. 1992. Aspen vegetation types of the Low Boreal Mixedwood Ecoregion. East- Central Alberta. First Approximation. Alberta Forestry, Lands and Wildlife, Resource Information Branch, Edmonton, Alberta. 76pp.

Environmental Management Associates. 1993. Deciduous forest types of the Lower Boreal Cordilleran Ecoregion, West Central Alberta. First approximation. Prepared for Resource Information Branch, Alberta Forestry, Lands and Wildlife, Edmonton. 155pp.

Esslinger, T.L. and R.S. Egan. 1995. A sixth checklist of the lichen-forming, lichenicolous and allied fungi of the continental United States and Canada. The Bryologist 98: 47-549

Flora of North America Editorial Committee (Eds.). 1993-2004. Flora of North America north of Mexico. $7+$ Vols. New York and Oxford.

Greenall, J.A. 1996. Manitoba's terrestrial plant communities. Manitoba Conservation Data Centre MS Report 96-02.

Grossman, D.H., D. Faber-Langendoen, A.S. Weakley, M. Anderson, P. Bourgeron, R. Crawford, K. Goodin, S. Landaal, K. Metzler, K.D. Patterson, M. Pyne, M. Reid, and L. Sneddon. 1998. International classification of ecological communities: terrestrial vegetation of the United States. Volume I, The National Vegetation Classification System: development, status, and applications. The Nature Conservancy: Arlington, VA. 
Hay W. and D. J. O'Leary. 1988. Integrated Resource Inventory of the Wandering River Study Area Resource Information Services Land Information Services Division Alberta Forestry, Land and Wildlife, Edmonton. 154 pp.

Hermesh, R. 1972. The Study of the Ecology of the Athabasca Sand Dunes with Emphasis on the Phytogenic Aspects of Dune Formation. University of Saskatchewan. $158 \mathrm{pp}$.

Jennings, M., O. Loucks, D. Glenn-Lewin, R. Peet, D. Faber-Langendoen, D. Grossman, A. Damman, M. Barbour, R. Pfister, M.Walker, S. Talbot, J. Walker, G. Hartshorn, G. Waggoner, M. Abrams, A. Hill, D. Roberts, D. Tart, M. Rejmanek. 2003. Guidelines for Describing Associations and Alliances of The U.S. National Vegetation Classification. The Ecological Society of America Vegetation Classification Panel Version 2.0 (March 28, 2003). Ecological Society of America, U.S. Federal Geographic Data Committee, NatureServe, and U.S. Geological Survey.

Larsen, J. A. 1990. Plant community composition: Boreal Forest and tundra. North America Data: 1958 1974. A reconnaissance base-line survey of vegetational communities, with bioclimatological implications. University of Wisconsin, Centre for Climatic Research, Madison Wisconsin, USA.

McCune, B. and M.J. Mefford. 1999. Multivariate analysis of ecological data, Version 4. MjM Software Design, Gleneden Beach, Oregon, USA.

Mackenzie River Basin Committee. 1981. Athabasca sand dunes in Saskatchewan. Prepared by the Mackenzie River Basin Committee.

Meijer, M. 2002a. Vegetation Communities of Maybelle River Wildland Provincial Park. Alberta Community Development Parks and Protected Areas, Lac La Biche, Alberta 31pp.

Meijer, M. 2002b. Vegetation Communities of Richardson River Dunes Wildland Provincial Park Alberta Community Development Parks and Protected Areas, Lac La Biche, Alberta 30pp.

Meijer, M. 2002c. Vegetation Communities of Marguerite Crag and Tail Wildland Provincial Park Alberta Community Development Parks and Protected Areas, Lac La Biche, Alberta 46pp.

Moss, E.H. 1983. Flora of Alberta. 2nd edition. (Revised by J. Packer) University of Toronto Press, Toronto Ontario. 687pp.

NatureServe. 2004. NatureServe Explorer: An online encyclopaedia of life [web application]. Version 4.1. NatureServe, Arlington, Virginia. Available http://www.natureserve.org/explorer.

Nelson, S., D. O’Leary and D. Downing. 1989. Holmes Crossing proposed Natural Area Biophysical Inventory. Resource Information Branch, Alberta Forestry, Lands, and Wildlife, Edmonton, Alberta. $135 \mathrm{pp}+$ Maps.

Raup, M. H. and G.W. Argus. 1982. The Lake Athabasca Sand Dunes of Northern Saskatchewan and Alberta, Canada. I. The Land and Vegetation. Botany Publ. No. 12. National Museum of Canada, Ottawa Ontario. 96 pp.

Sims, R. A., W. D. Towill, K. A. Baldwin, and G. M. Wickware. 1989. Field guide to the forest ecosystem classification for northwestern Ontario. Ontario Ministry of Natural Resources. (Cited in NatureServe 2004).

Stotler, R. and B. Crandall-Stotler. 1977. A checklist of the liverworts and hornworts of North America. The Bryologist 80: 151-165. 
Strong, W.L. 2002. Lodgepole pine/Labrador tea type communities of western Canada. Can. J. Bot. 80: 151-165

Strong, W.L. and K.R. Leggat. 1992. Ecoregions of Alberta. Prepared for Alberta Forestry, Lands and Wildlife, Land Information Services Division, Edmonton, Alberta. 59pp + Maps.

Thompson, W.H. and P.L. Hansen. 2002. Classification and management of riparian and wetland sites of the Alberta Grassland Natural Region and adjacent subregions. Bitterroot Restoration Inc. Prepared for the Alberta Riparian Habitat Management Program-Cows and Fish, Lethbridge, Alberta.

Timoney, K.P. and A.L. Robinson. 1998. A Floristic and Landscape Survey of the Ft. Assiniboine Sandhills Wildland Park. Alberta Environmental Protection, Edmonton, Alberta.

Vujnovic, K. and J. Bentz. 2001. Preliminary classification of native wheat grass (Agropyron spp.) community types in Alberta. Prep for. Alberta Natural Heritage Information Centre, Edmonton, Alberta. Prep by. Geowest Environmental Consultants Ltd., Edmonton, Alberta.

Wallis, C. 1990. Reconnaissance Survey of Saline Wetlands and Springs in the Grassland-Parkland Region of Eastern Alberta. World Wildlife Fund and Alberta Forestry, Lands and Wildlife. Edmonton, Alberta. (Cited in Allen 2004.)

Wheatley, M. and J. Bentz. 2002. A preliminary classification of plant communities in the Central Parkland Natural Subregion of Alberta. Prepared for Alberta Sustainable Resource Development, Resource Data Branch, Edmonton. Prepared by Geowest Environmental Consultants Ltd., Edmonton.

Wildlands Ecological Consulting Ltd. 2004. Survey and Analysis of Plant Community Types of Writingon-Stone Provincial Park. Final Report. Prepared for Alberta Sustainable Resource Development, Resource Data Branch, Edmonton, Alberta. Prepared by Wildlands Ecological Consulting Ltd., Red Deer, Alberta.

Willoughby, M., K.M. Sundquist and D. Downing. 1997. Range Plant Community Types and Carrying Capacity for the Dry and Central Mixedwood Subregions, Second approximation. Environmental Protection, Lands and Forest Services, Edmonton, Alberta. 144pp + Appendices.

Zoladeski, C.A., G.M. Wickware, R.J. Delorme, R.A. Sims, and I.G.W. Corns. 1995. Forest ecosystem classification for Manitoba: Field guide. Special Report 2. Natural Resources Canada, Canadian Forest Service, Northwest Region, Northern Forestry Centre, Edmonton, Alberta. 


\section{APPENDICES}


Appendix I. Plant species list for the Boreal Sand Dunes study.

Codes

Scientific Name

\begin{tabular}{|l|l}
\hline ABIEBAL Abies balsamea & \\
\hline
\end{tabular}

ACHIMIL Achillea millefolium

ACTARUB Actaea rubra

AGROSCA Agrostis scabra

ALNUTEN Alnus incana ssp tenuifolia

\begin{tabular}{|l|l}
\hline ALNUVIR & Alnus viridis \\
\hline
\end{tabular}

ALOPAEQ Alopecurus aequalis

AMELALN Amelanchier alnifolia

ANDRPOL Andromeda polifolia

ANDRSEP Androsace septentrionalis

ANEMMUL Anemone multifida

\begin{tabular}{|l|l}
\hline ANEMPAR & Anemone parviflora \\
\hline
\end{tabular}

APOCAND Apocynum androsaemifolium

\begin{tabular}{l|l}
\hline ARABDIV & Arabis divaricarpa \\
\hline
\end{tabular}

\begin{tabular}{l|l}
\hline ARABHOL & Arabis holboellii
\end{tabular}

ARABLYR Arabis lyrata

ARALNUD Aralia nudicaulis

\begin{tabular}{|l|l}
\hline ARCTUVA & Arctostaphylos uva-ursi \\
\hline
\end{tabular}

ARTECAM Artemisia campestris

\begin{tabular}{l|l}
\hline ASTECIL & Aster ciliolatus \\
\hline
\end{tabular}

ASTECON Aster conspicuus

\begin{tabular}{|l|l}
\hline ASTELAE & Aster laevis \\
\hline
\end{tabular}

ASTRROB Astragalus robbinsii

\begin{tabular}{|l|l}
\hline ASTRSTR & Astragalus striatus \\
\hline
\end{tabular}

AULAPAL Aulacomnium palustre

BETUPAP Betula papyrifera

BETUPUM Betula pumila

\begin{tabular}{|l|l}
\hline BOTRVIR & Botrychium virginianum \\
\hline
\end{tabular}

BRACSAL Brachythecium salebrosum

CALACAN Calamagrostis canadensis

CALASTR Calamagrostis stricta

CALALON Calamovilfa longifolia

CALTPAL Caltha palustris

CAMPROT Campanula rotundifolia

CAREAQU Carex aquatilis

CARECUR Carex canescens

CARECAN Carex canescens ssp canescens

CARECHO Carex chordorrhiza

CARECRA Carex crawfordii

CAREDEW Carex deweyana

CAREDIA Carex diandra

CAREDIS Carex disperma

CAREINT Carex interior

CARELAS Carex lasiocarpa

CARELEP Carex leptalea

CAREPAP Carex paupercula

CAREPEN Carex pensylvanica

CARESIC Carex siccata

CAREX\$\$ Carex spp.

CARETEN Carex tenuiflora

CAREUMB Carex umbellata

\begin{tabular}{ll}
\hline CAREUTR & Carex utriculata \\
\hline
\end{tabular}

CAREVAG Carex vaginata

CLADMIT Cladina mitis

CLADARB Cladina arbuscula

CLADRAN Cladina rangiferina

CLADBEL Cladonia bellidiflora

CLADCAR Cladonia cariosa

CLADCOR Cladonia cornuta

CLADDEF Cladonia deformis

CLADFUR Cladonia furcata

CLADGRA Cladonia gracilis

CLADMUL Cladonia multiformis

\begin{tabular}{|ll}
\hline CLADONIA & Cladonia spp.
\end{tabular}

ra

Common Name

SRank GRank Tracked Code

balsam fir

common yarrow

red and white baneberry

rough hair grass

river alder

green alder

short-awned foxtail

saskatoon

bog rosemary

northern fairy candelabra

cut-leaved anemone

small wood anemone

spreading dogbane

purple rock cress

reflexed rock cress

lyre-leaved rock cress

wild sarsaparilla

common bearberry

plains wormwood

Lindley's aster

showy aster

smooth aster

Robbins' milk vetch

ascending purple milk vetch

tufted moss

white birch

dwarf birch

Virginia grape fern

bluejoint

narrow reed grass

sand grass

marsh-marigold

harebell

water sedge

\section{short sedge}

prostrate sedge

Crawford's sedge

Dewey's sedge

two-stamened sedge

two-seeded sedge

inland sedge

hairy-fruited sedge

bristle-stalked sedge

sun-loving sedge

hay sedge

thin-flowered sedge

umbellate sedge

small bottle sedge

sheathed sedge

reindeer lichen

reindeer lichen

reindeer lichen

\begin{tabular}{|c|c|c|c|}
\hline S5 & G5 & N & PGPIN01020 \\
\hline
\end{tabular}

\begin{tabular}{l|l|l|l} 
S5 & G5 & $\mathrm{N}$ & PDAST03030
\end{tabular}

\begin{tabular}{l|l|l|l} 
S5 & G5 & $\mathrm{N}$ & PDRAN02020 \\
\hline
\end{tabular}

\begin{tabular}{l|l|l|l} 
S5 & G5 & $\mathrm{N}$ & PMPOA04120
\end{tabular}

\begin{tabular}{l|l|l|l} 
S5 & G5T5 & $\mathrm{N}$ & PDBET01022 \\
\hline
\end{tabular}

\begin{tabular}{l|l|l|l} 
S5 & G5 & N & PDBET01080
\end{tabular}

\begin{tabular}{l|l|l|l} 
S5 & G5 & $\mathrm{N}$ & PMPOA07010
\end{tabular}

\begin{tabular}{l|l|l|l} 
S5 & G5 & $\mathrm{N}$ & PDROS05010
\end{tabular}

\begin{tabular}{l|l|l|l} 
S5 & G5 & $\mathrm{N}$ & PDERI02010
\end{tabular}

\begin{tabular}{l|l|l|l} 
S5 & G5 & $\mathrm{N}$ & PDPRI02060
\end{tabular}

\begin{tabular}{l|l|l|l}
$\mathrm{S} 5$ & $\mathrm{G} 5$ & $\mathrm{~N}$ & PDRAN040E0 \\
\hline
\end{tabular}

\begin{tabular}{l|l|l|l} 
S5 & G5 & $\mathrm{N}$ & PDRAN040J0 \\
\hline
\end{tabular}

\begin{tabular}{l|l|l|l} 
S5 & G5 & $\mathrm{N}$ & PDAPO06010 \\
\hline
\end{tabular}

\begin{tabular}{l|l|l|l}
$\mathrm{S} 5$ & $\mathrm{G} 5$ & $\mathrm{~N}$ & PDBRA060G0
\end{tabular}

$\begin{array}{llll}\text { S5 } & \text { G5 } & \mathrm{N} & \text { PDBRA060W0 }\end{array}$

\begin{tabular}{l|l|l|l} 
S4 & G5 & $\mathrm{N}$ & PDBRA06140
\end{tabular}

\begin{tabular}{l|l|l|l} 
S5 & G5 & $\mathrm{N}$ & PDARA02040
\end{tabular}

\begin{tabular}{l|l|l|l} 
S5 & G5 & $\mathrm{N}$ & PDERI041J0
\end{tabular}

\begin{tabular}{l|l|l|l} 
S5 & G5 & $N$ & PDASTOSOD0
\end{tabular}

\begin{tabular}{l|l|l|l}
$\mathrm{S} 5$ & $\mathrm{G} 5$ & $\mathrm{~N}$ & PDASTE8480
\end{tabular}

\begin{tabular}{l|l|l|l} 
S5 & G5 & $\mathrm{N}$ & PDASTEB070
\end{tabular}

\begin{tabular}{l|l|l|l} 
S5 & G5 & $\mathrm{N}$ & PDASTE80Y0 \\
\hline
\end{tabular}

\begin{tabular}{c|c|c|c} 
S3 & G5 & $\mathrm{N}$ & PDFAB0F7P0 \\
\hline
\end{tabular}

\begin{tabular}{l|l|l|l} 
S5 & G5 & $\mathrm{N}$ & PDFAB0F061
\end{tabular}

S4

S5

S4S5 $\quad$ G5

G5

G5

S5

$\mathrm{S} 4$

S4

G5

G5

G5

S5 $\quad$ G5

S5 $\quad$ G5

S5

S?

S5

S5

S5

S4

S5

S5

S3

S4

S5

$\mathrm{S} 4$

$\mathrm{S} 4$

G5

G5

G5T5

G5

G5

G5

G5

G5

G5

G5

G5

$\mathrm{N}$

$\frac{N}{N}$

PDBET020C0

PDBET020HO

N $\mathrm{PPOPH} 010 \mathrm{HO}$

\begin{tabular}{l|l}
$\mathrm{N}$ & PMPOA17050
\end{tabular}

N PMPOA 17170

N PMPOA18050

N PDRAN06030

N PDCAM020T0

N PMCYP030V0

N $\quad$ PMCYP032F0

N $P M C Y P 032 F 4$

$\mathrm{N}$ PMCYP032U0

N PMCYP03370

N PMCYP033Q0

N PMCYP033R0

$\mathrm{N}$ PMCYP033U0

N

N PMCYP03720

N PMCYP037E0

N PMCYP03G30

N

\begin{tabular}{l|l|l|l} 
& G5 & N & PMCYP034V2 \\
\hline S3S4 & G5 & N & PMCYP03DL0 \\
\hline
\end{tabular}

\begin{tabular}{c|c|c|c} 
S1 & G5 & Y & PMCYP03E60 \\
\hline
\end{tabular}

\begin{tabular}{ll|ll} 
S5 & G5 & N & PMCYP03H90
\end{tabular}

\begin{tabular}{l|l|l|l} 
S5 & G5 & N & PMCYP03E90 \\
\hline
\end{tabular} 
Appendix I. Plant species list for the Boreal Sand Dunes study.

\begin{tabular}{|c|c|c|c|c|c|c|}
\hline Codes & Scientific Name & Common Name & SRank & GRank & Tracked & Code \\
\hline CLADUNC & Cladonia uncialis & & & & & \\
\hline CORATRI & Corallorhiza trifida & pale coralroot & S5 & G5 & $\mathrm{N}$ & PMORCOM050 \\
\hline CORNCAN & Cornus canadensis & bunchberry & S5 & G5 & $\mathrm{N}$ & PDCOR01040 \\
\hline CORNSTOL & Cornus stolonifera & red-osier dogwood & S5 & G5 & $\mathrm{N}$ & PDCOR010H0 \\
\hline CORYCOR & Corylus cornuta & beaked hazelnut & S5 & G5 & $\mathrm{N}$ & PDBET04030 \\
\hline CREPTEC & Crepis tectorum & annual hawk's -beard & SE & G? & $\mathrm{N}$ & PDAST2ROMO \\
\hline DANTSPI & Danthonia spicata & poverty oat grass & S1S2 & G5 & $\mathrm{Y}$ & PMPOA200A0 \\
\hline DICRPOL & Dicranum polysetum & wavy dicranum & & & & \\
\hline DISPTRA & Disporum trachycarpum & fairybells & S5 & G5 & $\mathrm{N}$ & PMLILOR060 \\
\hline DICRANU & Dicranum spp. & & & & & \\
\hline LYCOCOM & Diphasiastrum complanatum & ground-cedar & S5 & G5 & $\mathrm{N}$ & PPLYC01090 \\
\hline DREPADU & Drepanocladus aduncus & brown moss & & & & \\
\hline DRYOCAR & Dryopteris carthusiana & narrow spinulose shield fern & S4 & G5 & $\mathrm{N}$ & PPDRY0A040 \\
\hline ELEOPAL & Eleocharis palustris & creeping spike-rush & S5 & G5 & $\mathrm{N}$ & PMCYP091E0 \\
\hline ELYMTRA & Elymus trachycaulus & slender wheatgrass & S5 & G5 & $\mathrm{N}$ & PMPOA2H0QO \\
\hline EPILANG & Epilobium angustifolium & common fireweed & S5 & G5 & $\mathrm{N}$ & PDONA06020 \\
\hline EPILPAL & Epilobium palustre & marsh willowherb & S3 & G5 & $\mathrm{N}$ & PDONA060R0 \\
\hline EPIPHTES & Epiphyte spp. & & & & & \\
\hline EQUIARV & Equisetum arvense & common horsetail & S5 & G5 & $\mathrm{N}$ & PPEQU01010 \\
\hline EQUIFLU & Equisetum fluviatile & swamp horsetail & S5 & G5 & $\mathrm{N}$ & PPEQU01020 \\
\hline EQUIHYE & Equisetum hyemale & common scouring-rush & S5? & G5 & $\mathrm{N}$ & PPEQU01030 \\
\hline EQUILAE & Equisetum laevigatum & smooth scouring-rush & S4 & G5 & $\mathrm{N}$ & PPEQU01040 \\
\hline EQUIPRA & Equisetum pratense & meadow horsetail & S5 & G5 & $\mathrm{N}$ & PPEQU01060 \\
\hline EQUISCI & Equisetum scirpoides & dwarf scouring-rush & S5 & G5 & $\mathrm{N}$ & PPEQU01080 \\
\hline EQUISYL & Equisetum sylvaticum & woodland horsetail & S5 & G5 & $\mathrm{N}$ & PPEQU01090 \\
\hline ERIGGLA & Erigeron glabellus & smooth fleabane & S5 & G5 & $\mathrm{N}$ & PDAST3M1P0 \\
\hline ERIOVAG & Eriophorum vaginatum & sheathed cotton grass & S5 & G5 & $\mathrm{N}$ & PMCYPOAOCO \\
\hline EURHPUL & Eurhynchium pulchellum & & & & & \\
\hline EVERMES & Evernia mesomorpha & & & & & \\
\hline FESTSAX & Festuca saximontana & Rocky Mountain fescue & S5 & G5 & $\mathrm{N}$ & PMPOA2VORO \\
\hline FRAGVIR & Fragaria virginiana & wild strawberry & S5 & G5 & $\mathrm{N}$ & PDROSOR040 \\
\hline GALIBOR & Galium boreale & northern bedstraw & S5 & G5 & $\mathrm{N}$ & PDRUBONOBO \\
\hline GALILAB & Galium labradoricum & Labrador bedstraw & S3 & G5 & $\mathrm{N}$ & PDRUBON160 \\
\hline GALITRI & Galium trifidum & small bedstraw & S5 & G5 & $\mathrm{N}$ & PDRUBON260 \\
\hline GALITRF & Galium triflorum & sweet-scented bedstraw & S5 & G5 & $\mathrm{N}$ & PDRUBON270 \\
\hline GAULHIS & Gaultheria hispidula & creeping snowberry & S3 & G5 & $\mathrm{N}$ & PDERIOF010 \\
\hline GENTAMA & Gentianella amarella & felwort & S5 & G5 & $\mathrm{N}$ & PDGEN07010 \\
\hline GEOCLIV & Geocaulon lividum & northern bastard toadflax & S5 & G5 & $\mathrm{N}$ & PDSAN04010 \\
\hline GEUMMAC & Geum macrophyllum & large-leaved yellow avens & S5 & G5 & $\mathrm{N}$ & PDROS0S080 \\
\hline GEUMTRI & Geum triflorum & three-flowered avens & S5 & G5 & $\mathrm{N}$ & PDROSOSOFO \\
\hline GOODREP & Goodyera repens & lesser rattlesnake plantain & S5 & G5 & $\mathrm{N}$ & PMORC17030 \\
\hline GYMNDRY & Gymnocarpium dryopteris & oak fern & S5 & G5 & $\mathrm{N}$ & PPDRY0D030 \\
\hline HIERUMB & Hieracium umbellatum & narrow-leaved hawkweed & S5 & G5? & $\mathrm{N}$ & PDAST4W1N0 \\
\hline HIPPVUL & Hippuris vulgaris & common mare's-tail & S5 & G5 & $\mathrm{N}$ & PDHPR01030 \\
\hline HORDJUB & Hordeum jubatum & foxtail barley & S5 & G5 & $\mathrm{N}$ & PMPOA38070 \\
\hline HUDSTOM & Hudsonia tomentosa & sand heather & S3 & G5 & $\mathrm{N}$ & PDCIS03030 \\
\hline HYLOSPL & Hylocomium splendens & stair-step moss & & & & \\
\hline HYPNGYM & Hypogymnia spp. & 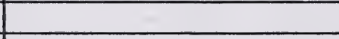 & & & & \\
\hline ICMAERI & Icmadophila ericetorum & & & & & \\
\hline IMPANOL & Impatiens noli-tangere & western jewelweed & S3 & G? & $\mathrm{N}$ & PDBAL01070 \\
\hline JUNCBAL & Juncus balticus & wire rush & S5 & G5 & $\mathrm{N}$ & PMJUN010A0 \\
\hline JUNCNOD & Juncus nevadensis & Nevada rush & S1 & G5 & $\mathrm{Y}$ & PMJUN011Z0 \\
\hline JUNCDUD & Juncus tenuis & slender rush & S5 & G5 & $N$ & PMJUN012S0 \\
\hline KOELMAC & Koeleria macrantha & June grass & S5 & G5 & $\mathrm{N}$ & PMPOA3G040 \\
\hline LARILAR & Larix laricina & tamarack & S5 & G5 & $\mathrm{N}$ & PGPIN02020 \\
\hline LATHOCH & Lathyrus ochroleucus & cream-colored vetchling & S5 & G4G5 & $N$ & PDFAB250M0 \\
\hline LEDUGRO & Ledum groenlandicum & common Labrador tea & S5 & G5 & $\mathrm{N}$ & PDERIOM020 \\
\hline ELYMINN & Leymus innovatus & hairy wild rye & S5 & G5 & $\mathrm{N}$ & PMPOA6P090 \\
\hline LILIPHI & Lilium philadelphicum & western wood lily & S5 & G5 & $\mathrm{N}$ & PMLIL1AOLO \\
\hline LINNBOR & Linnaea borealis & twinflower & S5 & G5 & $\mathrm{N}$ & PDCPR02010 \\
\hline LONIDIO & Lonicera dioica & twining honeysuckle & S5 & G5 & $\mathrm{N}$ & PDCPR03080 \\
\hline LONIINV & Lonicera involucrata & bracted honeysuckle & S5 & G4G5 & $\mathrm{N}$ & PDCPR030F0 \\
\hline LYCOANN & Lycopodium annotinum & stiff club-moss & S5 & G5 & $N$ & PPLYC01030 \\
\hline LYCODEN & Lycopodium dendroideum & ground-pine & S? & G5 & $\mathrm{N}$ & PPLYC010B0 \\
\hline
\end{tabular}


Appendix I. Plant species list for the Boreal Sand Dunes study.

Codes

LYCOANN

LYCOCLA

MAIACAN

MELALIN

MENYTRI

MERTPAN

MITENUD

MNIUMS

MONEUNI

MOSS\$\$ $\$$

MUHLGLO

ORTHSEC

ORYZPUN

OXYCMIC

PARNPAL

PELTAPH

PELTCAN

PELTMAL

PELTIGE

PETAPAL

PETASAG

PHALARU

PICEGLA

PICEMAR

PINUBAN

HABEHYP

PLEUSCH

POAINTE

POAPALU

POAPRAT

POHLNUT

POLYAMP

POLYLAP

POLYCOM

POLYPIL

POLYTRI

POLYSTR

POPUBAL

POPUTRE

POTENOR

POTEPAL

PRUNPEN

PRUNVIR

PTILCRI

PYLAPOL

PYROASA

PYROCHL

RANUSCE

RIBEGLA

RIBEOXY

RIBETRI

RORIPAL

ROSAACI

RUBUACA

RUBUIDA

RUBUPUB

RUMEMAR

SALIBEB

SALICAN

SALIDIS

SALILUT

SALIMAC

SALIMYR

SALIPED
Scientific Name

Lycopodium annotinum

Lycopodium clavatum

Maianthemum canadense

Medicago lupulina

Menyanthes trifoliata

Mertensia paniculata

Mitella nuda

Mnium sp.

Moneses uniflora

Moss spp.

Muhlenbergia glomerata

Orthilia secunda

Oryzopsis pungens

Oxycoccus microcarpus

Parnassia panviflora

Peltigera aphthosa

Peltigera canina

Peltigera malacea

Peltigera spp.

Petasites frigidus var palmatus

Petasites frigidus var sagittatus

Phalaris arundinacea

Picea glauca

Picea mariana

Pinus banksiana

Platanthera hyperborea

Pleurozium schreberi

Poa interior

Poa palustris

Poa pratensis

Pohlia nutans

Polygonum amphibium

Polygonum lapathifolium

Polytrichum commune

Polytrichum piliferum

Polytrichum spp.

Polytrichum strictum

Populus balsamifera

Populus tremuloides

Potentilla norvegica

Potentilla palustris

Prunus pensylvanica

Prunus virginiana

Ptilium crista-castrensis

Pylaisiella polyantha

Pyrola asarifolia

Pyrola chlorantha

Ranunculus sceleratus

Ribes glandulosum

Ribes oxyacanthoides

Ribes triste

Rorippa palustris

Rosa acicularis

Rubus arcticus

Rubus idaeus

Rubus pubescens

Rumex maritimus

Salix bebbiana

Salix candida

Salix discolor

Salix lutea

Salix maccalliana

Salix myrtillifolia

Salix pedicellaris
Common Name

SRank GRank Tracked Code

stiff club-moss

running club-moss

wild lily-of-the-valley

black medick

buck-bean

tall lungwort

bishop's-cap

one-flowered wintergreen

bog muhly

one-sided wintergreen

northern rice grass

small bog cranberry

small northern grass-of-parnassus

\begin{tabular}{l|l|l|l|}
\hline S5 & G5 & $\mathrm{N}$ & PPLYC01030 \\
\hline
\end{tabular}

\begin{tabular}{l|l|l|l} 
S3 & G5 & N & PPLYC01080
\end{tabular}

\begin{tabular}{l|l|l|l} 
S5 & G5 & $\mathrm{N}$ & PMLIL1D010
\end{tabular}

\begin{tabular}{l|l|l|l}
$\mathrm{SE}$ & $\mathrm{G} ?$ & $\mathrm{~N}$ & PDFAB2G050
\end{tabular}

\begin{tabular}{l|l|l|l} 
S5 & G5 & $\mathrm{N}$ & PDMNY02010
\end{tabular}

\begin{tabular}{l|l|l|l}
$\mathrm{S} 5$ & $\mathrm{G} 5$ & $\mathrm{~N}$ & PDBORONOH0
\end{tabular}

\begin{tabular}{l|l|l|l} 
S5 & G5 & N & PDSAX0N050
\end{tabular}

S5

G5

$\mathrm{N}$

PDPYR02010

$\mathrm{S} 4$

S5

S4

S5

S2

G5

G5

G5

G5

G4

$+$

palmate-leaved coltsfoot

arrow-leaved coltsfoot

reed canary grass

white spruce

black spruce

jack pine

northern green bog orchid

Schreber's moss

inland bluegrass

fowl bluegrass

Kentucky bluegrass

copper wire moss

water smartweed

pale persicaria

common hair-cap

awned hair-cap

hair-cap spp.

slender hair-cap

balsam poplar

aspen

rough cinquefoil

marsh cinquefoil

pin cherry

choke cherry

knight's plume moss

common pink wintergreen

greenish-flowered wintergreen

celery-leaved buttercup

skunk currant

northern gooseberry

wild red currant

marsh yellow cress

prickly rose

dwarf raspberry

wild red raspberry

dewberry

golden dock

beaked willow

hoary willow

pussy willow

yellow willow

velvet-fruited willow

myrtle-leaved willow

bog willow

S5

S5

S5

S5

S5

S5

55

$\mathrm{S} 5$

S5

S5

S5

S5

S5

S5

S5

$\mathrm{S} 5$

S5

G5T5

G5

G5

G5

G5

G5

G5

G5

G5

G5

N

PMPOA480U0

N PDPYR03010

N PMPOA80020

N PDERIIV010

$\mathrm{Y}$

PDSAXOPOAO

S5

S5

S5

S5

S5

S5

S5

S5

S5

S5

S5

S5

S5

$\mathrm{S} 4$

S5

S5

S5

S5

S4

G5

G5

G5

G5

G5

G5

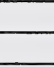

G5

G5

G5

G5

G5

G5

G5

G5

G5

G5

G5

G5

G5

G5

G4G5

G5? 
Appendix I. Plant species list for the Boreal Sand Dunes study.

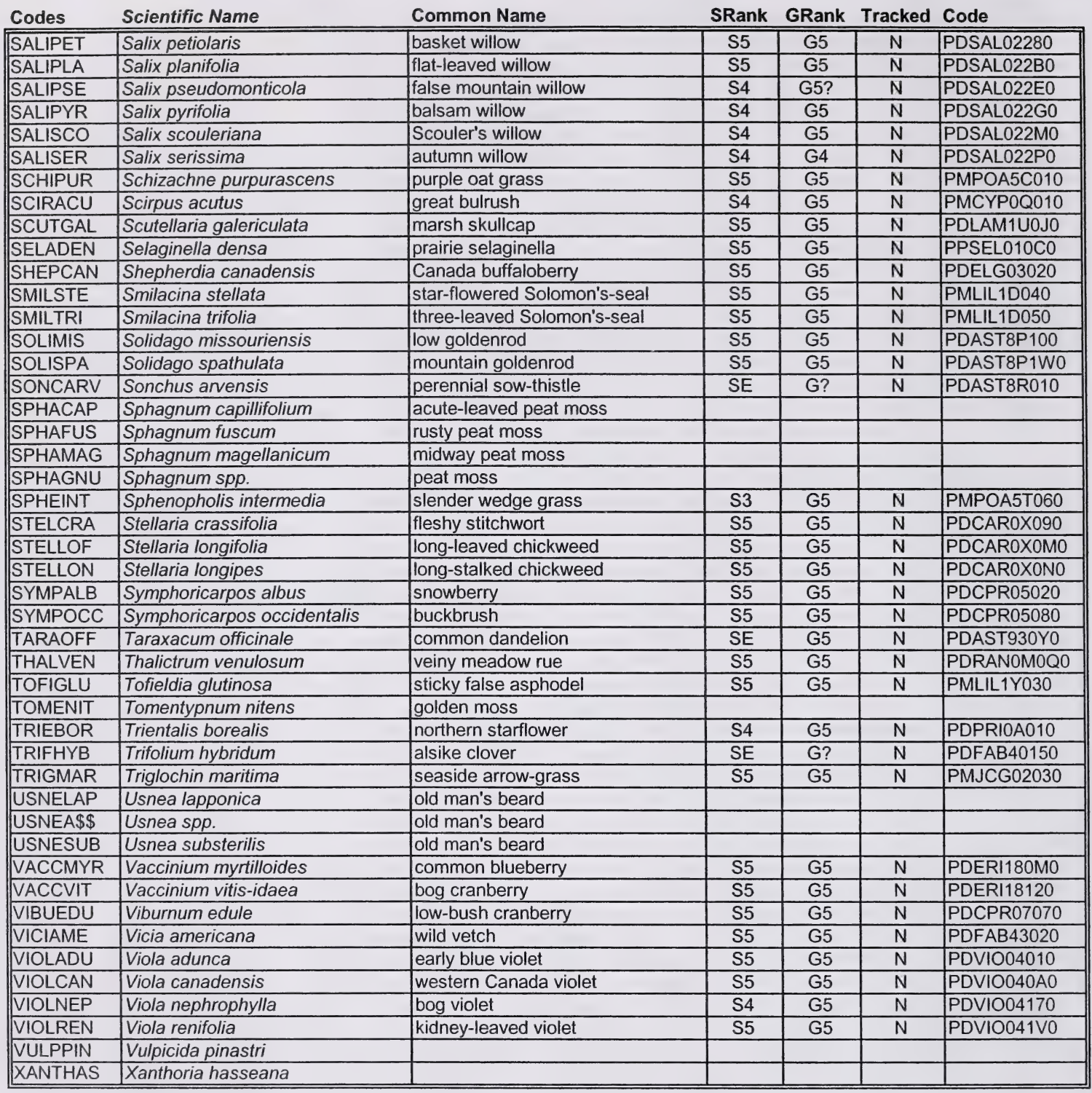


Appendix II. Results of Detrended Correspondence Analysis of plot data using PC-ORD (Version 4.25).

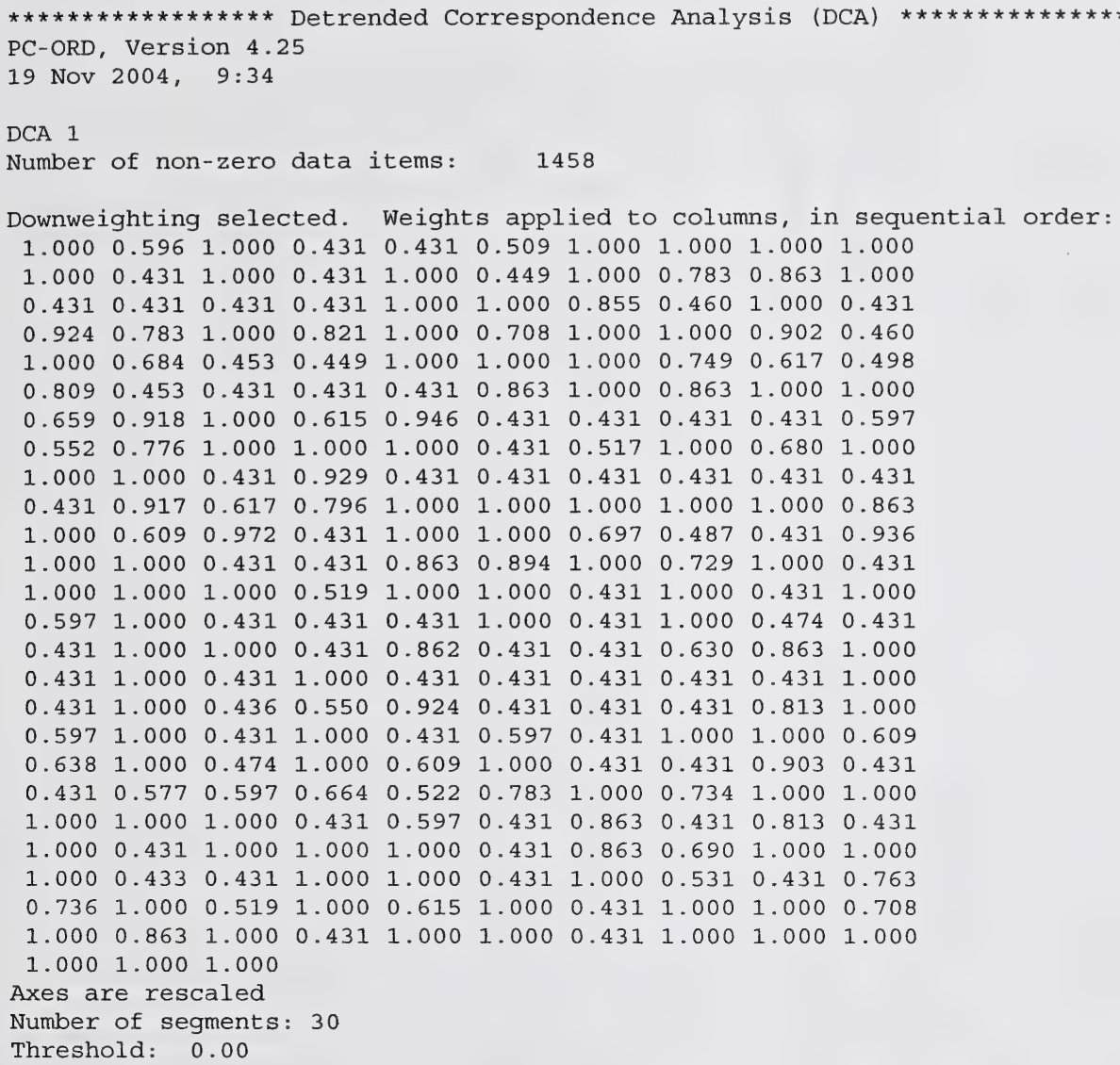




\begin{tabular}{|c|c|c|c|c|}
\hline & = residual & at & & \\
\hline 0.0000004727 & $=$ residual & at & iteration & 23 \\
\hline 0.1190475598 & $=$ residual & at & iteration & 24 \\
\hline 0.0063445764 & $=$ residual & at & iteration & 25 \\
\hline 0.0445261970 & $=$ residual & at & iteration & 26 \\
\hline 0.0096673742 & $=$ residual & at & iteration & 27 \\
\hline 0.0056653209 & residual & at & iteration & 28 \\
\hline 0.0036140494 & residual & at & iteration & 29 \\
\hline 0.0022466285 & residual & at & iteration & 30 \\
\hline 0.0014912705 & residual & at & iteration & 31 \\
\hline 0.0009280191 & residual & at & iteration & 32 \\
\hline 0.0006163297 & $=$ residual & at & iteration & \\
\hline 0.0003837069 & $=$ residual & at & iteration & 34 \\
\hline 0.0002549287 & residual & at & iteration & 35 \\
\hline 0.0001588938 & residual & at & iteration & 36 \\
\hline 0.0001055532 & residual & at & iteration & 37 \\
\hline 0.0000657907 & residual & at & iteration & 38 \\
\hline 0.0000437332 & residual & at & iteration & 39 \\
\hline 0.0000273482 & $=$ residual & at & iteration & 40 \\
\hline 0.0000181394 & $=$ residual & at & & 41 \\
\hline 0.0000112172 & residual & at & iter & 42 \\
\hline 0.0000075563 & residual & at & itera & 43 \\
\hline 0.0000046820 & $=$ residual & at & iterat & 44 \\
\hline 0.0000031206 & $=$ residual & at & on & 45 \\
\hline 0.0000019936 & idual & at & itera & 46 \\
\hline 0.0000016032 & idual & at & itera & 47 \\
\hline 0.0000011653 & $=$ residual & at & iteration & 48 \\
\hline 0.2303885669 & dual & at & Lon & 49 \\
\hline 0.0115810595 & residual & at & iter & 50 \\
\hline 0.0003506005 & residual & at & iter & 60 \\
\hline 0.0000036946 & dual & at & & 70 \\
\hline 0.0026632999 & $=$ res & at & iter & 80 \\
\hline 0.0000345992 & $=$ residual & at & itera & 90 \\
\hline 0.0000005082 & = residual & at & itera & 100 \\
\hline 0.0007267480 & $=$ res & at & on & 110 \\
\hline 0.0000096942 & idual & at & iter & 120 \\
\hline 0.0032333490 & $=$ residual & at & itera & 130 \\
\hline 0.0000472429 & $=$ residual & at & iter & 140 \\
\hline 0.0000005483 & idual & at & on & 150 \\
\hline 0.0022208698 & sidual & at & on & 160 \\
\hline 0.0000228227 & $=$ residual & at & itera & 170 \\
\hline 0.0000468319 & $=$ residual & at & iter & 180 \\
\hline 0.0000628998 & sidual & at & & 190 \\
\hline 0.0001568405 & $=$ residual & at & iter & 200 \\
\hline 0.0000007513 & $=$ residual & at & iterat & 210 \\
\hline 0.0049229800 & $=$ residual & at & itera & 220 \\
\hline 0.0000653137 & idual & at & & 230 \\
\hline 0.0000006551 & $=$ residual & at & iter & 240 \\
\hline 0.0005921249 & $=$ residual & at & iteration & 250 \\
\hline 0.0000077118 & residual & at & iter & 260 \\
\hline 0.0198870935 & $=$ residual & at & & 270 \\
\hline 0.0012696030 & $=$ residual & at & iteration & 280 \\
\hline 0.0000082241 & $=$ residual & at & iteration & 290 \\
\hline 0.0000003215 & $=$ residual & at & ion & 300 \\
\hline 0.0006083100 & $=$ residual & at & iterat & 310 \\
\hline 0.0000054650 & $=$ residual & at & iteration & 320 \\
\hline 0.0159484260 & $=$ residual & at & iteration & 330 \\
\hline 0.0001836747 & $=$ residual & at & iteration & 340 \\
\hline 0.0000018164 & $=$ residual & at & iteration & 350 \\
\hline 0.0009468747 & $=$ residual & at & iteration & 360 \\
\hline 0.0000125468 & $=$ residual & at & iteration & 370 \\
\hline 0.0253839884 & $=$ residual & at & iteration & 380 \\
\hline 0.0010038624 & = residual & at & & \\
\hline
\end{tabular}


Appendix II. Results of Detrended Correspondence Analysis of plot data using PC-ORD (Version 4.25).

$0.0000147146=$ residual at iteration 400

0.0165320933 = residual at iteration 410

$0.0007467355=$ residual at iteration 420

$0.0000054340=$ residual at iteration 430

0.0274292659 = residual at iteration 440

$0.0004935919=$ residual at iteration 450

$0.0000065075=$ residual at iteration 460

$0.0073069599=$ residual at iteration 470

0.0000988046 = residual at iteration 480

$0.0000022887=$ residual at iteration 490

0.0019169722 = residual at iteration 500

0.0000288135 = residual at iteration 510

$0.0000101585=$ residual at iteration 520

$0.1484064460=$ residual at iteration 530

0.0015916921 = residual at iteration 540

0.0000116232 = residual at iteration 550

$0.0007812140=$ residual at iteration 560

0.0000117117 = residual at iteration 570

$0.0418574996=$ residual at iteration 580

$0.0001863229=$ residual at iteration 590

0.0000028643 = residual at iteration 600

$0.0004720774=$ residual at iteration 610

$0.0000073205=$ residual at iteration 620

$0.0000662483=$ residual at iteration 630

$0.0051104380=$ residual at iteration 640

$0.0000780318=$ residual at iteration 650

$0.0000013967=$ residual at iteration 660

0.0071194670 = residual at iteration 670

$0.0000881599=$ residual at iteration 680

$0.0000009063=$ residual at iteration 690

$0.0120708309=$ residual at iteration 700

0.0001696577 = residual at iteration 710

$0.0000024202=$ residual at iteration 720

$0.0024696013=$ residual at iteration 730

0.0000343769 = residual at iteration 740

0.0000002521 = residual at iteration 750

0.0094927615 = residual at iteration 760

$0.0001403433=$ residual at iteration 770

0.0000022236 residual at iteration 780

$0.0015595420=$ residual at iteration 790

0.0000162045 = residual at iteration 800

0.0096977735 = residual at iteration 810

$0.0004224988=$ residual at iteration 820

$0.0000047016=$ residual at iteration 830

$0.0172148515=$ residual at iteration 840

$0.0002469053=$ residual at iteration 850

$0.0000027543=$ residual at iteration 860

$0.0056762183=$ residual at iteration 870

$0.0000650966=$ residual at iteration 880

$0.0348629616=$ residual at iteration 890

$0.0004047484=$ residual at iteration 900

$0.0000047449=$ residual at iteration 910

0.0122945467 = residual at iteration 920

0.0001578231 = residual at iteration 930

0.0000020552 = residual at iteration 940

$0.0002424767=$ residual at iteration 950

0.0000037015 = residual at iteration 960

0.0228236541 = residual at iteration 970

0.0001794746 = residual at iteration 980

0.0000008551 = residual at iteration 990

$0.0013641322=$ residual at iteration 999

$0.8945347071=$ eigenvalue

** BEWARE *** RESIDUAL BIGGER THAN TOLERANCE, WHICH IS 0.0000001000 
Appendix II. Results of Detrended Correspondence Analysis of plot data using PC-ORD (Version 4.25).

Length of gradient: Length of segments: Length of segments: Length of segments: Length of segments: Length of gradient:

$\begin{array}{lllll}7.959 & & & \\ 0.40 & 0.39 & 0.38 & 0.36 & 0.34 \\ 0.18 & 0.16 & 0.15 & 0.14 & 0.15 \\ 0.17 & 0.15 & 0.14 & 0.15 & 0.16 \\ 0.23 & 0.23 & 0.21 & 0.11 & 0.08 \\ 9.844 & & & \end{array}$

0.31

0.16

$0.17-0.19$

$0.08-0.08$ 9. 844

Length of gradient: Length of segments: Length of segments: Length of segments: Length of segments: Length of segments: Length of gradient:

$$
10.556
$$

$0.26 \quad 0.25$

$0.25 \quad 0.23$

$0.22 \quad 0.22$

0.310 .29

$0.28 \quad 0.26$

10.490

\section{$\begin{array}{lll}0.25 & 0.24 & 0.24\end{array}$}

$\begin{array}{llll}0.21 & 0.20 & 0.21\end{array}$

$\begin{array}{llll}0.22 & 0.21 & 0.20\end{array}$

$\begin{array}{llll}0.24 & 0.19 & 0.18\end{array}$

$\begin{array}{lll}0.20 & 0.17 & 0.16\end{array}$
0.27

0.20

0.20

0.08

0.24

0.22

0.21

$0.08-0.08$

$0.2398089916=$ residual at iteration $0.0207121540=$ residual at iteration 0.0089239823 = residual at iteration 2 0.0075835153 = residual at iteration 3 0.0042048716 = residual at iteration 4 0.0035145332 = residual at iteration 5 0.0019377953 = residual at iteration 6 $0.0016169508=$ residual at iteration 7 0.0008946412 = residual at iteration 8 0.0007493552 = residual at iteration 9 0.0004162877 = residual at iteration 10 0.0003499313 = residual at iteration 11 $0.0001948600=$ residual at iteration 12 $0.0001642199=$ residual at iteration 13 $0.0000915615=$ residual at iteration 14 $0.0000771620=$ residual at iteration 15 $0.0000429797=$ residual at iteration 16 0.0000363351 = residual at iteration 17 0.0000201823 = residual at iteration 18 0.0000170653 = residual at iteration 19 $0.0000094463=$ residual at iteration 20 0.0000080322 = residual at iteration 21 $0.0000044156=$ residual at iteration 22 $0.0000037889=$ residual at iteration 23 $0.0000020658=$ residual at iteration 24 $0.0000018036=$ residual at iteration 25 0.0000009059 = residual at iteration 26 0.0041822996 = residual at iteration 27 $0.0010179664=$ residual at iteration 28 0.0006773428 = residual at iteration 29 $0.0001915030=$ residual at iteration 30 $0.0001757940=$ residual at iteration 31 $0.0000596469=$ residual at iteration 32 0.0000586263 = residual at iteration 33 $0.0000193281=$ residual at iteration 34 $0.0000202655=$ residual at iteration 35 $0.0000054017=$ residual at iteration 36 $0.0000085276=$ residual at iteration 37 $0.0000003473=$ residual at iteration 38 $0.0641232654=$ residual at iteration 39 $0.0096786162=$ residual at iteration 40 $0.0130840838=$ residual at iteration 41 0.0215954762 = residual at iteration 42 0.0162168294 = residual at iteration 43 $0.0154263927=$ residual at iteration 44 $0.0095649473=$ residual at iteration 45 
Appendix II. Results of Detrended Correspondence Analysis of plot data using PC-ORD (Version 4.25).

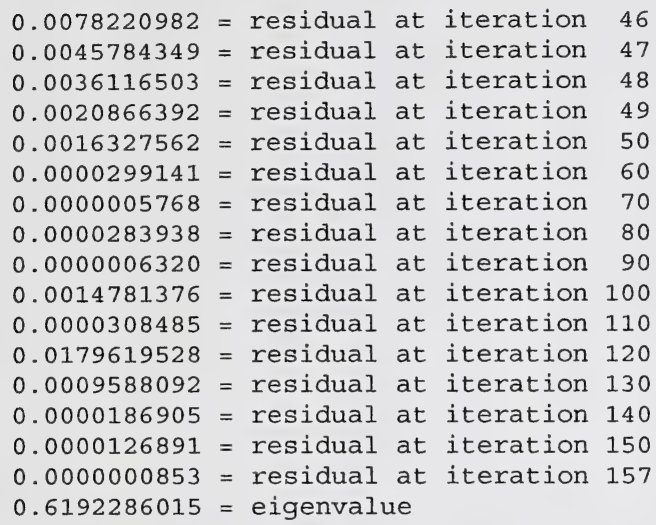

Length of gradient: Length of segments: Length of segments: Length of segments: Length of gradient:

$$
\begin{aligned}
& 4.082 \\
& \begin{array}{llllllllll}
0.28 & 0.28 & 0.29 & 0.30 & 0.30 & 0.29 & 0.27 & 0.25 & 0.22 & 0.20 \\
0.19 & 0.16 & 0.15 & 0.15 & 0.15 & 0.14 & 0.11 & 0.09 & 0.09 & 0.09
\end{array} \\
& 0.09 \\
& 4.944 \\
& 5.095
\end{aligned}
$$

Length of gradient Length of segments: Length of segments: Length of segments: Length of gradient:

$\begin{array}{llllllllll}0.22 & 0.20 & 0.19 & 0.18 & 0.18 & 0.18 & 0.19 & 0.19 & 0.20 & 0.21 \\ 0.22 & 0.23 & 0.23 & 0.23 & 0.22 & 0.22 & 0.23 & 0.24 & 0.25 & 0.23 \\ 0.17 & 0.14 & 0.13 & 0.13 & 0.14 & 0.14 & & & & \\ 5.028 & & & & & & & & \end{array}$

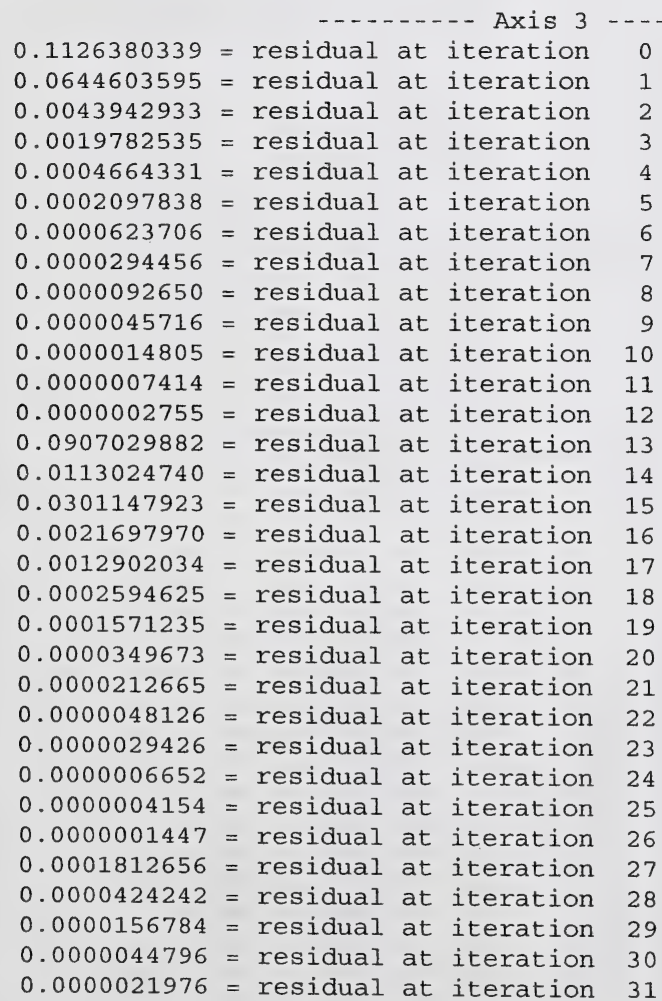


$0.0000007014=$ residual at iteration 32

0.0000004137 = residual at iteration 33

$0.0000002385=$ residual at iteration 34

0.1101496369 = residual at iteration 35

0.0152153959 = residual at iteration 36

0.0109550394 = residual at iteration 37

0.0008371857 = residual at iteration 38

0.0003251712 = residual at iteration 39

$0.0001215950=$ residual at iteration 40

$0.0000492965=$ residual at iteration 41

$0.0000191847=$ residual at iteration 42

$0.0000080499=$ residual at iteration 43

$0.0000032080=$ residual at iteration 44

$0.0000013583=$ residual at iteration 45

0.0000005617 = residual at iteration 46

$0.0000004457=$ residual at iteration 47

$0.0000005199=$ residual at iteration 48

0.0000001071 = residual at iteration 49

$0.1448341608=$ residual at iteration 50

$0.0000006754=$ residual at iteration 60

0.0000048462 = residual at iteration 70

$0.0000294132=$ residual at iteration 80

0.0023212289 = residual at iteration 90

$0.0000001148=$ residual at iteration 100

$0.0000025999=$ residual at iteration 110

0.0000137237 = residual at iteration 120

0.0019042946 = residual at iteration 130

0.0954642594 = residual at iteration 140

0.0000006332 = residual at iteration 150

$0.0000913391=$ residual at iteration 160

0.0292956177 = residual at iteration 170

0.0679236948 = residual at iteration 180

$0.0000024715=$ residual at iteration 190

$0.0000000744=$ residual at iteration 194

0.4693661332 = eigenvalue

Length of gradient: Length of segments: Length of segments: Length of segments: Length of gradient:

Length of gradient: Length of segments: Length of segments: Length of segments: Length of gradient:

$$
\begin{array}{rl}
\multicolumn{1}{c}{4.574} \\
0.15 & 0.15 \\
0.36 & 0.37 \\
0.10 & 0.10 \\
4.784 \\
\multicolumn{1}{c}{4.589} \\
0.19 & 0.18 \\
0.22 & 0.23 \\
0.19 & 0.18 \\
4.442
\end{array}
$$

$\begin{array}{lll}0.15 & 0.14 & 0.14 \\ 0.34 & 0.29 & 0.24\end{array}$

0.15

0.17

0.22

0.27

0.32

0.10

0.21

0.18

0.17

0.15

0.11

DCA 1

SPECIES SCORES

$\begin{array}{rcrrr}\text { N } & \text { NAME } & \text { AX1 } & \text { AX2 } & \text { AX3 } \\ 1 & \text { 2BETUPAP } & 365 & 73 & 249 \\ 2 & \text { 2PICEGLA } & 204 & 333 & 196 \\ 3 & \text { 2PICEMAR } & 565 & 42 & 321 \\ 4 & \text { 2PINUBAN } & 343 & 12 & 222 \\ 5 & \text { 2POPUBAL } & 529 & 38 & 228 \\ 6 & \text { 2POPUTRE } & 216 & 144 & 276 \\ 7 & \text { 1BETUPAP } & 301 & 531 & 139 \\ 8 & \text { 1LARILAR } & 588 & 105 & 251 \\ 9 & \text { 1PICEGLA } & 453 & 82 & 186 \\ 10 & \text { 1PICEMAR } & 419 & 79 & 244 \\ 11 & \text { 1PINUBAN } & 267 & 22 & 358\end{array}$

$\begin{array}{llllllll}0.16 & 0.16 & 0.17 & 0.19 & 0.20 & 0.21 & 0.21 & 0.22 \\ 0.24 & 0.25 & 0.24 & 0.22 & 0.20 & 0.18 & 0.18 & 0.19\end{array}$

0.17

.250 .24

0.22

0.20

0.18

.18 
Appendix II. Results of Detrended Correspondence Analysis of plot data using PC-ORD (Version 4.25).

\begin{tabular}{|c|c|c|c|c|}
\hline 12 & 1POPUBAL & 212 & 441 & 57 \\
\hline 3 & 1POPUTRE & 214 & 367 & 104 \\
\hline 4 & 3ABIEBAL & 529 & 38 & 228 \\
\hline 5 & 3AMELALN & 108 & 219 & 412 \\
\hline & 3ANDRPOL & 623 & 228 & 170 \\
\hline & 3ARCTUVA & 118 & 203 & 412 \\
\hline 0 & 3BETUPAP & 1063 & 144 & 229 \\
\hline & 3BETUPUM & 840 & 286 & 135 \\
\hline & 3CORNCAN & 247 & 277 & 145 \\
\hline & 3 CORYCOR & 207 & 339 & 164 \\
\hline & 3CORNSTO & 213 & 441 & 57 \\
\hline & 3GAULHIS & 428 & 67 & 310 \\
\hline & 3LAR I LAR & 621 & 229 & 169 \\
\hline 3 & 3 LEDUGRO & 480 & 494 & 175 \\
\hline & 3LINNBOR & 295 & 241 & 110 \\
\hline & 3LONIINV & 224 & 413 & 73 \\
\hline 0 & 3OXYCMIC & 470 & 511 & 194 \\
\hline 9 & 3PICEGLA & 346 & 52 & 186 \\
\hline & 3PICEMAR & 456 & 512 & 195 \\
\hline & 3PINUBAN & 316 & 4 & 240 \\
\hline 32 & 3 POPUBAL & 1075 & 172 & 218 \\
\hline & 3POPUTRE & 182 & 169 & 128 \\
\hline & 3 PRUNPEN & 103 & 475 & 445 \\
\hline 3 & 3PRUNVIR & 85 & 281 & 422 \\
\hline 30 & 3RIBETRI & 409 & 159 & 244 \\
\hline & 3RUBUIDA & 237 & 336 & 112 \\
\hline 8 & 3ROSAACI & 204 & 249 & 228 \\
\hline 3 & 3SALIBEB & 836 & 224 & 182 \\
\hline 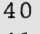 & 3SALIMYR & 616 & 350 & 93 \\
\hline & 3SALI PED & 866 & 213 & 190 \\
\hline 1 & 3SALIPET & 894 & 212 & 203 \\
\hline 3 & 3SALIPLA & 1041 & 210 & 218 \\
\hline & 3SALIPSE & 1091 & 207 & 217 \\
\hline \pm & 3SYMPOCC & 81 & 375 & 355 \\
\hline 5 & 3VACCMYR & 267 & 286 & 138 \\
\hline 4 & 3VACCVIT & 332 & 208 & 267 \\
\hline & 3VIBUEDU & 216 & 414 & 68 \\
\hline 4 & 4AMELALN & 150 & 384 & 81 \\
\hline 5 & 4BETUPAP & 321 & 303 & 105 \\
\hline 5 & 4BETUPUM & 716 & 222 & 183 \\
\hline 5 & 4 CORNSTO & 214 & 440 & 57 \\
\hline 53 & $4 \mathrm{CORYCOR}$ & 189 & 440 & 76 \\
\hline 54 & 4 LAR I LAR & 621 & 229 & 169 \\
\hline 55 & 4 LONI INV & 213 & 441 & 57 \\
\hline 56 & 3LONIDIO & 176 & 423 & 68 \\
\hline 57 & 4ROSAACI & 220 & 362 & 81 \\
\hline 58 & 4RUBUIDA & 216 & 323 & 112 \\
\hline 59 & 4 PICEGLA & 303 & 137 & 178 \\
\hline 60 & 4 POPUTRE & 140 & 246 & 316 \\
\hline 61 & 4PICEMAR & 437 & 509 & 198 \\
\hline 62 & 4 PRUNVIR & 167 & 336 & 107 \\
\hline 63 & 4 PRUNPEN & 171 & 354 & 121 \\
\hline 64 & 4SALIBEB & 333 & 310 & 85 \\
\hline 65 & 4SALICAN & 844 & 219 & 191 \\
\hline 66 & 4SALIPLA & 1042 & 218 & 176 \\
\hline 67 & 4SALIPYR & 798 & 229 & 210 \\
\hline 68 & 4SALI PED & 1042 & 210 & 218 \\
\hline 69 & 4SALIPET & 1042 & 218 & 176 \\
\hline 70 & 4SHEPCAN & 253 & 101 & 365 \\
\hline 71 & 4VIBUEDU & 192 & 440 & 72 \\
\hline 72 & 5ALNUTEN & 397 & 248 & 126 \\
\hline 73 & 5ALNUVIR & 202 & 213 & 302 \\
\hline 74 & 5AMELALN & 176 & 239 & 261 \\
\hline
\end{tabular}

229 HPOLYLAP 1092 237 HRUMEMAR 1092

244 HSONCARV 1092

127 GALOPAEQ 1092

163 GPOAPALU 1091

44 3SALIPSE 1091

131 GCAREAQU 1080

205 HGALITRI 1080

32 3POPUBAL 1075

18 3BETUPAP 1063

231 HPOTENOR 1049

66 4SALIPLA 1042

68 4SALIPED 1042

69 4SALIPET 1042

87 5SALIPET 1042

208 HGEUMMAC 1042

43 3SALIPLA 1041

189 HCREPTEC 1020

159 GMUHLGLO 1007

187 HCICUMAC 1007

130 GCALASTR 984

193 HEPILPAL 972

136 GCAREDIA 933

132 GCARECHO 924

148 GCAREUTR 912

42 3SALIPET 894

41 3SALIPED 866

65 4SALICAN 844

19 3BETUPUM 840

230 HPOLYAMP 839

39 3SALIBEB 836

135 GCARECUR 817

141 GCARELAS 817

92 MAULAPAL 816

67 4SALIPYR 798

238 HSCUTGAL 787

95 MDREPADU 777

232 HPOTEPAL 759

51 4BETUPUM 716

228 HPETASAG 697

128 GCALACAN 684

107 MSPHAMAG 672

185 HCALTPAL 666

86 4SALIMYR 640

88 5SALIPLA 640

90 5SALISER 640

77 5LARILAR 632

195 HEQUIFLU 628

110 MTOMENIT 625

16 3ANDRPOL 623

139 GCAREINT 621

168 GTRIGMAR 621

188 HCORATRI

24 3LARILAR

204 HGALILAB

210 HHABEHYP

54 4LARILAR

222 HMENYTRI

247 HTOFIGLU

144 GCAREPAP

147 GCAREVAG

40 3SALIMYR

79 5PICEMAR
217 HLYCOANN 506

235 HRUBUACA 503

102 MPOHLNUT 497

25 3LEDUGRO 494

34 3PRUNPEN 475

82 5PRUNPEN 465

183 HASTRROB 459

145 GCAREPEN 441

22 3CORNSTO 441

91 5VIBUEDU 441

12 1POPUBAL 441

206 HGALITRF 441

55 4LONIINV 441

71 4VIBUEDU 440

190 HDISPTRA 440

52 4CORNSTO 440

53 4CORYCOR 440

56 3LONIDIO 423

224 HMERTPAN 418

48 3VIBUEDU 414

27 3LONIINV 413

171 HANDRSEP 407

170 HACTARUB 403

156 GJUNCBAL 402

246 HTHALVEN 399

125 GELYMTRA 395

248 HTRIEBOR 389

49 4AMELALN 384

84 5SALIBEB 381

97 MMOSSES\$ 379

45 3SYMPOCC 375

13 1POPUTRE 367

144 GCAREPAP 365

147 GCAREVAG 365

198 HEQUIPRA 364

184 HASTRSTR 363

57 4ROSAACI 362

63 4PRUNPEN 354

142 GCAREUMB 351

182 HASTELAE 351

40 3SALIMYR 350

249 HVICIAME 350

233 HPYROASA 345

239 HSELADEN 344

149 GCAREX\$\$ 343

242 HSOLIMIS 343

192 HEPILANG 342

209 HGEOCLIV 342

21 3CORYCOR 339

76 5BETUOCC 337

37 3RUBUIDA 336

78 5PICEGLA 336

62 4PRUNVIR 336

243 HSOLISPA 335

2 2PICEGLA 333

106 MPYLAPOL 333

180 HASTECON 332

115 LCLADDEF 331

178 HARALNUD 327

58 4RUBUIDA 323

203 HGALIBOR 318

152 GELYMINN 314

64 4SALIBEB 310 
Appendix II. Results of Detrended Correspondence Analysis of plot data using PC-ORD (Version 4.25).

\begin{tabular}{|c|c|c|c|c|}
\hline 75 & & 304 & & \\
\hline 76 & & 372 & 337 & 62 \\
\hline 77 & 5LAR I LAR & 632 & 227 & 172 \\
\hline 78 & 5PICEGLA & 289 & 336 & 110 \\
\hline & 5PICEMAR & 608 & 269 & 123 \\
\hline 80 & 5PINUBAN & 390 & 16 & 242 \\
\hline & 5POPUTRE & 245 & 514 & 141 \\
\hline & 5PRUNPEN & 197 & 465 & 176 \\
\hline & 5PRUNVIR & 209 & 74 & 399 \\
\hline 84 & 5SALIBEB & 235 & 381 & 96 \\
\hline 85 & 5SALIMAC & 428 & 67 & 310 \\
\hline & 4SALIMYR & 640 & 129 & 419 \\
\hline & 5SALIPET & 1042 & 210 & 218 \\
\hline 88 & 5SALIPLA & 640 & 129 & 419 \\
\hline 89 & 5SALIPSE & 293 & 546 & 156 \\
\hline 90 & 5SALISER & 640 & 129 & 419 \\
\hline 91 & 5VIBUEDU & 213 & 441 & 57 \\
\hline 92 & MAULAPAL & 816 & 188 & 194 \\
\hline 93 & MBRACSAL & 443 & 86 & 171 \\
\hline 94 & MDICRPOL & 337 & 17 & 332 \\
\hline 95 & MDREPADU & 77 & 176 & 261 \\
\hline & MHYLOSPL & & 31 & 175 \\
\hline & MMOSSES\$ & 60 & 379 & 56 \\
\hline 0 & MMOSS\$\$1 & 381 & 279 & 125 \\
\hline & MMOSS\$\$2 & 81 & 279 & 125 \\
\hline 0 & MMOSS\$\$3 & 29 & 289 & 180 \\
\hline & MPLEUSCH & 356 & 28 & 315 \\
\hline 2 & MPOHLNUT & 415 & 497 & 210 \\
\hline 3 & MPOLYPIL & -7 & 111 & -54 \\
\hline & MPOLYTRI & 70 & 304 & 405 \\
\hline & MPTILCRI & 354 & 66 & 262 \\
\hline 6 & MPYLAPOL & 27 & 333 & 143 \\
\hline & MSPHAMAG & 672 & 148 & 17 \\
\hline 8 & MSPHAFUS & 471 & 510 & 96 \\
\hline 9 & MSPHAGNU & 56 & 512 & 195 \\
\hline 0 & MTOMENIT & 525 & 292 & 124 \\
\hline & LCLADONI & 17 & 133 & -30 \\
\hline 12 & LCLADBEL & 161 & 198 & 4. \\
\hline 13 & LCLADCAR & 82 & -124 & 260 \\
\hline 4 & LCLADCOR & 82 & -124 & 260 \\
\hline & LCLADDEF & 53 & 331 & 266 \\
\hline 16 & LCLADGRA & 04 & 22 & 136 \\
\hline 7 & LCLADMIT & 43 & -19 & 88 \\
\hline & LCLAD & 10 & 215 & 406 \\
\hline & LCLADUNC & -18 & 106 & 1 \\
\hline & LICMAERI & 428 & 67 & 31 \\
\hline & LPELTIGE & 88 & 166 & 4 \\
\hline & LPELTAPH & 37 & 126 & 18 \\
\hline & LPELTCAN & 151 & 74 & 37 \\
\hline & LPELTMAL & -7 & 124 & 8 \\
\hline & GELYMTRA & -23 & 395 & 49 \\
\hline & GAGROSCA & 560 & 38 & 1 \\
\hline & GALOPAEQ & 1092 & 207 & 21 \\
\hline & GCALACAN & 684 & 215 & 25 \\
\hline & GCALALON & 78 & 226 & 40 \\
\hline & GCALASTR & 984 & 213 & 20 \\
\hline & GCAREAQU & 1080 & 191 & 28 \\
\hline & GCARECHO & 924 & 236 & 12 \\
\hline & GCARECAN & 428 & 67 & 31 \\
\hline 34 & GCARECRA & 1092 & 207 & 21 \\
\hline & GCARECUR & 817 & 205 & 21 \\
\hline & GCAREDIA & 933 & 216 & 20 \\
\hline & GCAREDEW & 209 & 74 & 39 \\
\hline
\end{tabular}

97 MMOSSES\$

138 GCAREDIS

8 ILARILAR

140 GCARELEP

3 2PICEMAR

126 GAGROSCA

122 LPELTAPH

240 HSMILTRI

5 2POPUBAI

100 MMOSS\$\$3

14 3ABIEBAL

252 EEPIPHYT

235 HRUBUACA

194 HEQUIARV

121 LPELTIGE

25 3LEDUGRO

108 MSPHAFUS

28 3OXYCMIC

220 HMITENUD

153 GERIOVAG

109 MSPHAGNU

30 3PICEMAR

9 1PICEGLA

253 EUSNEA\$\$

93 MBRACSAL

61 4PICEMAR

133 GCARECAN

146 GCARETEN

85 5SALIMAC

173 HANEMPAR

23 3GAULHIS

120 LICMAERI

96 MHYLOSPL

10 1PICEMAR

102 MPOHLNUT

36 3RIBETRI

225 HORTHSEC

72 5ALNUTEN

80 5PINUBAN

98 MMOSS\$\$1

99 MMOSS\$\$2

76 5BETUOCC

227 HPETAPAL

1 2BETUPAP

250 HVIOLREN

202 HFRAGVIR

236 HRUBUPUB

199 HEQUISCI

101 MPLEUSCH

105 MPTILCRI

217 HLYCOANN

115 LCLADDEF

209 HGEOCLIV

29 3PICEGLA

4 2PINUBAN

94 MDICRPOL

64 4SALIBEB

47 3VACCVIT

248 HTRIEBOR

191 HDRYOCAR

50 4BETUPAP

162 GPOAINTE

31 3PINUBAN
600 596 588 579 565 560 537 532 529 529 529 519 491 490 488 480 471 470 466 456 456 456

453 452 443 437 428 428 428 428 428 428 427 419 415 409 405 397 390 381 381 372 368 365 362 359 357 356 356 354 353 353 346 346 343 337 333 332 327 321 321

317 316
202 HFRAGVIR 310 196 HEQUIHYE 309 216 HLYCODEN 309 214 HLATHOCH 306 165 GSCHIPUR 304 104 MPOLYTRI 304 50 4BETUPAP 303 110 MTOMENIT 292 169 HACHIMIL 291 100 MMOSS\$\$3 289 19 3BETUPUM 286 46 3VACCMYR 286 181 HASTECIL 285 35 3PRUNVIR 281 98 MMOSS\$\$1 279 99 MMOSS\$\$2 279 20 3CORNCAN 277 79 SPICEMAR 269 215 HLILIPHI 255 234 HPYROCHL 251 38 3ROSAACI 249 251 HVIOLADU 249 72 5ALNUTEN 248 225 HORTHSEC 246 60 4POPUTRE 246 26 3LINNBOR 241 231 HPOTENOR 241 138 GCAREDIS 239 74 5AMELALN 239 132 GCARECHO 236 230 HPOLYAMP 236 139 GCAREINT 235 172 HANEMMUL 232

67 4SALIPYR 229

168 GTRIGMAR 229

188 HCORATRI 229

24 3LARILAR 229

204 HGALILAB 229

210 HHABEHYP 229

54 4LARILAR 229

222 HMENYTRI 229

247 HTOFIGLU 229

16 3ANDRPOL 228

77 SLARILAR 227

195 HEQUIFLU 227

129 GCALALON 226

160 GORYZPUN 226

39 3SALIBEB 224

197 HEQUILAE 224

236 HRUBUPUB 224

51 4BETUPUM 222

143 GCARESIC 220

65 4SALICAN 219

15 3AMELALN 219

66 4SALIPLA 218

69 4SALIPET 218

232 HPOTEPAL 217

136 GCAREDIA 216

128 GCALACAN 215

118 LCLADRAN 215

159 GMUHLGLO 214

187 HCICUMAC 214

193 HEPILPAL 214 
Appendix II. Results of Detrended Correspondence Analysis of plot data using PC-ORD (Version 4.25).

\begin{tabular}{|c|c|c|c|c|}
\hline & & & 239 & \\
\hline & GCAREINT & & 235 & \\
\hline & GCARELEP & 579 & 13 & 66 \\
\hline & GCARELAS & 817 & 205 & 12 \\
\hline & GCAREUMB & 2 & 51 & 65 \\
\hline & GCARESIC & 18 & 220 & 268 \\
\hline & GCAREPAP & 619 & 365 & 91 \\
\hline & GCAREPEN & -25 & 441 & 502 \\
\hline & GCARETEN & 428 & 67 & 310 \\
\hline & GCAREVAG & 619 & 365 & 91 \\
\hline & GCAREUTR & 912 & 158 & $44 \varepsilon$ \\
\hline & GCAREX\$\$ & 47 & 343 & 440 \\
\hline & GDANTSPI & -7 & 115 & 62 \\
\hline & GELEOPAL & 1092 & 207 & 217 \\
\hline & GELYMINN & 253 & 314 & 94 \\
\hline & GERIOVAG & 456 & 512 & 195 \\
\hline & GFESTSAX & 13 & 159 & 35 \\
\hline & GHORDJUB & 1092 & 207 & 21 \\
\hline & GJUNCBAL & 163 & 402 & 63 \\
\hline & NCDUD & 1092 & 207 & 217 \\
\hline & GJUNCNOD & 1092 & 207 & 217 \\
\hline 9 & GMUHLGLO & 1007 & 214 & 183 \\
\hline 0 & GORYZPUN & 103 & 226 & 365 \\
\hline & ALARU & 1092 & 207 & 217 \\
\hline 2 & GPOAINTE & 317 & 75 & 2 \\
\hline 3 & GPOAPALU & 1091 & 207 & 21 \\
\hline 4 & APRAT & 12 & 186 & 4 \\
\hline 5 & GSCHIPUR & 174 & 304 & 9 \\
\hline 6 & GSCIRACU & 1092 & 207 & 21 \\
\hline 57 & HEINT & 1092 & 207 & 21 \\
\hline 8 & GTRIGMAR & 621 & 229 & 165 \\
\hline 9 & HACHIMIL & 211 & 291 & 175 \\
\hline 0 & HACTARUB & 199 & 403 & 8 \\
\hline & DRSEP & 6 & 407 & 473 \\
\hline & EMMUL & 85 & 232 & 48 \\
\hline 3 & EMPAR & 428 & 67 & 31 \\
\hline & DCAND & 150 & 167 & 43 \\
\hline & $\mathrm{BHOL}$ & 128 & 146 & 322 \\
\hline & ABDIV & 136 & 12 & \\
\hline 7 & HARABLYR & -14 & 168 & \\
\hline & ALNUD & 219 & 327 & 33 \\
\hline & TECAM & 15 & & \\
\hline & HASTECON & 276 & 32 & 80 \\
\hline 1 & HASTECIL & 171 & 85 & 148 \\
\hline 32 & HASTELAE & 32 & & 46 \\
\hline & HASTRROB & -67 & 59 & 53 \\
\hline 4 & HASTRSTR & 40 & 363 & 26 \\
\hline 35 & HCALTPAL & 666 & .75 & 28 \\
\hline & HCAMPROT & 252 & 88 & 17 \\
\hline 37 & HCICUMAC & 1007 & 14 & 83 \\
\hline 8 & HCORATRI & 621 & 29 & 65 \\
\hline & HCREPTEC & 1020 & 95 & 10 \\
\hline 90 & HDISPTRA & 190 & 440 & 7 \\
\hline 1 & HDRYOCAR & 321 & -28 & 34 \\
\hline 92 & HEPILANG & 248 & 342 & 8 \\
\hline 93 & HEPILPAL & 972 & 214 & 18 \\
\hline 94 & HEQUIARV & 490 & 84 & 16 \\
\hline 95 & HEQUIFLU & 628 & 227 & 18 \\
\hline 96 & HEQUIHYE & 10 & 309 & 51 \\
\hline 97 & HEQUILAE & 38 & 224 & 9 \\
\hline 98 & HEQUI PRA & 247 & 364 & I \\
\hline & HEQUISCI & 356 & 134 & 19 \\
\hline & HEQUISYL & 285 & 532 & 13 \\
\hline
\end{tabular}

\begin{tabular}{|c|c|c|c|c|c|}
\hline 75 & 5BETUPAP & 304 & 130 & GCALASTR & 213 \\
\hline 59 & 4PICEGLA & 303 & 73 & 5ALNUVIR & 213 \\
\hline 7 & 1BETUPAP & 301 & 41 & 3SALIPED & 213 \\
\hline 26 & 3LINNBOR & 295 & 42 & 3SALIPET & 212 \\
\hline 89 & 5SALIPSE & 293 & 208 & HGEUMMAC & 210 \\
\hline 78 & 5PICEGLA & 289 & 68 & 4SALIPED & 210 \\
\hline & HEQUISYL & 285 & 43 & 3SALIPLA & 210 \\
\hline 211 & HHIERUMB & 285 & 87 & 5SALIPET & 210 \\
\hline 221 & HMELALIN & 284 & 47 & 3VACCVIT & 208 \\
\hline 180 & HASTECON & 276 & 134 & GCARECRA & 207 \\
\hline 11 & 1 PINUBAN & 267 & 237 & HRUMEMAR & 207 \\
\hline 46 & 3VACCMYR & 267 & 151 & GELEOPAL & 207 \\
\hline 70 & 4SHEPCAN & 253 & 155 & GHORDJUB & 207 \\
\hline 52 & GELYMINN & 253 & 157 & GJUNCDUD & 207 \\
\hline 186 & HCAMPROT & 252 & 158 & GJUNCNOD & 207 \\
\hline 192 & HEPILANG & 248 & 161 & GPHALARU & 207 \\
\hline 234 & HPYROCHL & 248 & 163 & GPOAPALU & 207 \\
\hline 198 & HEQUIPRA & 247 & 166 & GSCIRACU & 207 \\
\hline 219 & HMAIACAN & 247 & 167 & GSPHEINT & 207 \\
\hline 20 & 3CORNCAN & 247 & 44 & 3SALIPSE & 207 \\
\hline 81 & 5POPUTRE & 245 & 212 & HHI PPVUL & 207 \\
\hline 37 & 3RUBUIDA & 237 & 226 & HPARNPAL & 207 \\
\hline 84 & 5SALIBEB & 235 & 229 & HPOLYLAP & 207 \\
\hline 106 & MPYLAPOL & 227 & 244 & HSONCARV & 207 \\
\hline 27 & 3LONI INV & 224 & 223 & HMENTARV & 207 \\
\hline 249 & HVICIAME & 223 & 127 & GALOPAEQ & 207 \\
\hline 224 & HMERTPAN & 222 & 141 & GCARELAS & 205 \\
\hline 57 & 4ROSAACI & 220 & 135 & GCARECUR & 205 \\
\hline 178 & HARALNUD & 219 & 17 & 3ARCTUVA & 203 \\
\hline 48 & 3VIBUEDU & 216 & 207 & HGENTAMA & 203 \\
\hline 6 & 2POPUTRE & 216 & 112 & LCLADBEL & 198 \\
\hline 58 & 4 RUBUIDA & 216 & 189 & HCREPTEC & 195 \\
\hline 13 & 1POPUTRE & 214 & 241 & HSMILSTE & 194 \\
\hline 52 & 4CORNSTO & 214 & 131 & GCAREAQU & 191 \\
\hline 22 & 3CORNSTO & 213 & 205 & HGALITRI & 191 \\
\hline 91 & 5VIBUEDU & 213 & 228 & HPETASAG & 191 \\
\hline 206 & HGALITRF & 213 & 92 & MAULAPAL & 188 \\
\hline 55 & 4LONI INV & 213 & 186 & HCAMPROT & 188 \\
\hline 12 & 1POPUBAL & 212 & 164 & GPOAPRAT & 186 \\
\hline 169 & HACHIMIL & 211 & 201 & HERIGGLA & 186 \\
\hline 137 & GCAREDEW & 209 & 218 & HLYCOCOM & 180 \\
\hline 83 & 5PRUNVIR & 209 & 95 & MDREPADU & 176 \\
\hline 21 & 3CORYCOR & 207 & 185 & HCALTPAL & 175 \\
\hline 218 & HLYCOCOM & 207 & 32 & 3POPUBAL & 172 \\
\hline 38 & 3ROSAACI & 204 & 33 & 3POPUTRE & 169 \\
\hline 2 & 2PICEGLA & 204 & 177 & HARABLYR & 168 \\
\hline 73 & 5ALNUVIR & 202 & 174 & HAPOCAND & 167 \\
\hline 170 & HACTARUB & 199 & 121 & LPELTIGE & 166 \\
\hline 82 & 5PRUNPEN & 197 & 245 & HSTELLON & 166 \\
\hline 216 & HLYCODEN & 193 & 36 & 3RIBETRI & 159 \\
\hline 233 & HPYROASA & 193 & 154 & GFESTSAX & 159 \\
\hline 71 & 4VIBUEDU & 192 & 148 & GCAREUTR & 158 \\
\hline 190 & HDISPTRA & 190 & 227 & HPETAPAL & 156 \\
\hline 53 & 4CORYCOR & 189 & 107 & MSPHAMAG & 148 \\
\hline 33 & 3POPUTRE & 182 & 250 & HVIOLREN & 147 \\
\hline 113 & LCLADCAR & 182 & 175 & HARABHOL & 146 \\
\hline 114 & LCLADCOR & 182 & 18 & 3BETUPAP & 144 \\
\hline 74 & 5AMELALN & 176 & 6 & 2POPUTRE & 144 \\
\hline 56 & 3LONIDIO & 176 & 219 & HMAIACAN & 142 \\
\hline 241 & HSMILSTE & 174 & 126 & GAGROSCA & 138 \\
\hline 165 & GSCHIPUR & 174 & 59 & 4P I CEGLA & 137 \\
\hline 63 & 4 PRUNPEN & 171 & 238 & HSCUTGAL & 136 \\
\hline & HASTECIL & 171 & 199 & HEQUISCI & 13 \\
\hline
\end{tabular}


Appendix II. Results of Detrended Correspondence Analysis of plot data using PC-ORD (Version 4.25).

\begin{tabular}{|c|c|c|c|c|c|c|c|c|c|c|}
\hline 201 & HERIGGLA & 111 & 186 & 413 & 62 & 4 PRUNVIR & 167 & 111 & LCLADONI & 133 \\
\hline 202 & HFRAGVIR & 359 & 310 & 322 & 156 & GJUNCBAL & 163 & 179 & HARTECAM & 131 \\
\hline 203 & HGALIBOR & 95 & 318 & 463 & 112 & LCLADBEL & 161 & 96 & MHYLOSPL & 131 \\
\hline 204 & HGALI LAB & 621 & 229 & 169 & 213 & HHUDSTOM & 157 & 90 & 5SALISER & 129 \\
\hline 205 & HGALITRI & 1080 & 191 & 288 & 123 & LPELTCAN & 151 & 88 & 5SALI PLA & 129 \\
\hline 206 & HGALITRF & 213 & 441 & 57 & 174 & HAPOCAND & 150 & 86 & 4SALIMYR & 129 \\
\hline 207 & HGENTAMA & 145 & 203 & 225 & 49 & 4 AMELALN & 150 & 122 & LPELTAPH & 126 \\
\hline 208 & HGEUMMAC & 1042 & 210 & 218 & 214 & HLATHOCH & 148 & 124 & LPELTMAL & 124 \\
\hline 209 & HGEOCLIV & 346 & 342 & 105 & 207 & HGENTAMA & 145 & 150 & GDANTSPI & 115 \\
\hline 210 & HHABEHYP & 621 & 229 & 169 & 117 & LCLADMIT & 143 & 176 & HARABDIV & 112 \\
\hline 211 & HHIERUMB & 285 & 34 & 379 & 60 & 4 POPUTRE & 140 & 103 & MPOLYPIL & 111 \\
\hline 212 & HHI PPVUL & 1092 & 207 & 217 & 246 & HTHALVEN & 139 & 119 & LCLADUNC & 106 \\
\hline 213 & HHUDSTOM & 157 & -106 & 89 & 176 & HARABDIV & 136 & 8 & 1LARILAR & 105 \\
\hline 214 & HLATHOCH & 148 & 306 & 343 & 215 & HLILIPHI & 134 & 70 & 4SHEPCAN & 101 \\
\hline 215 & HLILIPHI & 134 & 255 & 418 & 175 & HARABHOL & 128 & 240 & HSMILTRI & 97 \\
\hline 216 & HLYCODEN & 193 & 309 & 168 & 17 & 3ARCTUVA & 118 & 220 & HMITENUD & 92 \\
\hline 217 & HLYCOANN & 353 & 506 & 160 & 251 & HVIOLADU & 116 & 93 & MBRACSAL & 86 \\
\hline 218 & HLYCOCOM & 207 & 180 & 236 & 201 & HERIGGLA & 111 & 194 & HEQUIARV & 84 \\
\hline 219 & HMAIACAN & 247 & 142 & 280 & 118 & LCLADRAN & 110 & 9 & 1PICEGLA & 82 \\
\hline 220 & HMITENUD & 466 & 92 & 190 & 15 & 3AMELALN & 108 & 252 & EEPIPHYT & 81 \\
\hline 221 & HMELALIN & 284 & 75 & 228 & 116 & LCLADGRA & 104 & 10 & 1PICEMAR & 79 \\
\hline 222 & HMENYTRI & 621 & 229 & 169 & 160 & GORYZPUN & 103 & 253 & EUSNEA\$\$ & 78 \\
\hline 223 & HMENTARV & 1092 & 207 & 217 & 34 & 3PRUNPEN & 103 & 221 & HMELALIN & 75 \\
\hline 224 & HMERTPAN & 222 & 418 & 67 & 203 & HGALIBOR & 95 & 162 & GPOAINTE & 75 \\
\hline 225 & HORTHSEC & 405 & 246 & 156 & 172 & HANEMMUL & 85 & 123 & LPELTCAN & 74 \\
\hline 226 & HPARNPAL & 1092 & 207 & 217 & 35 & 3PRUNVIR & 85 & 83 & 5PRUNVIR & 74 \\
\hline 227 & HPETAPAL & 368 & 156 & 127 & 45 & 3SYMPOCC & 81 & 137 & GCAREDEW & 74 \\
\hline 228 & HPETASAG & 697 & 191 & 266 & 129 & GCALALON & 78 & 1 & 2BETUPAP & 73 \\
\hline 229 & HPOLYLAP & 1092 & 207 & 217 & 104 & MPOLYTRI & 70 & 120 & LICMAERI & 67 \\
\hline 230 & HPOLYAMP & 839 & 236 & 153 & 242 & HSOLIMIS & 48 & 23 & 3GAULHIS & 67 \\
\hline 231 & HPOTENOR & 1049 & 241 & 101 & 149 & GCAREX\$\$ & 47 & 133 & GCARECAN & 67 \\
\hline 232 & HPOTEPAL & 759 & 217 & 199 & 184 & HASTRSTR & 40 & 146 & GCARETEN & 67 \\
\hline 233 & HPYROASA & 193 & 345 & 157 & 197 & HEQUILAE & 38 & 85 & 5SALIMAC & 67 \\
\hline 234 & HPYROCHL & 248 & 251 & 173 & 243 & HSOLISPA & 36 & 173 & HANEMPAR & 67 \\
\hline 235 & HRUBUACA & 491 & 503 & 192 & 182 & HASTELAE & 32 & 105 & MPTILCRI & 66 \\
\hline 236 & HRUBUPUB & 357 & 224 & 110 & 143 & GCARESIC & 18 & 29 & 3PICEGLA & 52 \\
\hline 237 & HRUMEMAR & 1092 & 207 & 217 & 111 & LCLADONI & 17 & 3 & 2PICEMAR & 42 \\
\hline 238 & HSCUTGAL & 787 & 136 & 207 & 179 & HARTECAM & 15 & 5 & 2POPUBAL & 38 \\
\hline 239 & HSELADEN & -28 & 344 & 488 & 154 & GFESTSAX & 13 & 14 & 3ABIEBAL & 38 \\
\hline 240 & HSMILTRI & 532 & 97 & 213 & 164 & GPOAPRAT & 12 & 211 & HHIERUMB & 34 \\
\hline 241 & HSMILSTE & 174 & 194 & 401 & 196 & HEQUIHYE & 10 & 101 & MPLEUSCH & 28 \\
\hline 242 & HSOLIMIS & 48 & 343 & 421 & 171 & HANDRSEP & 6 & 116 & LCLADGRA & 22 \\
\hline 243 & HSOLISPA & 36 & 335 & 445 & 142 & GCAREUMB & 2 & 11 & 1PINUBAN & 22 \\
\hline 244 & HSONCARV & 1092 & 207 & 217 & 245 & HSTELLON & -6 & 94 & MDICRPOL & 17 \\
\hline 245 & HSTELLON & -6 & 166 & 102 & 150 & GDANTSPI & -7 & 80 & 5PINUBAN & 16 \\
\hline 246 & HTHALVEN & 139 & 399 & 161 & 103 & MPOLYPIL & -7 & 140 & GCARELEP & 13 \\
\hline 247 & HTOFIGLU & 621 & 229 & 169 & 124 & LPELTMAL & -7 & 4 & 2 PINUBAN & 12 \\
\hline 248 & HTRIEBOR & 327 & 389 & 72 & 177 & HARABLYR & -14 & 31 & 3PINUBAN & 4 \\
\hline 249 & HVICIAME & 223 & 350 & 104 & 119 & LCLADUNC & -18 & 117 & LCLADMIT & -19 \\
\hline 250 & HVIOLREN & 362 & 147 & 186 & 125 & GELYMTRA & -23 & 191 & HDRYOCAR & -28 \\
\hline 251 & HVIOLADU & 116 & 249 & 418 & 145 & GCAREPEN & -25 & 213 & HHUDSTOM & -106 \\
\hline 252 & EEPIPHYT & 519 & 81 & 380 & 239 & HSELADEN & -28 & 113 & LCLADCAR & -124 \\
\hline 253 & EUSNEA\$\$ & 452. & 78 & 346 & 183 & HASTRROB & -67 & 114 & LCLADCOR & -124 \\
\hline
\end{tabular}

DCA 1

SAMPLE SCORES - WHICH ARE WEIGHTED MEAN SPECIES SCORES

$\begin{array}{rrrrr}N & \text { NAME } & \text { AX1 } & \text { AX2 } & \text { AX3 } \\ & & & & \\ 1 & \text { P01 } & 235 & 149 & 294 \\ 2 & \text { P02 } & 123 & 228 & 379 \\ 3 & \text { P03 } & 233 & 300 & 158 \\ 4 & \text { P04 } & 87 & 256 & 414\end{array}$

RANKED 1

$E I G=0.895$

33 P33

31 P31

13 P13

$24 \quad$ P2 4

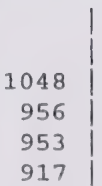

RANKED 2

$\mathrm{EIG}=0.619$

$46 \quad \mathrm{P} 46$

51 P51

58 P58

52 P52
502

490

451

368 
Appendix II. Results of Detrended Correspondence Analysis of plot data using PC-ORD (Version 4.25).

\begin{tabular}{|c|c|c|c|c|c|c|c|c|c|c|}
\hline 5 & P05 & 336 & 206 & 237 & 16 & P16 & 913 & 9 & P09 & 353 \\
\hline 6 & P06 & 210 & 29 & 185 & 12 & P12 & 893 & 54 & P54 & 352 \\
\hline 7 & P07 & 411 & 76 & 276 & 32 & P32 & 835 & 11 & P11 & 349 \\
\hline 8 & P08 & 318 & 114 & 284 & 48 & P4 8 & 728 & 34 & P34 & 331 \\
\hline 9 & P09 & 210 & 353 & 115 & 61 & P61 & 704 & 23 & P23 & 326 \\
\hline 10 & P10 & 83 & 254 & 380 & 25 & P25 & 685 & 50 & P50 & 319 \\
\hline 11 & P11 & 0 & 349 & 444 & 59 & P59 & 637 & 17 & P17 & 315 \\
\hline 12 & P12 & 893 & 239 & 160 & 15 & P15 & 605 & 3 & $\mathrm{P} 03$ & 300 \\
\hline 13 & P13 & 953 & 217 & 192 & 30 & P30 & 604 & 64 & P64 & 288 \\
\hline 14 & P14 & 92 & 254 & 382 & 35 & P35 & 560 & 22 & P 22 & 284 \\
\hline 15 & P15 & 605 & 215 & 206 & 37 & P37 & 494 & 60 & P60 & 266 \\
\hline 16 & P16 & 913 & 215 & 201 & 58 & P58 & 449 & 55 & P55 & 265 \\
\hline 17 & P17 & 235 & 315 & 156 & 36 & P36 & 422 & 30 & P30 & 262 \\
\hline 18 & P18 & 242 & 196 & 263 & 19 & P19 & 418 & 4 & P0 4 & 256 \\
\hline 19 & P19 & 418 & 111 & 205 & 7 & P07 & 411 & 20 & P20 & 256 \\
\hline 20 & P20 & 87 & 256 & 387 & 43 & P43 & 349 & 10 & P10 & 254 \\
\hline 21 & P21 & 169 & 174 & 325 & 29 & P29 & 338 & 14 & P14 & 254 \\
\hline 22 & P22 & 213 & 284 & 211 & 5 & P05 & 336 & 38 & P38 & 247 \\
\hline 23 & P23 & 217 & 326 & 147 & 55 & P55 & 329 & 12 & P12 & 239 \\
\hline 24 & P2 4 & 917 & 183 & 342 & 8 & P08 & 318 & 2 & P02 & 228 \\
\hline 25 & P25 & 685 & 211 & 258 & 26 & P26 & 306 & 13 & P13 & 217 \\
\hline 26 & P26 & 306 & 121 & 367 & 51 & P51 & 301 & 61 & P61 & 217 \\
\hline 27 & P2 7 & 128 & 195 & 396 & 46 & P4 6 & 300 & 16 & P16 & 215 \\
\hline 28 & P28 & 189 & 161 & 385 & 64 & P64 & 270 & 15 & P15 & 215 \\
\hline 29 & P29 & 338 & 41 & 323 & 41 & P41 & 270 & 32 & P32 & 213 \\
\hline 30 & P30 & 604 & 262 & 148 & 34 & P34 & 252 & 31 & P31 & 213 \\
\hline 31 & P31 & 956 & 213 & 208 & 40 & P40 & 245 & 25 & P25 & 211 \\
\hline 32 & P32 & 835 & 213 & 198 & 18 & P18 & 242 & 48 & P4 8 & 207 \\
\hline 33 & P33 & 1048 & 204 & 202 & 54 & P54 & 239 & 5 & P05 & 206 \\
\hline 34 & P34 & 252 & 331 & 116 & 50 & P50 & 236 & 33 & P33 & 204 \\
\hline 35 & P35 & 560 & 86 & 278 & 1 & P01 & 235 & 18 & P18 & 196 \\
\hline 36 & P36 & 422 & 82 & 297 & 17 & P17 & 235 & 27 & P27 & 195 \\
\hline 37 & P37 & 494 & 96 & 223 & 3 & $\mathrm{P} 03$ & 233 & 57 & P57 & 185 \\
\hline 38 & P38 & 66 & 247 & 342 & 23 & P23 & 217 & 24 & P24 & 183 \\
\hline 39 & P39 & 41 & 174 & 150 & 52 & P52 & 216 & 39 & P39 & 174 \\
\hline 40 & P40 & 245 & 15 & 218 & 22 & P22 & 213 & 21 & P21 & 174 \\
\hline 41 & P41 & 270 & 117 & 330 & 9 & P09 & 210 & 28 & P28 & 161 \\
\hline 42 & P42 & 195 & 0 & 195 & 6 & P06 & 210 & 53 & P53 & 158 \\
\hline 43 & P43 & 349 & 86 & 285 & 60 & P60 & 206 & 59 & P59 & 157 \\
\hline 44 & P4 4 & 119 & 19 & 92 & 42 & P4 2 & 195 & 49 & P49 & 154 \\
\hline 45 & P4 5 & 45 & 127 & 48 & 28 & P2 8 & 189 & 1 & P01 & 149 \\
\hline 46 & P46 & 300 & 502 & 145 & 21 & P21 & 169 & 45 & P45 & 127 \\
\hline 47 & P47 & 96 & 57 & 100 & 27 & P27 & 128 & 63 & P63 & 125 \\
\hline 48 & P4 8 & 728 & 207 & 232 & 2 & $\mathrm{P} 02$ & 123 & 26 & P26 & 121 \\
\hline 49 & P49 & 43 & 154 & 184 & 57 & P57 & 122 & 56 & P56 & 121 \\
\hline 50 & P50 & 236 & 319 & 152 & 44 & $\mathrm{P} 44$ & 119 & 62 & P62 & 119 \\
\hline 51 & P51 & 301 & 490 & 149 & 56 & P56 & 119 & 41 & P41 & 117 \\
\hline 52 & P52 & 216 & 368 & 116 & 47 & P47 & 96 & 8 & P08 & 114 \\
\hline 53 & P53 & 37 & 158 & 63 & 14 & P14 & 92 & 19 & P19 & 111 \\
\hline 54 & P54 & 239 & 352 & 109 & 20 & P20 & 87 & 37 & P37 & 96 \\
\hline 55 & P55 & 329 & 265 & 188 & 4 & P04 & 87 & 43 & P43 & 86 \\
\hline 56 & P56 & 119 & 121 & 75 & 10 & P10 & 83 & 35 & P35 & 86 \\
\hline 57 & P57 & 122 & 185 & 356 & 38 & P38 & 66 & 36 & P36 & 82 \\
\hline 58 & P58 & 449 & 451 & 191 & 45 & P4 5 & 45 & 7 & P07 & 76 \\
\hline 59 & P59 & 637 & 157 & 331 & 49 & P49 & 43 & 47 & P4 7 & 57 \\
\hline 60 & P60 & 206 & 266 & 211 & 63 & P63 & 41 & 29 & P29 & 41 \\
\hline 61 & P61 & 704 & 217 & 244 & 39 & P39 & 41 & 6 & P06 & 29 \\
\hline 62 & P62 & 23 & 119 & 0 & 53 & P53 & 37 & 44 & P44 & 19 \\
\hline 63 & P63 & 41 & 125 & 125 & 62 & P62 & 23 & 40 & P40 & 15 \\
\hline 64 & P64 & 270 & 288 & 163 & 11 & P11 & 0 & 42 & P42 & 0 \\
\hline
\end{tabular}




NATIONAL LIBRARY OF CANADA Bibliotheque nationale du Canada

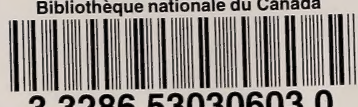

33286530306030 